\title{
POTENCIAL DA LOGÍSTICA FERROVIÁRIA PARA A MOVIMENTAÇÃO DE AÇÚCAR PARA EXPORTAÇÃO NO ESTADO DE SÃO PAULO: RECOMENDAÇÕES DE LOCALIZAÇÃO PARA ARMAZÉNS INTERMODAIS CONCENTRADORES DE CARGA
}

\author{
ANa Maria Kefalás Oliveira
}

\author{
Dissertação apresentada à Escola Superior de \\ Agricultura "Luiz de Queiroz", Universidade de São \\ Paulo, para obtenção do título de Mestre em \\ Ciências, Área de Concentração: Economia \\ Aplicada.
}

P I R A C I C A B A

Estado de São Paulo - Brasil

Maio - 2005 


\title{
POTENCIAL DA LOGÍSTICA FERROVIÁRIA PARA A MOVIMENTAÇÃO DE AÇÚCAR PARA EXPORTAÇÃO NO ESTADO DE SÃO PAULO: RECOMENDAÇÕES DE LOCALIZAÇÃO PARA ARMAZÉNS INTERMODAIS CONCENTRADORES DE CARGA
}

\author{
Ana Maria Kefalás Oliveira
}

Bacharel em Ciências Econômicas

Orientador: Prof. Dr. JOSÉ VICENTE CAIXETA FILHO

\begin{abstract}
Dissertação apresentada à Escola Superior de Agricultura "Luiz de Queiroz", Universidade de São Paulo, para obtenção do título de Mestre em Ciências, Área de Concentração: Economia Aplicada.
\end{abstract}

P I R A C I C A B A

Estado de São Paulo - Brasil

Maio - 2005 
Dados Internacionais de Catalogação na Publicação (CIP) DIVISÃO DE BIBLIOTECA E DOCUMENTAÇÃO - ESALQ/USP

Oliveira, Ana Maria Kefalás

Potencial da logística ferroviária para a a movimentação de açúcar para exportação no Estado de São Paulo: recomendações de localização para armazéns intermodais concentradores de carga / Ana Maria Kefalás Oliveira. - - Piracicaba, 2005.

166 p. : il.

Dissertação (mestrado) - - Escola Superior de Agricultura Luiz de Queiroz, 2005. Bibliografia.

1. Açúcar - Aspectos econômicos 2. Armazém 3. Custo econômico 4. Exportação 5. Indústria sucro-alcooleira 6. Logística (Administração) 7. Modelo matemático

CDD 338.476641

"Permitida a cópia total ou parcial deste documento, desde que citada a fonte - O autor" 
"Estejam vigilantes, mantenham-se firmes na fé, sejam homens de coragem, sejam fortes. Façam tudo com amor”.

(I Coríntios, 16:13-14) 


\section{AGRADECIMENTOS}

A Deus, pela vida, por suas bênçãos, pela família e pelas oportunidades que criou para que eu conquistasse mais este objetivo.

À minha família, minha estrutura. Aos meus pais Renato e Ilza, que me ensinaram o valor do amor, da honestidade, da luta, da dignidade e da responsabilidade. Compreenderam a distância e a ausência, acolheram sorrisos e lágrimas, muitas vezes renunciaram aos seus próprios sonhos para que eu pudesse realizar o meu, sem ao menos que eu soubesse. Apoiaram-me em todos os momentos e revestiram minha vida de amor e carinho. Minha eterna gratidão.

Aos meus irmãos, cunhados e sobrinhos, meus exemplos de luta, vitória, dedicação e afeição. À Aninha, ao Paulinho, à Lilica e à Mazinha, minhas fontes de força, amor, união e sonhos. Ao Ricardo, ao Sandro e à Tata, que agregaram felicidade à família. À Fernanda e ao Renato, pela ternura e pela alegria que transmitem.

Ao Léo, com quem, durante estes anos, compartilhei momentos de alegria, de angústias, de trabalho e de lazer. Agradeço pelo amor, pela dedicação, pela enorme paciência e pelas inúmeras palavras de incentivo. Apoio fundamental e inesquecível!

À Fê e à Cris, pela convivência diária fraterna em Piracicaba, repleta de boas conversas e compreensão. Aos colegas do mestrado, pela amizade, especialmente à Renata, à Mariúsa, à Leila, ao Paulo e à Lilian pela força e pelo companheirismo. À Eliza, pelo apoio e dedicação à elaboração dos mapas. A todos os amigos e parentes que me deram força, pelo carinho e pelas palavras de motivação. À equipe do ESALQ-LOG, muito obrigada pela compreensão e pela amizade.

Ao Professor Caixeta, a quem devo grande parte do meu aprendizado científico e pessoal nestes anos. Agradeço pela orientação impecável, pela motivação constante, pela 
amizade e confiança, pela paciência e dedicação. Além disso, agradeço as oportunidades oferecidas pelo ESALQ-LOG, muito importantes para meu crescimento intelectual e profissional.

Aos professores Márcia Azanha Moraes, Carlos Vian e José Maria Silveira pela atenção, pelas valiosas sugestões para este trabalho e pela amizade. A todos os professores do mestrado, pelo aprendizado.

Ao José Maria Ribeiro de Almeida, que despertou em mim o gosto pelo setor sucroalcooleiro e pelo transporte ferroviário. Agradeço as oportunidades oferecidas que propiciaram melhor conhecimento do tema que é foco deste trabalho.

Aos amigos da Brasil Ferrovias, pelo incentivo e pela amizade.

Ao Instituto de Economia da UNICAMP, pelas portas que abriu para minha vida.

A todos os funcionários da ESALQ, especialmente aos do departamento de Economia, por proporcionarem um ambiente tão agradável. À Maielli, à Ligiana, ao Álvaro, à Cida, à Dona Maria, ao André, ao Fernando, ao Flávio, à Helena, à Cris, à Márcia e ao Sr. Pedro, agradeço a convivência e a presteza. 
SUMÁRIO

Página

LISTA DE FIGURAS ................................................................................. viii

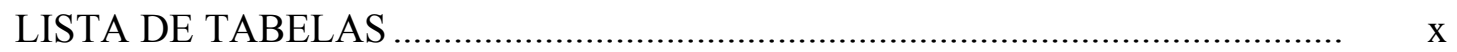

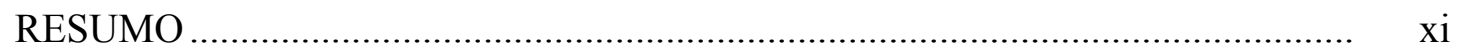

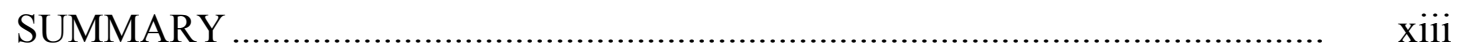

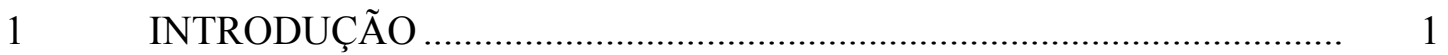

1.1 Considerações gerais............................................................................... 1

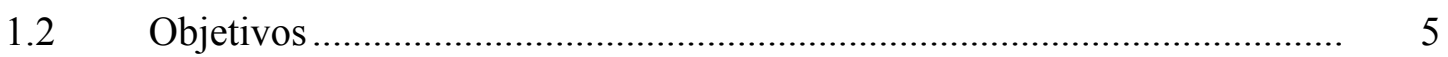

$1.3 \quad$ Estrutura do trabalho........................................................................ 5

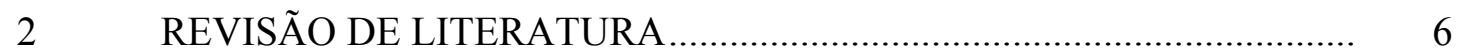

2.1 Caracterização do mercado de açúcar brasileiro............................................ 6

2.1.1 Histórico do setor sucroalcooleiro brasileiro ............................................... 6

2.1.2 A cultura da cana-de-açúcar no Brasil ...................................................... 20

2.1.3 O mercado açucareiro brasileiro .............................................................. 27

2.2 A logística no setor agrícola brasileiro ..................................................... 39

2.2.1 Especificidades das diferentes modalidades de transporte ......................... 40

2.2.2 Breve histórico da matriz de transporte de carga brasileira ......................... 43

2.2.3 Situação atual da matriz de transporte de carga brasileira ........................... 47

2.2.4 O transporte ferroviário de cargas no Brasil .............................................. 51

2.2.5 O armazenamento de produtos agrícolas ................................................. 65

3 MATERIAL E MÉTODOS ……......................................................... 71

3.1 Modelagem matemática de otimização em problemas de localização industrial 


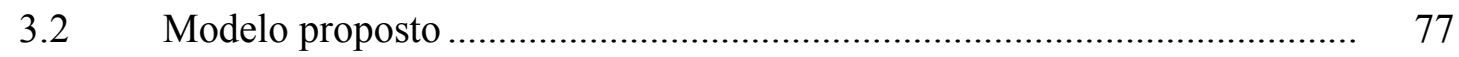

3.2.1 Representação diagramática................................................................ 78

3.2.2 Representação matemática...................................................................... 79

3.2.3 Cenários .................................................................................. 83

3.2.4 Especificação dos dados ...................................................................... 86

3.2.4.1 Localizações potenciais ........................................................................... 86

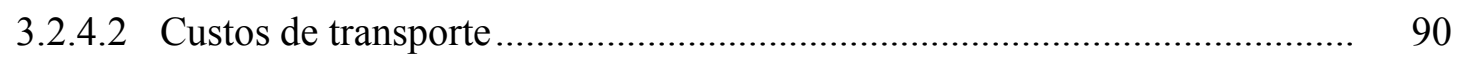

3.2.4.3 Oferta de açúcar para exportação em São Paulo........................................... 95

3.2.4.4 Demanda de açúcar ............................................................................. 99

3.2.4.5 Custo e capacidade de armazenamento................................................... 100

$4 \quad$ RESULTADOS E DISCUSSÃO ......................................................... 103

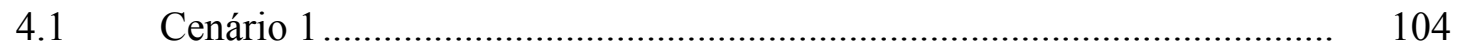

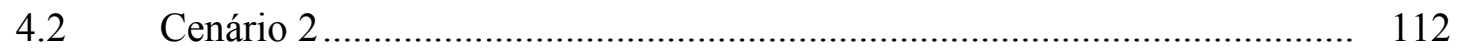

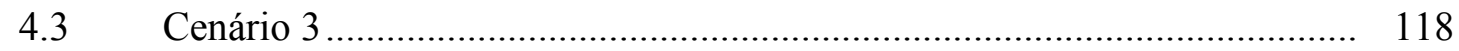

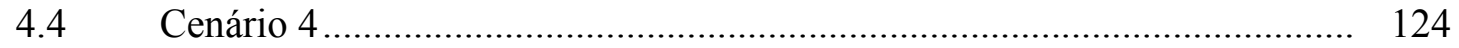

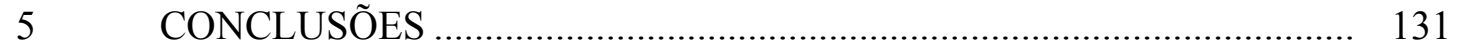

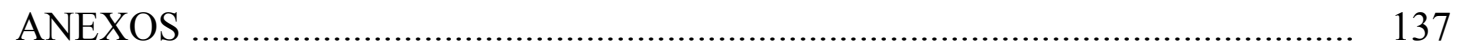

REFERÊNCIAS BIBLIOGRÁFICAS.......................................................... 144

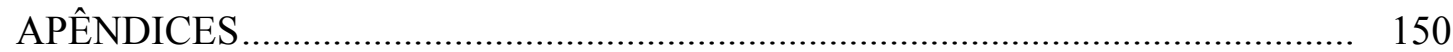




\section{LISTA DE FIGURAS}

Página

1 Produção de cana-de-açúcar no Brasil ................................................................. 22

2 Participação dos estados brasileiros na produção de cana-de-açúcar, safra $2003 / 2004$

3 Produção mundial de açúcar, 1989/1990 a 2003/2004 _..................................... 28

4 Produção mundial de açúcar, 1989/1990 a 2003/2004 _...................................... 29

5 Evolução da produção de açúcar no Brasil .......................................................... 29

6 Participação dos estados na produção nacional de açúcar, safra 2003/2004 ...... 30

7 Participação das regiões Norte-Nordeste e Centro-Sul na produção de açúcar do Brasil, 1990/1991 a 2003/2004 _...................................................................... 30

8 Produção de açúcar no Brasil, 1990/1991 a 2003/2004 ……............................. 31

9 Exportação mundial de açúcar, 1990 a 2004 .................................................... 33

10 Participação do açúcar brasileiro nas exportações mundiais, 1989/1990 a

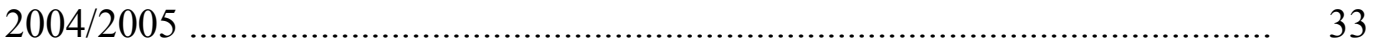

11 Exportações brasileiras de açúcar, 1996 a 2003 ................................................ 34

12 Percentual da produção de açúcar brasileiro destinado ao mercado interno e à exportação, 1996/1997 a 2003/2004 _............................................................... 36

13 Exportações acumuladas de açúcar ...................................................................... 38

14 Participação modal no transporte de cargas, 2003 .............................................. 48

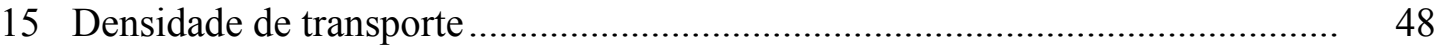

16 Malha rodoviária brasileira, 2003 ................................................................. 49

17 Círculo vicioso do transporte rodoviário .............................................................. 51

18 Malha Ferroviária brasileira, 2003 …............................................................ 55

19 Investimentos na malha nacional, em R\$ milhões ............................................. 56 
20 Produção ferroviária das ferrovias privatizadas, em bilhões de toneladasquilômetro útil (TKU) ................................................................................. 57

21 Produção Brasileira de vagões ........................................................................ 60

22 Área de atuação da Brasil Ferrovias ................................................................. 63

23 Volume anual de açúcar operado pela Brasil Ferrovias..................................... 64

24 Distribuição da capacidade estática por entidade ............................................. 67

25 Distribuição da capacidade por localização ....................................................... 68

26 Canais de comercialização .............................................................................. 69

27 Representação diagramática do modelo de localização ótima............................ 79

28 Áreas de influência dos municípios considerados como possíveis locais para instalação de armazéns..................................................................................... 89

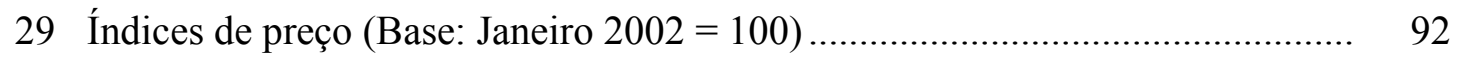

30 Sazonalidade do frete rodoviário de açúcar a granel com origem no estado de São Paulo e destino a Santos, 2002 a 2004 ..

31 Variação sazonal do frete rodoviário de açúcar a granel com origem no estado de São Paulo e destino a Santos, 2002 a 2004, medida em relação ao frete médio.

32 Sazonalidade dos fretes de açúcar a granel praticados em São Paulo com destino ao Porto de Santos e das exportações brasileiras.

33 Fretes ferroviários praticados no estado de São Paulo, em valores de junho de 2004 para dados de jan/02 a jun/04 e valores correntes para jun/04 a dez/04 ....

34 Configuração dos fluxos ótimos de açúcar - CENÁRIO 1

35 Configuração dos fluxos ótimos de açúcar - CENÁRIO 2

36 Configuração dos fluxos ótimos de açúcar-CENÁRIO 3

37 Configuração dos fluxos ótimos de açúcar - CENÁRIO 4 


\section{LISTA DE TABELAS}

Página

1 Desempenho das exportações do agronegócio brasileiro em 2003.................... 3

2 Quantidade produzida, área plantada e produtividade média, 2002 ................. 24

3 Produção de açúcar pelos estados brasileiros, 1996/1997 a 2003/2004, em mil

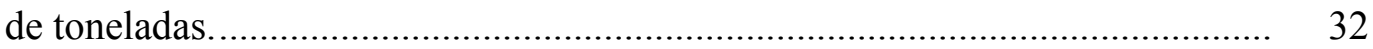

4 Exportação de açúcar por porto, em mil toneladas ............................................. 37

5 Características operacionais relativas por modal de transporte .......................... 42

6 Concessões resultantes da privatização da RFFSA............................................. 54

7 Evolução da capacidade estática de armazenagem no Brasil de 1978 a 2002 ... 66

8 Quantidade e capacidade estática dos armazéns cadastrados na CONAB, por espécie e região, posição agosto / 2004 ............................................................. 67

9 Diferenciação entre os cenários .................................................................... 84

10 Usinas consideradas no modelo matemático e suas produções de açúcar,

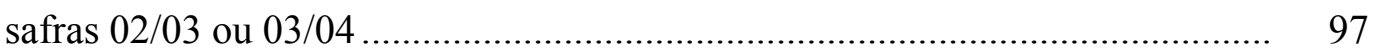

11 Volume das exportações de açúcar de São Paulo, por principais portos, 2002

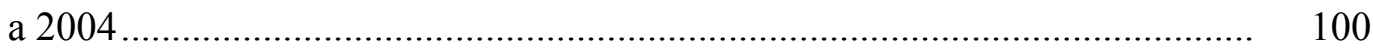

12 Momentos de transporte utilizados para obtenção do frete................................. 141

13 Índices de preço utilizado para levar valores médios de frete para base junho/2004 


\title{
POTENCIAL DA LOGÍSTICA FERROVIÁRIA PARA A MOVIMENTAÇÃO DE AÇÚCAR PARA EXPORTAÇÃO NO ESTADO DE SÃO PAULO: RECOMENDAÇÕES DE LOCALIZAÇÃO PARA ARMAZÉNS INTERMODAIS CONCENTRADORES DE CARGA
}

\author{
Autora: ANA MARIA KEFALÁS OLIVEIRA \\ Orientador: Prof. Dr. JOSÉ VICENTE CAIXETA FILHO
}

\section{RESUMO}

O setor sucroalcooleiro brasileiro é o altamente competitivo internacionalmente. O país ocupa o primeiro lugar no ranking mundial da produção e da exportação do de açúcar. Na década de 90, este setor passou pelo processo de desregulamentação, após um período de quase 60 anos sob proteção do Estado. Este processo trouxe novos e grandes desafios para o setor. Ocorreram mudanças significativas na produção, na comercialização e na mentalidade do setor a fim de se adequarem às condições de livre mercado. Novas estratégias precisaram ser criadas para superar os problemas advindos do afastamento do Estado. A exigência de constantes aumentos de competitividade implicou a necessidade de otimização da alocação de recursos. A estratégia de otimização da logística do açúcar surge então como uma forma de buscar uma melhoria ou pelo menos a manutenção das margens de comercialização da commodity. O transporte ferroviário de carga brasileiro, relegado, durante muitos anos, a segundo plano, passa pelo processo de privatização e começa a mostrar sua importância e suas vantagens, principalmente para o transporte de cargas de baixo valor 
agregado e grandes volumes, como é o caso do açúcar, devido a suas especificidades de alto custo fixo e custo variável relativamente baixo. A alternativa intermodal, que neste caso inclui o transporte rodoviário do produto até um centro coletor de carga e o transporte ferroviário deste centro até o destino final, passa a se tornar economicamente interessante. Este trabalho está focado na utilização do transporte ferroviário para escoamento do açúcar a granel produzido no estado de São Paulo para exportação e tem o objetivo de analisar o aumento da importância das estratégias logísticas adotadas pelo setor sucroalcooleiro no período pós-desregulamentação e verificar a localização ótima para armazéns intermodais concentradores de carga (açúcar) no estado de São Paulo. Foi proposto um modelo matemático de programação mista que teve o objetivo de minimizar o custo logístico total e verificar a configuração espacial e os tamanhos ótimos de armazéns coletores de açúcar para viabilização do transporte ferroviário em São Paulo. Foram elaborados quatro cenários e os resultados apontam para a alta competitividade da alternativa intermodal em comparação à alternativa que envolve o transporte rodoviário da usina diretamente ao porto indicando, desta forma, espaço para aumento do market share da ferrovia na movimentação de açúcar para exportação. Quanto aos locais escolhidos para os armazéns, os resultados apresentaram uma convergência para instalação de grandes unidades em Araçatuba, Araraquara, Barretos, Ribeirão Preto, Pradópolis e Santa Adélia. Todos os cenários também consideraram a presença de armazéns em Tupã, Bauru e Palmital, porém, em alguns casos, com capacidades inferiores. A alocação ótima obtida em alguns cenários não considerou a indicação de Fernandópolis como economicamente viável, mas há que se ressaltar que este trabalho está limitado ao estado de São Paulo e, possivelmente, usinas mineiras poderiam dar sustentação à viabilização desta localidade. Boituva, o município considerado mais próximo do porto, apenas tornou-se viável em um dos cenários indicando a maior competitividade do transporte rodoviário em distâncias curtas. 


\title{
POTENCIAL DA LOGÍSTICA FERROVIÁRIA PARA A MOVIMENTAÇÃO DE AÇÚCAR PARA EXPORTAÇÃO NO ESTADO DE SÃO PAULO: RECOMENDAÇÕES DE LOCALIZAÇÃO PARA ARMAZÉNS INTERMODAIS CONCENTRADORES DE CARGA
}

\author{
Author: ANA MARIA KEFALÁS OLIVEIRA \\ Advisor: Prof. Dr. JOSÉ VICENTE CAIXETA FILHO
}

\section{SUMMARY}

Brazilian sugar and alcohol sector is highly competitive in the international market. The country occupies the first place in world-wide ranking of sugar production and exportation. In the 90's, this sector passed through the deregulation process, after a period of almost 60 years under protection of the State. This process brought new and great challenges for the sector. There were significant changes in the production, the commercialization and the mentality of the sector in order to be adjusted to the conditions of a free market. New strategies had to be created to surpass the problems of the State withdrawal. The requirement of constant increases of competitiveness implied the necessity of finding the best resources allocation. The strategy of optimization of the sugar logistic appears then as one form of improvement or, at least, of the maintenance of the commodity commercialization margin. Brazilian railway cargo transportation was relegated to a second plan during many years. With its privatization, it started to show its importance and its advantages, mainly for the low aggregate value loads with great 
volumes, as it is the case of the sugar, because of its high fixed cost and relatively low variable costs. The intermodal alternative that, in this case, includes the road transport of the product to a collecting load center and the railway transport of this center up to the final destination, become economically interesting. The focus of this work is the use of the railway transport of bulk sugar produced in the state of São Paulo for exportation and has the objective to analyze the increase of the importance of the logistic strategies adopted by the sugar sector in the after-deregulation period and to verify the best localization for concentrative intermodal load warehouses (sugar) in the state of São Paulo. A mixed integer programming was considered with the objective of minimizing the total logistic costs and to verify the optimal space configuration and the best sizes of collecting sugar warehouses in São Paulo that would make possible the use of railway transportation. Four scenarios had been elaborated and the results point out the high competitiveness of the intermodal alternative in comparison to the road transport alternative directly to the port, indicating space for increase of railway market share in the sugar for exportation transportation. Considering the places chosen for the warehouses, the results converged for installation of large units in Araçatuba, Araraquara, Barretos, Ribeirão Preto, Pradópolis and Santa Adélia. All the scenarios had also considered the presence of warehouses in Tupã, Bauru and Palmital; however, in some cases, with inferior capacities. The best allocation achieved in some scenarios did not consider as economically viable a warehouse located in Fernandópolis, but one has to stand out that this work is limited to the state of São Paulo and, possibly, plants of Minas Gerais could give sustentation to make it viable. Boituva, the closest city to the port, only became viable in one of the scenarios indicating higher competitiveness of the road transport in short distances. 


\section{INTRODUÇÃO}

\subsection{Considerações gerais}

O dinamismo do agronegócio ${ }^{1}$ tem sido considerado um dos aspectos mais relevantes da economia brasileira nos últimos anos. O produto interno bruto (PIB) agropecuário, calculado pelo Instituto Brasileiro de Geografia e Estatística (IBGE), tem apresentado taxas de crescimento elevadas, fato que tem chamado a atenção pelo comportamento distinto dos outros componentes do PIB brasileiro. Entre 1990 e 2002, o PIB total da economia cresceu a uma taxa anual de $2,71 \%$, enquanto que o PIB agropecuário cresceu a uma taxa de 3,18\% ao ano. Nos períodos 1995 a 2002, 1997 a 2002 e 1999 a 2002, o PIB total cresceu a taxas anuais de 1,97\%, 1,86\%, 2,32\% enquanto o PIB agropecuário cresceu 3,49\%, 4,57\% e 4,29\% ao ano, respectivamente (Gasques \& Bastos, 2003).

O agronegócio brasileiro já é responsável por mais de um terço do PIB nacional. De acordo com estudos da Confederação da Agricultura e Pecuária do Brasil (CNA) em parceria com o Centro de Estudos Avançados em Economia Aplicada da Universidade de São Paulo (CEPEA, 2004), o PIB do agronegócio ${ }^{2}$ em 2003 alcançou R\$ 508,27 bilhões, valor que representa cerca de 34\% do PIB nominal do Brasil naquele ano.

1 “... o agronegócio é visto como a cadeia produtiva que envolve desde a fabricação de insumos, passando pela produção nos estabelecimentos agropecuários e pela sua transformação, até o seu consumo" (Gasques e Bastos, 2003).

2 “O cálculo do PIB do Agronegócio incorpora, além do setor primário agropecuário, o setor a montante (parque industrial que fornece bens de capital e insumos para o campo) e o setor a jusante (rede armazenadora, transporte, processamento, industrialização e distribuição)" http://www.cepea.esalq.usp.br/pib/ (10 maio 2004) 
Simultaneamente ao crescimento econômico do agronegócio, cresce também a área plantada em direção a regiões não tradicionais no setor, mostrando um importante rearranjo espacial na agricultura brasileira. O agronegócio está ocupando novas áreas, principalmente em direção ao Centro-Oeste e ao Norte do país, calcado em modernas tecnologias de produção. A este movimento da produção agrícola, segue o dos fornecedores de matérias-primas, armazenadores e indústrias que se instalam em regiões próximas às áreas de produção em busca de maior competitividade, principalmente internacional, através da racionalização dos custos logísticos.

Atualmente, o agronegócio é o principal responsável pelos superávits na balança comercial brasileira e, dentre os principais produtos que contribuem com este saldo positivo está o açúcar que, juntamente com produtos do complexo soja, carnes, produtos florestais, café, tabaco e suco de laranja, dentre outros, apresenta-se como um importante produto na pauta de exportações brasileiras. A Tabela 1 mostra o desempenho das exportações do agronegócio brasileiro em 2003, especificando o volume de recursos obtidos com a exportação desses produtos, a participação e o ranking de cada produto brasileiro no mercado internacional e a taxa anual média de crescimento das exportações entre 1990 e 2003.

Observa-se que o volume de açúcar exportado vem crescendo a taxas elevadas e, em 2003, participou com cerca de $30 \%$ do volume negociado internacionalmente e gerou mais de US\$ 2 bilhões para a balança comercial. 
Tabela 1. Desempenho das exportações do agronegócio brasileiro em 2003

\begin{tabular}{lcccc}
\hline \multicolumn{1}{c}{ Produto } & $\begin{array}{c}\text { Valor exportações } \\
\text { (US\$ Milhões) }\end{array}$ & $\begin{array}{c}\text { Brasil / Mundo } \\
\text { Participação } \\
\text { Brasil / Mundo }\end{array}$ & $\begin{array}{c}\text { Taxa anual de } \\
\text { crescimento (1990 } \\
\text { - 2003) }\end{array}$ \\
\hline Soja - grão & 4.290 & $38 \%$ & 1 & $17 \%$ \\
Soja - farelo & 2.602 & $34 \%$ & 2 & $4 \%$ \\
Açúcar & 2.140 & $29 \%$ & 1 & $18 \%$ \\
Frango & 1.709 & $29 \%$ & 2 & $13 \%$ \\
Carne Bovina & 1.538 & $20 \%$ & 1 & $9 \%$ \\
Café & 1.302 & $29 \%$ & 1 & $3 \%$ \\
Soja - óleo & 1.232 & $28 \%$ & 2 & $9 \%$ \\
Suco de laranja & 1.192 & $82 \%$ & 1 & $1 \%$ \\
Tabaco & 1.052 & $23 \%$ & 1 & $7 \%$ \\
Carne suína & 542 & $16 \%$ & 4 & $27 \%$ \\
Milho & 369 & $4 \%$ & 4 & $53 \%$ \\
Algodão & 189 & $5 \%$ & 4 & $12 \%$ \\
Total Agrícola & 21.281 & $3,8 \%$ & 3 & $6,4 \%$ \\
\hline
\end{tabular}

Fonte: Jank (2004)

A cadeia agroindustrial sucroalcooleira brasileira diferencia-se dos demais países produtores de açúcar de cana por produzir em grande escala tanto açúcar como álcool. Na safra 2002/2003, cerca de 280 usinas operaram no país, produzindo aproximadamente 20,2 milhões de toneladas de açúcar e 12,4 bilhões de litros de álcool. O Centro-Sul, com 211 unidades produtoras (74\% do total), foi responsável por 89\% da produção de álcool e $82 \%$ da produção de açúcar. Segundo o United States Department of Agriculture (USDA) (2004), nessa safra a produção e exportação brasileiras representaram, respectivamente, $16 \%$ e $30 \%$ do total mundial. Neste período o Brasil exportou 14 milhões de toneladas de açúcar, ou seja, cerca de $60 \%$ da quantidade produzida. 
A história do setor sucroalcooleiro brasileiro foi marcada pela intervenção governamental que visava o equilíbrio da produção e dos preços de cana-de-açúcar, açúcar e álcool. Somente nos anos 90, quando ocorre uma redefinição do papel do estado na economia do país, acontece a desregulamentação do setor que provocou mudanças significativas no que se refere à produção, à comercialização e à mentalidade do setor a fim de se adequarem às condições de livre mercado.

A exigência de constantes aumentos de competitividade para superar os problemas advindos do afastamento do Estado implicou a necessidade de otimização da alocação de recursos. Novas estratégias tiveram que ser adotadas, dentre elas, a melhoria na logística, fator fundamental tanto para a qualidade do nível de serviço prestado aos clientes quanto para a redução de custos, principalmente por se tratar de commodity agrícola, cujo preço é ditado pelo mercado internacional e, portanto, a margem de comercialização será tanto maior quanto menores forem os custos de produção e de comercialização.

A utilização do modal ferroviário na logística de movimentação de açúcar para exportação pode se revelar, em muitos casos, como uma alternativa interessante em função de suas características de altos custos fixos e custos variáveis baixos, que possibilitam o surgimento de economias de escala quando os volumes de carga a serem embarcados e a distância percorrida forem relativamente altos.

Além disso, o governo atual tem dado sinais (principalmente através do Plano de Revitalização das Ferrovias) de que está disposto a realizar investimentos nesse setor, juntamente com os concessionários. Entretanto, há que se considerar uma restrição para inclusão do modal ferroviário nas estratégias logísticas das empresas: ela implica a necessidade de concentração de carga em um determinado local para que o transporte seja eficiente, uma vez que flexibilidade não é característica comum do transporte ferroviário, aspecto este mais intrínseco à modalidade rodoviária, que possibilita atender os clientes na porta da fábrica e carregar quantidades relativamente pequenas. A atual demanda do açúcar por transporte ferroviário e a necessidade de construção de armazéns 
concentradores de carga são objetos de estudo deste trabalho, o qual será detalhado na seção seguinte.

\subsection{Objetivos}

O objetivo principal deste trabalho é analisar o aumento da importância das estratégias logísticas adotadas pelo setor sucroalcooleiro no período pósdesregulamentação e verificar a localização ótima para armazéns intermodais concentradores de carga (açúcar) no estado de São Paulo. Este trabalho está focado na utilização do transporte ferroviário para escoamento do açúcar a granel para exportação, já que esta modalidade apresenta características bastante interessantes para produtos como o açúcar. Especificamente, pretende-se: 1) analisar o desenvolvimento histórico do setor sucroalcooleiro com foco nas implicações da desregulamentação do setor que exigiram a adoção de novas estratégias para enfrentar as dificuldades advindas do afastamento do Estado; 2) descrever a situação atual do mercado de açúcar no país; 3) analisar a evolução do transporte de carga no Brasil, dando ênfase à modalidade ferroviária, e mostrar o papel da armazenagem na logística do setor; 4) propor e aplicar um modelo matemático de otimização para a localização de armazém intermodal de açúcar para o estado de São Paulo, considerando a capacidade de produção das usinas e os custos de movimentação envolvidos na exportação do açúcar.

\subsection{Estrutura do trabalho}

Além desta introdução, o trabalho será constituído por mais quatro capítulos. O capítulo 2 é composto por uma revisão de literatura sobre o setor sucroalcooleiro brasileiro e sobre o setor ferroviário de carga. A metodologia para alcançar os objetivos deste trabalho está especificada no capítulo 3. O capítulo 4 apresenta e discute os resultados do trabalho, os quais são sumarizados no quinto capítulo. 


\section{REVISÃO DE LITERATURA}

\subsection{Caracterização do mercado de açúcar brasileiro}

\subsubsection{Histórico do setor sucroalcooleiro brasileiro}

O açúcar nordestino foi, por quatro séculos, o carro-chefe da agroindústria brasileira. Segundo Ramos \& Belik (1989), o clima e a proximidade do mercado europeu proporcionaram um papel de destaque para o açúcar produzido no Nordeste e para sua exportação. Os autores afirmam que foi a partir do século XVIII que a produção paulista de açúcar e aguardente passa a ser expressiva; ela surgiu no litoral para atender à demanda do mercado aberto pela mineração nas Gerais e em Goiás e aos poucos seguia para o interior. Em meados do século XIX, São Paulo já se destacava na produção nacional de açúcar, porém não concorria no mercado externo com o açúcar nordestino devido à sua baixa qualidade. Foi com a crise do café, na década de 20, que a área ocupada por esta cultura foi significativamente substituída pela cana-de-açúcar que iniciou seu importante papel na economia paulista.

O Nordeste passou a enfrentar a concorrência do açúcar paulista, das Antilhas e da Europa. Neste momento, o mundo presenciava uma superprodução e queda de preços do açúcar, agravados pela crise de 1929 que fez encolher o mercado internacional de açúcar e fez os empresários, principalmente os nordestinos, defenderem a criação de um mecanismo de controle de preços e quantidades. Inicia-se aí o processo de intervenção com a criação, em 1933, do Instituto do Açúcar e do Álcool (IAA). 
A cadeia agroindustrial sucroalcooleira foi altamente regulada pelo Estado desde a década de 30 até os anos 90. O governo determinava cotas de produção de açúcar e álcool para cada usina, estabelecia preços da cana-de-açúcar, do açúcar e do álcool além de controlar a comercialização dos produtos. A intervenção estatal foi importante na conciliação dos interesses dos agentes do complexo, bastante fragmentados.

O processo intervencionista, conforme ressalta Moraes (2000), está fundamentado no fato de que o setor sucroalcooleiro sempre viveu ciclos de superprodução e o controle de diversas variáveis do setor objetivava preservar o equilíbrio entre produção e consumo, utilizando-se de dois instrumentos básicos: os planos de safra e as políticas de preço e crédito. Vian (2003) salienta a importância dos instrumentos de intervenção do Estado utilizados para amenizar as recorrentes crises do complexo canavieiro, organizando os agentes e minimizando os conflitos regionais.

O IAA foi criado para regular as relações na cadeia produtiva e defender os produtos brasileiros no mercado externo. Neste período, seu objetivo era "resolver o problema da superprodução da agroindústria açucareira, através do planejamento e controle anual da produção adequando-a às necessidades de consumo interno e externo. Além disso, pretendia fomentar a produção de álcool no país” (Moraes, 2000, p.46). O IAA determinava a produção de álcool e açúcar de cada usina com base nos estoques e na expectativa da safra seguinte.

Vian (2003, p.61) afirma que "as políticas de intervenção no setor foram criadas e implementadas e ou alteradas, quase sempre, em momentos de crise econômica". A criação do IAA, por exemplo, é resultado da crise da crise mundial de superprodução e de desentendimentos regionais internos. $\mathrm{O}$ autor mostra que as ações estatais eram, na maioria das vezes, tomadas de acordo com os interesses dos empresários do setor, proporcionando compensações para os prejudicados, evitando críticas e oposições. 
Em 1941 foi instituído o Estatuto da Lavoura Canavieira (ELC), legislação corporativista gerenciada pelo IAA (controle e fiscalização) a qual foi considerada um avanço para a coordenação da cadeia, conforme destacam Ramos \& Belik (1989). O estatuto, além de legalizar a figura do fornecedor de cana, estabeleceu condições para o fornecimento e critérios para fixação do preço da cana-de-açúcar (Moraes, 2000).

Com o advento da II Guerra Mundial, houve uma escassez de derivados de petróleo no mercado internacional, o que valorizou o álcool anidro como um produto estratégico para o Brasil, cujo preço mínimo passou a ser garantido pelo governo brasileiro que também fixou a mistura, em 1941, de 20\% de álcool anidro na gasolina.

Segundo Szmerecsányi (1979) citado por Ramos \& Belik (1989), a guerra também trouxe conseqüências para o mercado de açúcar: as exportações e o comércio de cabotagem inter-regiões do Brasil sofreram colapso, o transporte marítimo de açúcar entre o Nordeste e o Centro-Sul cessou e acabou dividindo o país em duas áreas: o Nordeste com superprodução de açúcar e o Centro-Sul, com falta de produto.

Estes riscos advindos da guerra, aliados à defasagem entre produção e consumo no Centro-Sul, fizeram com que o governo brasileiro aumentasse a cota de produção destinada às unidades produtoras do Centro-Sul. Foi neste período que houve uma mudança da configuração espacial da produção açucareira, deslocando o eixo de produção do Nordeste para o Centro-Sul do país.

Conforme salienta Moraes (2000), com o fim da II Guerra Mundial, a tendência de aumento de produção persistiu e a pressão dos usineiros paulistas resultou em uma revisão geral das cotas de produção que, a partir desse momento, passa a ser baseada no déficit de produção e consumo de cada estado, o que incentivou o aumento de unidades produtoras em São Paulo. 
No final dos anos 40 já se percebia um aumento na quantidade e na qualidade das usinas paulistas. Pina ${ }^{3}$ (1972:41, citado por Moraes, 2000, p.51) ressalta que a revisão geral das cotas beneficiou o produtor do Sul “... graças às (suas) condições peculiares, como sejam: maior capacidade financeira, mercado em posição vantajosa, parque industrial moderno com eficientes instalações e condições agrícolas favoráveis. Quase totalmente reverso do Nordeste...”. Os custos de produção de açúcar no Nordeste (maiores que o do Centro-Sul) e a distância do mercado paulistano favoreceram o aumento da produção de açúcar em São Paulo.

A década de 50 foi marcada por vários conflitos de interesses entre produtores do Nordeste e do Centro-Sul do país perante o governo federal no que tange ao estabelecimento de preços. Segundo Szmrecsányi (1979) ${ }^{4}$, citado por Moraes (2000), em 1951, foi instituída uma sobretaxa aos produtores do Centro-Sul que seriam revertidas para os produtores nordestinos como forma de compensação de fretes para permitir equivalência de preços nos diversos centros consumidores, financiamento da produção, expansão do parque sucroalcooleiro e custeio de insumos modernos.

Foi na década de 50 também que surgiu o cooperativismo no setor, "como uma forma de organizar as usinas e balancear o poder dos comerciantes" (Vian, 2003, p.78) que se apoderavam de parcela significativa de lucro da comercialização. No início dos anos 50, a Cooperativa Piracicaba de Usinas de Açúcar e Álcool do Estado de São Paulo e a Cooperativa de Usineiros do Oeste de São Paulo foram fundadas com intuito de comercializar a produção das cooperadas e gerenciar os estoques, além de funcionar como centro de compra de insumos e prestar assistência administrativa, fiscal e técnica aos cooperados e manter centros de pesquisa. Em 1959, essas duas cooperativas uniramse à Refinaria Paulista e criaram a Cooperativa Central de Produtores de Açúcar e Álcool de São Paulo, a Copersucar, que se tornou o agente comercial e financiador dos

\footnotetext{
${ }^{3}$ PINA, H. A agroindústria açucareira e sua legislação. Rio de Janeiro: APEC,1972.364p.

4 SZMRECSÁNYI, T. O planejamento da agroindústria canavieira do Brasil (1930-1975). São Paulo: Hucitec / Universidade Estadual de Campinas, 1979. 540p.
} 
usineiros paulistas. Este foi um caso de união e coordenação do setor bem-sucedido (Vian, 2003).

Em 1965, a sistemática de determinação de preços muda: os preços passaram a basear-se nos custos de produção de cada região. Isto implicava a necessidade de não permitir comércio entre as regiões, pois o açúcar do Centro-Sul conseguia chegar no mercado nordestino a preços competitivos. Moraes (2000) afirma que esta sistemática vigorou até antes da liberação dos preços ocorridos em fevereiro de 1999.

Na década de 60, a situação do mercado externo se altera favoravelmente ao Brasil: o embargo norte-americano às exportações cubanas (devido à revolução) abriu uma oportunidade para o açúcar brasileiro. Ramos \& Belik (1989; p.204) afirmam que “em 1965, o Brasil já exportava $15 \%$ da sua produção, contribuindo com 3,5\% do comércio mundial de açúcar. Nossa produção voltava, assim, ao mercado mundial agora liderada pelos usineiros paulistas".

Neste contexto, o IAA adota política expansionista e passa a financiar a construção de novas usinas no Centro-Sul, redistribui cotas de exportação e, com o aumento das exportações, arrecada recursos para financiar a modernização do setor. Surge então o "Plano de Expansão da Agroindústria Açucareira Nacional”, com objetivo de aumentar a produção através de construção de novas usinas e aumentar a produtividade agrícola e industrial do setor a fim de reduzir custos de produção (Vian, 2003).

Em 1964, aparecem sintomas de nova crise de superprodução de açúcar, os preços caem no Mercado Livre Mundial ${ }^{5}$ e os estoques aumentam. Moraes (2000) indica que os fatores que geraram a crise foram as excelentes condições climáticas, a

\footnotetext{
${ }^{5}$ O Mercado Livre Mundial de açúcar corresponde a cerca de $80 \%$ do volume transacionado internacionalmente. Os $20 \%$ restantes correspondem ao comércio intra-bloco da União Européia (UE) $(8,3 \%)$, às exportações de Cuba para Rússia $(5 \%)$, às importações preferenciais da UE $(4,1 \%)$ e às importações dos EUA (2,8\%).

JANK, M.S. Publicações. http://www.iconebrasil.org.br/images/publicacoes/ICONE/ Sugar\%20Dinner_to_BBA.pdf (12 dez. 2004)
} 
incapacidade de intervenção do IAA - dados os recursos disponíveis - e o erro de avaliação das tendências do mercado internacional.

A autora afirma ainda que após a crise, o governo Costa e Silva decide recuperar a agroindústria canavieira, estabelecendo medidas de longo prazo como construção de terminais e financiamento de projetos de racionalização do setor durante toda a década de 70. Dentro de um contexto mais geral de incentivo às exportações do país, a exportação de açúcar passa a ter caráter permanente a partir do final da década de 60.

A década de 70, conforme Moraes (2000), caracterizou-se pelos fomentos à exportação e por programas de melhoria de produtividade e de racionalização da produção. Em 1971, as fusões, incorporações e relocações de usinas foram incentivadas o que, segundo a autora, foi um estímulo à concentração de mercado.

Neste ponto, uma observação é relevante: Ramos \& Belik (1989) definiram o processo de concentração técnica do setor como sendo aquela que surge devido a características peculiares à cana-de-açúcar. Devido a suas características físico-químicas que indicam que, após o seu corte, a cana-de-açúcar passa a diminuir seu teor de sacarose e, com a queima, passa também a perder peso e, além disso, a baixa relação valor/peso da cana tem impacto negativo no seu transporte. Essas características fazem com que as terras mais próximas das indústrias sejam mais valorizadas e estas, muitas vezes, pertencem às próprias usinas. A este processo de concentração técnica seguiu-se uma concentração econômica e uma centralização de capitais, com a absorção dos pequenos capitais pelos maiores.

Ramos \& Belik (1989) afirmam que a década de 60 inicia-se com a hegemonia de quatro ou cinco grupos familiares que administravam mais de $50 \%$ da produção de açúcar e álcool em São Paulo. No Nordeste não foi diferente, também houve uma concentração bastante elevada. Com a justificativa da necessidade de aumentar a competitividade do Brasil no mercado internacional, o IAA incentiva fusões e incorporações de usinas e fazendas. 
É na década de 70 que o Brasil torna-se o primeiro produtor e o segundo exportador mundial de açúcar. Neste período, o Brasil passou a participar com cerca de 12\% no mercado mundial (Ramos \& Belik, 1989). Entre o final de 1971 e o início de 1972 os estoques mundiais caíram e o preço praticamente dobrou. Segundo Moraes (2000), o aumento das exportações neste período gerou fundos para o IAA, que pôde expandir sua atuação através de políticas de modernização, subsídios de preços ao consumidor, incentivo a fusões, a aquisições e a mudanças de localização das usinas e ainda pôde proporcionar financiamentos em condições favoráveis.

Apesar disso, existiam discordâncias entre os agentes do setor quanto a essas políticas. Os principais pontos de discordância diziam respeito à distribuição de cotas e aos preços praticados, que eram menores que os custos de produção. Gomes ${ }^{6}$ (1979, citado por Moraes, 2000) ressalta que a expansão da agroindústria canavieira somente era possível devido a incentivos através de créditos e subsídios: prazos prolongados para pagamentos, preços e juros subsidiados, não aplicação de correção monetária, estas eram as políticas paternalistas que, segundo o autor, tornava possível o negócio sucroalcooleiro no Brasil.

Em meados da década de 70, houve uma queda do preço do açúcar, queda do consumo dos importadores (fechamento temporário do mercado preferencial americano) e previsões de aumento da oferta mundial devido à recuperação da produção européia e ao aumento da capacidade de produção de vários países produtores, o que acabou reduzindo os recursos destinados ao IAA e enfraquecendo-o.

Neste período, o alto preço do petróleo, agravado pelo endividamento externo crescente do Brasil (conseqüência também do próprio aumento do petróleo), fez ressurgir o interesse pela produção de álcool tanto pelo governo, para equilibrar o balanço de pagamentos, quanto pelos usineiros, pois estes haviam expandindo suas capacidades de produção para atender ao mercado crescente de açúcar, mas que neste

${ }^{6}$ GOMES, G.M. Caráter e conseqüências da intervenção estatal no setor açucareiro do Brasil: 1933/1978. Estudos Econômicos, v.9, n.3, p.123-150, set./dez. 1979. 
momento, estava em declínio. "Desta forma, a situação conjunta destes dois mercados açúcar e petróleo - acabou determinando a política nacional do álcool” (Moraes, 2000, p.62).

Dentre uma série de medidas tomadas pelo governo Geisel com o objetivo de reduzir o déficit do balanço de pagamentos, estava o Programa Nacional do Álcool (Proálcool). Os preços declinantes do açúcar no mercado internacional e a capacidade ociosa das usinas (que haviam ampliado suas capacidades baseadas numa expectativa errônea do crescimento da demanda mundial) acabaram por se tornarem um incentivo ao crescimento da produção de álcool.

Vian (2003) afirma que a criação do Proálcool foi mais um exemplo da força política dos usineiros no Brasil. O projeto inicial do governo, segundo o autor, incluía outros produtos para a fabricação do álcool tais como mandioca e sorgo sacarino, porém a capacidade ociosa das usinas, a alta produtividade agrícola e industrial da cana, a capacidade de geração de empregos e a possibilidade de obtenção de álcool em curto prazo foram os argumentos fortes utilizados pelos usineiros para fazerem com que a cana fosse, na prática, a única matéria-prima do álcool.

A oficialização do Proálcool se deu em 1975 com o objetivo de economizar divisas, diminuir importações de petróleo e garantir ocupação da capacidade ociosa das usinas (Vian, 2003).

Entre 1975 e 1979, o Proálcool enfatizou o aproveitamento da capacidade ociosa das destilarias anexas às usinas de açúcar pré-existentes para produção de álcool anidro. Entre 1980 e 1985, intensificou-se a utilização do álcool hidratado como combustível e, dessa forma, deu-se prioridade à implantação de destilarias autônomas (Alves, 2002). O Proálcool foi um estímulo ao surgimento de muitas das usinas que atualmente operam no mercado.

Durante a década de 80, o álcool passou a ser o produto dinâmico do complexo canavieiro, permitindo às empresas manter um crescimento da produção 
(Vian, 2003). Neste período houve incentivo à produção de veículos movidos a álcool tanto que, em 1985, chegaram a representar 95\% da produção total de carros no país.

A escassez de recursos governamentais marcou a década de 80 e conforme Moraes (2000, p.80), “o esgotamento das fontes oficiais de recursos evidenciou a dificuldade do governo continuar intervindo no setor, e os conflitos entre produtores e governo indicavam a necessidade de um novo modelo de intervenção governamental". Além disso, no final da década de 80, o Brasil presenciou duas graves crises de desabastecimento de álcool que gerou bastante desconfiança dos consumidores para com o setor, que perdurou por muitos anos e ainda se reflete nos dias atuais.

O principal desafio, segundo Vian (2003, p.95), enfrentado pelo setor ao final dos anos 80 "era o de superar o desgaste da imagem causado pelo desabastecimento de álcool em 1988/89, que teve como conseqüência a queda da procura e da produção dos carros a álcool nos anos 90”.

O impacto dos problemas do Proálcool foi distinto para as diferentes regiões: as regiões de fronteira, onde foram construídas a maioria das destilarias autônomas incentivadas pelo Programa, buscaram a diversificação, porém as cotas de produção tornaram-se obstáculos para muitas empresas que não possuíam recursos financeiros abundantes. Essa conjuntura impunha desafios de buscar produtos alternativos para viabilizar aumento da capacidade produtiva. A cogeração e o uso de subprodutos apareciam como alternativas, mas dependiam de investimentos em tecnologia e pesquisa. Os agentes acabaram tomando decisões individuais para superar a crise o que acabou acarretando em nova crise nos anos 90 .

Segundo Moraes (2000), o processo de liberalização econômica, iniciado no governo Collor, afetou o ambiente institucional e organizacional do setor sucroalcooleiro, seu sistema de fixação de preços, suas formas de comercialização, o controle da produção, as políticas de sustentação do álcool combustível e da cana-deaçúcar e o modo de atuação dos agentes envolvidos. 
A autora afirma ainda que em março de 1996, uma portaria do Ministério da Fazenda liberou os preços da cana, dos fretes, do açúcar cristal standard, dos álcoois carburantes e não carburantes de todos os tipos e do mel residual. Era previsto que esta portaria entrasse em vigor em janeiro do ano seguinte, porém ocorreram vários adiamentos que refletiram as dificuldades do processo e os conflitos de interesse. Por fim, a liberação do preço do álcool anidro ocorreu em maio de 1997 e a dos outros produtos somente em fevereiro de 1999.

Neste novo ambiente institucional, ocorreram várias alterações tanto no segmento público, quanto no privado. O IAA foi extinto em 1990 e surgiram agências, conselhos, associações e entidades de classe a fim de preencher as lacunas decorrentes do afastamento do Estado.

Vian (2003) analisa as implicações da falta de consenso entre os agentes no contexto de retirada progressiva do Estado das arenas de regulação nos anos 90 . O autor utiliza o conceito de Campos Organizacionais ${ }^{7}$ para mostrar que o complexo canavieiro estava fragmentado em pelo menos dois destes campos no que se refere à intervenção estatal e ao papel do IAA: um campo organizacional liderado pela Copersucar e outro pela Sopral que tinham opiniões opostas sobre estes assuntos.

Em 1998 foi instituído o Conselho de Produtores de Cana-de-açúcar, Açúcar e Álcool de São Paulo, o Consecana, mecanismo de auto-gestão para pagamento da matéria-prima aos fornecedores a fim de substituir a antiga tutela governamental. Este mecanismo passa a adotar a quantidade de açúcar total recuperável (ATR) para calcular o teor de sacarose da cana e a considerar que as oscilações de preço do álcool e do açúcar serão repassadas ao preço pago pela cana. Neste período houve ainda o enfraquecimento da mesa de comercialização do governo, dado que suas cotas não eram

\footnotetext{
7 Campo Organizacional é conceituado como uma arena institucional onde se pode visualizar a interdependência entre os agentes de uma cadeia produtiva. É um conceito mais amplo que a empresa vista individualmente e menos amplo que o complexo / setor como um todo. Há vários campos organizacionais dentro do complexo canavieiro, ou seja, conjuntos de empresas com interesses comuns inseridas num contexto onde outras empresas do mesmo ramo possuem interesses divergentes sobre o mesmo assunto. Porém todas as empresas do complexo possuem pelo menos um interesse em comum.
} 
suficientes para escoar toda a produção, fazendo com que a informalidade no mercado de álcool chegasse a representar 50\% deste mercado (Moraes, 2000).

Em 1999, ocorre uma crise em função da superprodução observada que desestabiliza o rendimento do setor e gera uma mobilização de todos os agentes envolvidos a fim de sensibilizar o governo e a sociedade sobre os problemas do setor, o que resultou no "Pacto pelo Emprego no Agronegócio Sucroalcooleiro".

Os anos 90 foram, portanto, marcados pelo afastamento do Estado e pela desregulamentação do setor. Estas mudanças nas instituições ligadas ao setor sucroalcooleiro durante a década de 90 influenciaram de maneira significativa a formulação das estratégias empresariais. O desmonte do aparato estatal que gerenciava as atividades do setor conduziu à necessidade de se realizar adequações para conviver com o livre mercado.

Como conseqüência dos interesses fragmentados dos usineiros e, por conseguinte, da existência de diversos Campos Organizacionais no complexo canavieiro, “as respostas aos problemas foram descoordenadas e contribuíram para seu agravamento. Mas o aprendizado foi grande e finalmente aconteceu a consolidação do complexo em torno de interesses comuns a todos, embora as empresas sejam concorrentes no âmbito comercial e pertençam a Campos Organizacionais distintos" (Vian, 2003, p.96).

A União da Agroindústria Açucareira de São Paulo (UNICA) surge neste contexto tratando profissionalmente de assuntos que importam para todas as empresas do complexo tais como tributação, comércio exterior, cogeração de energia, legislação ambiental e questões relativas ao álcool. Já as decisões comerciais e de investimento, específicas de cada agente individual, ficam a cargo das próprias empresas.

\footnotetext{
${ }^{8} \mathrm{O}$ pacto foi assinado pelos governos federal, estadual, diversos municipais, indústria automobilística, indústrias de açúcar e álcool, trabalhadores e distribuidoras de combustíveis. É válido até 2005, tem avaliações anuais e seu objetivo é conter o desemprego no setor, fortalecendo a atividade.
} 
As mudanças mais importantes no complexo vêm ocorrendo na forma de conduzir a produção e na comercialização dos produtos. Segundo Belik, Ramos \& Vian (1998), as usinas passaram a adotar diferentes tipos de estratégias para se adaptarem ao novo ambiente institucional, quais sejam: estratégias de diferenciação do produto, de diversificação produtiva e de aprofundamento e especialização na produção de açúcar e álcool.

Vian (2003) mostra que a desregulamentação gerou impactos regionais, com o Nordeste perdendo participação relativa para o Centro-Sul. Houve uma descentralização da produção de açúcar, pois muitas destilarias autônomas passaram a produzir açúcar e álcool e houve aumento da importância relativa de regiões pioneiras como Paraná, Minas Gerais e Goiás na produção de açúcar, observando-se uma migração dos investimentos de empresários nordestinos em direção ao Centro-Sul motivados pela existência de terras férteis, topografia adequada para mecanização da colheita, possibilidade de expansão da produção (principalmente em regiões de fronteira agrícola para cana como o oeste paulista, Mato Grosso, Goiás e Minas Gerais) e também pela competitividade da logística do Centro-Sul, muitas vezes com possibilidade de utilização de transporte ferroviário e até mesmo hidroviário.

Para enfrentar os impactos da desregulamentação surgiram novas estratégias competitivas e observou-se a fragmentação do complexo agroindustrial em Campos Organizacionais. No ambiente regulado, as usinas e destilarias possuíam estruturas produtivas, mix de produtos e formas de inserção no mercado bastante semelhantes. Com a desregulamentação, o setor foi obrigado a se adaptar e a estruturar uma nova dinâmica concorrencial. "A competição baseada no plantio nas melhores terras e na eficácia produtiva foi substituída por novas formas de concorrência. Todavia, algumas características permaneceram, como a integração vertical para trás” (Vian, 2003, p.133).

Qualidade, marca, embalagem, preços e prazos passaram a fazer parte do cotidiano de muitas indústrias de açúcar e álcool, caracterizando estratégias de diferenciação de produtos. Diferentes marcas, em diferentes tipos e tamanhos de 
embalagens, versões de açúcar light, com vitaminas, enfim, uma série de diferenciações buscando atender o consumidor final marcam a nova fase de reformulação da agroindústria canavieira.

Quanto à diversificação produtiva, ressaltam-se os exemplos das destilarias que fizeram as adaptações necessárias para a produção de açúcar, usinas que passaram a atuar no mercado pecuário, de cogeração e, eventualmente, até mesmo em outros mercados completamente distintos do açucareiro como o de sucos e chás. Belik, Ramos \& Vian (1998) afirmam que este tipo de estratégia permite que as empresas se beneficiem da experiência na produção agrícola integrada, das economias de escala e de escopo na produção industrial e agrícola, reduzam a sazonalidade do uso do parque industrial e das máquinas agrícolas e permite que se possa usufruir o uso comum de equipamentos, energia e dos subprodutos.

A estratégia de aprofundamento e especialização na produção envolve automação da produção, aumentos de produtividade, mecanização da colheita e também a otimização do sistema logístico. Belik, Ramos \& Vian (1998) afirmam que estas são estratégias elaboradas pelas usinas para reduzirem seus custos de transação e melhorarem a coordenação entre os elos da cadeia sucroalcooleira. A melhoria na logística dos produtos tanto no que se refere à movimentação física quanto no que tange ao gerenciamento e à estrutura de governança que rege a transação passa a ser objetivo das empresas.

Além destas estratégias, são importantes também os movimentos em relação à concentração e centralização de capitais que vêm ocorrendo através de fusões e aquisições, inclusive com relocalização de empresas. Já ocorreram muitas fusões e incorporações no Centro-Sul, com a presença de capital estrangeiro e migração de grupos nordestinos para esta região. Este processo tem permitido ganhos de escala, redução de despesas administrativas e de produção, uso racional de terras.

Vian (2003) afirma que as fusões e aquisições ocorreram por vários motivos. Observaram-se as fusões por sinergias e proximidade física entre as empresas (caso, por 
exemplo, da união entre Santa Elisa e São Geraldo, São Martinho e Iracema, e Santo Alexandre e Ipiranga); aquisições de empresas descapitalizadas (foram os casos, por exemplo, de venda das usinas Adelaide, Raffard, Amália, Diamante, Alcomira e Serrana); migração do capital nordestino para o Centro-Sul (casos do Grupo Petribu adquirindo a Destilaria Água Limpa, Grupo José Pessoa comprando a Benálcool, Grupo Carlos Lyra adquirindo a Usina Delta etc.); e, finalmente, algumas aquisições foram motivadas pela entrada do capital estrangeiro no setor (por exemplo, o Grupo Dreyfus adquiriu as usinas Cresciumal e Luciânia, a Glencore adquiriu a Portobello, a Guarani foi comprada pelo grupo EBS e a Univalem pelo grupo FBA).

A tendência de concentração persiste nos dias atuais. A primeira aquisição de 2005, por exemplo, ocorreu depois de meses de negociação: o grupo Franco Brasileiro de Açúcar e Álcool (FBA) comprou a Destilaria Vale do Tietê (Destivale), de Araçatuba (SP). Com esta aquisição, a FBA passa a controlar quatro usinas no Estado de São Paulo. A unidade recém-adquirida está localizada na mesma região que as usinas Univalem e Gasa, que também pertencem à FBA. O grupo também tem o controle da Ipaussu. A FBA, que foi criada em 2002, tem como acionistas os franceses Tereos e a brasileira Cosan com 47,5\% de participação cada um, e Sucden, também francesa, com 5\%. O novo negócio vai expandir os domínios dos grupos FBA e Cosan na região do noroeste do Estado, uma das poucas áreas em expansão de cana no Estado de São Paulo. Neste contexto, o grupo Cosan consolidou-se como o maior produtor de açúcar e álcool do mundo e conta com 13 usinas, além de estrutura portuária em Santos (Magalhães, 2005).

Segundo Vian (2003, p.188), “não há uma correlação direta entre escala produtiva, tipo de produto e localização com as estratégias adotadas pelas empresas". Ao contrário, unidades produtivas com a mesma escala de produção e tipo de inserção de mercado adotaram estratégias e obtiveram desempenhos distintos. $\mathrm{O}$ autor justifica esse fato, utilizando as idéias de Penrose, afirmando que isso ocorre porque as empresas são comandadas por pessoas com visões de mundo diferentes e com objetivos futuros específicos, trilhando, desta forma, caminhos próprios. O autor conclui que "não é 
possível traçar um padrão ou tendência estratégica para o setor como um todo, sendo necessária a análise dos diversos Campos Organizacionais em construção no momento" (p.194).

No complexo agroindustrial da cana ainda persistem questões regionais, conflitos entre usinas e fornecedores e heterogeneidade tecnológica. Alguns desafios tais como a baixa elasticidade-renda da demanda do açúcar, o consumo per capita brasileiro alto e estabilizado (em torno de $50 \mathrm{~kg} /$ habitante/ano), o baixo consumo mundial per capita (20 kg/ano), protecionismos e subsídios no mercado externo perduram e as estratégias desenvolvidas pelos produtores e traders devem tentar superá-los ou compensá-los (Vian, 2003).

Além dos aspectos históricos, importantes no entendimento tanto da configuração espacial atual das unidades produtoras de açúcar e álcool como das novas estratégias que vêm sendo utilizadas por estas usinas, é relevante destacar que o mercado sucroalcooleiro brasileiro tem características que o tornam peculiar em termos globais e bastante específico em termos logísticos. Fatores como a matéria-prima utilizada, sua produtividade, o volume produzido e o exportado, a sazonalidade, os subprodutos obtidos, dentre outros, têm implicações nas estratégias adotadas, inclusive na localização das unidades produtoras e nas estratégias logísticas por elas adotadas. Estes fatores serão detalhados a seguir.

\subsubsection{A cultura da cana-de-açúcar no Brasil}

O Brasil possui duas macro-regiões produtoras de açúcar e álcool: o CentroSul e o Norte-Nordeste ${ }^{9}$, cujos níveis de produtividade, vocação e sazonalidades são distintos. A safra do Centro-Sul estende-se basicamente de maio a novembro e a do

\footnotetext{
${ }^{9}$ A região denominada de Centro-Sul é composta pelos seguintes estados: São Paulo, Paraná, Minas Gerais, Mato Grosso, Mato Grosso do Sul, Goiás, Rio de Janeiro, Espírito Santo, Rio Grande do Sul e Santa Catarina. Os seguintes estados compõem a região Norte-Nordeste: Alagoas, Bahia, Ceará, Maranhão, Pará, Paraíba, Pernambuco, Piauí, Rio Grande do Norte, Sergipe e Tocantins.
} 
Norte-Nordeste, de setembro a fevereiro, facilitando o abastecimento interno e externo e implicando sazonalidade do transporte e necessidade de armazenamento.

Conforme ressalta Moraes (2004), uma característica importante que sempre deve ser lembrada é que a cadeia produtiva sucroalcooleira tem como principal insumo um produto agrícola e, portanto, está sujeita a intempéries climáticas, fitossanitárias e à sazonalidade da produção. Isto se torna ainda mais importante quando se observa a importância da produção da cana-de-açúcar brasileira no mundo.

O Brasil é o maior produtor de cana-de-açúcar do mundo produzindo, na safra 2003/2004, 359 milhões de toneladas do produto. A Figura 1 mostra a tendência crescente da produção de cana no Brasil durante o período que se estende da safra 1990/1991 à safra 2003/2004. Cabe ressaltar que a quebra ocorrida na safra 2000/2001 foi fruto do desencontro das medidas tomadas pelos usineiros para enfrentar a crise advinda da perspectiva de liberação dos preços e da existência de elevados estoques de açúcar e álcool da safra 1998/1999 que implicou em queda de preços dos produtos. Devido à crise, as usinas paulistas anteciparam o fim da safra 1998/1999 e reduziram o plantio para safra seguinte. A cana "bisada" (cana que fica no campo para safra seguinte), os baixos investimentos em renovação de canaviais e em tratos culturais foram fatores que refletiram no baixo desempenho da safra 1999/2000.

Embora os preços pagos pela tonelada de cana tenham aumentado na safra 1999/2000 devido à escassez de produto, os volumes de entrega às usinas foram menores, comprometendo a garantia de renda ao produtor nos níveis necessários ao investimento na lavoura. Uma produção sem investimentos, aliada às condições climáticas desfavoráveis (estiagem e baixas temperaturas), implicaram na quebra da safra 2000/2001. 


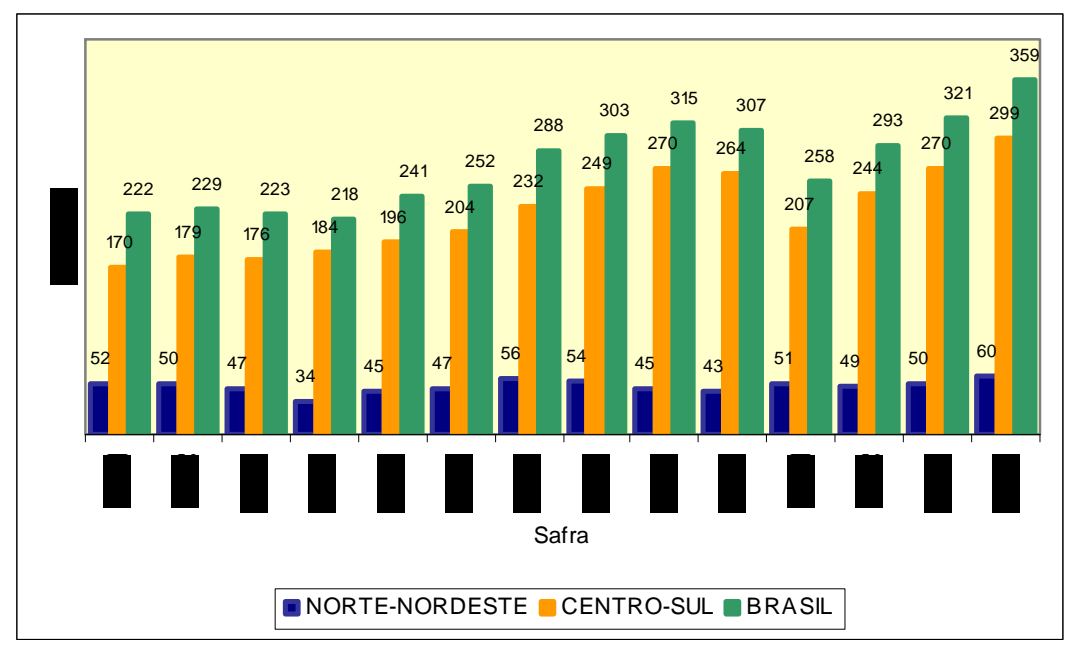

Figura 1 - Produção de cana-de-açúcar no Brasil

Fonte: elaborado a partir de UNICA (2005)

A região Centro-Sul contribuiu com aproximadamente $88 \%$ do volume de cana produzido na safra 2003/2004, enquanto a Norte-Nordeste produziu $12 \%$ do total brasileiro. O estado de São Paulo destaca-se como o mais importante pólo sucroalcooleiro do mundo, conforme ilustrado na Figura 2 que mostra a participação dos estados na produção de cana-de-açúcar no Brasil.

As usinas do Centro-Sul são privilegiadas pelo clima favorável, terras férteis, topografia adequada e alto nível tecnológico, o que as tornam bastante eficientes, produtivas e detentoras do menor custo de produção do mundo. Vian (2003) cita que o rendimento médio da lavoura canavieira no Brasil na safra 1999/2000 foi de 69,25 t/ha, sendo que a média do Centro-Sul foi de 74,20 t/ha. São Paulo se destaca neste ambiente moendo cerca de $60 \%$ da cana-de-açúcar nacional e $70 \%$ da região Centro-Sul, com rendimento de 78,85 t/ha que permite produzir $62 \%$ do álcool e $65 \%$ do açúcar brasileiro.

A região Norte-Nordeste, onde se encontram cerca de $26 \%$ das unidades produtoras de açúcar e álcool do país, é seca, de relevo acidentado (o que dificulta a 
mecanização) e as usinas aí instaladas são menos produtivas que as do Centro-Sul: cada hectare produziu na safra 1999/2000, em média, 50,47 toneladas de cana. Destacam-se como maiores produtores nesta região os estados de Alagoas e Pernambuco. As usinas aí localizadas respondem por $16 \%$ da exportação nacional de açúcar e detém a totalidade das cotas de exportação para os EUA. As usinas desta região contaram com subsídio do governo federal (Programa de Equalização, suspenso há 3 anos) a fim de compensar a diferença de custos de produção com relação ao Centro-Sul.

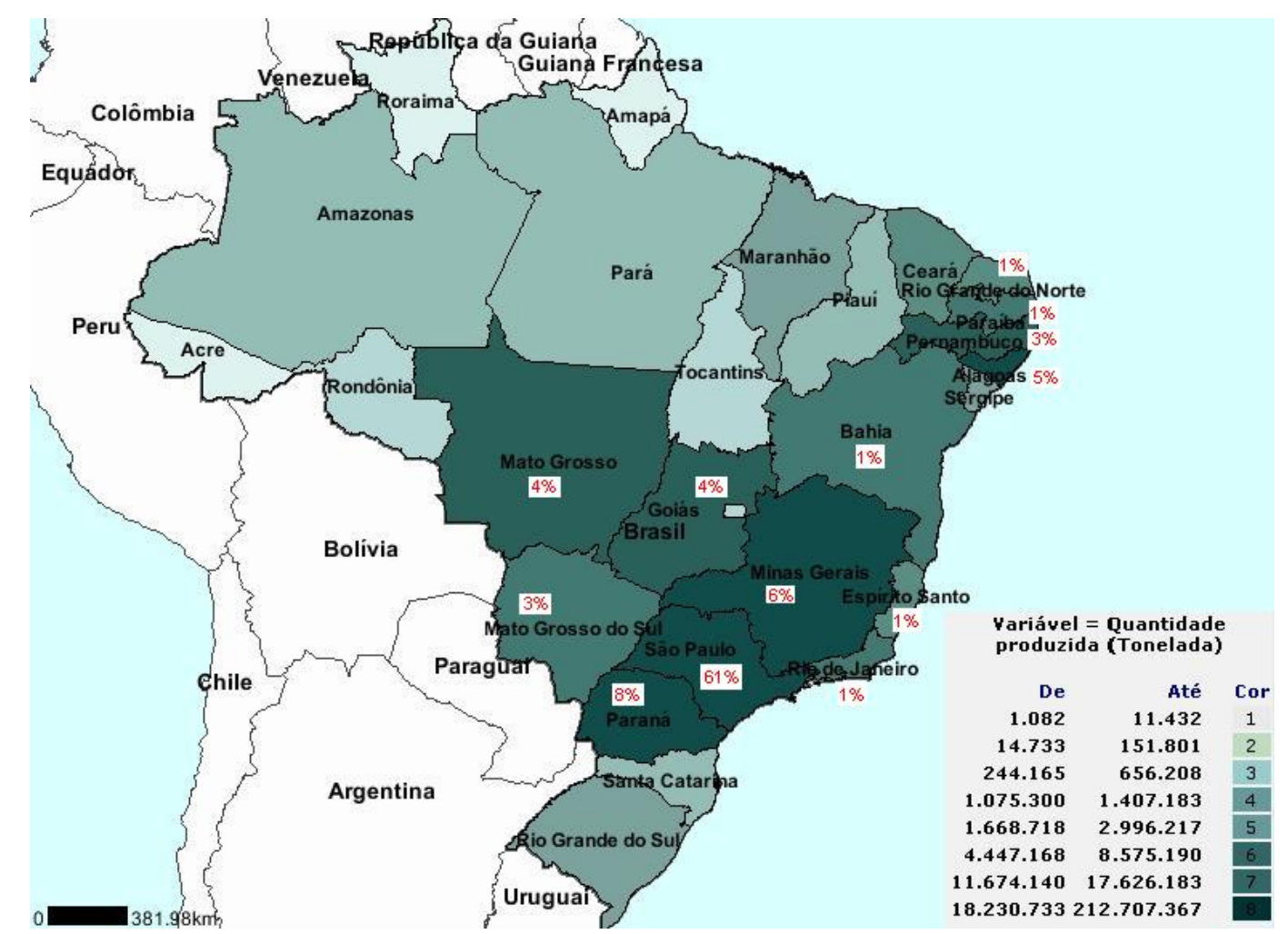

Figura 2 - Participação dos estados brasileiros na produção de cana-de-açúcar, safra $2003 / 2004$

Fonte: adaptado a partir de UNICA (2004) e IBGE (2004) 
Segundo dados do IBGE (2004), discriminados na Tabela 2, em 2002, a cana-de-açúcar ocupou uma área plantada de 5,2 milhões de hectares, ou seja, área inferior à ocupada pela soja (16,4 milhões) e pelo milho (12,3 milhões). No entanto, a produção de cana soma 364 milhões de toneladas, o que é superior à produção de todos os principais grãos somados (soja, milho, arroz, feijão, sorgo, centeio, cevada, trigo) que chega a cerca de 96 milhões de toneladas. Deve-se isso ao elevado rendimento da cana, cerca de 70 toneladas por hectare, volume bastante superior aos grãos que ficam entre 2 e 3 toneladas por hectare.

Tabela 2. Quantidade produzida, área plantada e produtividade média, 2002

\begin{tabular}{lccc}
\hline \multicolumn{1}{c}{ Produto } & $\begin{array}{c}\text { Quantidade } \\
\text { produzida (mil t) }\end{array}$ & $\begin{array}{c}\text { Área plantada } \\
(\mathrm{mil} \mathrm{ha})\end{array}$ & $\begin{array}{c}\text { Produtividade } \\
(\mathrm{t} / \mathrm{ha})\end{array}$ \\
\hline Cana-de-açúcar & 364.391 & 5.207 & 70,0 \\
Soja & 42.125 & 16.382 & 2,6 \\
Milho & 35.933 & 12.295 & 2,9 \\
Arroz & 10.457 & 3.176 & 3,3 \\
Trigo & 3.106 & 2.152 & 1,4 \\
Feijão & 3.064 & 4.322 & 0,7 \\
Sorgo & 787 & 516 & 1,5 \\
Cevada & 245 & 156 & 1,6 \\
Centeio & 5 & 5 & 1,0 \\
Sub-total* & 95.721 & 39.003 & 2,5 \\
Total & 460.112 & 44.210 & 10,4 \\
\hline
\end{tabular}

Fonte: elaborado a partir de IBGE (2004)

* Não inclui a cana-de-açúcar

A cana-de-açúcar é uma cultura de clima tropical que se adaptou muito bem às condições edafoclimáticas brasileiras. É bastante resistente a variações climáticas e 
pragas e, além disso, há no país uma tradição de pesquisa no setor que levou para o mercado espécies com tipos genéticos que as tornam ainda mais resistentes e adaptadas. Estas pesquisas são desenvolvidas por instituições como o Centro de Tecnologia Canavieira (CTC), Embrapa, Instituto Agronômico (IAC) e outras como a divisão de capital de risco do grupo Votorantim.

A cultura da cana-de-açúcar é perene: a cana da mesma planta pode ser colhida até cinco vezes e seu ciclo produtivo é longo, com um período entre plantio e última colheita podendo durar entre 5 e 7 anos. Do plantio até a primeira colheita decorrem cerca de 18 meses. Geralmente, as usinas renovam cerca de $20 \%$ do seu canavial por ano. A cana de um ano, chamada de primeiro corte é, geralmente, a mais produtiva, a cana do segundo corte denomina-se cana-soca e a do terceiro em diante, cana-ressoca.

Os principais produtos obtidos através do processamento da cana-de-açúcar são: açúcar, álcool, bagaço, xaropes, torta de filtro, vinhaça concentrada e melaço. Os principais tipos de açúcares exportados são demerara ${ }^{10}$ (obtido por clarificação controlada, apresenta cristais regulares), VHP (Very High Polarizated, açúcar cristal com grau de polarização máximo igual a 99,5 Z) e refinado granulado (elevada pureza, obtido por dissolução, purificação e recristalização de açúcar cristal, apresenta cristais bem definidos e granulometria uniforme). $\mathrm{O}$ açúcar cristal (obtido por fabricação direta nas usinas, sofre o efeito de clarificação por tratamentos físico-químicos) tem como principal destino a indústria e o consumo direto, principalmente na região NorteNordeste. O açúcar refinado amorfo (obtido por dissolução e purificação do açúcar cristal, com granulometria fina e alta capacidade de dissolução) é o açúcar branco consumido principalmente na região Centro Sul do país.

O álcool pode ser classificado em 3 categorias. O álcool anidro carburante é composto por um teor alcoólico mínimo de 99,3 INPM e é utilizado como aditivo aos combustíveis, enquanto que o hidratado (teor alcoólico mínimo de 92,6 $6^{\circ}$ INPM) é

\footnotetext{
${ }^{10}$ As definições dos tipos de açúcares encontram-se em Cosan (2004) e Copersucar (2004)
} 
utilizado diretamente nos carros movidos a álcool ou flex fuel. O álcool neutro é utilizado na fabricação de bebidas, cosméticos, produtos químicos e farmacêuticos. $\mathrm{O}$ bagaço de cana é utilizado como combustível nas caldeiras das usinas para geração de calor e para co-geração de energia ${ }^{11}$ ou são vendidos para outras indústrias para este mesmo fim. Os xaropes são utilizados na indústria de refrigerantes e farmacêutica; a torta de filtro e a vinhaça são utilizadas como fertilizantes. O melaço é usado na fabricação de cachaça, rum, levedura e ração. São muitas as utilizações dos subprodutos da produção de açúcar e álcool, porém a viabilidade econômica de alguns ainda é questionada.

A possibilidade de produzir tanto açúcar como álcool proporciona às usinas uma capacidade de arbitragem bastante importante, que se baseia nos preços de mercado dos dois produtos e depende do nível de comprometimento de venda prévio realizado pela unidade produtora. Em alguns períodos, a produção de açúcar vai estar relativamente mais rentável que a do álcool e a usina vai destinar sua matéria-prima para produção de açúcar ou vice-versa. Neste contexto, evidencia-se a importante função da armazenagem de produtos tanto para minimizar a necessidade de venda imediata do produto quanto para evitar, por exemplo, problemas com desabastecimento.

A cana é transportada do campo para a indústria geralmente em treminhões e descarregada diretamente nas esteiras que alimentam as moendas, pois a cana é perecível e deve ser consumida no processo produtivo em, no máximo, 48 horas e, por isso, as usinas trabalham 24 horas por dia, 7 dias por semana no período de safra com intuito de obter os melhores índices de açúcar recuperável da cana. Nos demais meses a linha de produção é desmontada e faz-se manutenção dos equipamentos. Esta sazonalidade traz características especiais para o transporte e para a armazenagem dos produtos derivados da cana, que serão discutidas no item 2.2.4.

\footnotetext{
${ }^{11}$ A maioria das usinas é auto-suficiente na geração de energia elétrica através da queima do bagaço, permitindo uma redução dos custos de produção. Algumas usinas conseguem gerar excedentes e vendê-los às companhias distribuidoras de energia elétrica.
} 
O próximo tópico diz respeito ao mercado de açúcar, foco deste trabalho, porém antes disso cabem algumas observações atuais relevantes sobre o mercado de álcool no país que, com certeza, afetam diretamente o mercado de açúcar.

Recentemente, dois fatos fizeram surgir um mercado potencial para o álcool do país bastante importante. No início de 2003, as montadoras anunciaram, no Brasil, a comercialização dos automóveis bi-combustível (também conhecidos com flex fuel), que podem ser movidos com qualquer proporção de álcool ou gasolina. Foi uma iniciativa de bastante sucesso que pode ser visto com o aumento vertiginoso das vendas deste tipo de automóvel: em 2004 foram vendidos quase 380 mil veículos flex fuel no país, crescimento de $348 \%$ em relação a 2003 (UNICA, 2005).

Outro fato relevante foi a implantação do Protocolo de Kyoto que passou a ser legalmente compulsório para seus participantes a partir de 16 de fevereiro de 2005, depois de ter cumprido duas condições: ratificação por ao menos 55 países e apoio de países desenvolvidos responsáveis por ao menos 55 por cento das emissões de gases do efeito estufa. O objetivo do acordo é reduzir a emissão de gases que causam o efeito estufa em 5,2 por cento dos níveis de 1990, o que deve acontecer entre 2008 e 2012. Isso gerou uma expectativa de crescimento da exportação de álcool que já está sendo observada. As exportações de álcool de 2004, segundo a UNICA (2005), chegaram a 2,26 milhões de metros cúbicos contra 762 milhões no ano anterior.

\subsubsection{O mercado açucareiro brasileiro}

Segundo o USDA (2004), a produção mundial de açúcar cresceu aproximadamente $25 \%$ na última década e atualmente é da ordem de 142 milhões de toneladas, conforme se pode observar na Figura 3. A produção da safra atual foi menor que a anterior devido à quebra de safra da Índia, da União Européia e da China devido à estiagem. Observa-se que o açúcar de cana é mais representativo em termos mundiais e tem menor custo de produção que os obtidos de outras fontes de matéria-prima. 


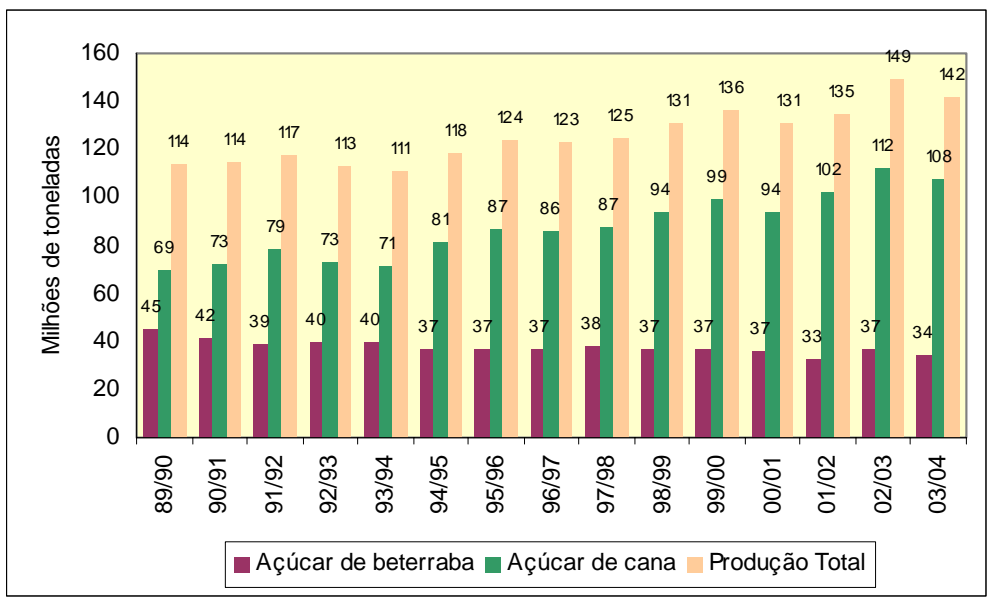

Figura 3 - Produção mundial de açúcar, 1989/1990 a 2003/2004

Fonte: elaborado a partir de USDA (2004)

O Brasil passou de uma produção da ordem de 8 milhões de toneladas de açúcar no início da década de 90 para liderar o ranking de produtores na década seguinte com cerca de 27 milhões de toneladas, ultrapassando o volume produzido pela Índia e União Européia. A Figura 4 ilustra o extraordinário crescimento da produção brasileira comparada com a de outros países que se destacam na produção global de açúcar. 


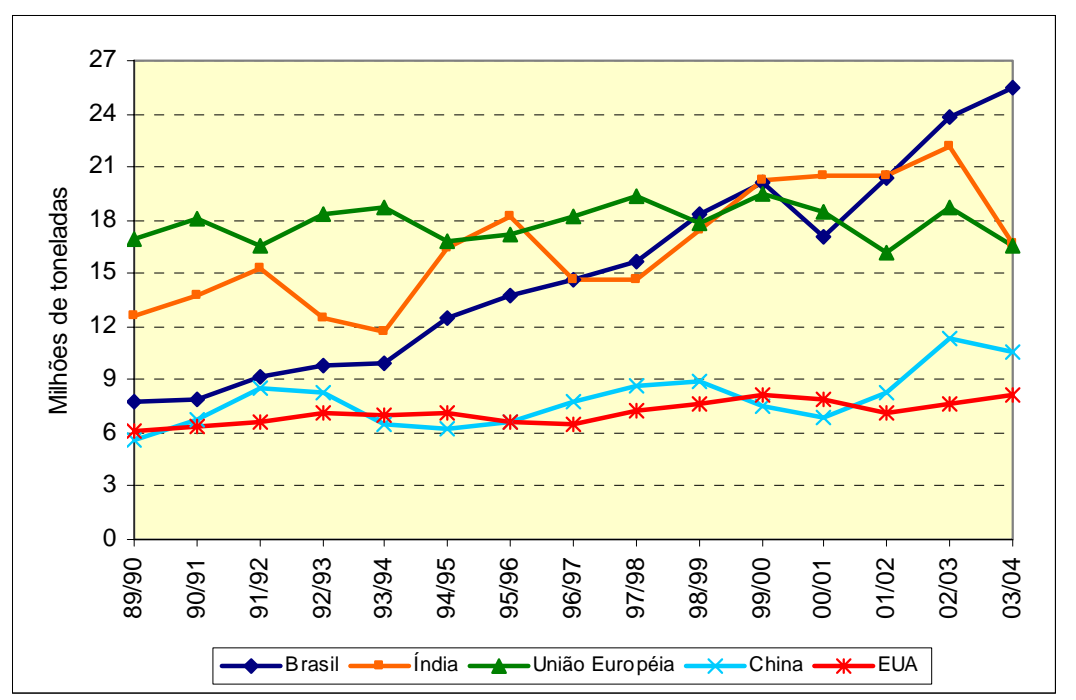

Figura 4 - Produção mundial de açúcar, 1989/1990 a 2003/2004

Fonte: elaborado a partir de USDA (2004)

A Figura 5 ilustra a evolução da produção de açúcar nas últimas 14 safras e mostra a importância relativa do Centro-Sul e do Norte-Nordeste. Cabe observar que houve quebra de safra em 2000/2001 no Centro-Sul devido a condições climáticas desfavoráveis e falta de investimento em tratos culturais devido à crise de 1999.

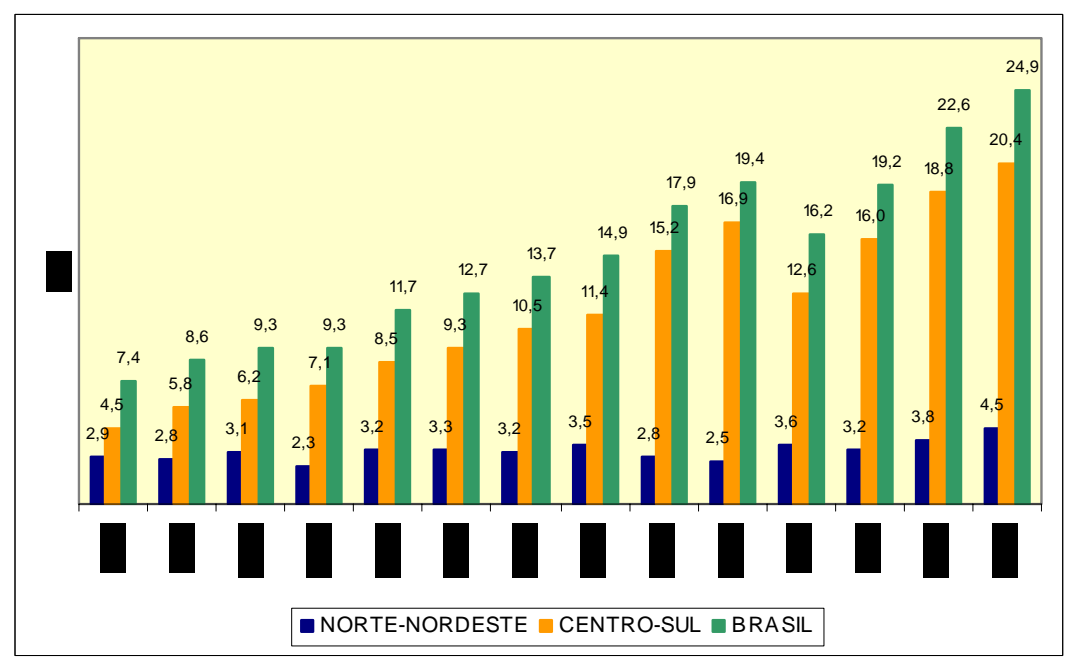

Figura 5 - Evolução da produção de açúcar no Brasil

Fonte: elaborado a partir de UNICA (2005) 
A produção brasileira de açúcar está concentrada na região Centro-Sul do país, especialmente no estado de São Paulo que concentra mais de $60 \%$ da produção nacional, conforme ilustrado pela Figura 6. Os estados da região Norte-Nordeste vêm perdendo participação na produção nacional devido às condições menos favoráveis da região (vide Figura 7).

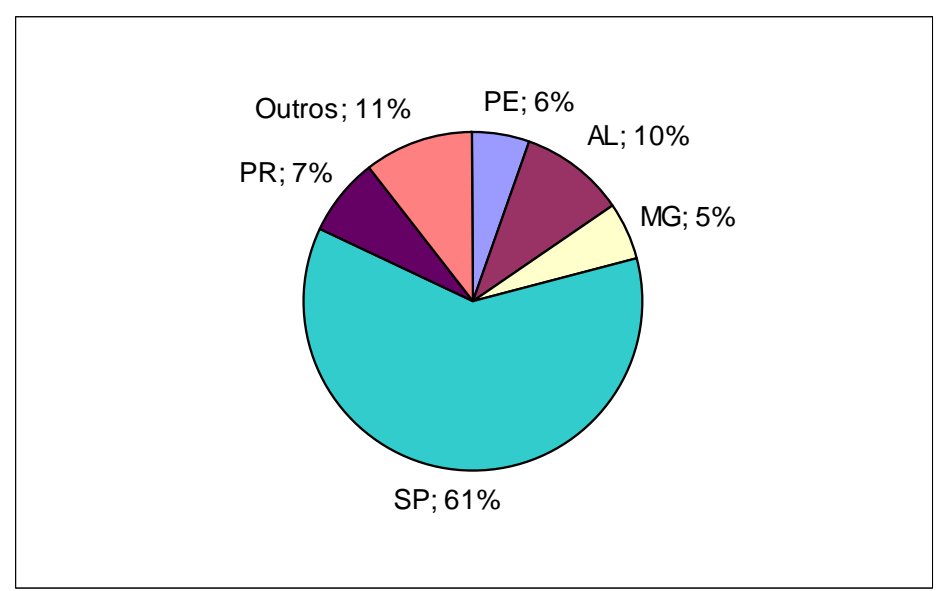

Figura 6 - Participação dos estados na produção nacional de açúcar, safra 2003/2004 Fonte: elaborado a partir de UNICA (2005)

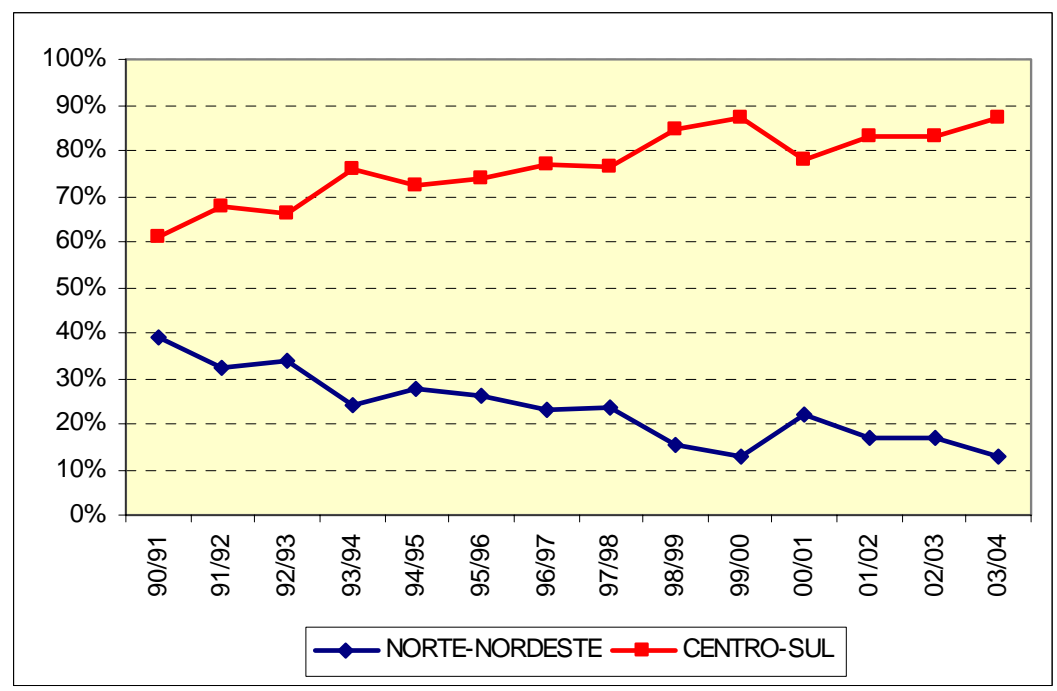

Figura 7 - Participação das regiões Norte-Nordeste e Centro-Sul na produção de açúcar do Brasil, 1990/1991 a 2003/2004

Fonte: elaborado a partir de UNICA (2004) 
A Figura 8 mostra que o desempenho da produção brasileira é altamente correlacionado com a produção paulista, porém a defasagem entre elas vem aumentando, mostrando que outras regiões estão aumentando seus volumes em proporções maiores que o estado de São Paulo. A Tabela 3 relata que outros estados menos tradicionais no setor vêm apresentando produções com taxas geométricas de crescimento mais altas que a de São Paulo, como são os casos de Minas Gerais, Mato Grosso do Sul, Paraná e Goiás quando se considera as últimas 8 safras. Estados como Rio de Janeiro e Pernambuco apresentam queda de produção, pois são áreas com problemas topográficos que dificultam o cultivo e mecanização da colheita da cana.

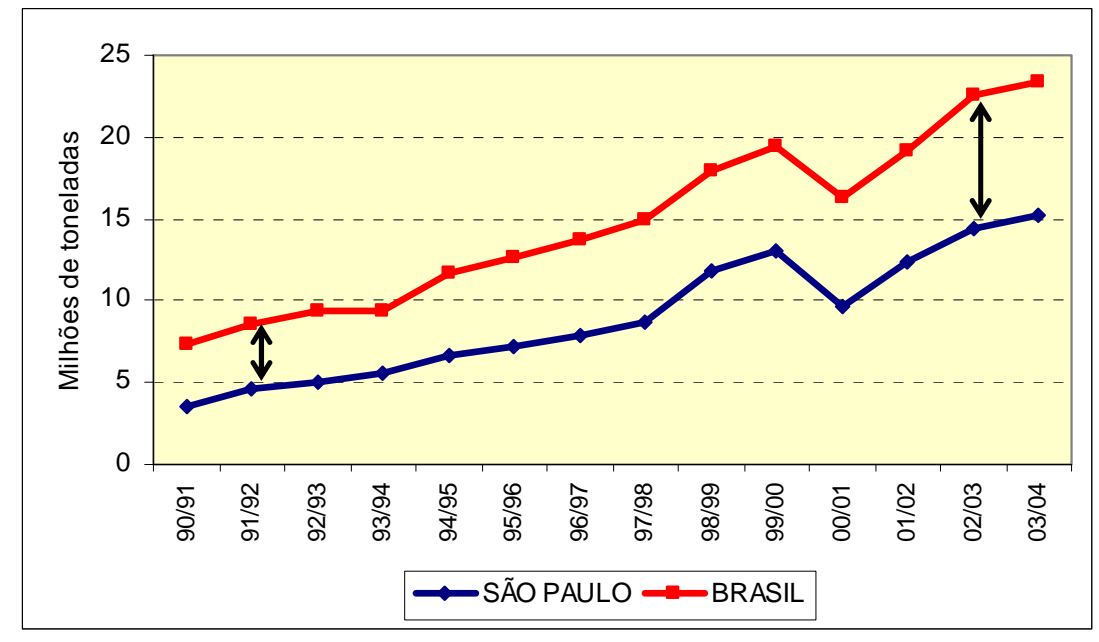

Figura 8 - Produção de açúcar no Brasil, 1990/1991 a 2003/2004

Fonte: elaborado a partir de UNICA (2004) 
Tabela 3. Produção de açúcar pelos estados brasileiros, 1996/1997 a 2003/2004, em mil de toneladas

\begin{tabular}{|c|c|c|c|c|c|c|c|c|c|}
\hline ESTADOS/SAFRA & $96 / 97$ & $97 / 98$ & 98/99 & $99 / 00$ & $00 / 01$ & $01 / 02$ & $02 / 03$ & $03 / 04$ & $\begin{array}{c}\text { Taxa } \\
\text { Geométrica } \\
\text { de } \\
\text { Crescimento } \\
\end{array}$ \\
\hline ALAGOAS & 1.509 & 1.774 & 1.312 & 1.215 & 2.059 & 1.678 & 1.994 & 1.525 & $2 \%$ \\
\hline PERNAMBUCO & 1.217 & 1.232 & 1.050 & 856 & 1.099 & 1.104 & 1.231 & 981 & $-1 \%$ \\
\hline BAHIA & 138 & 151 & 145 & 145 & 146 & 143 & 161 & 161 & $2 \%$ \\
\hline R. G. NORTE & 128 & 155 & 128 & 97 & 135 & 117 & 166 & 148 & $2 \%$ \\
\hline PARAÍBA & 79 & 105 & 66 & 78 & 74 & 115 & 143 & 99 & $6 \%$ \\
\hline SERGIPE & 60 & 73 & 46 & 49 & 72 & 56 & 69 & 36 & $-3 \%$ \\
\hline MARANHÃO & 25 & 9 & 14 & 23 & 10 & 12 & 3 & 11 & $-13 \%$ \\
\hline OUTROS & 27 & 27 & 21 & 24 & 17 & 20 & 22 & 23 & \\
\hline $\begin{array}{l}\text { NORTE- } \\
\text { NORDESTE }\left(^{*}\right)\end{array}$ & 3.185 & 3.526 & 2.782 & 2.487 & 3.613 & 3.246 & 3.789 & 2.984 & \\
\hline SÃO PAULO & 7.926 & 8.705 & 11.788 & 13.091 & 9.675 & 12.350 & 14.348 & 15.172 & $9 \%$ \\
\hline PARANÁ & 784 & 937 & 1.245 & 1.430 & 989 & 1.351 & 1.469 & 1.865 & $10 \%$ \\
\hline MINAS GERAIS & 489 & 494 & 625 & 802 & 620 & 747 & 1.093 & 1.347 & $14 \%$ \\
\hline RIO DE JANEIRO & 421 & 351 & 374 & 357 & 308 & 219 & 312 & 332 & $-5 \%$ \\
\hline GOIÁS & 309 & 285 & 341 & 369 & 397 & 506 & 577 & 668 & $13 \%$ \\
\hline $\begin{array}{l}\text { MATO GROSSO } \\
\text { MATO GROSSO }\end{array}$ & 301 & 367 & 483 & 485 & 370 & 448 & 546 & 579 & $8 \%$ \\
\hline DO SUL & 192 & 166 & 251 & 320 & 232 & 328 & 374 & 403 & $12 \%$ \\
\hline OUTROS & 53 & 50 & 54 & 45 & 45 & 23 & 59 & 54 & \\
\hline CENTRO-SUL & 10.475 & 11.354 & 15.160 & 16.900 & 12.636 & 15.972 & 18.778 & 20.420 & \\
\hline BRASIL & 13.659 & 14.881 & 17.942 & 19.388 & 16.249 & 19.218 & 22.567 & 23.405 & \\
\hline
\end{tabular}

Fonte: elaborado a partir de UNICA (2004)

*Nota: os dados da região N-NE na safra 03/04 referem-se à posição de 01/01/04

Desde meados dos anos 90, o Brasil é também o maior exportador de açúcar do mundo (vide Figura 9), participando com aproximadamente 30\% do comércio mundial. As exportações brasileiras destinam-se principalmente aos mercados da Rússia, Emirados Árabes, Nigéria e Canadá, dentre vários outros países (UNICA, 2004). É 
importante notar o aumento da participação do Brasil no comércio internacional de açúcar nos últimos anos, conforme ilustrado na Figura 10.

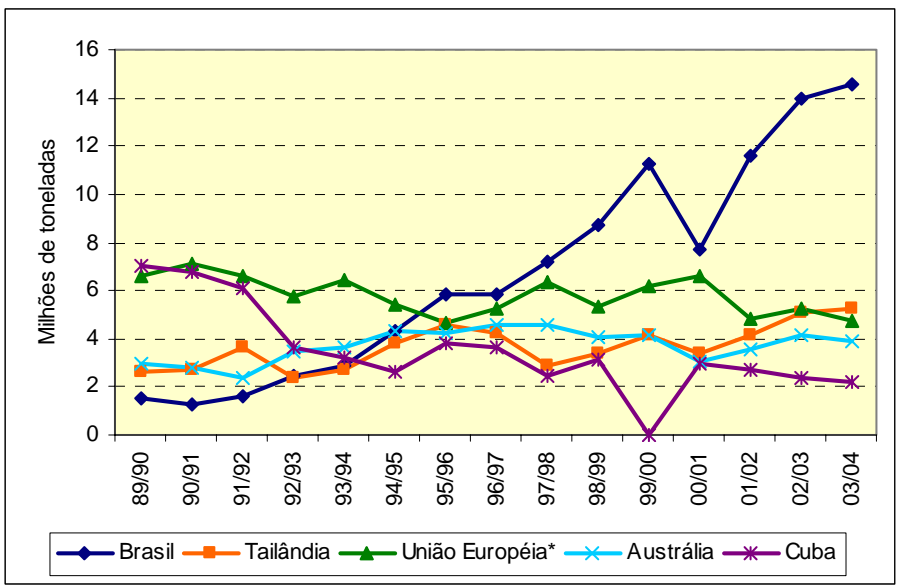

Figura 9 - Exportação mundial de açúcar, 1990 a 2004

Fonte: elaborado a partir de USDA (2004)

*Nota: inclui os 15 países que formavam a União Européia até abril de 2004

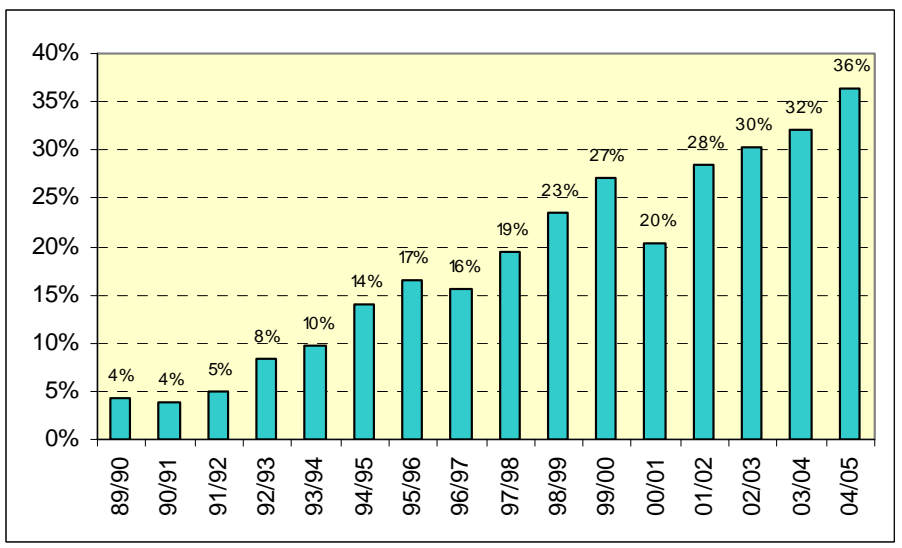

Figura 10 - Participação do açúcar brasileiro nas exportações mundiais, 1989/1990 a 2004/2005

Fonte: elaborado a partir de USDA (2004) 
As exportações brasileiras seguem uma sazonalidade que pode ser observada na Figura 11 e tem seu pico entre setembro e outubro. Este gráfico mostra também uma tendência de queda nos preços FOB, típico comportamento de commodities. Isto indica que cada vez mais os traders devem tentar diminuir os custos internos para manterem suas margens na comercialização internacional do açúcar e, neste contexto, entra a busca pela minimização dos custos logísticos.

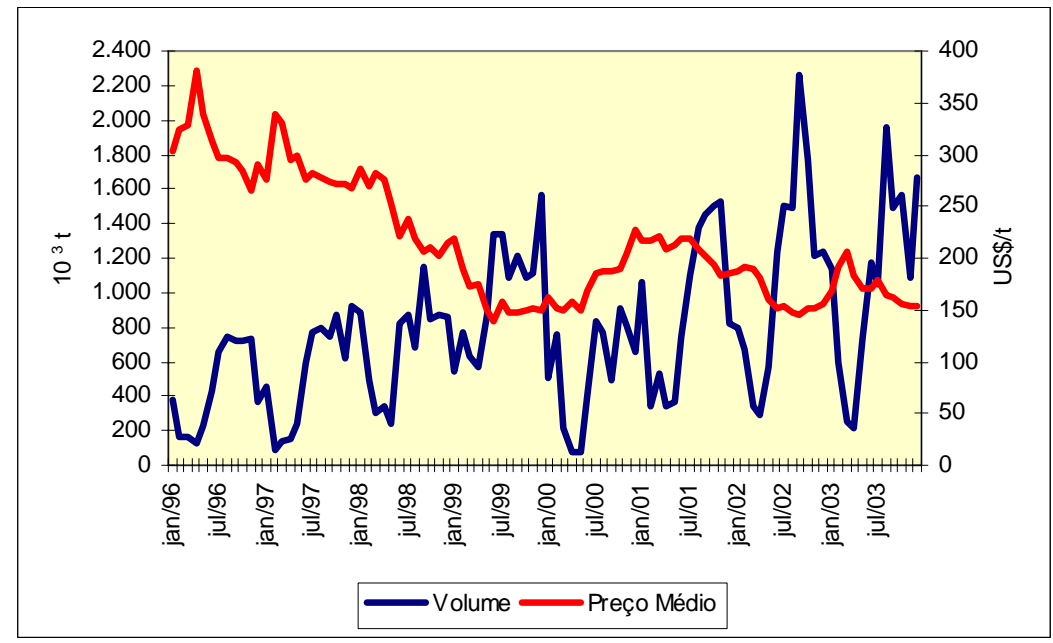

Figura 11 - Exportações brasileiras de açúcar, 1996 a 2003

Fonte: elaborado a partir de UNICA (2004)

O custo de produção do açúcar brasileiro é o menor do mundo, graças ao clima adequado e à fertilidade da terra aliados às melhorias genéticas que permitem a obtenção de um alto teor de sacarose na planta, e também ao baixo custo relativo de mão-de-obra e terra. 
Em muitos países ricos, o açúcar é um dos produtos agrícolas mais subsidiados. A União Européia ${ }^{12}$, os Estados Unidos e o Japão mantêm elevados preços mínimos através de subsídios à produção doméstica e de imposições de altas tarifas de importação. Atualmente, os preços do açúcar nestes países estão em níveis três vezes maiores que o preço do produto no mercado internacional.

As usinas da região Centro-Sul conseguem produzir açúcar a US\$ 180 por tonelada (em São Paulo o custo cai para US\$ 165 / t). Na Austrália e Tailândia, outros grandes produtores mundiais, as despesas atingem US\$ $335 / \mathrm{t}$, com matéria-prima de cana-de-açúcar. Na UE, o custo de produção bate US\$ 710 / t, com a beterraba como matéria-prima (Pinazza \& Alimandro, 2003). O comércio mundial dos produtos destes países somente é possível devido aos altos níveis de subsídios.

O percentual da produção brasileira que se destina ao mercado externo passou de um patamar de $40 \%$ em meados da década de 90 para um de $60 \%$ nas últimas safras (vide Figura 12). Pode-se dizer que grande parte do volume adicional produzido neste período foi exportada. Isso ocorre porque o consumo interno brasileiro está relativamente estabilizado e porque o açúcar é um produto indiferenciado que possui demanda inelástica. Hoffman ${ }^{13}$ (2000) citado por Vian (2003) mostra que a elasticidade renda da demanda por açúcar é de 0,3 .

\footnotetext{
12 “Ao incentivar o excedente de produção de beterraba entre seus produtores, a União Européia distorce o mercado internacional do açúcar, à medida que subsidia suas exportações acima dos limites estabelecidos por acordos internacionais de comércio. Essa prática levou o Ministério das Relações Exteriores a comunicar à Organização Mundial do Comércio (OMC) que o Brasil entraria com pedido de abertura de 'panel' (comitê de arbitragem), junto ao Órgão de Solução de Controvérsias da entidade, contra os subsídios que ferem o Acordo sobre Agricultura firmado na Rodada Uruguai do Gatt (Acordo Geral de Tarifas e Comércio). O pedido de 'panel' foi oficializado em 21 de julho, foi barrado, como é de praxe, e reapresentado em 29 de agosto, data de sua instauração.[...] A União Européia estabelece tarifa de importação de 339 euros por tonelada de açúcar bruto para refino e de 419 euros para os demais tipos" (http://www.portalunica.com.br/acao/mercado.jsp).

${ }^{13}$ HOFFMAN, R. Elasticidades-renda das despesas com alimentos em regiões metropolitanas do Brasil em 1995-96. Informações Econômicas, v.30, n.2, p.17-24, fev. 2000.
} 


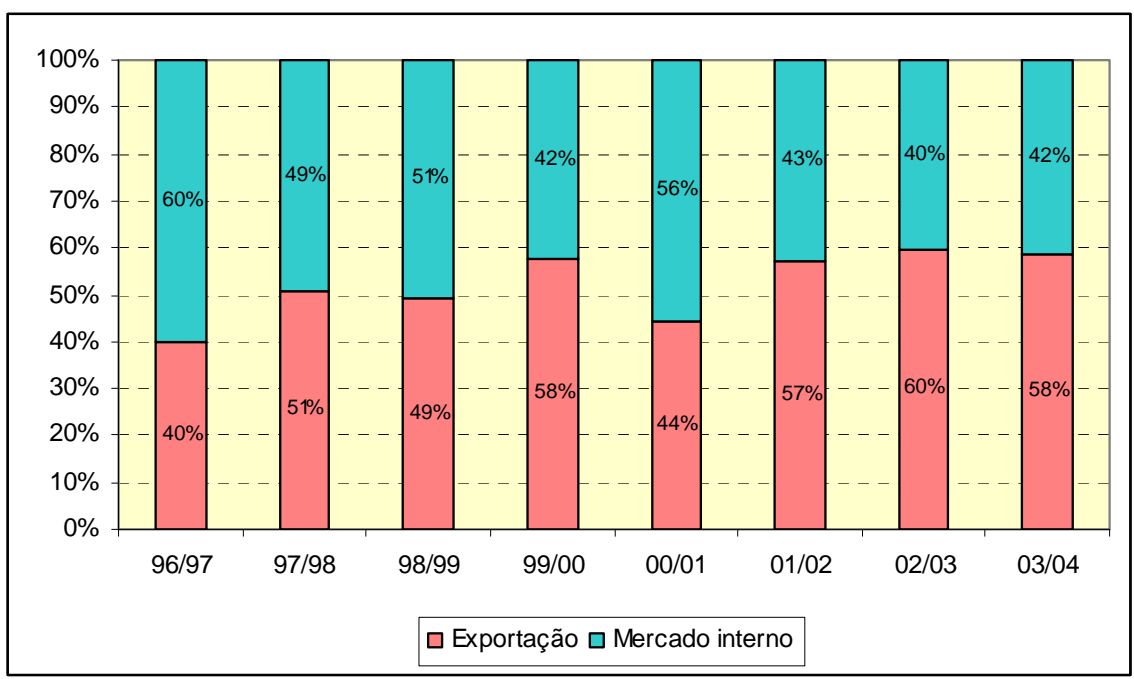

Figura 12 -Percentual da produção de açúcar brasileiro destinado ao mercado interno e à exportação, 1996/1997 a 2003/2004

Fonte: elaborado a partir de UNICA (2004)

A Tabela 4 mostra a importância relativa dos Portos de Santos e de Paranaguá, por onde passaram 67\% e 13\%, respectivamente, das exportações brasileiras de açúcar em 2003. Percebe-se o aumento da participação do Porto de Santos que passou de 50\% em 1996 para 67\% em 2003. Na região Norte-Nordeste, os principais portos exportadores de açúcar são os de Maceió e Recife. 
Tabela 4. Exportação de açúcar por porto, em mil toneladas

\begin{tabular}{lccccccccccccccccc}
\hline \multirow{2}{*}{ PORTOS } & \multicolumn{2}{c}{1996} & \multicolumn{1}{c}{1997} & \multicolumn{2}{c}{1998} & \multicolumn{2}{c}{1999} & \multicolumn{2}{c}{2000} & \multicolumn{2}{c}{2001} & \multicolumn{2}{c}{2002} & \multicolumn{2}{c}{2003} \\
& Volume & $\%$ & Volume & $\%$ & Volume & $\%$ & Volume & $\%$ & Volume & $\%$ & Volume & $\%$ & Volume & $\%$ & Volume & $\%$ \\
\hline Santos & 2721 & $50 \%$ & 2338 & $37 \%$ & 3745 & $45 \%$ & 7075 & $59 \%$ & 3787 & $59 \%$ & 6717 & $60 \%$ & 8243 & $65 \%$ & 8704 & $67 \%$ \\
Paranguá & 955 & $18 \%$ & 1500 & $24 \%$ & 2199 & $26 \%$ & 2397 & $20 \%$ & 1236 & $19 \%$ & 2089 & $19 \%$ & 2005 & $16 \%$ & 1721 & $13 \%$ \\
Maceió & 693 & $13 \%$ & 908 & $14 \%$ & 868 & $10 \%$ & 937 & $8 \%$ & 785 & $12 \%$ & 1343 & $12 \%$ & 1360 & $11 \%$ & 1583 & $12 \%$ \\
Recife & 553 & $10 \%$ & 697 & $11 \%$ & 657 & $8 \%$ & 539 & $5 \%$ & 340 & $5 \%$ & 631 & $6 \%$ & 523 & $4 \%$ & 509 & $4 \%$ \\
Outros & 499 & $9 \%$ & 919 & $14 \%$ & 897 & $11 \%$ & 966 & $8 \%$ & 318 & $5 \%$ & 343 & $3 \%$ & 582 & $5 \%$ & 397 & $3 \%$ \\
BRASIL & 5.420 & $100 \%$ & 6.362 & $100 \%$ & 8.367 & $100 \%$ & 11.914 & $100 \%$ & 6.465 & $100 \%$ & 11.123 & $100 \%$ & 12.713 & $100 \%$ & 12.914 & $100 \%$ \\
\hline
\end{tabular}

Fonte: elaborado a partir de UNICA (2004) 
A Figura 13 mostra as exportações brasileiras de açúcar acumuladas das safras 99/00, 00/01, 01/02 e 02/03 no período de safra do Centro-Sul, região responsável por cerca de $80 \%$ das exportações nacionais nestas safras. Os dados indicam que de maio a setembro destas safras (exceto a atípica safra 00/01), aproximadamente 50\% do açúcar brasileiro já havia sido exportado, e praticamente $90 \%$ da safra já havia saído do país no mês de janeiro. O período que se estende de maio a setembro coincide com o período crítico de escoamento das exportações de soja, influenciando nos custos logísticos para movimentação dos produtos.

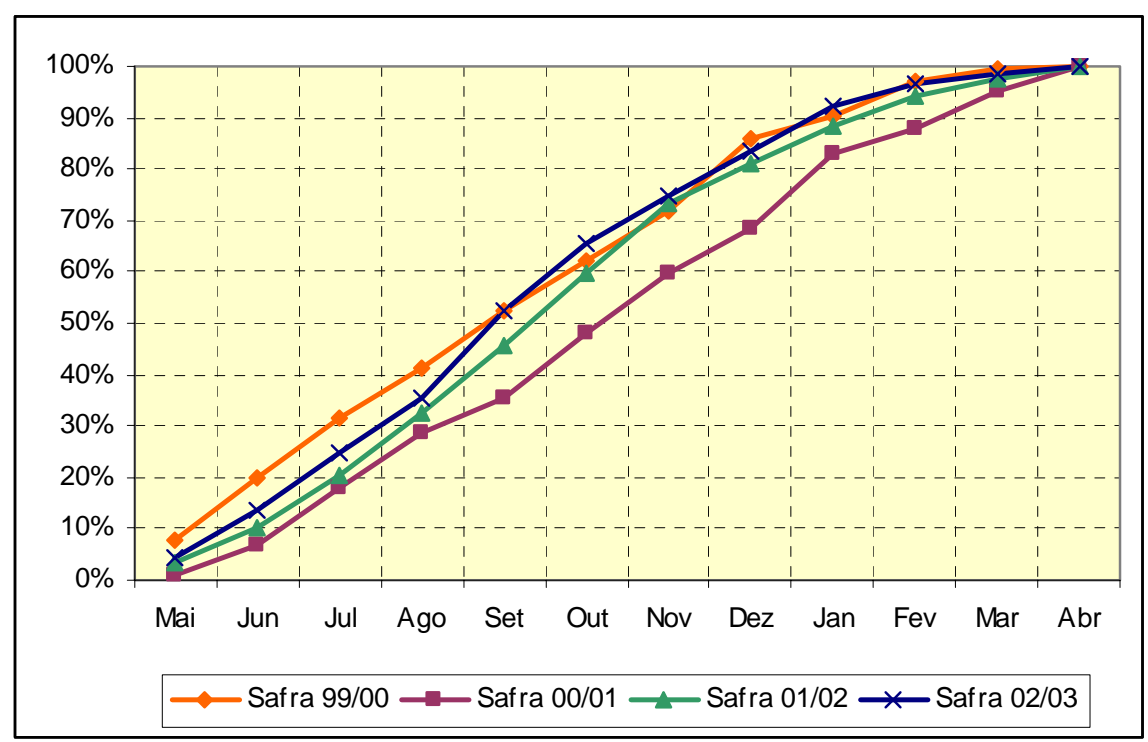

Figura 13 - Exportações acumuladas de açúcar

Fonte: elaborado a partir de UNICA (2004)

O crescente volume de açúcar para exportação gera um aumento na demanda por transporte, armazenagem e estruturas portuárias. Essa demanda é pressionada também pela produção de grãos que vem batendo recordes nos últimos anos e que geram necessidades por estruturas semelhantes. 
Este crescimento contrasta com os níveis de investimentos realizados em melhorias e aumento de capacidade de infra-estrutura para escoamento dos produtos. Apesar de crescentes, estes investimentos ainda estão aquém do ideal e a diferença entre o aumento da oferta de açúcar e grãos e o crescimento da oferta de estrutura para escoamento destes produtos pode implicar aumento de preços nos mercados de fretes, armazéns e tarifas portuárias ou até mesmo no chamado "apagão logístico", termo que tem sido utilizado indicando a falta de infra-estrutura logística para sustentar o aumento das exportações brasileiras, em analogia à escassez de oferta de energia ocorrida em 2001 no Brasil.

Neste sentido, a próxima seção busca documentar os aspectos históricos que influenciaram a composição atual da matriz de transportes de carga brasileira e explicita as condições atuais do setor no Brasil, além de detalhar as características do setor ferroviário brasileiro.

\subsection{A logística no setor agrícola brasileiro}

O conceito de "logística" tem sua origem no ambiente militar da segunda guerra mundial e, segundo Russel (2000), migrou nos anos 70 para o setor empresarial, com objetivo de aplicar os princípios da logística militar para distribuição física de produtos aos consumidores finais. Recentemente, o setor privado passou a ver a logística como um componente importante da cadeia de suprimentos.

Russel (2000) apresenta várias definições de logística, dentre as quais destaca-se: "obtenção do produto correto, para o cliente correto, na quantidade correta, na condição correta, no lugar correto, no tempo correto, e ao custo correto (os chamados sete C's da logística)" e também "determinação dos requisitos de material, compras, transportes, gerenciamento de estoques, armazenagem, movimentação e manuseio de materiais, embalagem, estudos de localização de instalações, gerenciamento da informação, atendimento a clientes e todas as outras atividades relacionadas ao apoio 
material para clientes internos (manufatura) e para com produtos acabados para clientes externos (varejo)".

Este trabalho está focado na logística interna do açúcar para exportação, abrangendo as atividades que ocorrem durante o período que se estende do momento em que o açúcar é produzido na usina até o momento que ele é posto no navio. Neste sentido, especificar-se-á neste estudo as atividades logísticas referentes ao transporte e à armazenagem do açúcar, especialmente no estado de São Paulo. Neste contexto, faz-se necessário entender melhor a situação atual do país nestes setores e, para isso, serão apresentados panoramas gerais do transporte e da armazenagem de produtos agroindustriais no Brasil nas seções 2.2.1 e 2.2.2.

\subsubsection{Especificidades das diferentes modalidades de transporte}

Segundo Caixeta-Filho et al. (2001), o transporte desempenha funções importantes na sociedade, quais sejam a de disponibilizar produtos, integrar e expandir mercados, permitir a concorrência entre bens produzidos em locais distintos, influi nos custos das mercadorias, na especialização geográfica e na renda da terra. Portanto, reduções nos custos de transporte têm efeito direto no custo dos bens tanto na comercialização quanto na compra de insumos. $\mathrm{O}$ transporte é fundamental também no desenvolvimento econômico, pois seu desenvolvimento corre em paralelo ao desenvolvimento industrial.

Conforme Nazário, Wanke e Fleury (2000), são cinco os modais de transporte básicos: o ferroviário, o rodoviário, o aquaviário, o dutoviário e o aéreo, cada qual com características peculiares. $\mathrm{O}$ transporte ferroviário tem altos custos fixos com equipamentos, terminais, vias férreas etc. e custo variável baixo (combustível, manutenção etc.); o rodoviário possui baixos custos fixos (rodovias construídas com fundos públicos) e níveis médios de custo variável. Já o aquaviário possui níveis médios de custo fixo (navios e equipamentos) e custo variável baixo, pois tem capacidade de 
transportar grandes quantidades. O transporte dutoviário tem o custo fixo mais elevado devido a custos de direitos de acesso, construção, controle das estações e capacidade de bombeamento, porém, em compensação, possui os menores custos variáveis, pois praticamente não há custos com mão-de-obra; o transporte aeroviário possui altos custos fixos com aeronaves, manuseio e sistemas de carga e altos custos variáveis (combustível, mão-de-obra, manutenção etc.).

Para complementar a caracterização, a Tabela 5, elaborada a partir dos referidos autores, com pontuações ordinais (neste caso, quanto menor, melhor) para as características referentes aos diferentes modais.

Nazário, Wanke e Fleury (2000) definem os atributos que aparecem na Tabela 5 como se segue: velocidade (ou transit time) refere-se ao tempo que a carga permanece no percurso, a disponibilidade é a flexibilidade do transporte em atender ponta a ponta, a confiabilidade é o nível de capacidade do modal de atender às programações de entrega esperadas. Já o atributo capacidade indica a possibilidade de atender diferentes tipos e tamanhos de carga e a freqüência está relacionada à quantidade de movimentações programadas.

Os custos de transporte são baseados nos custos fixos e variáveis específicos de cada modalidades e nas condições de oferta e demanda do mercado de transporte. Os atributos de cada modalidade são levados em consideração pelas empresas ao fazerem relações de custo-benefício e decidirem o tipo de transporte que será utilizado para movimentação de seus produtos. Nota-se que o transporte rodoviário, no geral, apresenta-se como uma alternativa de destaque e a preferência por este tipo de modal pode ser, segundo os autores, parcialmente explicada por estas características. 
Tabela 5. Características operacionais relativas por modal de transporte

\begin{tabular}{lccccc}
\hline $\begin{array}{l}\text { Características } \\
\text { operacionais }\end{array}$ & Ferroviário & Rodoviário & Aquaviário & Dutoviário & Aéreo \\
\hline Velocidade & 3 & 2 & 4 & 5 & 1 \\
Disponibilidade & 2 & 1 & 4 & 5 & 3 \\
Confiabilidade & 3 & 2 & 4 & 1 & 5 \\
Capacidade & 2 & 3 & 1 & 5 & 4 \\
Freqüência & 4 & 2 & 5 & 1 & 3 \\
Resultado & 14 & 10 & 18 & 17 & 16 \\
\hline
\end{tabular}

Fonte: Nazário, Wanke e Fleury (2000)

As modalidades de transporte utilizadas para movimentação de produtos agrícolas para exportação apresentam especificidades com relação aos atributos acima mencionados, cada qual com suas vantagens e desvantagens. Caixeta-Filho et al. (2001) apresentam-nas da seguinte maneira: o transporte rodoviário é bastante flexível, permitindo o atendimento "porta-a-porta", ressaltando-se, como já citado, seus baixos custos fixos e custos variáveis altos; o transporte ferroviário tem altos custos fixos e baixos custos variáveis, além de ser pouco flexível. Já o fluvial, tende a movimentar cargas de menor valor agregado, a longas distâncias e a baixa velocidade e tem o menor consumo de combustível dentre as modalidades apresentadas. Os autores destacam ainda que as modalidades ferroviária e hidroviária devem estar sempre conjugadas a outras modalidades para que a origem e o destino sejam atingidos.

De acordo com a ASLOG ${ }^{14}$ (1997) citada por Caixeta-Filho et al. (2001, p.63), "o transporte rodoviário seria recomendável para distâncias inferiores a $500 \mathrm{~km}$; o modal ferroviário seria mais indicado para distâncias entre 500 e 1200 km; e o hidroviário, para distâncias superiores a 1200 km”. Os autores analisaram os dados do Sistema de Informações de Fretes para Cargas Agrícolas (SIFRECA) e concluíram que para longas distâncias (acima de $500 \mathrm{~km}$ ) o frete unitário (US\$ / $\mathrm{t}$ x km), conhecido

\footnotetext{
${ }^{14}$ ASSOCIAÇÃO BRASILEIRA DE LOGÍSTICA (ASLOG). Logística’97. / Apresentado à Conferência Anual da Associação Brasileira de Logística, São Paulo, 1997 /
} 
também como momento de transporte, da modalidade ferroviária foi $36 \%$ inferior ao rodoviário enquanto que o frete hidroviário apresentou-se 58\% menor que o rodoviário e $35 \%$ menor que o ferroviário.

As especificidades de cada modalidade de transporte apresentadas mostram que a utilização do transporte ferroviário para escoamento do açúcar a granel para exportação pode ser uma opção bastante interessante. A fim de aproveitar as vantagens intrínsecas a cada modalidade, a intermodalidade surge como uma alternativa aparentemente viável ao transporte rodoviário. A análise dos resultados deste trabalho poderá dar indicações de quão viável é a intermodalidade e para quais usinas esta alternativa se mostra adequada, respeitando determinadas condições.

Destaca-se que o presente estudo tem como pano de fundo um ambiente bastante favorável, onde tanto o mercado de açúcar quanto o ferroviário estão em período de crescimento. Alterações bruscas na dinâmica destes mercados podem afetar os resultados deste trabalho, mas não invalida sua importância.

\subsubsection{Breve histórico da matriz de transporte de carga brasileira}

Os esforços relativamente recentes no sentido de promover o desenvolvimento da infra-estrutura logística do país datam do início da década de 50 e, com Plano de Metas no governo Juscelino, isso de certa forma se concretiza. Segundo Lessa (1983), o plano estava focado na industrialização do país e incluía, além de investimentos nos setores de energia, bens intermediários e equipamentos, uma remodelação do sistema de transporte de carga e passageiros. Para tanto, o governo federal mobilizou recursos destinados ao estabelecimento de uma infra-estrutura viária integrada e moderna, permitindo a entrada da indústria automobilística européia e norteamericana no país para a produção do material de transporte necessário à renovação e ampliação da frota rodoviária. 
Lessa (1983) afirma que do total de investimentos previstos pelo Plano de Metas entre 1957 e 1961, cerca de 30\% destinava-se ao setor de transportes. O Plano previa investimentos no reequipamento do sistema ferroviário, na ampliação e pavimentação das rodovias e na melhoria dos portos e modernização da frota comercial.

O programa de reequipamento ferroviário concentrava todos os recursos do setor na melhoria das condições do sistema já existente (compra de locomotivas, vagões e manutenção das vias de maior tráfego), uma vez que o conceito de ferrovia como meio de ampliação de fronteira agrícola foi substituído pelo de rodovia de penetração. As metas para o setor não foram integralmente cumpridas devido a problemas de financiamento.

Contrastando com o setor ferroviário, no qual não foram obtidos brilhantes resultados, o setor rodoviário cresceu vertiginosamente em extensão e qualidade, principalmente no que diz respeito a investimentos em rodovias federais e estaduais. A extensão dessas cresceu 48\% (a rede pavimentada cresceu 351\%) no período de 1955 a 1956, enquanto o ferroviário cresceu apenas 3,2\% entre 1955 e 1960.

No tocante ao transporte marítimo, o Plano de Metas previa investimentos relacionados ao aumento da frota mercante e à ampliação e equipamento dos portos. Houve êxito na ampliação da frota e um parcial reaparelhamento dos serviços portuários.

A opção rodoviária que caracterizou a evolução do sistema nacional de transportes é anterior ao período de vigência do Plano de Metas e do estabelecimento da indústria automobilística no Brasil. Com o decreto-lei de 1945 que criou o Fundo Rodoviário Nacional e gerou recursos para as rodovias a partir da taxação sobre combustíveis líquidos, deu-se início a era "rodoviarista".

Segundo Gazeta Mercantil (2000), em 1950 o transporte de carga rodoviário já era líder no Brasil, porém, não era uma liderança absoluta: o caminhão transportava $38 \%$ da carga movimentada, rivalizando com a cabotagem, 32,4\%, e a ferrovia, $29,2 \%$. Havia um equilíbrio entre os modais. O impulso da indústria de caminhões e a 
estatização das ferrovias no final da década de 50, além da burocracia portuária, deram forças para o avanço do "rodoviarismo".

A produção em grande quantidade de asfalto pela Petrobrás, inaugurada em 1954, e da indústria automobilística brasileira em 1957, fez com que o transporte rodoviário passasse a ocupar, segundo a Gazeta Mercantil (2000), a dianteira da matriz de transporte de cargas brasileira. Na segunda metade da década de 60, a ferrovia, de 29,2\% de participação em 1950 passou a uma participação modal na matriz em torno de $15 \%$, quando chegou ao ponto mais baixo. A cabotagem, igualmente, passou de $32,4 \%$ das cargas em 1950 para cerca de $15 \%$.

Melo e Fonseca (1981) ressaltam que o transporte rodoviário no Brasil não veio complementar o sistema de transportes existentes, mas sobrepor-se a ele; a construção das estradas de rodagem não foi feita como complemento das ferrovias e da navegação ou como ligação de centros onde não existem outros meios de transporte. $\mathrm{O}$ critério adotado no Brasil foi o de acompanhar as demais vias existentes, disto resultando não uma complementação, mas uma concorrência entre os meios de transporte, com poucas vantagens para a economia nacional.

Na realidade, neste período observou-se a internalização de um padrão de transportes não adequado a fim de responder à demanda colocada pela urbanização e pela industrialização, particularmente no que tange ao transporte ferroviário, que havia cumprido um papel importante na economia cafeeira, mas que nunca havia constituído uma rede coesa e nacional de estradas de ferro, sendo ao contrário, um agrupamento de redes locais isoladas, dotadas de diferentes sistema de bitolas, engates e freios.

Melo e Fonseca (1981) afirmam que o transporte rodoviário passa a cumprir o papel de infra-estrutura urbana e industrial inexistente e não passou por um processo de acumulação econômica industrial e modernização do setor de transportes como o foi nas nações mais desenvolvidas. 
A especificidade da evolução do sistema de transportes no Brasil, apresentando problemas de ordem técnica, financeira e institucional, é análoga à especificidade da própria industrialização, com a produção de bens de consumo duráveis e não-duráveis antecedendo a produção no país de bens intermediários e de capital.

Gazeta Mercantil (2001) expõe que na década de 80, a situação do setor ferroviário, que já não era boa, deteriora-se ainda mais com a redução das taxas de crescimento e investimentos no país e do aumento dos preços e das tarifas públicas, tendo em vista a conjuntura inflacionária daquela década. Tornara-se evidente, portanto, o sucateamento do sistema ferroviário nacional, que já estava comprometendo inclusive as operações das grandes empresas usuárias desse sistema.

Desta forma, a escassez de recursos federais não permitiu a reversão do quadro, e novamente a operação das ferrovias foi transferida à iniciativa privada, iniciando um processo de desestatização das malhas da Rede Ferroviária Federal (RFFSA) e da Ferrovia Paulista (Fepasa). O objetivo era tornar os serviços de transporte ferroviário mais eficientes, sem, contudo, prejudicar as finanças públicas (Gazeta Mercantil, 2001).

A possibilidade da ferrovia desempenhar um papel de destaque na matriz de transporte brasileira motivou e norteou a privatização de serviços de transporte ferroviário no Brasil. As concessões foram importantes no sentido de desmanchar as onerosas organizações que operavam e administravam o sistema, contribuindo para ganhos significativos de produtividade.

A partir da segunda metade da década de 90, com a privatização das ferrovias e a modernização dos portos, efetivamente começou a se esboçar uma concorrência frente ao amplo predomínio exercido pelo transporte rodoviário. Além do surgimento de modais competidores, a concorrência com o transporte rodoviário vem sendo estimulada pelo encarecimento dos custos operacionais (pedágio, diesel, seguro etc.). A carga de grande volume, movimentada em médias e longas distâncias, tal como o açúcar, tende a migrar para transportes alternativos ao rodoviário. 


\subsubsection{Situação atual da matriz de transporte de carga brasileira}

Segundo o Centro de Estudos em Logística do Instituto de Pós-Graduação em Administração da Universidade Federal do Rio de Janeiro (CEL/COPPEAD) (2002), o setor de transportes no Brasil apresenta características que podem ser geradoras de problemas graves num futuro próximo. Fato como a alta dependência do setor rodoviário (com frota de idade média avançada - cerca de 17,5 anos - e com quase $80 \%$ de suas rodovias em condições ruins ou péssimas), agravado pelas dificuldades para desenvolvimento de outros modais, tornam o sistema ineficiente e o país bastante vulnerável a colapsos como o "apagão logístico". A insuficiência de infra-estrutura ferroviária, cujas locomotivas estão com idade média também bastante avançada (em média, 25 anos), a pouca utilização da modalidade aquaviária e a baixíssima disponibilidade de terminais multimodais tornam o problema ainda mais grave.

A matriz de transporte de carga brasileira está representada na Figura 14 que mostra a participação preponderante do modal rodoviário. Além deste aparente desbalanceamento da matriz de transporte de carga brasileira, há ainda uma insuficiência de infra-estrutura de transporte, em termos de extensão e qualidade das vias quando comparado com a matriz de outros países em desenvolvimento e com grandes extensões territoriais (vide Figura 15). Segundo o CEL/COPPEAD (2002), o Brasil possui uma densidade de $26,4 \mathrm{~km}$ de infra-estrutura por cada $1000 \mathrm{~km}^{2}$ de área, enquanto que a densidade de países como Canadá, México e China são, respectivamente, 48,3 km/ 1000 $\mathrm{km}^{2}, 57,2 \mathrm{~km} / 1000 \mathrm{~km}^{2}$ e $38,3 \mathrm{~km} / 1000 \mathrm{~km}^{2}$.

A Figura 16 mostra que apesar da densidade do transporte rodoviário ser a maior, dentre as modalidades no Brasil, ela não é satisfatória, pois está bastante concentrada no litoral do país, principalmente das regiões Sudeste e Sul, além de possuir cerca de $80 \%$ de seus pavimentos com mais de 10 anos. 


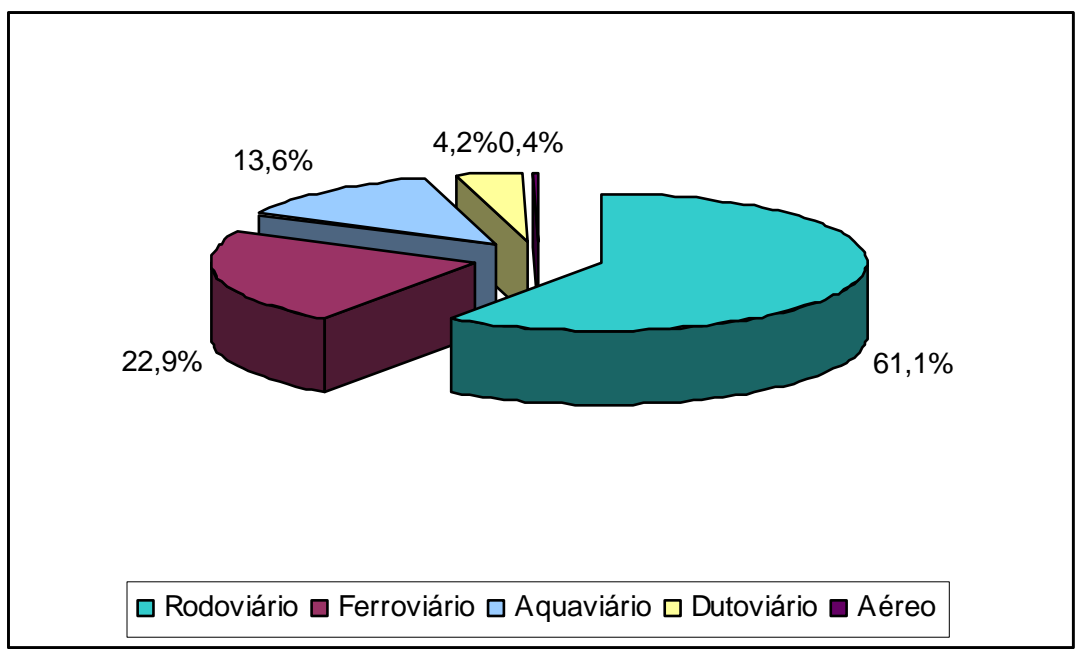

Figura 14 - Participação modal no transporte de cargas, 2003

Fonte: Brasil (2004)

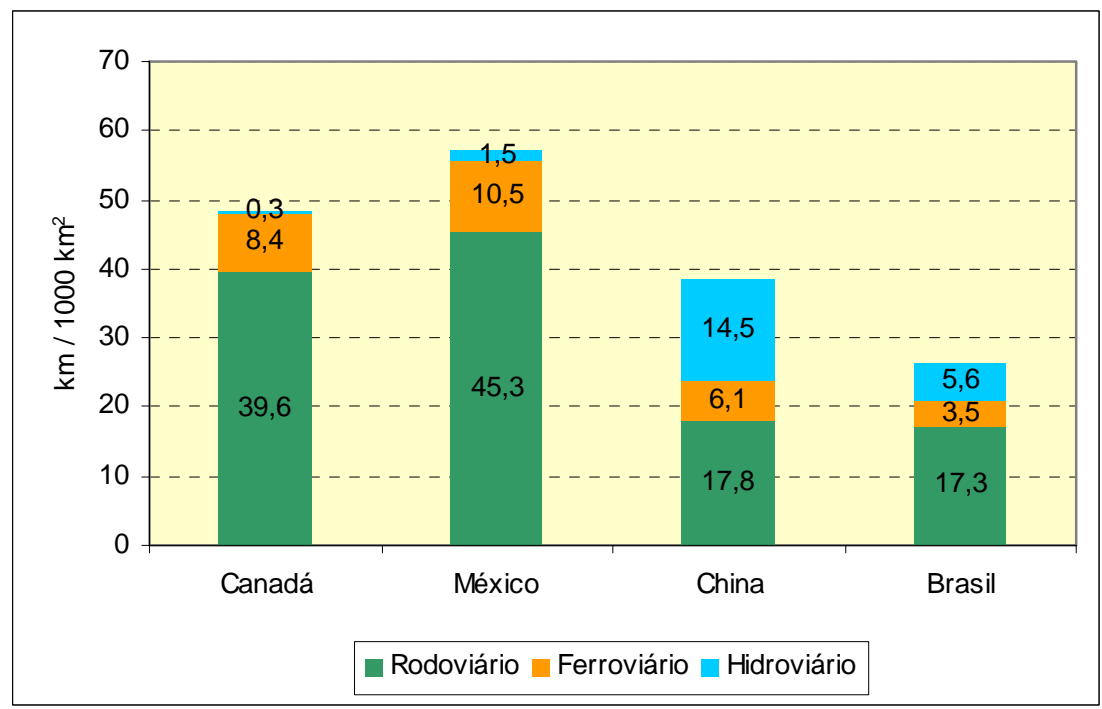

Figura 15 - Densidade de transporte

Fonte: CEL/COPPEAD (2002) 


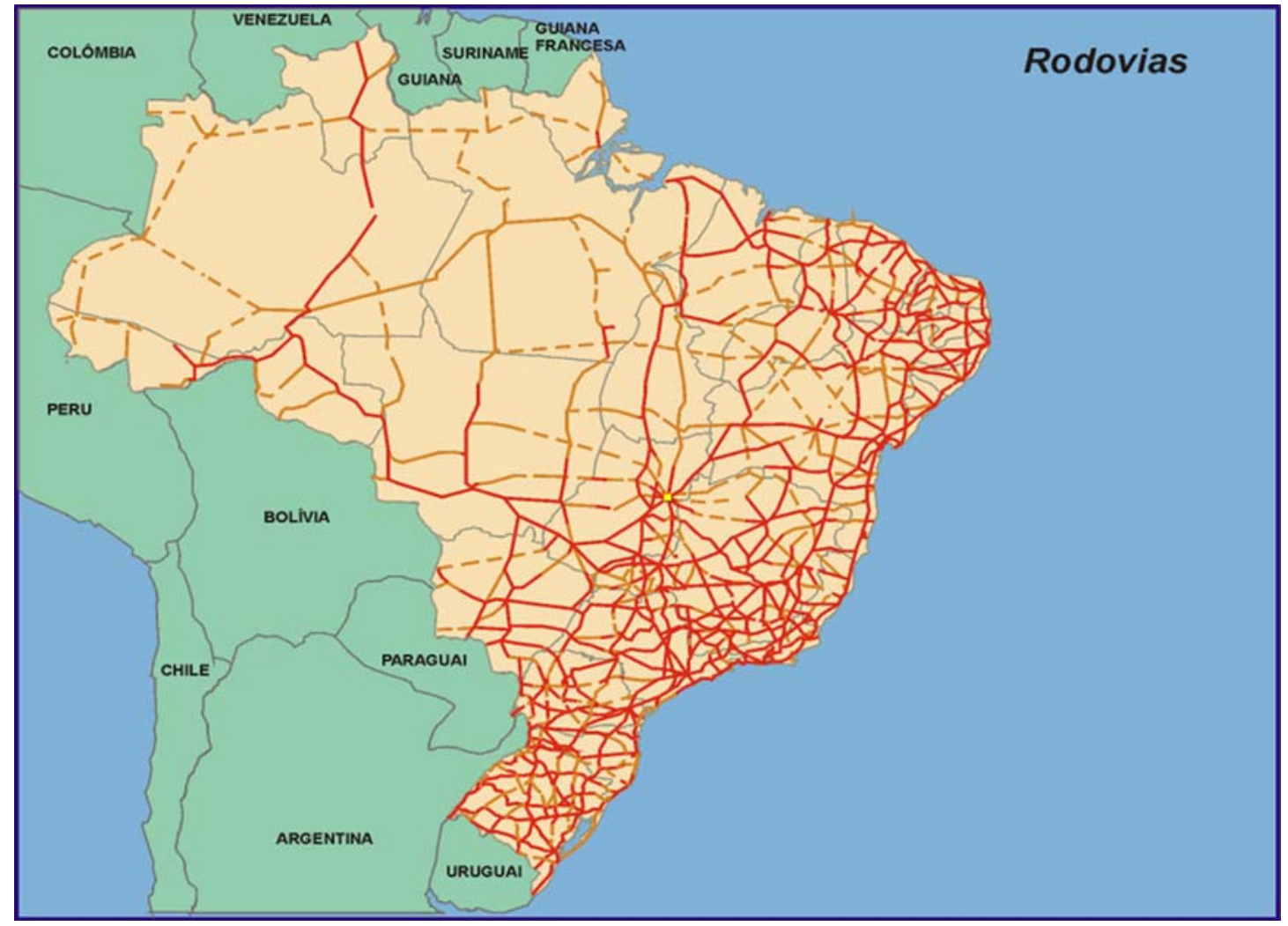

Figura 16 - Malha rodoviária brasileira, 2003

Fonte: Brasil (2004)

O diagnóstico do CEL/COPPEAD (2002) sobre a infra-estrutura logística brasileira indica que os problemas de deficiências na regulação, de custo de capital elevado e nas políticas de investimento dos governos levaram o país a uma dependência exagerada do modal rodoviário. Esta dependência torna-se um problema quando se leva em consideração as dimensões continentais do Brasil e sua infra-estrutura rodoviária precária e insuficiente (com uma produção que se interioriza cada vez mais, onde o problema é ainda mais grave), a sua baixa produtividade, sua pequena eficiência energética, seu alto índice de emissão de poluentes, seu baixo nível de segurança e suas condições concorrenciais complicadas. Neste mercado predominam agentes autônomos, caminhoneiros que tem seu próprio veículo e não estão ligados a nenhuma 
transportadora ou cooperativa, e há alta oferta de serviço o que acaba afetando negativamente os preços e fazendo com que o setor entre em um ciclo vicioso.

A Figura 17 mostra o ciclo vicioso em que se encontra o mercado de transporte rodoviário de carga no Brasil. O setor tem baixas barreiras à entrada (basta ter carteira de habilitação e um caminhão) e altas barreiras à saída (caracterizadas pela dificuldade de inserção no mercado de trabalho devido ao baixo nível educacional dos caminhoneiros), o que implica um excesso de oferta de serviço e conseqüente queda de preços.

“O valor pago pelos fretes rodoviários é muito baixo em comparação com os custos incorridos. Este frete artificialmente baixo é um problema porque compromete a saúde do setor, impede o crescimento de outros modais e gera externalidades negativas para a sociedade" (CEL/COPPEAD, 2002, p.33).

Ao remunerar insuficientemente os agentes, o baixo frete resulta em diminuição de manutenção dos caminhões, jornada excessiva de trabalho, excesso de carga e inadimplência fiscal. As estratégias adotadas pelos autônomos para tentar compensar suas perdas (por exemplo, trafegar com excesso de cargas e de velocidade) acabam por aumentar ainda mais a capacidade instalada, reduzindo ainda mais o preço, reiniciando-se desta forma o círculo vicioso. 


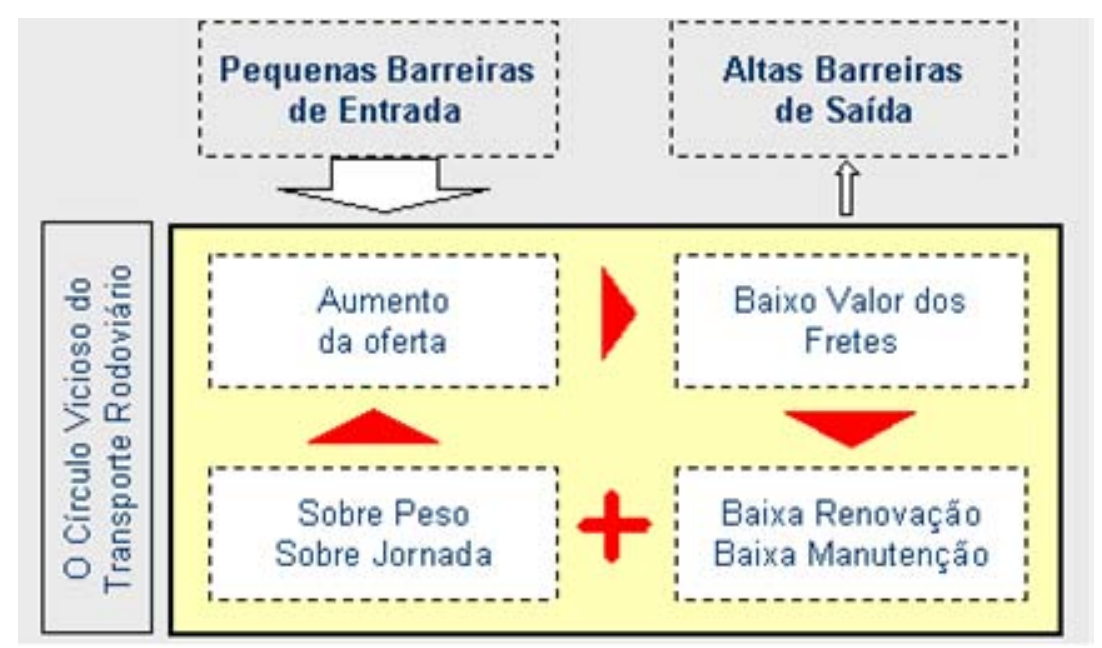

Figura 17 - Círculo vicioso do transporte rodoviário Fonte: CEL/COPPEAD (2002)

\subsubsection{O transporte ferroviário de cargas no Brasil}

Segundo Castro (2001), o setor ferroviário encontra-se atualmente no terceiro ciclo de evolução institucional. Para o autor, o primeiro ciclo refere-se à origem do setor. Neste momento, as primeiras estradas foram financiadas principalmente por capital inglês entre 1852 e 1900, através de concessões do governo e garantias de taxas de retorno atraentes sobre o capital. Em São Paulo os cafeicultores financiaram suas próprias estradas de ferro, com exceção da inglesa EF Santos-Jundiaí, que ficou com o monopólio do transporte para a descida da Serra do Mar.

O segundo ciclo tratou do processo de nacionalização das ferrovias, quando ocorreram novas implantações financiadas por empréstimos estrangeiros garantidos pelo Tesouro. Em 1929, o Estado, segundo Castro (2001), obtinha 67\% das companhias ferroviárias brasileiras e era responsável pela administração de $41 \%$ da rede (de cerca de 10 mil km).

Em 1957, foi criada a Rede Ferroviária Federal (RFFSA) com o objetivo de sanear as perdas financeiras acumuladas pelas ferrovias sob administração pública. A 
criação da RFFSA marca o início da fase de estabilidade do segundo ciclo. Em 1971, criou-se a FEPASA, que acabou por normalizar a contribuição de São Paulo para com manutenções de serviços antieconômicos e por absorver encargos previdenciários de empregados estatutários, encerrando praticamente a atuação privada na prestação desse serviço público.

O autor afirma que a desestatização do setor ferroviário, nascida com a crise dos anos 80, marca o terceiro ciclo. A desestatização foi motivada principalmente pelo fato de haver um espaço significativo para a expansão deste modal na matriz de transporte brasileira.

Em 1984, as dívidas da RFFSA são transferidas para o Tesouro Federal e são lançadas as bases para a criação da Cia. Brasileira de Trens Urbanos, que absorve as divisões de transporte de passageiro de subúrbio da RFFSA. "A separação dos serviços de carga e passageiros, a imputação do ônus de serviços antieconômicos à União e a almejada liberdade tarifária anunciam a nova fase que tem importante marco em 1992, quando a RFFSA foi incluída no Programa Nacional de Desestatização, que abriu a oportunidade de rever o funcionamento do sistema ferroviário brasileiro, em particular sua regulamentação" (Castro, 2001, p.3), e propiciou o início da transferência de suas malhas para a iniciativa privada, durante um período de 30 anos, prorrogáveis por mais 30. Esse processo também resultou na liquidação da RFFSA, a partir de dezembro de 1999.

Em 1996, estabeleceu-se o novo marco regulamentar nacional do transporte ferroviário, publicado às vésperas do primeiro leilão de privatização das malhas da RFFSA, que apesar de ter suprimido os aspectos irrelevantes dos marcos anteriores, não avançou muito em pontos críticos do setor, tais como tarifas, desativação de ramais antieconômicos, interpenetração e tráfego mútuo e requisitos para habilitação de operador ferroviário, dado que a regulamentação anterior foi concebida para um serviço público com características monopolísticas, portanto praticamente não considerava 
aspectos de política comercial, concorrência de mercado e obrigação de acordos de tráfego mútuo e/ou de acesso de outros operadores.

A privatização das malhas resgatou a importância do modal ferroviário na matriz de transportes através da oferta de serviços mais eficientes. Conforme relata a Gazeta Mercantil (2001), para a promover o processo de privatização da RFFSA a malha foi dividida em cinco grandes lotes. A malha Oeste foi a primeira a ser privatizada, em março de 1996, seguida pela malha Centro-Leste, malha Sudeste e malha Sul, naquele mesmo ano e a Nordeste no ano seguinte, conforme dados da Tabela 6. A desestatização compreendeu também a Ferrovia Tereza Cristina, trecho ferroviário localizado em Santa Catarina, pertencente à RFFSA, além da Fepasa, incorporada à RFFSA em 1997 e privatizada em 1998. As concessionárias funcionam sob regulação da Agência Nacional de Transportes Terrestres (ANTT), incumbida de regular e supervisionar as atividades de prestação de serviços e de exploração da infra-estrutura de transportes exercidas por terceiros.

Segundo a ANTT (2004), em junho de 1997, o governo federal outorgou à Companhia Vale do Rio Doce, no processo de sua privatização, a exploração da Estrada de Ferro Vitória a Minas e da Estrada de Ferro Carajás, utilizadas basicamente no transporte de minério dessa empresa. Além das malhas da RFFSA e das estradas de ferro da Companhia Vale do Rio Doce, a ANTT é responsável pelas seguintes concessões: Ferrovias Norte Brasil S.A. (Ferronorte), Estrada de Ferro Mineração Rio do Norte, Estrada de Ferro Jarí, Estrada de Ferro Amapá, Estrada de Ferro Trombeta, Estrada de Ferro Votorantim, Estrada de Ferro Paraná Oeste (Ferroeste). 
Tabela 6. Concessões resultantes da privatização da RFFSA

\begin{tabular}{lclrr}
\hline \multicolumn{1}{c}{$\begin{array}{c}\text { Malhas } \\
\text { Regionais }\end{array}$} & $\begin{array}{c}\text { Data do } \\
\text { Leilão }\end{array}$ & \multicolumn{1}{c}{ Concessionárias } & $\begin{array}{c}\text { Início da } \\
\text { Operação }\end{array}$ & $\begin{array}{c}\text { Extensão } \\
(\mathrm{Km})\end{array}$ \\
\hline Oeste & 05.03 .96 & Ferrovia Novoeste S.A. & 01.07 .96 & 1.621 \\
Centro-Leste & 14.06 .96 & Ferrovia Centro-Atlântica S.A. & 01.09 .96 & 7.080 \\
Sudeste & 20.09 .96 & MRS Logística S.A. & 01.12 .96 & 1674 \\
Tereza & & & & \\
Cristina & 26.11 .96 & Ferrovia Tereza Cristina S.A. & 01.02 .97 & 164 \\
Sul & & ALL-América Latina Logística do & & \\
Nordeste & 13.12 .96 & Brasil S.A & 01.03 .97 & 6.586 \\
Paulista & 18.07 .97 & Companhia Ferroviária do Nordeste & 01.01 .98 & 4.534 \\
Total & 10.11 .98 & Ferrovias Bandeirantes S.A. & 01.01 .99 & 4.236 \\
\hline
\end{tabular}

Fonte: ANTT (2004)

A malha atual está ilustrada na Figura 18, que traz a malha operada pelas concessionárias das diferentes regiões. 


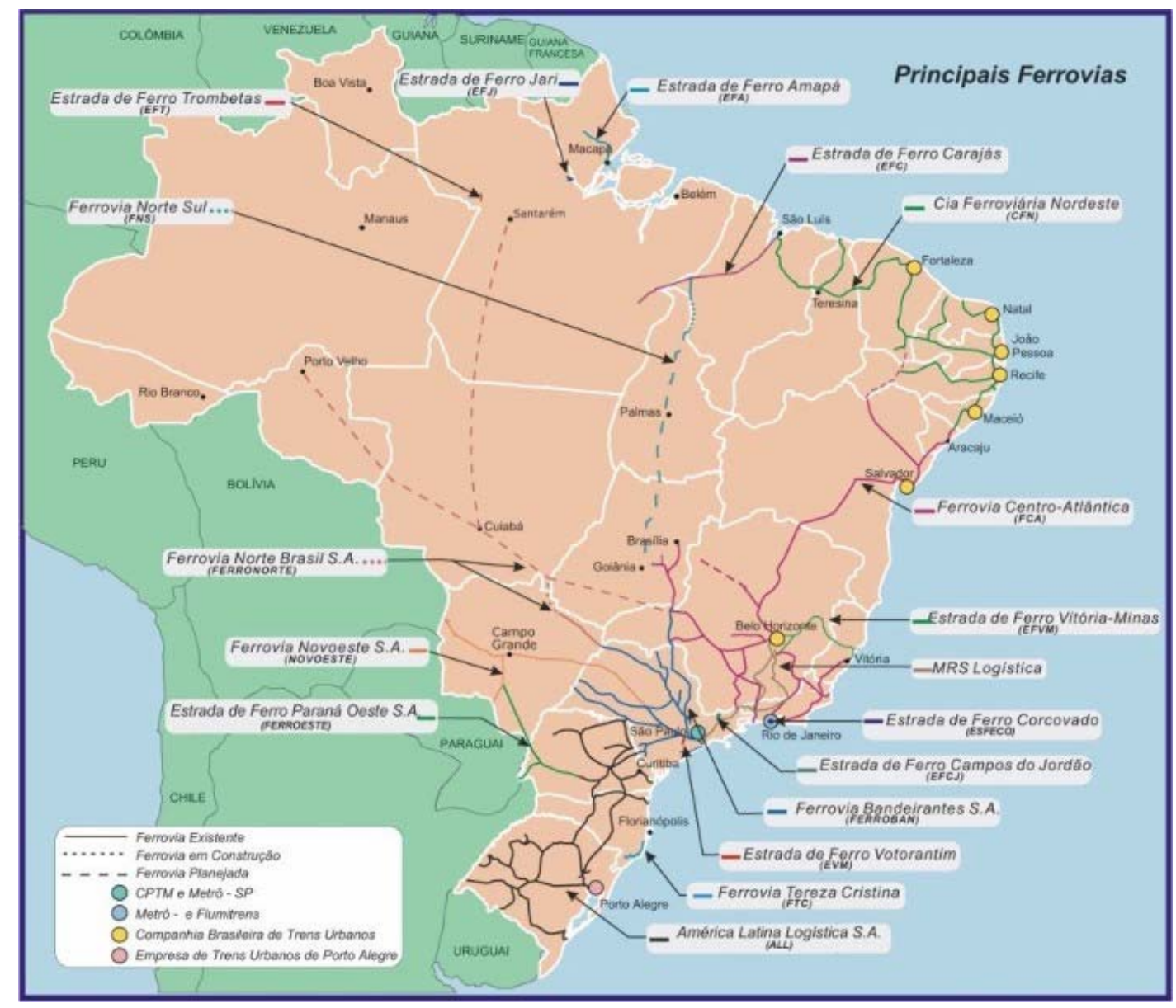

Figura 18 - Malha Ferroviária brasileira, 2003

Fonte: Brasil (2004)

Dos $29.789 \mathrm{~km}$ da malha ferroviária nacional, $28.671 \mathrm{~km}$ foram concedidos à iniciativa privada para exploração dos serviços de transporte de cargas. $\mathrm{O}$ controle das malhas passou, segundo Gazeta Mercantil (2001), a ser exercido predominantemente pelo capital privado nacional, destacando-se na composição acionária dessas empresas grandes usuários do transporte ferroviário de cargas. Além da Companhia Vale do Rio Doce (CVRD), cuja participação no setor já se mostrava acentuada por meio da operação da Estrada de Ferro Vitória-Minas e Carajás, outras empresas como a Companhia Siderúrgica Nacional (CSN) e a Minerações Brasileiras Reunidas (MBR) passaram a atuar no setor. 
O CEL/COPPEAD (2002) relatou que a RFFSA cortou drasticamente os investimentos na malha ferroviária nacional durante os dez anos que antecederam a privatização, passando de um patamar de cerca de R\$ 1,0 bilhão de investimentos anuais, nos primeiros anos da década de 1980 para algo em torno de R $\$ 200$ milhões por ano, na segunda metade da década de 80, e cerca de R $\$ 50$ milhões por ano, entre 1990 e 1995, ano em que teve início o processo de privatização.

Este fato resultou na entrega aos novos concessionários de vias em péssimo estado de conservação, que tem reflexos ainda bastante pesados nos dias de hoje (por exemplo, em alguns trechos, a velocidade média não passa de $10 \mathrm{~km} /$ hora). A entrada de capital privado nas ferrovias promoveu aumento significativo nos investimentos (vide Figura 19). Entre 1997 e 2003, a ANTT (2004) estima que a União investiu R\$ 500 milhões na malha ferroviária nacional enquanto que as concessionárias investiram cerca de R\$ 4 bilhões que contribuíram para recuperar parte da frota sucateada herdada da RFFSA. Como resultado a produção das ferrovias privatizadas a partir de 1997 passa a crescer, conforme ilustrado na Figura 20 e o índice de acidentes cai 55\%, apesar de ainda estar longe de padrões internacionais.

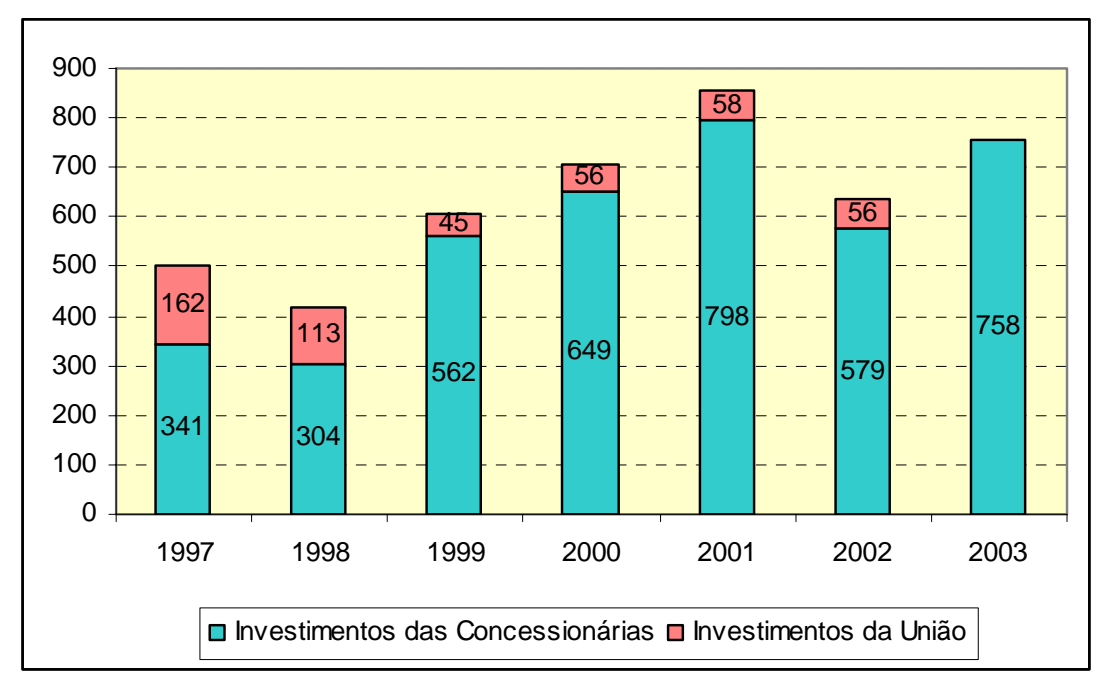

Figura 19 - Investimentos na malha nacional, em R \$ milhões

Fonte: Associação Nacional dos Transportadores Ferroviários (ANTF) (2004) 


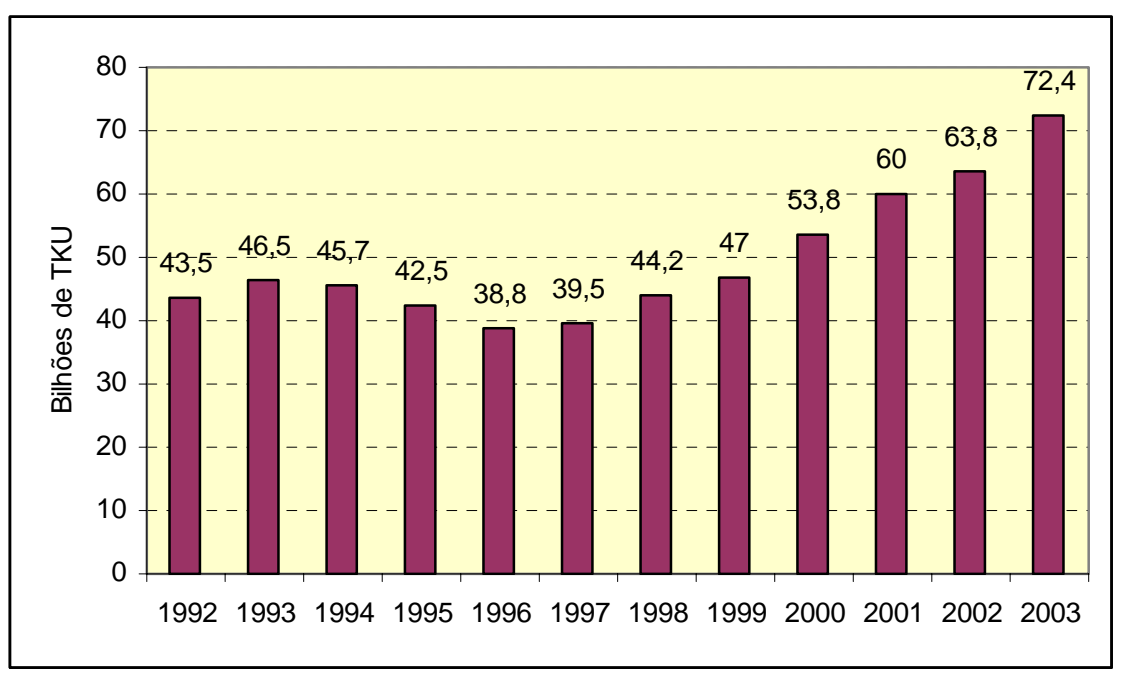

Figura 20 - Produção ferroviária das ferrovias privatizadas, em bilhões de toneladasquilômetro útil (TKU)

Fonte: ANTF (2004)

A ANTF (2004) afirma que para haver um aumento da participação do modal ferroviário na matriz de transporte de carga brasileira para $30 \%$, serão necessários investimentos da União da ordem de $\mathrm{R} \$ 4$ bilhões e de $\mathrm{R} \$ 7$ bilhões por parte das concessionárias nos próximos 5 anos, concentrados na manutenção de via permanente, em vagões e locomotivas.

O investimento em ferrovias exige condições especiais de carência, prazo e taxas de juros. No Brasil, atualmente, somente o BNDES oferece este tipo de financiamento. O governo está apostando em parcerias com o setor privado como estratégia de financiamento para o setor de infra-estrutura, através das chamadas Parcerias Público-Privadas (PPPs), recentemente aprovadas no Congresso Nacional.

Segundo o Brasil (2004a), o Estado brasileiro reconhece seu novo papel de indutor e co-partícipe do crescimento e a necessidade de alocação prioritária de recursos públicos à implementação de políticas sociais, o que implica a definição e o desenvolvimento de mecanismos de financiamento que compatibilizem as necessidades 
de investimentos em infra-estrutura a esta nova realidade, fundamental para o crescimento econômico sustentável. Nesse contexto, cresce a importância do desenvolvimento e implementação de modelos inovadores que estimulem a oferta de serviços de utilidade pública pelo setor privado, segundo o conceito e as metodologias relacionadas às Parcerias Público-Privadas (PPPs), ainda não exploradas inteiramente no Brasil, principalmente pela ausência de um marco legal e institucional apropriado e específico.

Brasil (2004a) define a PPP como uma modalidade de contrato na qual o governo e os agentes privados compartilhariam riscos. A idéia é que o setor privado faça a obra e cobre as tarifas. Como elas serão insuficientes, o governo vai completar a rentabilidade do investidor. As PPPs, segundo Camargo (2004), surgem como uma alternativa aos demais modelos tradicionais como privatização, licitação, concessão etc. (praticamente esgotados) e está em acordo com tendência mundial de flexibilização na contratação de bens e serviços por parte da administração pública.

Portos (2004) traz que dentre os 22 projetos listados no Plano Plurianual de Investimentos (PPA), a prioridade das PPPs seriam investimentos nos portos de Santos, Sepetiba (RJ) e Itaqui (MA), a ferrovia entre as cidades maranhenses de Balsas e Darcinópolis e Estreito (para viabilizar escoamento da soja da região pelo porto de Itaqui), além da rodovia BR-101, trecho sul, entre as cidades de Florianópolis (SC) e Osório (RS).

Enfim, as PPPs podem se configurar uma alternativa interessante para amenizar os problemas de financiamento brasileiro, porém não deve ser visto como instrumento que vai solucionar todas as carências de investimento público no país. No caso das ferrovias, além dos problemas de condições de via e de oferta de transporte, permanecem pendentes as seguintes questões: faixas de domínio da ferrovia, utilização compartilhada das linhas, idade avançada dos ativos (locomotivas e vagões) e ainda a questão da integração operacional deficiente das malhas. 
É neste contexto que o governo federal, através do Ministério dos Transportes, lançou o Plano de Revitalização das Ferrovias que inclui quatro programas (Brasil, 2004). O primeiro é o Programa de Integração e Adequação Operacional das Ferrovias que tem por objetivos reorganizar as concessões e tomar medidas para reestruturação das malhas, criar mecanismos de fiscalização e controle de desempenho das concessionárias. O segundo programa é o de Ampliação da Capacidade dos Corredores de Transporte, cuja meta é aumentar a participação da ferrovia na matriz de transporte de carga brasileira através de investimentos públicos e privados principalmente em via, frota e segurança. O Programa de Expansão e Modernização da Malha Ferroviária objetiva a construção de novos trechos ferroviários com prioridade para complementação dos projetos Ferrovia Norte-Sul, Trasnordestina e Ferronorte. Além destes, há o Programa de Resgate do Transporte Ferroviário de Passageiros, cujo objetivo é criar condições para o retorno desta modalidade no Brasil.

Um outro movimento importante que vem ocorrendo no setor são as parcerias entre clientes e concessionários. O cliente financia a compra ou reforma de vagões e/ou de locomotivas através de adiantamento de fretes; em contrapartida, tem o seu volume de transporte garantido através do estabelecimento de contratos do longo prazo com as ferrovias. Outra alternativa é a do próprio cliente adquirir o ativo e alugálo à ferrovia, também resguardado pelo estabelecimento de contrato de longo prazo. Estes tipos de parcerias foram as grandes responsáveis pelo aumento da demanda de vagões na indústria ferroviária brasileira, conforme mostra a Figura 21. 


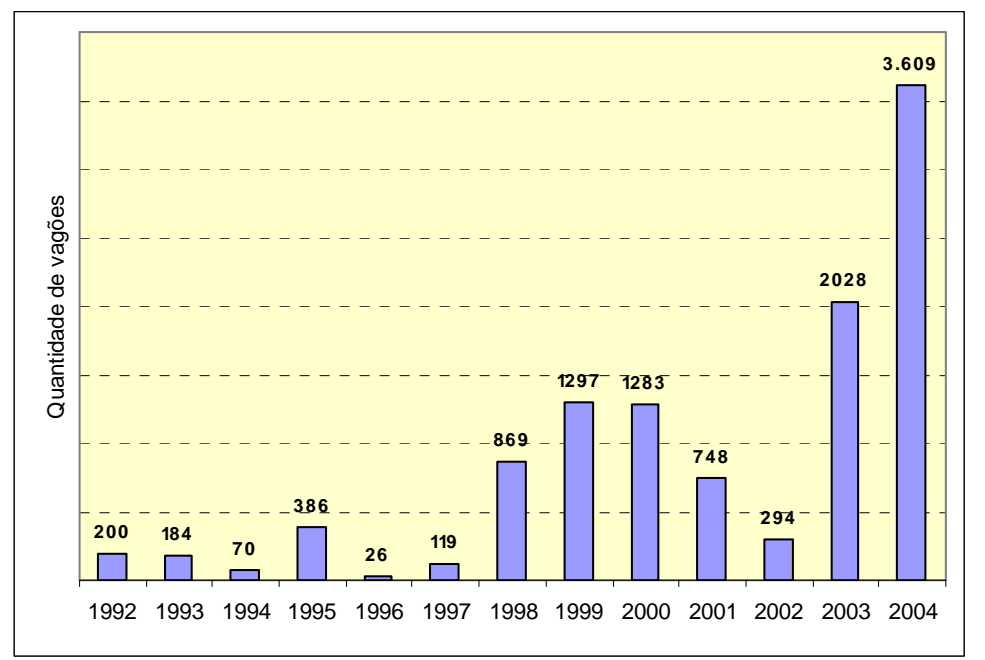

Figura 21 - Produção Brasileira de vagões

Fonte: elaborado a partir da Associação Brasileira da Indústria Ferroviária (ABIFER) (2005)

O investimento de clientes na ferrovia é uma tendência forte entre as companhias para as quais o gasto com transporte tem peso significativo no valor do produto. Alguns casos que saíram na mídia recentemente podem ser citados. Pereira (2005) cita quatro: da Caramuru, da Votorantim, da ADM e da Bunge. O grupo Caramuru, por exemplo, injetou R\$33 milhões na compra de 10 locomotivas e 300 vagões que serão operados pela Brasil Ferrovias (Ferronorte) para exportação de produtos do complexo soja. O montante investido é abatido do valor do frete.

A Votorantim Celulose e Papel (VCP) investiu, juntamente com a concessionária MRS, R\$ 30 milhões na restauração de 24 quilômetros de linha ferroviária entre Jacareí e Mogi da Cruzes, no Estado de São Paulo, e na construção de armazéns. A americana ADM, processadora de soja e milho também aderiu a esse movimento e firmou um contrato com a Brasil Ferrovias. A empresa já investiu US\$ 10 milhões, financiados pelo BNDES, na compra de 140 vagões. A Bunge Alimentos assinou, com a América Latina Logística (ALL), um dos maiores contratos do país que tem duração de 23 anos. Entre 2005 e 2010 serão transportados cerca de 50 milhões de 
toneladas, e mais 220 milhões de toneladas no período de 2010 a 2027. Segundo o acordo, cerca de 3,9 mil vagões serão disponibilizados pela Bunge e as locomotivas, pela ALL.

Brito (2005) cita outro caso que envolve a Bunge Alimentos. A empresa fechou um contrato de 10 anos com a Brasil Ferrovias que prevê a movimentação de 17 milhões de toneladas de produtos agrícolas do complexo soja e a incorporação de ativos rodantes (locomotivas e vagões) ao patrimônio da Ferronorte (Brasil Ferrovias). A garantia da carga permite à empresa ferroviária a operação de leasing para contratação de 374 vagões e 17 locomotivas que serão utilizadas neste transporte. Este será o primeiro caso onde a Brasil Ferrovias atuará como operador logístico, ou seja, fará a gestão de toda a operação logística desde o terminal do interior (Alto Taquari) até o Porto de Santos (Terminal XXIX).

No setor sucroalcooleiro, empresas como Cosan, Cargill, Crystalsev, Copersucar, Sucden, Grupo Coruripe e EDF\&Man também estabeleceram contratos de longo prazo com as concessionárias ferroviárias. Em 2004, por exemplo, a EDF\&Man (responsável por cerca de 15\% das exportações brasileiras de açúcar) fechou um contrato com a Brasil Ferrovias para o transporte anual de 320 mil toneladas até 2010. A empresa inaugurou um terminal de transbordo em Santa Adélia, na região de Catanduva/SP, ao lado da linha da Brasil Ferrovias, para agregar carga das usinas de açúcar da região e movimentá-las via ferrovia até o Porto de Santos. O terminal terá capacidade estática de 45 mil toneladas e será capaz de movimentar cerca de 500 mil toneladas por ano, ou seja, o giro será maior que 10 vezes! A empresa investiu também $\mathrm{R} \$ 10$ milhões no projeto e comprou 4 locomotivas e 88 vagões (Necessidade, 2005 e Brito, 2004).

A Sucden do Brasil e suas sócias, as usinas Aralco de Santo Antonio do Aracanguá-SP e Unialco de Guararapes-SP, investiram um total de US\$ 4 milhões na construção de um terminal rodoferroviário denominado Araçatuba Logística para o escoamento, por ferrovia, do açúcar produzido na região até o porto de Santos (Aralco, 2005). O terminal "Araçatuba Logística” permitirá a estocagem de cerca de 180 mil 
toneladas de açúcar e disponibilizará esta prestação de serviços às unidades produtoras da região e também às outras empresas comerciais exportadoras (tradings) que operam na região. No projeto junto à Novoeste, foram investidos cerca de R 2,5 milhões na aquisição de locomotivas e vagões e, em contrapartida, o grupo terá abatimento no custo do frete nos próximos anos. Aralco (2005) afirma que a utilização do transporte ferroviário em substituição ao rodoviário para o transporte de açúcar garantiu às usinas uma redução de $20 \%$ no custo do frete na safra $03 / 04$.

A existência do terminal para armazenagem e transbordo e composições dedicadas permite prever e planejar as operações, conforme opinião de agente do setor citado por Brito (2004). O volume constante de transferência do interior para o porto evita a necessidade de contratos spot para frotas de caminhões que acarretam em altos preços pagos devido à eventual urgência de transporte para atender demanda do porto.

Com todos estes investimentos por parte dos clientes as ferrovias brasileiras estão seguindo uma tendência já observada nos Estados Unidos, onde as operadoras ferroviárias têm apenas um terço dos ativos, o restante foi financiado pelos usuários. Atualmente 23\% dos ativos rodantes da Brasil Ferrovias são de terceiros (Brito, 2005).

No contexto da malha ferroviária paulista, a Brasil Ferrovias (holding das empresas Ferroban, Ferronorte e Novoeste) é a empresa ferroviária de maior importância em termos de área de influência, pois corta o estado de leste a oeste e tem acesso ao porto de Santos, por isso sua importância para o complexo sucroalcooleiro é muito grande. A Figura 22 mostra a sua área de atuação e o Anexo A mostra o mapa das ferrovias que cortam o estado e os principais pontos de carregamento atuais da Brasil Ferrovias. 


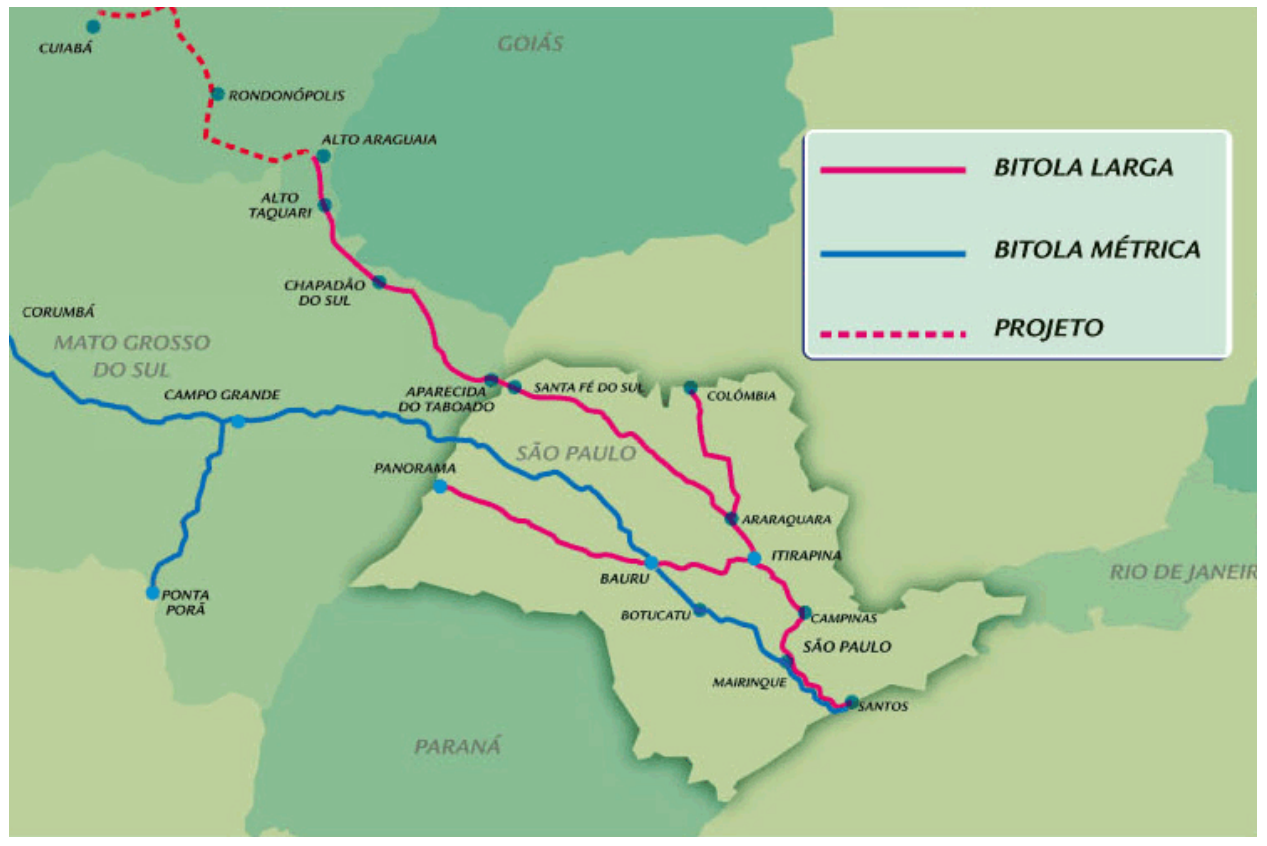

Figura 22 - Área de atuação da Brasil Ferrovias

Fonte: Brasil Ferrovias (2005)

A holding controla atualmente as ferrovias Ferroban, Ferronorte e Novoeste e são operadas através de dois corredores, um de bitola larga e outro de bitola métrica (Brasil Ferrovias, 2005). O primeiro é formado por três trechos principais: linha tronco, ligando Alto Araguaia-MT, ao porto de Santos; trecho que interliga a hidrovia do rio Paraná, na cidade de Panorama-SP, à linha tronco em Itirapina e trecho que interliga a cidade de Colômbia, na divisa de Minas Gerais, à linha tronco na cidade de Araraquara. Já o corredor de bitola estreita, inicia-se em Corumbá e Ponta Porã-MS, passando por Campo Grande-MS, Bauru-SP e Sorocaba-SP, interligando-se ao corredor de bitola larga no município de Mairinque-SP. A partir de Mairinque, os trens podem acessar o porto de Santos, a cidade de Campinas e o pólo petroquímico de Paulínia, utilizando $3^{\circ}$ trilho que possibilita o tráfego de trens de bitola métrica no Corredor de Bitola larga.

Além desta, três outras ferrovias atuam em São Paulo: ALL, FCA e MRS. A ALL opera a via ao sul do estado, mas não tem acesso ao Porto de Santos, a Companhia 
Vale do Rio Doce (controladora da FCA) opera na região de Ribeirão Preto e acessa o Porto através de um acordo com a Ferroban. Já a MRS atua no extremo leste do estado (interliga os estados de Minas Gerais, São Paulo e Rio de Janeiro) e atualmente tem o monopólio do acesso ferroviário de bitola larga à margem direita do Porto de Santos ${ }^{15}$.

A Figura 23 apresenta os volumes de açúcar operados pela Brasil Ferrovias. O volume total de açúcar transportado por todas as empresas que controla passou de cerca de 380 mil toneladas em 1999 para mais de um milhão em 2004. Observa-se que o principal crescimento ocorreu na Ferroban bitola larga. É relevante notar também a diminuição da importância do açúcar acondicionado (ensacado) no transporte ferroviário que, em 2004, praticamente já não existiu.

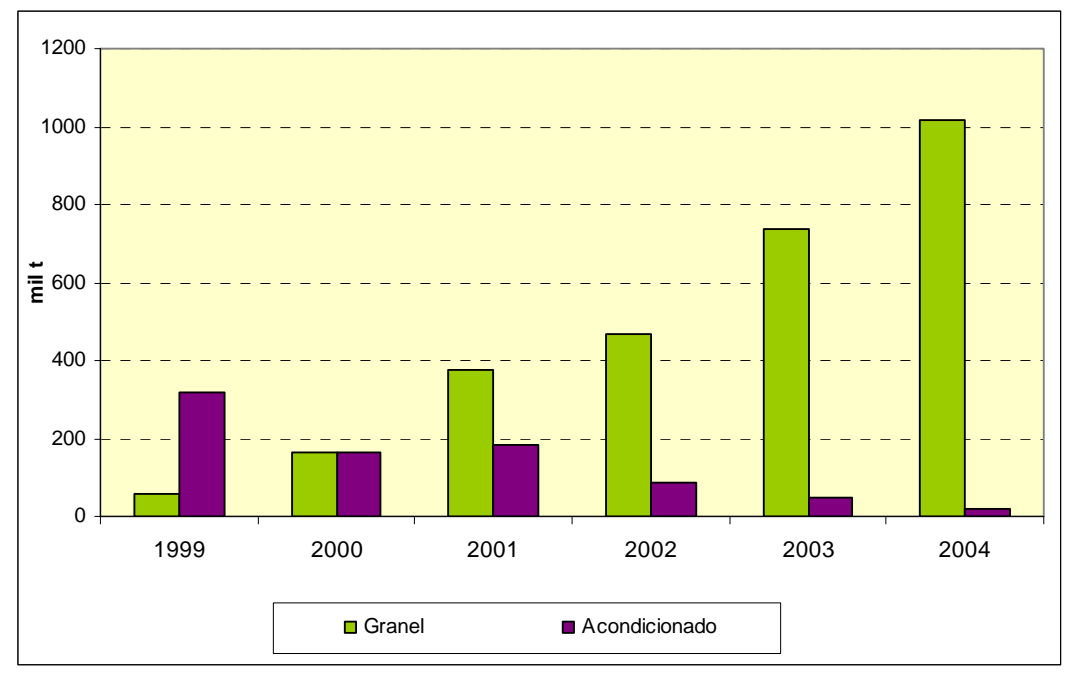

Figura 23 - Volume anual de açúcar operado pela Brasil Ferrovias

Fonte: Brasil Ferrovias (2005)

\footnotetext{
${ }^{15} \mathrm{O}$ aspecto regulatório do direito de passagem não foi definido adequadamente no momento da privatização implicando um gargalo logístico. Uma empresa acaba tendo que pagar à outra um valor desproporcional ao uso do trecho (já que esbarra em uma situação de monopólio). Atualmente, é exercido o regime de tráfego mútuo na região, o que provoca interrupção na viagem e altos custos.
} 
Tudo indica que este momento é bastante propício para o crescimento do transporte ferroviário. Alguns desafios ainda precisam ser superados como a realização dos investimentos da União e dos concessionários no modal, a obtenção de fontes adequadas de financiamento e equacionamento das questões regulatórias a fim de mitigar os riscos envolvidos no setor. O governo se prepara para investir no setor e os empresários usam a criatividade para driblar os não raros baixíssimos índices de eficiência deste modal e as condições adversas de investimento no setor a fim de viabilizar o aumento da participação desta modalidade na matriz de transporte e diminuir os gargalos logísticos brasileiros.

\subsubsection{O armazenamento de produtos agrícolas}

As funções da armazenagem, segundo Sasseroni (1995), estão classificadas em intrínsecas e extrínsecas. As funções intrínsecas da armazenagem são conservação da produção, redução de perdas e estocagem dos excedentes agrícolas. As funções extrínsecas, por sua vez, estão relacionadas com o transporte e a comercialização da produção agrícola, são elas: racionalizar o transporte (se não houvesse armazéns, toda a safra teria que ser escoada no momento da produção, o que demandaria uma quantidade de veículos muito grande); coleta de safra (para manter um fluxo regular de produto até a região de consumo); suporte de comercialização; formação de estoques reguladores; e auxílio às políticas governamentais.

Os armazéns são, portanto, bastante importantes no contexto agrícola, onde predominam culturas sazonais, pois permitem que os produtos alcancem preços razoáveis no período de safra e entressafra, garantem o abastecimento do mercado interno e do externo e racionalizam o transporte.

Sasseroni (1995) classifica a rede armazenadora brasileira segundo seu uso (público ou privado); segundo sua localização (em nível de produtor, coletoras, intermediárias e terminais); e segundo seu modo de armazenar (armazéns para sacaria, 
convencionais, estruturados, infláveis, unidades armazenadoras a granel, silos metálicos, silos verticais de concreto, horizontais de concreto, de madeira, de alvenaria, armazéns graneleiros e armazéns granelizados).

Beskow \& Deckers (2002) mostram a evolução da capacidade estática da armazenagem no Brasil (vide Tabela 7). Observa-se que em todo o período a maior concentração de armazéns se deu na região Sul e isto ainda persiste nos dias de hoje, conforme mostram os dados da CONAB contidos na Tabela 8.

Tabela 7. Evolução da capacidade estática de armazenagem no Brasil de 1978 a 2002

\begin{tabular}{|c|c|c|c|c|c|c|}
\hline \multirow{2}{*}{$\begin{array}{l}\text { Ano } \\
\text { UF }\end{array}$} & \multicolumn{2}{|c|}{1978} & \multicolumn{2}{|c|}{1992} & \multicolumn{2}{|c|}{2002} \\
\hline & $\mathrm{N}^{0}$ arm. & $\begin{array}{l}\text { Capacidade } \\
\text { (mil t) }\end{array}$ & $\mathrm{N}^{\circ}$ arm. & $\begin{array}{c}\text { Capacidade } \\
\text { (mil t) }\end{array}$ & $\mathrm{N}^{0}$ arm. & $\begin{array}{l}\text { Capacidade } \\
\text { (mil t) }\end{array}$ \\
\hline Sul & 6.297 & 27.517 & 4.574 & 28.364 & 7.168 & 39.349 \\
\hline Centro-Oeste & 864 & 3.036 & 2.394 & 20.266 & 2.717 & 28.592 \\
\hline Sudeste & 3.504 & 13.504 & 1.052 & 7.970 & 2.156 & 15.972 \\
\hline Nordeste & 1.338 & 2.582 & 790 & 3.117 & 974 & 4.143 \\
\hline Norte & 103 & 273 & 340 & 1.663 & 410 & 1.548 \\
\hline $\begin{array}{l}\text { TOTAL } \\
\text { BRASIL }\end{array}$ & 12.106 & 46.912 & 9.150 & 61.379 & 13.425 & 89.604 \\
\hline
\end{tabular}

Fonte: Beskow \& Deckers (2002)

O maior crescimento da rede armazenadora se verificou no Centro Oeste, passando de uma capacidade total da ordem de 3 milhões de toneladas no final da década de 80 para mais de 30 milhões em 2004. Pode-se perceber também o aumento da capacidade estática média dos armazéns, o número de armazéns cresceu 14\% e a capacidade aumentou mais de $100 \%$. A Tabela 8 mostra também que há um equilíbrio entre o número de armazéns convencionais e graneleiros, porém o segundo tipo tem uma capacidade total quase três vezes maior. 
Tabela 8. Quantidade e capacidade estática dos armazéns cadastrados na CONAB, por espécie e região, posição agosto / 2004

\begin{tabular}{lcccccc}
\hline \multicolumn{1}{c}{ Espécie } & \multicolumn{2}{c}{ Convencional } & \multicolumn{2}{c}{ Granel } & \multicolumn{2}{c}{ Total } \\
\multicolumn{1}{c}{ UF } & $N^{0}$ arm. & $\begin{array}{c}\text { Capacidade } \\
\text { (mil t) }\end{array}$ & $\mathrm{N}^{\circ}$ arm. & $\begin{array}{c}\text { Capacidade } \\
\text { (mil t) }\end{array}$ & $\mathrm{N}^{\circ}$ arm. & $\begin{array}{c}\text { Capacidade } \\
\text { (mil t) }\end{array}$ \\
\hline Sul & 3.097 & 8.201 & 4.274 & 34.855 & 7.371 & 43.057 \\
Centro-Oeste & 1.169 & 5.304 & 1.706 & 26.232 & 2.875 & 31.536 \\
Sudeste & 1.581 & 7.894 & 617 & 7.949 & 2.198 & 15.843 \\
Nordeste & 775 & 2.031 & 187 & 1.624 & 962 & 3.655 \\
Norte & 363 & 1.206 & 67 & 586 & 430 & 1.792 \\
TOTAL & 6.985 & 24.636 & 6.851 & 71.246 & 13.836 & 95.883 \\
BRASIL & & & & & & \\
\hline
\end{tabular}

Fonte: Companhia Nacional de Abastecimento (Conab) (2004)

As Figuras 24 e 25 mostram que cerca de 70\% dos armazéns no Brasil são privados, enquanto que $24 \%$ pertencem a cooperativas e $7 \%$ são públicos e que a maioria dos armazéns está na cidade (54\%), enquanto que 31\% estão na zona rural, $10 \%$ nas fazendas e 5\% são os terminais portuários.

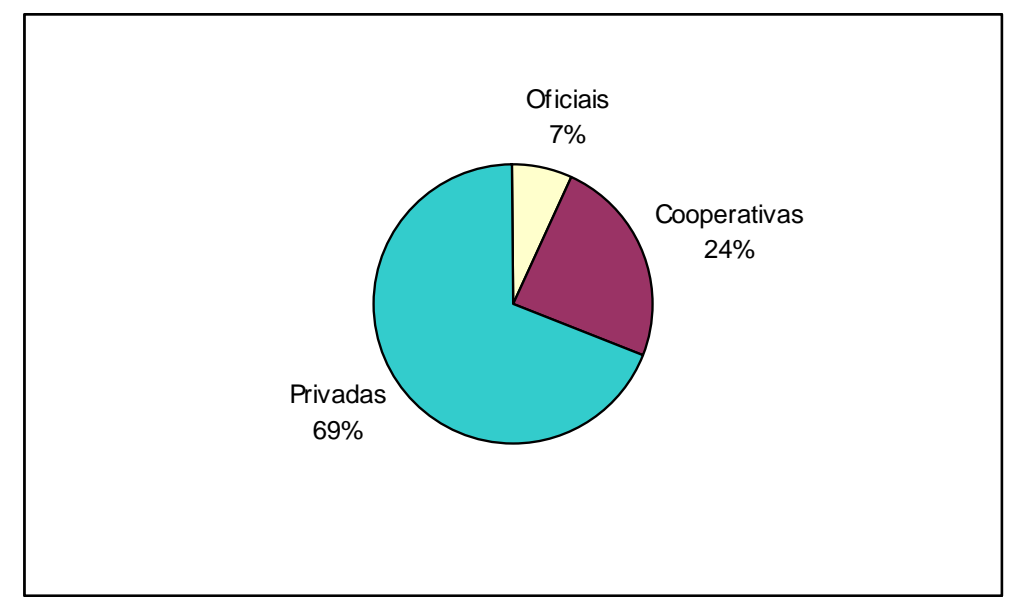

Figura 24 - Distribuição da capacidade estática por entidade Fonte: Conab (2004) 


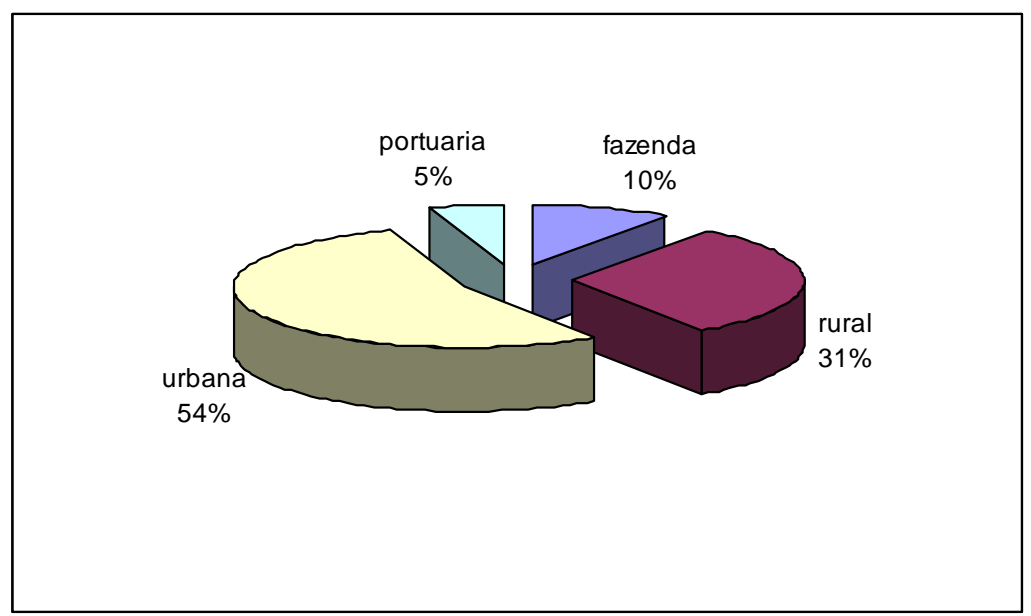

Figura 25 - Distribuição da capacidade por localização Fonte: Conab (2004)

No caso da estocagem do açúcar a granel, ela pode ser feita em silos, armazéns graneleiros ou granelizados (que são os armazéns convencionais adaptados para receber grãos). O açúcar pode ser armazenado em sacos ou a granel. Segundo a Cosan (2004), a utilização de sacos, predominante no passado, vem perdendo espaço. A armazenagem a granel traz uma série de vantagens econômicas, entre elas a de assegurar uma deterioração mais lenta do produto. Este é um dos motivos de este trabalho estar focado no açúcar a granel.

Um exemplo interessante de aproveitamento das vantagens da movimentação do açúcar a granel, a EDF\&Man adquiriu quatro navios BIBO (Bulk in Bags out), que possuem unidades de ensacamento dentro do próprio navio e sistema de descarga automatizado que permitiu a este trader reduzir seus custos.

O canal de comercialização do açúcar (vide Figura 26) envolve todos os agentes ligados a seu comércio, desde a produção até o consumidor final. O açúcar que sai das usinas pode ser comercializado pela própria usina e seguir para o atacado ou diretamente para o varejo ou ainda pode seguir para um armazém (que pode ser o 
próprio da usina, quando existir) para estocagem e posterior comercialização. Além disso, o açúcar pode também ser comercializado por traders (empresas especializadas em comércio internacional) que por sua vez podem contratar o transporte da usina diretamente para o porto ou fazer o produto passar por um armazém (a fim de realizar transbordo para outra modalidade de transporte ou armazenar o produto até o momento ideal da sua comercialização).

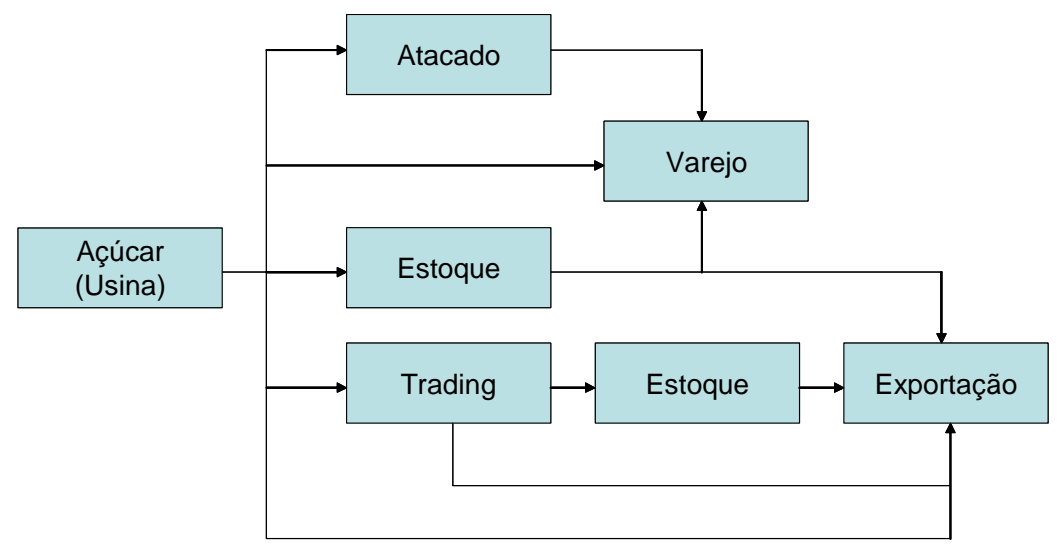

Figura 26 - Canais de comercialização

O açúcar necessita de alguns cuidados especiais durante sua armazenagem, apesar de não ser um produto com alta perecibilidade. $\mathrm{O}$ açúcar pode, por exemplo, empedrar e os fatores que o predispõe a isso, são aqueles que possibilitam a troca de umidade do cristal com a atmosfera envolvente, sendo que esses fatores podem ser próprios do açúcar (através das suas condições de umidade, temperatura, granulometria etc) ou dependente do armazém em que se encontra o produto ou ainda das condições atmosféricas (Procana, 2004). Uma estratégia que pode minimizar esse tipo de problema é o armazenamento desse produto durante 72 horas em silos de condicionamento dentro das usinas para que ocorra uma troca de temperatura com o ambiente.

A armazenagem do açúcar é bastante importante em termos de comercialização devido à sazonalidade do produto e à sua condição de commodity 
agrícola. O armazém é também fundamental para o transporte ferroviário devido à necessidade de concentração de carga para viabilizar o transporte eficiente do produto. Além disso, os terminais localizados no interior, próximos às áreas de produção, permitem controlar melhor a chegada de mercadorias nos portos e isso pode promover uma vantagem competitiva interessante para empresas que possuírem estes armazéns, dados a saturação atual dos portos e seus custos de armazenagem elevados.

Num contexto de escassez de ativos ferroviários e vias precárias, é importante ressaltar que altas capacidades de recepção e expedição dos armazéns, inclusive os portuários, se tornam essenciais, pois estas aumentam o ciclo dos vagões e, conseqüentemente, a oferta de transporte ferroviário.

O estado de São Paulo possui alguns armazéns localizados nas imediações das ferrovias que cortam o estado, dentre eles alguns terminais açucareiros especializados que foram construídos recentemente para atender a demanda de alguns grandes grupos comercializadores de açúcar.

No "Seminário Internacional em Logística Agroindustrial”, realizado em 19 de março de 2004 na ESALQ, participaram agentes do setor sucroalcooleiro que enfatizaram a importância da armazenagem tanto no porto como no interior do país. A Crystalsev, por exemplo, mencionou que a reserva de espaço em armazéns possibilita a otimização do uso dos terminais portuários, possibilita surgimento de oportunidades comerciais com terceiros e aumento da movimentação na entressafra que possibilita ganhos com fretes e eventuais ganhos comerciais via preço.

Dado este contexto em que a ferrovia vem se tornando mais competitiva, ganhando mais espaço e credibilidade, este trabalho pretende identificar o local mais adequado para instalação de novo terminal concentrador de carga, que possibilitará o transporte do açúcar para exportação utilizando a modalidade ferroviária. Para isso será desenvolvido um modelo matemático de otimização cujo objetivo é a minimização dos custos de transporte e armazenagem. 


\section{MATERIAL E MÉTODOS}

Para atingir o objetivo proposto neste trabalho, utilizar-se-á da Pesquisa Operacional que, a partir de métodos de programação matemática (linear e inteira), será o arcabouço teórico utilizado para referenciar a especificação do modelo matemático de localização ótima para armazéns concentradores de carga no estado de São Paulo.

\subsection{Modelagem matemática de otimização em problemas de localização industrial}

Johann Heinrich Von Thünen é considerado o precursor dos teóricos da localização. Focou o problema da localização na atividade agrícola, propondo um procedimento que passou a ser chamado "anéis de Von Thünen" (circunferências ao redor dos municípios que delimitam a área de cultivo de diferentes produtos agrícolas). Já Wilhem Launhardt direcionou seus estudos para a atividade industrial, enquanto Alfred Weber foi quem deu um impulso mais vigoroso na teoria, identificando as causas econômicas que determinavam a localização das indústrias (Banco do Nordeste, 1968).

O Manual elaborado pelo Banco do Nordeste (1968, p. IX) define o problema da localização como o da "condicionalidade espacial das atividades econômicas. $\mathrm{Ou}$, em outras palavras, das influências que o espaço geográfico exerce sobre aquelas atividades, uma vez que elas se acham, natural e necessariamente, condicionadas pela distribuição espacial dos recursos de produção, de um lado, e dos aglomerados humanos, do outro; o que implica, de um ponto de vista da Economia, em introduzir-se, ou no estudo teórico ou no tratamento empírico das mesmas, a variável 
distância". É importante considerar o aspecto espacial das atividades econômicas, pois influenciam os custos dos fatores de produção.

A localização de um empreendimento é, neste sentido, um problema de escolha da melhor combinação de vários fatores como capital, mão-de-obra, recursos naturais e insumos. Nos problemas de localização, há que se analisar as disponibilidades (recursos e mercados) de uma região e relacioná-las às características da atividade econômica em estudo (Banco do Nordeste, 1968). Porém, nos estudos de localização, os fatores locacionais são dinâmicos e podem mudar ao longo do tempo; além disso, há necessidade de se levar em consideração motivações de ordem subjetiva e políticas envolvidas neste processo de tomada de decisões.

Azzoni (1982, p.7) ressalta a importância do trabalho de Alfred Weber que, em 1909, "apresentou uma teoria geral e abstrata para a localização de uma firma individualmente. Analisa, separadamente, a influência de custos de transporte, do fator mão-de-obra e das forças aglomerativas", estas últimas tratam-se tanto de economias de escala como de outras economias como a de localização. Weber mostra que a localização ótima da firma se dá no ponto de menor custo de transporte, ponderado pelos custos com mão-de-obra e outros custos referentes a economias de aglomeração.

Alguns autores, citados por Azzoni (1982), criticam a ênfase dada aos custos de transporte na determinação da localização de firmas, afirmando que a participação destes no custo total do produto tem sido cada vez menor. Isso pode até ser verdade para casos de produtos com alto valor agregado, porém no caso de commodities agrícolas, este custo ainda tem grande relevância.

Ramos (2001) afirma que o surgimento da programação linear tornou possível a modelagem de problemas mais complexos que o weberiano, possibilitando a inclusão de várias regiões de demanda e de oferta.

Os modelos multi-regionais tentam resolver a questão da alocação de produtos a partir de várias regiões produtoras para várias regiões de consumo, limitados 
pela consideração de produção e consumo regionais fixos. Barros (2004) afirma que o modelo multi-regional parte das hipóteses de que o produto é homogêneo, produzido em quantidades predeterminadas em $m$ pontos produtores e consumidos em $n$ pontos consumidores, também em quantidades predeterminadas. Os pontos de produção e consumo são conectados por vias de transporte, a custos unitários pré-definidos. $\mathrm{O}$ objetivo do modelo é obter o padrão de comércio inter-regional que minimizará o custo de transferência. A limitação surgida ao considerar produção e consumo fixos faz com que as soluções ótimas obtidas sejam consideradas de curto prazo. As pressuposições e os dados do modelo devem ser testados para avaliar a estabilidade da solução obtida.

Os modelos de programação matemática podem ser classificados em três tipos: lineares, não-lineares e inteiros. Os modelos lineares pressupõem relações lineares entre as variáveis do problema e qualquer relação não-linear presente ou na função objetivo ou nas restrições caracteriza um modelo não-linear. A programação inteira é utilizada para problemas que exigem variáveis inteiras ou alguma relação lógica entre as variáveis, como é o caso de modelos que utilizam variáveis binárias (do tipo 0-1). Algoritmos diferentes são desenvolvidos para resolução de cada tipo de programação (e há diferentes algoritmos para resolução de programações do mesmo tipo), dado o nível de complexidade distinto de cada modelo.

Segundo Caixeta-Filho (2001), a programação linear propagou-se a partir de trabalhos publicados na área militar, em especial a partir do trabalho publicado por George B. Dantzig na década de 40. Sua pesquisa abordava o tema de distribuição ótima de tropas entre as diversas batalhas durante o período da Segunda Guerra Mundial. O Método Simplex, fruto deste esforço de pesquisa, é o algoritmo mais comentado e utilizado na literatura especializada e nos softwares de programação linear para resolução dos problemas.

Lopes (1997) ressalta a importância do avanço científico na área de modelagem para localização com a utilização da programação inteira-mista. O autor afirma que a teoria da localização pode ser entendida como uma variação do modelo de 
transporte que, em conjunto com a programação inteira, constitui um ferramental interessante para a determinação do local ótimo para instalação de uma firma. A possibilidade de incluir variáveis binárias no modelo tornou possível testar diversas capacidades de processamento para cada região. Os resultados deste tipo de modelo indicam não apenas a melhor localização, mas também a capacidade ótima de processamento para a região.

O modelo de programação matemática que será desenvolvido neste trabalho é do tipo inteiro-misto, pois, além da linearidade presente nas relações entre as variáveis, a variável binária 0 -1 será incorporada no modelo a fim de representar decisões do tipo "sim” ou "não", referindo-se à instalação ou não de um armazém em determinado local.

É de extrema importância deixar claro que os modelos deverão ser utilizados como instrumentos de auxílio à decisão e não devem ser vistos como verdades incontestáveis; além disso, a estrutura e a qualidade dos dados que os compõem é fundamental para o nível de qualidade dos resultados. Williams $(1993$, p.4) afirma "the quality of the answers which a model produces obviously depends on the accuracy of the structure and data of the model. [...] Uncritical faith in a model is obviously unwarranted and dangerous. Such an attitude results from a total misconception of how a model should be used as one of a number of tools for decision making”.

Algumas pressuposições acompanham os modelos de programação linear que, apesar de relativamente fortes, tornam sua resolução mais simples e possibilitam a garantia de resultado ótimo em um curto espaço de tempo. Caixeta-Filho (2001, p.11) cita-as: todas as relações entre as variáveis devem ser lineares o que "implica a proporcionalidade das contribuições envolvidas (por exemplo, a contribuição individual de cada variável é estritamente proporcional ao seu valor), assim como a aditividade dessas contribuições (por exemplo, a contribuição total de todas as variáveis é igual à soma das contribuições individuais, independentemente dos valores das variáveis)”.

Apesar de todas as limitações de um modelo de programação linear, seu uso pode ser bastante interessante tanto para iniciativa privada quanto para o poder público, 
como um instrumento capaz de orientar as decisões e, o que pode ser ainda mais importante, a formulação de modelos, geralmente, conduz a um conhecimento profundo do problema.

O modelo matemático proposto está baseado em um modelo de transporte que, genericamente, é descrito a seguir.

Sendo $m$ o número total de regiões ou unidades produtoras e $n$ o número total de destinos para o produto, a função objetivo a ser minimizada (1) refere-se ao custo total de transporte $C$ :

$$
\operatorname{Min} C=\sum_{i=1}^{m} \sum_{j=1}^{n} C_{i j} X_{i j}
$$

onde:

$C_{i j}=$ custo para transportar uma unidade do produto da origem $i$ para o destino $j$;

$X_{i j}=$ quantidade a ser transportada da origem $i$ ao destino $j$.

As quantidades transportadas devem respeitar as restrições de disponibilidade de produto na origem, de demanda no destino e o balanceamento entre oferta e demanda, além da não-negatividade das variáveis quantidades, já implícita na forma de resolução por parte da maioria dos algoritmos de programação linear.

$\checkmark$ A soma das quantidades transportadas $\left(X_{i j}\right)$ não deve exceder a capacidade de oferta das unidades produtoras:

$$
\sum_{j=1}^{n} X_{i j} \leq S_{i}, \text { para todo } i
$$

onde:

$S_{i}=$ oferta de produto na região $i$. 
$\checkmark$ A soma das quantidades transportadas $\left(X_{i j}\right)$ para o destino $j$ não pode ser menor que a demanda desta região:

$$
\sum_{i=1}^{m} X_{i j} \geq D_{j}, \text { para todo } j
$$

onde:

$D_{j}=$ demanda do produto na região $j$.

$\checkmark$ Deve haver um balanceamento entre oferta e demanda (caso não haja, é necessário inserir uma origem ou destino fictício):

$$
\sum_{j=1}^{n} D_{j}=\sum_{i=1}^{m} S_{i}
$$

onde:

$$
\begin{aligned}
& \sum_{j=1}^{n} D_{j}=\text { demanda total pelo produto; } \\
& \sum_{i=1}^{m} S_{i}=\text { oferta total do produto. }
\end{aligned}
$$

$\checkmark$ Obviamente, as quantidades transportadas $\left(X_{i j}\right)$ não podem ser negativas:

$$
X_{i j} \geq 0
$$

A restrição (4), conforme afirmam Amaro \& Silva (1973), elimina o valor das desigualdades de (2) e (3). Os autores ressaltam as limitações deste tipo de modelo. Admite-se que:

a) há concorrência perfeita;

b) não há economias de escala no transporte;

c) não há custos de transporte até o mercado de aglomeração, nos casos de produções espacialmente dispersas;

d) tecnologia é constante;

e) ofertas e demandas são conhecidas; 
f) as variáveis estão linearmente inter-relacionadas;

g) não há economias de escala no processamento.

No modelo específico desenvolvido neste trabalho, destacam-se as limitações (b), (d), (e), (f) e (g). Na prática, a limitação (b) indica que o frete independe da quantidade transportada, ou seja, é o mesmo para cada unidade adicional de produto; (d) considera a existência de um padrão tecnológico constante de transporte e armazenagem; (e) refere-se à limitação de que ofertas e demandas de açúcar são previamente conhecidas; já (f) adverte que há uma relação linear entre as variáveis, ou seja, há uma proporcionalidade das contribuições envolvidas (cada variável contribui proporcionalmente ao seu valor) e uma aditividade dessas contribuições (não existe interação entre as variáveis); finalmente, a limitação (g) trata da independência do custo unitário de armazenagem para com o volume de produto armazenado.

A especificação dos dados e os passos para o desenvolvimento do modelo proposto, assim como suas representações matemática e diagramática, são assunto dos próximos tópicos.

\subsection{Modelo proposto}

O objetivo do modelo desenvolvido neste trabalho é encontrar a localização ótima para a construção de armazém intermodal de açúcar a granel no estado de São Paulo, de tal forma que os custos de transporte do açúcar e do seu armazenamento sejam minimizados. Além disso, o modelo buscará determinar a capacidade mais adequada para o armazém, respeitando a oferta das regiões produtoras e a demanda de açúcar pelo porto.

A idéia geral é modelar matematicamente o fluxo de açúcar que sai das usinas do estado de São Paulo com destino à exportação. Este açúcar pode percorrer o 
trajeto da usina ao porto por caminhão ou pode seguir, também por via rodoviária, para uma unidade armazenadora com a finalidade de realização de um transbordo para outra modalidade de transporte (no caso, a ferroviária) ou para armazenagem do produto até o momento mais interessante para sua comercialização. O objetivo do modelo, então, será o de determinar os locais mais adequados para instalação destes armazéns, suas capacidades ótimas e os fluxos do produto que levam a um custo logístico mínimo. Espera-se, portanto, obter a minimização dos custos de transporte e de armazenagem, dadas as restrições impostas ao modelo.

\subsubsection{Representação diagramática}

A Figura 27 apresenta o diagrama esquemático do modelo proposto no qual são representadas $m$ usinas $\left(\mathrm{U}_{\mathrm{i}}\right), p$ armazéns de tamanho $t$ (serão considerados $q$ tamanhos) $\left(\mathrm{A}_{\mathrm{j} t}\right)$ e $n$ portos $\left(\mathrm{P}_{\mathrm{k}}\right)$. O diagrama mostra as possibilidades do açúcar das usinas chegarem aos portos. No modelo cada usina tem basicamente duas alternativas, quais sejam: transporte rodoviário direto para o porto $\left(\mathrm{Z}_{\mathrm{ij}}\right)$ ou transporte rodoviário para o armazém $\left(\mathrm{X}_{\mathrm{ij}}\right)$ seguido de transporte ferroviário para o porto $\left(\mathrm{Y}_{\mathrm{jk}}\right)$. A alternativa hidroviária não foi levada em consideração por ser ainda muito incipiente para o setor açucareiro. 


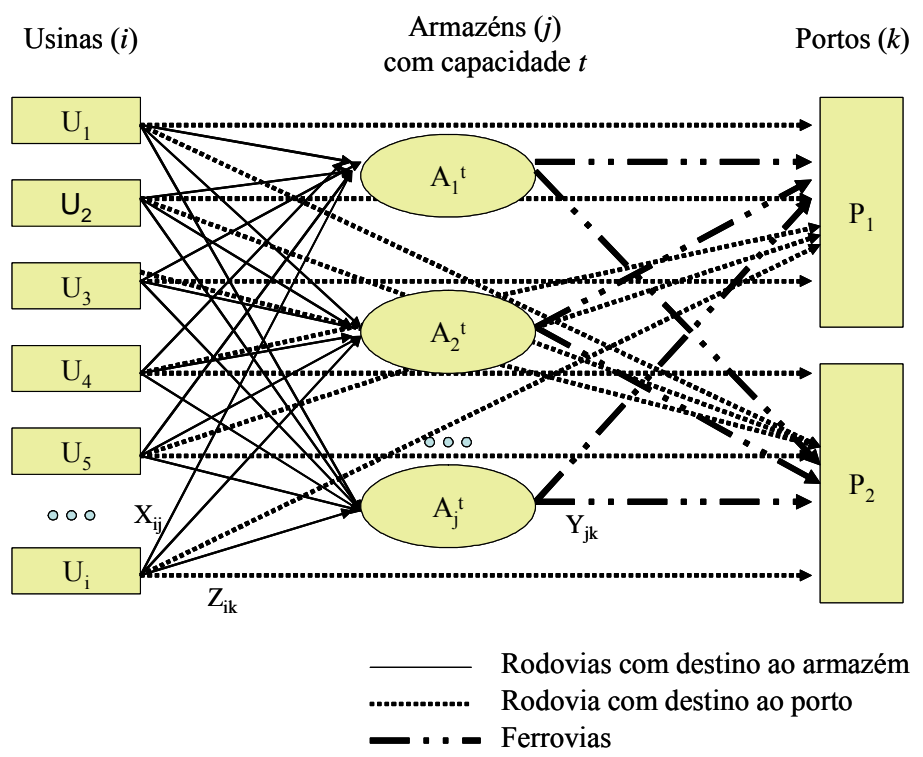

Figura 27 - Representação diagramática do modelo de localização ótima

\subsubsection{Representação matemática}

O modelo que será apresentado neste tópico refere-se à minimização de uma função objetivo $(C)$ que representa de forma simplificada os custos obtidos na exportação de açúcar do estado de São Paulo. O objetivo da minimização é encontrar a localização ótima de armazéns intermodais concentradores de carga no interior do estado de São Paulo que impliquem o menor custo total possível para movimentação da carga. O objetivo é, portanto, encontrar as quantidades que tornam (6) o menor possível, mas que satisfaça (7), (8), (9), (10), (11) e (12).

1) Função objetivo

$$
\operatorname{Min} \sum_{i=1}^{m} \sum_{j=1}^{p} c_{i j} x_{i j}+\sum_{j=1}^{p} \sum_{k=1}^{n} d_{j k} y_{j k}+\sum_{i=1}^{m} \sum_{k=1}^{n} e_{i k} z_{i k}+\sum_{j=1}^{p} H_{j}+\sum_{k=1}^{n} C P_{k} w_{k}
$$

onde:

$C_{i j}=$ custo de transporte rodoviário por tonelada entre a usina $i$ e armazém $j$;

$x_{i j}=$ quantidade (em mil toneladas) transportada da usina $i$ ao armazém $j$, via rodovia; 
$d_{j k}=$ custo de transporte ferroviário por tonelada entre o armazém $j$ e o porto $k$;

$y_{j \mathrm{k}}=$ quantidade (em mil toneladas) transportada do armazém $j$ para o porto $k$;

$e_{i k}=$ custo de transporte rodoviário por tonelada da usina $i$ para o porto $k$;

$z_{i \mathrm{k}}=$ quantidade (em mil toneladas) transportada diretamente da usina $i$ ao porto $k$, via rodovia;

$H_{j}=$ custo operacional do armazém de tamanho $t$ em $j$;

$C P_{k}=$ custo portuário por tonelada;

$w_{k}=$ quantidade de produto que chega no porto (em mil toneladas).

Desmembrado a função objetivo, obtêm-se as seguintes parcelas:

$$
\begin{aligned}
& \sum_{i=1}^{m} \sum_{j=1}^{p} c_{i j} x_{i j} \\
& \sum_{j=1}^{p} \sum_{k=1}^{n} d_{j k} y_{j k} \\
& \sum_{i=1}^{m} \sum_{k=1}^{n} e_{i k} z_{i k} \\
& \sum_{j=1}^{p} H_{j} \\
& \sum_{k=1}^{n} C P_{k} w_{k}
\end{aligned}
$$

A expressão (6a) denota o custo de transporte de açúcar entre a usina $i$ e o armazém $j$, este trecho entre a unidade produtora e o armazém é conhecido com ponta ou pernada rodoviária. A parcela $(6 b)$ representa o custo de transporte ferroviário entre o armazém $j$ e o porto $k$ enquanto que a (6c) retrata o custo de transporte rodoviário direto 
entre a usina $i$ e o porto $k$. As expressões (6d) e (6e) representam, respectivamente, o custo operacional de armazenagem e custo portuário gerado pela movimentação do açúcar nestes locais.

2) Restrições:

a) Capacidade de produção das usinas: a quantidade de açúcar transportado da usina $i$ ao armazém $j$ somada à quantidade transportada da usina $i$ diretamente para o porto $k$ não deve exceder a produção desta usina:

$$
\sum_{j=1}^{p} x_{i j}+\sum_{k=1}^{n} z_{i k} \leq S_{i}, \text { para todo } i
$$

onde:

$S_{i}=$ produção da usina $i$.

b) Capacidade dos armazéns: a quantidade de açúcar que chega no armazém $j$ não deve exceder sua capacidade dinâmica.

$$
\sum_{i=1}^{m} x_{i j} \leq \sum_{t=1}^{q} C A P_{t} B_{j t}, \text { para todo } j
$$

onde:

$C A P_{t}=$ capacidade dinâmica do armazém de tamanho $t$ localizado em $j$;

$B_{j t}=$ variável binária (do tipo 0-1) associada à instalação ou não de um armazém de tamanho $t$ localizado em $j$.

c) Quantidade de açúcar que entra nos armazéns é igual à quantidade que sai dos armazéns: 


$$
\sum_{i=1}^{m} x_{i j}=\sum_{k=1}^{n} y_{j k}, \text { para todo } j
$$

d) Volume de açúcar que sai da usina $i$ com destino ao porto $k$ somado ao volume que sai do armazém $j$ para o porto $k$ é igual ao volume total recebido pelo porto $k$ :

$$
\sum_{j=1}^{p} y_{j k}+\sum_{i=1}^{m} z_{i k}=w_{k}, \text { para todo } k
$$

onde:

$w_{k}=$ volume de produto que chega ao porto;

e) A demanda do porto deve ser atendida:

$$
\sum_{j=1}^{p} y_{j k}+\sum_{i=1}^{m} z_{i k} \geq \operatorname{EXPORT}_{k}, \text { para todo } k
$$

onde:

$\operatorname{EXPORT}_{k}=$ demanda do porto $k$ (exportação).

f) Número máximo de armazéns que podem ser instalados em cada região:

$$
\sum_{t=1}^{q} B_{j t} \leq a, \text { para todo } j
$$

onde:

$a=1$ para cenários $1,3^{16}$ e 4 ;

$a=2$ para cenário 2 e $3^{\prime}$;

${ }^{16}$ Para o cenário 3 foram testados $\mathrm{a}=1$ e $\mathrm{a}=2$. O cenário 3 que considera a $=2$ foi chamado de 3 '. 
g) Custo total de operação dos armazéns de tamanho $t$ a serem instalados em $j$ :

$$
H_{j}=\sum_{t=1}^{q} C O_{t} B_{j t}, \text { para todo } j
$$

A restrição (13) contabiliza o custo incorrido pela operação do armazém. Essa expressão representa uma simplificação importante do modelo: não importa a quantidade de produto que vai passar pelo armazém; qualquer que seja o volume, o custo incorrido pela sua utilização será o mesmo. A utilização do armazém gera um custo operacional pelo seu tamanho, independente da quantidade que passa por ele. Não será feito o custo por tonelada pelas dificuldades de incorporar este tipo de informação em modelos lineares. Não se levam em consideração, portanto, economias de escala.

A estrutura matemática apresentada (expressões 6 a 12) foi codificada e processada através da linguagem de otimização GAMS e pode ser consultada no Apêndice 1. Os dados utilizados para alimentar o modelo, bem como os cenários adotados, estão especificados nos próximos tópicos. O capítulo 4 apresenta os resultados obtidos e uma discussão sobre eles.

\subsubsection{Cenários}

Serão analisados quatro cenários $^{17}$ que serão diferenciados entre si pelas restrições ao número de terminais que podem ser instalados por região (restrição (f)), pelo custo operacional de armazéns instalados e pelo valor do frete ferroviário. A Tabela 9 sintetiza as diferenças entre os cenários. Estas variações foram adotadas para tentar perceber o impacto das alterações no resultado do problema.

\footnotetext{
${ }^{17}$ Para o cenário 3, foi brevemente analisada a mudança parâmetro $a$ do modelo.
} 
Tabela 9. Diferenciação entre os cenários

\begin{tabular}{cccc}
\hline Cenário & $\begin{array}{c}\text { Número de armazéns } \\
\text { por região }\left(\mathrm{B}_{\mathrm{ij}}\right)\end{array}$ & $\begin{array}{c}\text { Custo unitário de } \\
\text { armazenagem }\end{array}$ & $\begin{array}{c}\text { Frete ferroviário } \\
(\text { Base }=100)\end{array}$ \\
\hline 1 & $\mathrm{~B}_{\mathrm{ij}} \leq 1$ & $\mathrm{R} \$ 7,00 / \mathrm{t}$ & 100 \\
2 & $\mathrm{~B}_{\mathrm{ij}} \leq 2$ & $\mathrm{R} \$ 7,00 / \mathrm{t}$ & 100 \\
3 & $\mathrm{~B}_{\mathrm{ij}} \leq 1$ & 0 & 100 \\
3, & $\mathrm{~B}_{\mathrm{ij}} \leq 2$ & 0 & 100 \\
4 & $\mathrm{~B}_{\mathrm{ij}} \leq 1$ & $\mathrm{R} \$ 7,00 / \mathrm{t}$ & 110 \\
\hline
\end{tabular}

Fonte: dados da pesquisa

A diferença entre os cenários 1 e 2 é apenas o número de armazéns permitidos por região: no primeiro, a restrição (f) admite a instalação de apenas 1 e no segundo, 2. No terceiro cenário, foram desconsiderados os custos de armazenagem e observou-se o resultado para $B_{i j} \leq 1$ e para $B_{i j} \leq 2$ (cenário 3'). Esse cenário foi desenhado com o intuito de mostrar que, caso o resultado ótimo do modelo não inclua a instalação de armazém em alguma das potenciais localidades, o risco de investimento neste local poderia ser considerado alto, pois mesmo sem nenhum custo para o produto dentro do armazém, o fluxo ótimo não acusa a utilização deste, ou seja, mesmo excluindo custos de armazenagem, a alternativa intermodal não é competitiva. Já o cenário 4 foi considerado a fim de verificar os possíveis efeitos de um aumento relativo no frete ferroviário.

Todos eles considerarão a oferta de $60 \%$ da produção de 103 usinas do estado de São Paulo, dada a suposição de que $40 \%$ destina-se ao mercado interno. Serão considerados 11 possíveis locais para instalação dos armazéns concentradores de carga nas margens da ferrovia que poderão ser de 10 tamanhos distintos. $\mathrm{O}$ açúcar ofertado poderá ser destinado ao Porto de Santos ou de Paranaguá que demandarão, respectivamente, $90 \%$ e $8 \%$ da produção paulista destinada à exportação. Estas suposições serão detalhadas e justificadas na seção seguinte. 
Os custos de transporte e portuários foram estimados com base em informações do SIFRECA e de agentes do mercado. Foram estimados os custos de transporte de ponta rodoviária (percurso da usina ao armazém), ferroviário e rodoviário direto para o porto das alternativas cabíveis para cada uma das 103 usinas, além do custo incorrido pela movimentação do produto no porto.

Para estimativa dos custos de transporte, cada usina foi analisada individualmente e foram consideradas alternativas logísticas visualmente mais lógicas para cada uma delas, utilizando-se, além da hipótese de não consideração de ponta rodoviária grande (que inviabilizaria o transporte intermodal), a idéia de que dificilmente o produto sai das usinas e segue para locais distantes em direção oposta ao porto para realização de transbordo ou armazenagem.

Por exemplo, o açúcar de uma usina no extremo oeste do estado até poderia utilizar um armazém distante (distância maior que 200 quilômetros, por exemplo) que estivesse a leste do estado (em direção ao Porto de Santos), pois esta seria uma distância que indubitavelmente teria que ser percorrida pela carga para alcançar o porto. Entretanto, o açúcar de uma usina da região de Ribeirão Preto, por exemplo, dificilmente seguiria para um armazém a mais de 100 quilômetros em direção oeste do estado para depois ser transferida para o porto, a leste, pois isto significaria um aumento significativo na distância percorrida pela carga. Todas as alternativas que envolvem o transporte rodoviário direto da usina para os dois portos foram levadas em consideração. Para as alternativas não consideradas foi adotado um custo de transporte alto (R\$ 1000,00 / tonelada) de tal forma que se inviabilizasse o transporte do produto nesta rota.

Todos os cenários não consideram a existência prévia de armazéns no estado de São Paulo e também não forçam o estabelecimento de nenhum. Alterar-se-ão, nos diferentes cenários, os custos operacionais de armazenagem, o número permitido de armazéns por região e os fretes ferroviários. 


\subsubsection{Especificação dos dados}

Os dados necessários para formulação do modelo são: 1) os possíveis locais de demanda por armazéns concentradores de carga (os quais deverão estar na margem da via ferroviária); 2) as distâncias rodoviárias entre as usinas e os locais candidatos para instalação de armazéns, entre as usinas e os portos, além da distância ferroviária dos armazéns aos portos e os custos de transporte (rodoviário e ferroviário) por unidade de distância; 3) as capacidades de produção de açúcar das usinas; 4) as opções de tamanhos dos armazéns, ou seja, as possibilidades de capacidades operacionais que serão consideradas; e 5) os custos operacionais e de estocagem dos armazéns.

\subsubsection{Localizações potenciais}

Como possíveis locais para instalação de terminais intermodais no interior do estado de São Paulo foram escolhidos os seguintes municípios: Araçatuba, Araraquara, Barretos, Bauru, Boituva, Fernandópolis, Palmital, Pradópolis, Ribeirão Preto, Santa Adélia e Tupã. Esses municípios foram escolhidos porque representam praticamente todas as regiões do estado de São Paulo ${ }^{18}$, exceto o litoral norte e o extremo sudoeste que não são representativos em termos de produção para o mercado sucroalcooleiro. Eles servirão de referência para implantação ou não dos armazéns, não significando, contudo, que as plantas sejam necessariamente instaladas nestes municípios considerados, mas a indicação da região para instalação já é considerada satisfatória para este trabalho.

O mapa do Anexo A mostra os principais pontos de embarque da Brasil Ferrovias. Praticamente todos estes pontos que envolvem a movimentação de açúcar por esta empresa (quais sejam: Fernandópolis, São José do Rio Preto, Pitangueiras

\footnotetext{
${ }^{18}$ Contatos com agentes do setor sucroalcooleiro e ferroviário indicaram que a construção de armazéns nestas localidades pode ser interessante e, possivelmente, viável.
} 
(Passagem), Pradópolis, Jaú, Tupã e Araçatuba) estão contemplados nas áreas de influência dos municípios escolhidos para este trabalho.

Araçatuba representa a área de fronteira agrícola paulista da cana-de-açúcar. É a região onde a cultura da cana mais cresce no estado. Araraquara está numa região tradicional de cultivo da cana. Barretos entrou neste trabalho representando o norte do estado; já o município de Bauru, no entroncamento entre Novoeste e Ferroban, representa o centro-sul do estado. Boituva está a menos de $200 \mathrm{~km}$ do Porto de Santos e foi selecionada para representar a área próxima ao porto. Não raramente, ouve-se sobre a inviabilidade da utilização do transporte ferroviário a distâncias curtas em relação aos portos. Os resultados do modelo poderão dar alguma indicação sobre a validação de tal premissa.

Fernandópolis retrata as condições do noroeste do estado. Talvez a análise desta localidade seja prejudicada por este trabalho estar focado no estado de São Paulo e muito do açúcar operado neste local vem do Triângulo Mineiro ${ }^{19}$. Palmital foi considerado por estar sobre a Ferrovia ALL e possibilitar o transporte ferroviário para o porto de Paranaguá. Já Pradópolis entrou como possível localidade por ser sede da Usina São Martinho, a única no estado que possui desvio ferroviário ativo dentro da usina, permitindo ao seu armazém interno a possibilidade de embarque ferroviário direto da usina ao Porto de Santos.

Ribeirão Preto é a cidade mais importante do pólo sucroalcooleiro mais tradicional do país e por isso também será considerado no trabalho. Santa Adélia representará o centro-norte do estado e Tupã, o sudoeste do estado. A via ferroviária do estado passa por todos estes locais considerados, sob concessão da FCA (Ribeirão Preto), Brasil Ferrovias (Araçatuba, Araraquara, Barretos, Bauru, Boituva, Fernandópolis, Pradópolis, Santa Adélia e Tupã) e ALL (Palmital).

\footnotetext{
${ }^{19}$ Atualmente, a usina Coruripe opera um terminal especializado em Fernandópolis movimentando, neste local, açúcar proveniente de Iturama / MG.
} 
As usinas consideradas neste trabalho estão localizadas na área de influência destas localidades, consideradas a partir de uma circunferência com centro no município e um raio de 100 quilômetros. Essa amostra cobre cerca de $80 \%$ da produção do estado de São Paulo. A Figura 28 mostra o mapa com as usinas e as áreas de influência consideradas $^{20}$.

A análise dos resultados do modelo poderá fornecer informações da localidade e capacidade ótima (sujeitas às limitações do modelo) para armazéns e poderá dar indicações tanto de políticas públicas, como, por exemplo, para dimensionamento e foco dos Ceagesp ou para a construção de novos armazéns ou até mesmo para avaliar futuras possíveis parcerias com o setor privado via PPPs, como também indicações de oportunidades de negócio para o setor privado.

\footnotetext{
${ }^{20}$ Mapa georeferenciado (base de dados: vide referência nesta nota). As usinas do mapa foram plotadas no centróide do município considerado e as distâncias coletadas são de centro a centro. Em alguns casos, a comparação da distância entre usinas próximas entre si em relação a um determinado local pode ficar prejudicada. Por exemplo, Avanhadava (município onde se localiza a Usina Diana) está a $501 \mathrm{~km}$ de Santos enquanto que Promissão (onde se localiza a Usina Equipav) está a $516 \mathrm{~km}$. Apesar disso, no mapa a primeira parece estar mais distante de Santos que a segunda.

INSTITUTO BRASILEIRO DE GEOGRAFIA E ESTATÍSTICA (IBGE). Servidor de mapas. http://www.ibge.gov.br (15 jan. 2005)
} 


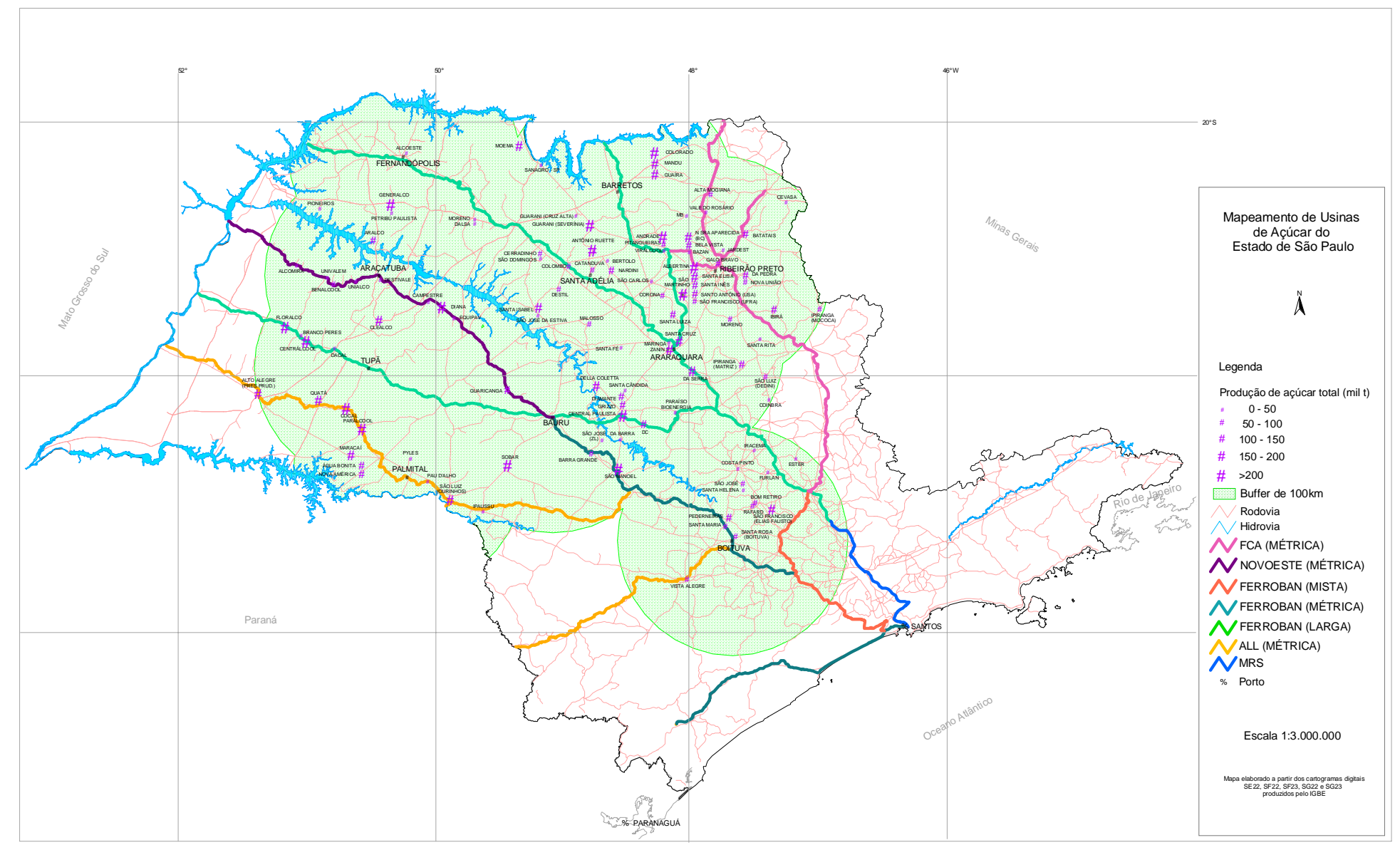

Figura 28 - Áreas de influência dos municípios considerados como possíveis locais para instalação de armazéns 


\subsubsection{Custos de transporte}

O CD-ROM Guia Quatro Rodas Rodoviário 2004 foi o instrumento utilizado para encontrar as distâncias rodoviárias ${ }^{21}$ enquanto que as ferroviárias foram obtidas junto à Brasil Ferrovias. A matriz de distâncias e custos está apresentada no Anexo B.

Para obtenção dos custos de transporte rodoviário e ferroviário com destino aos portos foram utilizados dados do Sistema de Informações de Fretes Agrícolas $(\text { SIFRECA) })^{22}$ e para os custos de transporte das pontas rodoviárias utilizou-se informações obtidas junto a agentes do setor $^{23}$, cujas identidades serão preservadas para não comprometer suas estratégias de negociação. Os dados de custo de transporte serão utilizados como coeficientes das quantidades movimentadas na função objetivo. Os dados originais obtidos encontram-se no Apêndice 2.

Para obtenção de estimativa dos custos de transporte entre as usinas e os armazéns (ponta rodoviária) foram utilizados dados de junho de 2004 obtidos junto a empresas do setor ${ }^{24}$. Para estimativa dos fretes de exportação (com destino aos portos de Santos e Paranaguá), foram analisados fretes praticados entre janeiro de 2002 e junho de 2004 constantes na base de dados do SIFRECA. Para estimativa do custo de rotas com origem nas usinas e destino ao Porto de Santos foram utilizados dados cujas rotas tinham origem no estado de São Paulo e destino aos Portos de Santos e Guarujá. Para custos de rotas com destino ao Porto de Paranaguá, foram usados os dados cujas rotas tinham origem no estado de São Paulo e destino ao Porto de Paranaguá. Os fretes ferroviários também foram obtidos através do SIFRECA e a análise dos dados se procedeu da mesma forma que para os fretes rodoviários.

\footnotetext{
${ }^{21}$ Quando a usina encontra-se no mesmo município do armazém, considerou-se a distância igual a $10 \mathrm{~km}$.

${ }^{22}$ SIFRECA, Piracicaba. Comunicação pessoal, 2004.

${ }^{23}$ Obtido por comunicação pessoal, 2004.

${ }^{24}$ Foram utilizados dados atuais obtidos junto a agentes do setor porque a série histórica deste tipo de frete não consta na base de dados do SIFRECA.
} 
As rotas foram separadas por faixas de distância de 100 quilômetros cada. Os valores nominais dos fretes da série histórica foram levados a valor presente de junho de 2004 e, a partir destes dados, foi feita uma média anual do frete unitário ( $\$$ /t.km) para cada intervalo de distância. Estes fretes unitários $(\mathrm{R} \$ / \mathrm{t} . \mathrm{km})$ foram multiplicados pelas distâncias $(\mathrm{km})$ entre as origens e os portos e encontrou-se o frete médio $(\mathrm{R} \$ / \mathrm{t})$ anual.

Os dados da série foram deflacionados para valores de junho de 2004 por um índice composto por $70 \%$ da variação do IGP-M e $30 \%$ da variação do diesel ${ }^{25}$ a fim de se tentar estimar o aumento dos custos (e supondo conseqüente alteração dos preços) para os transportadores de janeiro de 2002 a junho de 2004. A série histórica do IGP-M foi obtida no Instituto de Pesquisa Econômica Aplicada (IPEA) (http://www.ipeadata.gov.br) e os preços do diesel (média ponderada semanal praticados pelos produtores) foram obtidos em julho de 2004 na Agência Nacional do Petróleo (ANP) (http://www.anp.gov.br) e podem ser vistos no Apêndice 3. A Figura 29 mostra a evolução deste índice composto com base 100 em janeiro de 2002. Observa-se que o índice chega a aproximadamente 160 em junho de 2004.

\footnotetext{
${ }^{25}$ Essa composição de índices foi utilizada, pois algumas planilhas de custo disponíveis no mercado indicam que cerca de $30 \%$ do custo do transporte rodoviário refere-se a combustível e $70 \%$ a custos com manutenção e depreciação.
} 


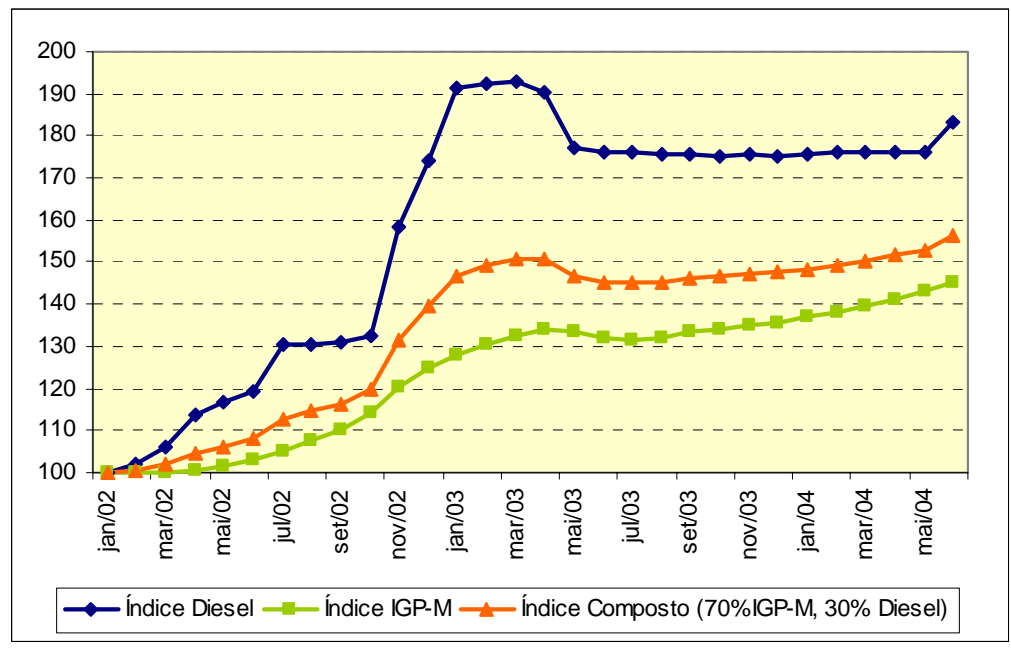

Figura 29 - Índices de preço (Base: Janeiro $2002=100$ )

Fonte: elaborado a partir de dados da ANP e do IPEA

Para estimar os custos das pontas rodoviárias entre as usinas e os armazéns foram utilizados os fretes praticados e cotados fornecidos por agentes do mercado para valores correntes de junho de 2004.

A matriz de custos calculada considera níveis de fretes médios anuais; porém, na prática, observa-se uma sazonalidade dos fretes rodoviários que varia principalmente com a demanda por transporte. Esta simplificação foi adotada a fim de facilitar a modelagem matemática do problema ${ }^{26}$.

As Figuras 30 e 31 mostram a sazonalidade média dos fretes rodoviários de açúcar cujas rotas têm origem e destino no estado de São Paulo.No período de pico de safra do açúcar, por exemplo, os fretes rodoviários para este produto no estado de São Paulo chegam a ser até $25 \%$ maiores que a média.

\footnotetext{
${ }^{26}$ Caso se considerasse a sazonalidade e, conseqüentemente, a variável tempo, possivelmente se observaria uma maior competitividade do transporte rodoviário direto ao porto no período de entressafra. Isso poderia diminuir a utilização do armazém neste período, porém, o período de entressafra é atualmente pouco maior que 4 meses, comparativamente aos quase 8 meses de operação. Portanto, esta premissa não tem grandes impactos na alocação ótima dos armazéns.
} 


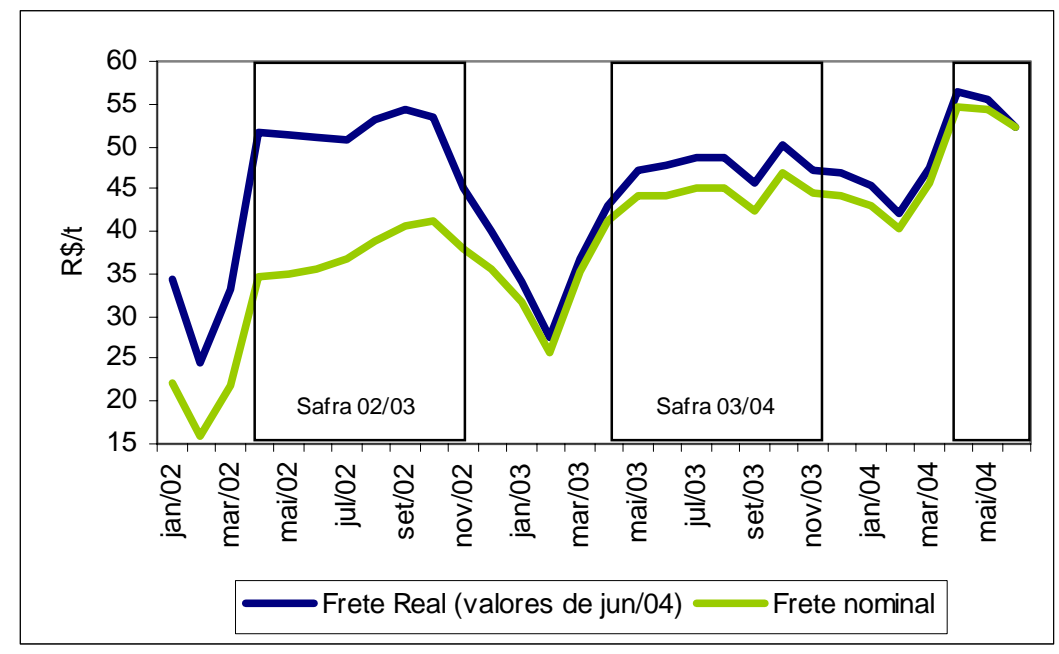

Figura 30 - Sazonalidade do frete rodoviário de açúcar a granel com origem no estado de São Paulo e destino a Santos, 2002 a 2004

Fonte: elaborado a partir de dados do SIFRECA

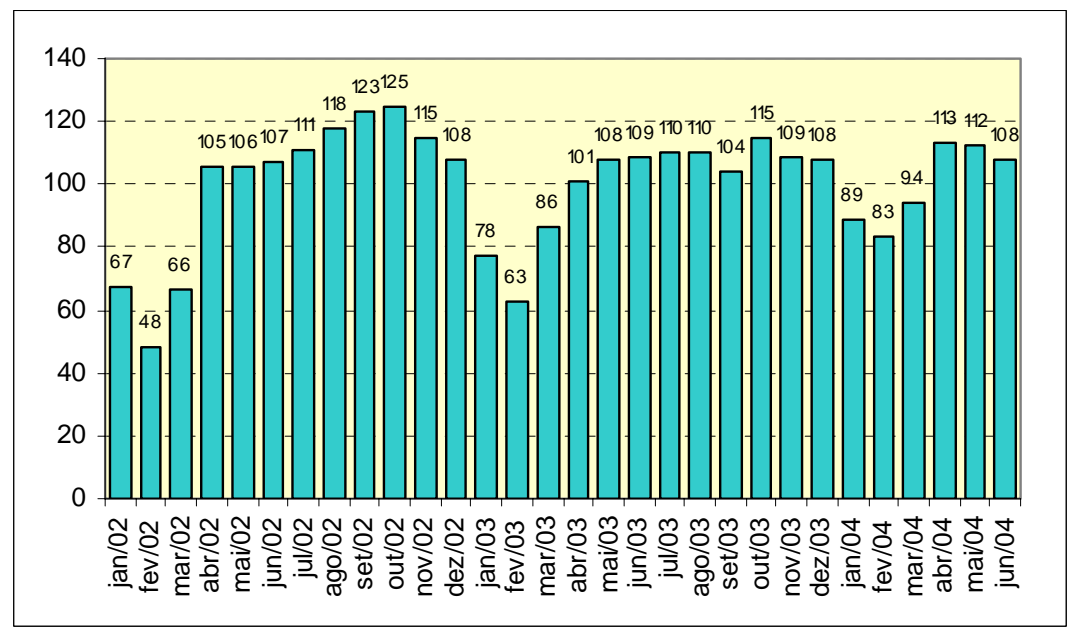

Figura 31 - Variação sazonal do frete rodoviário de açúcar a granel com origem no estado de São Paulo e destino a Santos, 2002 a 2004, medida em relação ao frete médio

Fonte: elaborado a partir de dados do SIFRECA 
A Figura 32 mostra a evolução mensal do frete de açúcar praticado de 2002 a 2004 (valores de junho/04) e das exportações brasileiras. Observa-se que o período de pico de safra coincide com períodos de altos fretes rodoviários. Neste período, a demanda por transporte é alta (demanda por transporte de produtos do complexo soja ainda é bastante acentuado neste período também), o que exerce pressão de alta sobre os fretes. Esta sazonalidade pode indicar falta de capacidade de armazenamento nas usinas, que exige o escoamento no momento seguinte ao da produção, pressionando os preços.

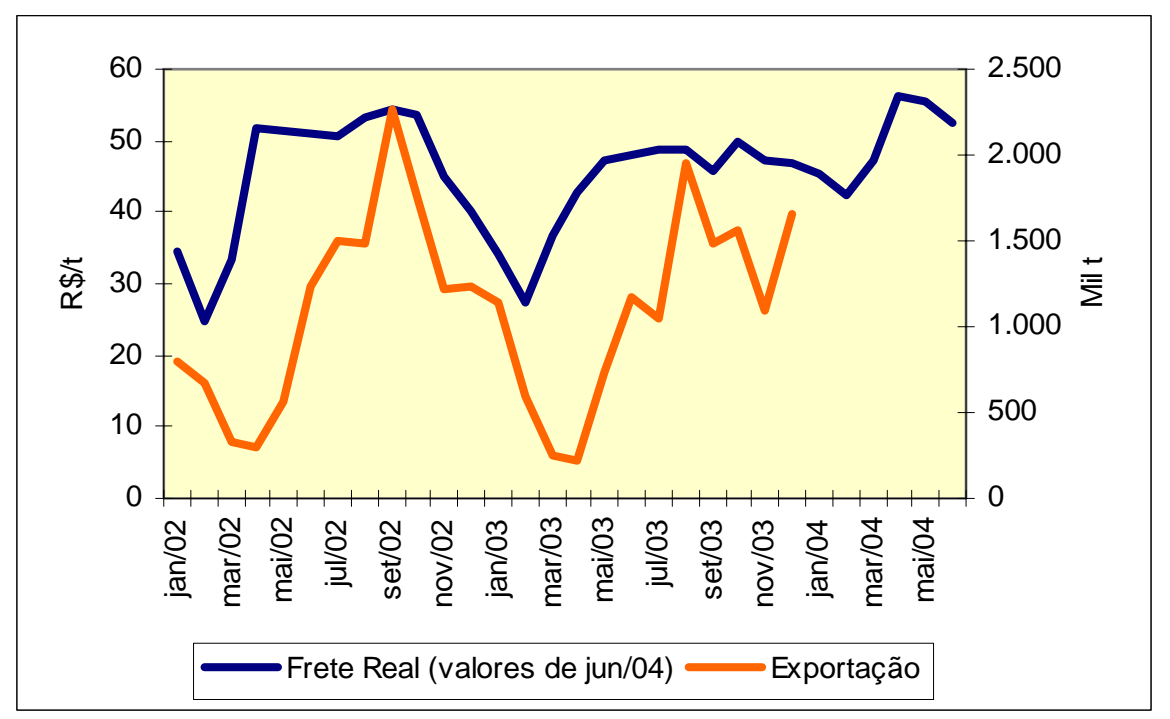

Figura 32 - Sazonalidade dos fretes de açúcar a granel praticados em São Paulo com destino ao Porto de Santos e das exportações brasileiras

Fonte: elaborado a partir de dados do SIFRECA e da UNICA (2004)

Os fretes ferroviários tendem a ser mais estáveis ao longo do ano, mas também apresentam certa sazonalidade principalmente devido à pressão dos preços dada pela concorrência com a soja pelos escassos ativos ferroviários. A Figura 33 mostra os fretes ferroviários praticados obtidos na base de dados do SIFRECA. 


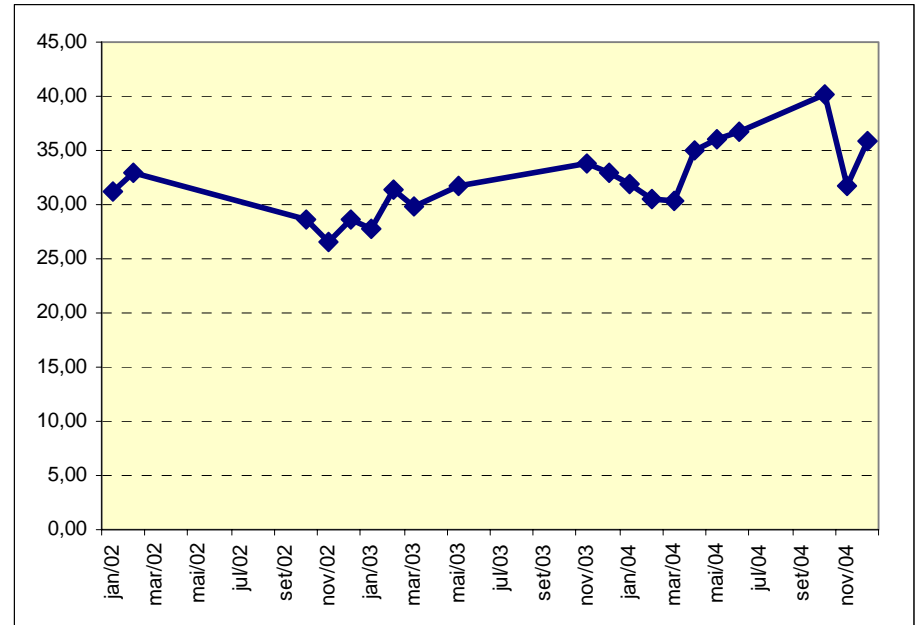

Figura 33 - Fretes ferroviários praticados no estado de São Paulo, em valores de junho de 2004 para dados de jan/02 a jun/04 e valores correntes para jun/04 a $\operatorname{dez} / 04$

Fonte: elaborado a partir de dados do SIFRECA

\subsubsection{Oferta de açúcar para exportação em São Paulo}

O estado de São Paulo foi escolhido por representar mais de $60 \%$ da produção brasileira de açúcar. A área considerada pelo trabalho responde por $80 \%$ da produção paulista, ou seja, este trabalho está focado em uma amostra que representa cerca de $50 \%$ da produção nacional de açúcar.

As capacidades de produção de açúcar das usinas foram obtidas através de informações que constam no Anuário JornalCana Centro-Sul Safra 02/03, da Procana, no site institucional das Usinas e Destilarias do Oeste Paulista (UDOP) (http://www.udop.com.br/) ou no site da própria usina, prevalecendo os números mais atualizados encontrados. A relação das usinas consideradas e suas produções estão expressas na Tabela 9.

Seguindo a tendência atual de exportação (vide Figura 12), este trabalho considerará que $60 \%$ da produção das usinas serão destinadas à exportação. Esta é uma 
simplificação que será adotada; porém sabe-se que algumas usinas são mais voltadas para o mercado interno e outras têm vocações exportadoras. De qualquer forma, a mudança do mix de produção é relativamente flexível, tanto no que se trata da substituição da produção de açúcar por álcool (e vice-versa) quanto entre os tipos de açúcar fabricados. Essa flexibilidade, assim como a variável "tempo", não estão incorporadas no modelo matemático desenvolvido, ou seja, admite-se que toda produção é escoada ao mesmo tempo ${ }^{27}$ o que, apesar de ser uma simplificação, não invalida a importância do modelo.

\footnotetext{
${ }^{27}$ Não se considera, portanto, os eventuais custos de ociosidade dos armazéns no período de entresafra. $\mathrm{Na}$ realidade, os períodos de entressafra vêm diminuindo e a comercialização do produto tende a ser realizada ao longo do ano todo.
} 
Tabela 10. Usinas consideradas no modelo matemático e suas produções de açúcar, safras $02 / 03$ ou $03 / 04$

\begin{tabular}{|c|c|c|c|c|}
\hline $\mathrm{Ui}$ & Usina & Município & $\begin{array}{l}\text { Produção } \\
\text { (mil t) }\end{array}$ & $\begin{array}{l}\text { Exportação = } \\
60 \% \text { produção }\end{array}$ \\
\hline U1 & Água Bonita & Tarumã & - & - \\
\hline $\mathrm{U} 2$ & Albertina & Sertãozinho & 151 & 90 \\
\hline $\mathrm{U} 3$ & Alcoazul & Araçatuba & 43 & 26 \\
\hline $\mathrm{U} 4$ & Alcoeste & Fernandópolis & - & - \\
\hline U5 & Alcomira (atual Mundial) & Mirandópolis & 19 & 12 \\
\hline U6 & Alta Mogiana & São Joaquim da Barra & 187 & 112 \\
\hline U7 & Alto Alegre & Presidente Prudente & 162 & 97 \\
\hline U8 & Andrade & Pitangueiras & 8 & 5 \\
\hline U9 & Aralco & Sto. Antônio do Aracanguá & 95 & 57 \\
\hline U10 & Barra Grande & Lençóis Paulista & 227 & 136 \\
\hline U11 & Bazan & Pontal & 12 & 7 \\
\hline U12 & Bela Vista & Pontal & 120 & 72 \\
\hline U13 & Benálcool & Bento de Abreu & 76 & 45 \\
\hline U14 & Bertolo & Pirangi & - & - \\
\hline $\mathrm{U} 15$ & Branco Peres & Adamantina & 33 & 20 \\
\hline U16 & Campestre & Penápolis & 56 & 34 \\
\hline $\mathrm{U} 17$ & Catanduva & Ariranha & 10 & 6 \\
\hline U18 & CBA (antiga Sanagro SP) & Icém & 38 & 23 \\
\hline U19 & Central Paulista & Jaú & 66 & 40 \\
\hline $\mathrm{U} 20$ & Centrálcool & Lucélia & 68 & 41 \\
\hline $\mathrm{U} 21$ & Cerradinho & Catanduva & 178 & 107 \\
\hline $\mathrm{U} 22$ & Clealco & Clementina & 118 & 71 \\
\hline $\mathrm{U} 23$ & Cocal & Paraguaçu Paulista & 212 & 127 \\
\hline $\mathrm{U} 24$ & Colombo & Ariranha & 279 & 167 \\
\hline $\mathrm{U} 25$ & Colorado & Guaíra & 325 & 195 \\
\hline U26 & Corona & Guariba & 467 & 280 \\
\hline $\mathrm{U} 27$ & Costa Pinto & Piracaba & 360 & 216 \\
\hline $\mathrm{U} 28$ & Da Barra & Barra Bonita & 540 & 324 \\
\hline U29 & Da Pedra & Serrana & 194 & 116 \\
\hline U30 & Da Serra & Ibaté & 200 & 120 \\
\hline U31 & Dacal & Parapuã & 21 & 12 \\
\hline $\mathrm{U} 32$ & Dalsa & Monte Aprazível & - & - \\
\hline U33 & $\mathrm{DC}$ & Dois Córregos & 160 & 96 \\
\hline U34 & Della Coletta & Bariri & - & - \\
\hline $\mathrm{U} 35$ & Destil & Itajobi & - & - \\
\hline U36 & Destivale & Araçatuba & 25 & 15 \\
\hline U37 & Diamante & Jaú & 200 & 120 \\
\hline U38 & Diana & Avanhadava & 37 & 22 \\
\hline U39 & Equipav & Promissão & 177 & 106 \\
\hline $\mathrm{U} 40$ & Ester & Cosmópolis & 105 & 63 \\
\hline U41 & Floralco & Flórida Paulista & 59 & 36 \\
\hline U42 & Furlan & Santa Barbara D'Oeste & 6 & 4 \\
\hline U43 & Galo Bravo & Ribeirão Preto & 83 & 50 \\
\hline
\end{tabular}


Tabela 10. Usinas consideradas no modelo matemático e suas produções de açúcar, safras $02 / 03$ ou $03 / 04$

\begin{tabular}{|c|c|c|c|c|}
\hline $\mathrm{Ui}$ & Usina & Município & $\begin{array}{l}\text { Produção } \\
\text { (mil t) }\end{array}$ & $\begin{array}{l}\text { Exportação = } \\
60 \% \text { produção }\end{array}$ \\
\hline U44 & Gasa & Andradina & - & - \\
\hline U45 & Grizzo & Jaú & - & - \\
\hline U46 & Guaíra & Guaíra & 165 & 99 \\
\hline U47 & Guarani (Cruz Alta) & Olímpia & 180 & 108 \\
\hline U48 & Guarani (Severínia) & Severínia & 255 & 153 \\
\hline U49 & Guaricanga & Presidente Alves & - & - \\
\hline U50 & Ibirá & Santa Rosa do Viterbo & 88 & 53 \\
\hline U51 & Ipaussu & Ipauçu & 222 & 133 \\
\hline U52 & Ipiranga (Matriz) & Descalvado & 61 & 36 \\
\hline U53 & Iracema & Iracemópolis & 163 & 98 \\
\hline U54 & Jardest & Jardinópolis & 63 & 38 \\
\hline U55 & Londra & Itaí & - & - \\
\hline U56 & Malosso & Itápolis & - & - \\
\hline U57 & Mandu & Guaíra & 121 & 73 \\
\hline U58 & Maracaí & Maracaí & 10 & 6 \\
\hline U59 & Maringá & Araraquara & 6 & 3 \\
\hline U60 & $\mathrm{MB}$ & Morro Agudo & 161 & 96 \\
\hline U61 & Moema & Orindiúva & 11 & 6 \\
\hline U62 & Moreno & Monte Aprazível & 52 & 31 \\
\hline U63 & Moreno & Luís Antônio & 194 & 116 \\
\hline U64 & Nardini & Vista Alegre do Alto & 118 & 71 \\
\hline U65 & Nossa Senhora de Aparecida (BC) & Pontal & 215 & 129 \\
\hline U66 & Nova América & Tarumã & 398 & 239 \\
\hline U67 & Paraíso Bioenergia & Brotas & - & - \\
\hline U68 & Parálcool & Paraguaçu Paulista & 3 & 2 \\
\hline U69 & Pederneiras & Tietê & - & - \\
\hline $\mathrm{U} 70$ & Petribú Paulista & Sebastianópolis do Sul & 70 & 42 \\
\hline U71 & Pioneiros & Sud Menucci & 57 & 34 \\
\hline U72 & Pitangueiras & Pitangueiras & 95 & 57 \\
\hline U73 & Pyles & Platina & - & - \\
\hline U74 & Quatá & Quatá & 99 & 59 \\
\hline U75 & Rafard & Rafard & 240 & 144 \\
\hline U76 & Santa Adélia & Jaboticabal & 146 & 87 \\
\hline U77 & Santa Cândida & Bocaina & 154 & 93 \\
\hline U78 & Santa Cruz & Américo Brasiliense & 175 & 105 \\
\hline U79 & Santa Elisa & Sertãozinho & 480 & 288 \\
\hline U80 & Santa Fé & Nova Europa & 109 & 65 \\
\hline U81 & Santa Helena & Rio das Pedras & 160 & 96 \\
\hline U82 & Santa Inês & Sertãozinho & - & - \\
\hline U83 & Santa Isabel & Novo Horionte & 269 & 161 \\
\hline U84 & Santa Luiza & Motuca & 100 & 60 \\
\hline U85 & Santa Maria & Cerquilho & 46 & 27 \\
\hline U86 & Santa Rita & Santa Rita do Passa Quatro & 5 & 3 \\
\hline
\end{tabular}


Tabela 10. Usinas consideradas no modelo matemático e suas produções de açúcar, safras $02 / 03$ ou $03 / 04$

\begin{tabular}{lllcc}
\hline Ui & \multicolumn{1}{c}{ Usina } & \multicolumn{1}{c}{ Município } & $\begin{array}{c}\text { Produção } \\
\text { (mil t) }\end{array}$ & $\begin{array}{c}\text { Exportação }= \\
60 \% \text { produção }\end{array}$ \\
\hline U87 & Santa Rosa (Boituva) & Boituva & 21 & 13 \\
U88 & Santo Antônio (USA) & Sertãozinho & 5 & 3 \\
U89 & São Carlos & Jaboticabal & 131 & 78 \\
U90 & São Domingos & Catanduva & 140 & 84 \\
U91 & São Francisco (UFRA) & Sertãozinho & 76 & 45 \\
U92 & São José & Rio das Pedras & 74 & 45 \\
U93 & São José (ZL) & Macatuba & 67 & 40 \\
U94 & São José da Estiva & Novo Horizonte & 107 & 64 \\
U95 & São Manuel & São Manuel & 125 & 75 \\
U96 & São Martinho & Pradópolis & 409 & 246 \\
U97 & Sobar & Espírito Santo do Turvo & - & - \\
U98 & Unialco & Guararapes & 145 & 87 \\
U99 & Univalem & Valparaíso & 145 & 87 \\
U100 & Vale do Rosário & Orlândia & 354 & 212 \\
U101 & Virálcool & Pitagueiras & 137 & 82 \\
U102 & Vista Alegre & Itapetininga & - & - \\
U103 & Zanin & Araraquara & 137 & 82 \\
& Total & & 11.882 & 7.129 \\
& Produção São Paulo (Safra 02/03) & & 15.171 & 8.773 \\
\hline Exportação São Paulo (2003) & & & & \\
\hline
\end{tabular}

Fonte: elaborado a partir de dados do Anuário JornalCana (2003); UDOP (2004); Cosan (2004) e sites das usinas

\subsubsection{Demanda de açúcar}

Considerou-se neste trabalho que $98 \%$ do volume de açúcar produzido para exportação no estado de São Paulo sai do país pelos portos de Santos e Paranaguá. A Tabela 10 mostra que o market share do Porto de Santos para as exportações de São Paulo gira em torno de $90 \%$ e do Porto de Paranaguá, $8 \%$, ou seja, a demanda do Porto de Santos considerada no trabalho foi de 6,4 milhões de toneladas e do Porto de Paranaguá, 600 mil toneladas, que representam, aproximadamente, os percentuais acima 
aplicados ao volume de exportação das usinas consideradas, totalizando 7 milhões de toneladas $^{28}$.

Tabela 11. Volume das exportações de açúcar de São Paulo, por principais portos, 2002 a 2004

\begin{tabular}{lccc}
\hline \multicolumn{1}{c}{ Exportação de Açúcar } & 2002 & 2003 & 2004 \\
\hline Produzido em São Paulo & 7,8 & 8,2 & 10,3 \\
Destino Santos & 1,4 & 0,5 & 0,4 \\
Destino Paranaguá & 9,4 & 8,8 & 10,9 \\
Total exportado SP & 8,2 & 8,7 & 11,0 \\
Açúcar total exportado por Santos & 2,5 & 1,7 & 1,6 \\
Açúcar total exportado por Paranaguá & 13,4 & 12,9 & 15,8 \\
Exportação açúcar brasileiro & &
\end{tabular}

Fonte: elaborado a partir de Brasil (2005)

\subsubsection{Custo e capacidade de armazenamento}

A fim de se obter um parâmetro sobre os custos operacionais de armazenagem, foi feito um contato com a gerência da CEAGESP com o intuito de se obter informações sobre os preços cobrados pela instituição para movimentação deste produto nas suas unidades armazenadoras. A informação obtida foi que o preço médio para a estocagem de açúcar a granel para o exercício de 2005 será $\mathrm{R} \$ 3,50$ / tonelada por mês. Para os serviços de recepção e expedição serão cobrados $\mathrm{R} \$ 1,32$ / tonelada recebida e R\$ 1,59 / tonelada expedida, respectivamente. Já para o serviço de descarregamento será cobrado aproximadamente $\mathrm{R} \$ 0,60 / \mathrm{t}$ para caminhão nãobasculante e, para carregamento, cerca de R $\$ 0,30$ / tonelada. Ou seja, para um mês no

\footnotetext{
${ }^{28}$ No modelo desenvolvido, oferta (7.129 mil t) é maior que a demanda (7 mil t). Portanto, para todos os cenários, é utilizada a simplificação de que 129 mil t não sairão das usinas.
} 
armazém, por exemplo, o dono da carga pagará cerca de $\mathrm{R} \$ 7,30$ / tonelada. A gerência informou ainda que os preços podem variar em função de contratos de reserva de espaço, para casos específicos.

O modelo não considera economias de escala no $\operatorname{armazém}^{29}$ e o custo foi calculado da seguinte maneira: foi adotado uma estimativa de custo de R \$ 7,00 / tonelada, multiplicou-se este valor pela capacidade dinâmica do armazém, ou seja, a movimentação de açúcar, independentemente da quantidade, gera um custo operacional fixo de armazenamento.

Dez tamanhos de armazéns foram considerados: 30, 50, 70, 100, 150, 200, 250, 300, 400 e 500 mil toneladas, que indicam para o modelo a capacidade dinâmica dos terminais. Estes tamanhos foram definidos a partir de informações de mercado sobre a capacidade estática dos armazéns existentes que operam açúcar a granel, que, em sua maioria, variam entre 30 mil toneladas e 100 mil toneladas. As alternativas, portanto, contemplam diferentes capacidades que consideram giros dos armazéns entre 1 e 5 vezes.

Quanto aos dados de custo portuário, foram obtidas informações junto a agentes do setor sucroalcooleiro que sugeriram que o custo por tonelada do porto de Santos gira em torno de US\$ 11,00 e o do Porto de Paranaguá aproximadamente US\$ 9,50. Para conversão em reais utilizou-se o câmbio de R\$2,65 / US\$ 1.00. Esta é também uma simplificação dado que alguns agentes possuem estrutura de armazenagem no porto e outros não, o que os diferencia bastante em termos de custos portuários

\footnotetext{
${ }^{29}$ O fato de não se considerar economias de escala no custo de operação dos armazéns pode subdimensionar os seus tamanhos. Supondo economia de escala na armazenagem, o custo unitário seria menor para armazéns maiores, já que os custos fixos seriam diluídos. Porém, para efeito de simplificação, adotou-se o custo $\mathrm{R} \$ 7,00$ / t, independente do volume movimentado pelo armazém. Apenas o cenário 3 não é afetado por esta premissa, já que não considera custos de armazenagem.
} 
incorridos. De qualquer forma, este valor é aproximado e está relacionado a quem não possui infra-estrutura própria no porto. 


\section{RESULTADOS E DISCUSSÃO}

Neste capítulo são apresentados os resultados obtidos para cada cenário considerado neste estudo. Serão analisados os fluxos de açúcar no estado de São Paulo, a escala ótima e os locais mais adequados para instalação dos armazéns que foram obtidos pelo processamento do modelo matemático de programação mista desenvolvido com o software de otimização GAMS.

Os resultados do trabalho estão sujeitos às simplificações adotadas na elaboração do modelo citadas ao longo do texto. Dentre elas as mais importantes são: 1) ofertas e demandas conhecidas: as usinas exportam $60 \%$ do que produzem e do total exportado, $90 \%$ segue para o Porto de Santos e $8 \%$ para Paranaguá; 2) não há economias de escala no transporte e no armazenamento; 3) o modelo não contempla a distribuição das exportações ao longo do tempo; 4) o custo de construção e implantação dos terminais não foi considerado. Destaca-se ainda que este trabalho não levou em conta a alternativa logística que envolve o transporte hidroviário no estado de São Paulo, por esta ser ainda muito incipiente para o caso do açúcar. Também não considera a alternativa de saída do açúcar do armazém por caminhão, pois a viabilização do transporte rodoviário não implica a concentração de carga em determinado local. 


\subsection{Cenário 1}

O cenário 1 levou em consideração a não existência prévia de armazéns intermodais concentradores de carga no estado de São Paulo e permitiu-se a instalação de apenas um terminal em cada município considerado.

A solução do problema de minimização de custos logísticos, sob as condições estipuladas, indicou que o menor custo possível para movimentar as 7 milhões de toneladas consideradas é $\mathrm{R} \$ 524.931 .810,00$. A capacidade total de armazenagem instalada foi de 4,05 milhões de toneladas e foi plenamente utilizada. As quantidades transportadas das usinas para os armazéns e para os portos pelo modal rodoviário estão apresentadas no Quadro 1. 


\begin{tabular}{|c|c|c|c|c|c|c|c|c|c|c|c|c|c|c|c|c|}
\hline \multirow{3}{*}{$\mathrm{Ui}$} & \multirow{3}{*}{ Usina } & \multirow{3}{*}{ Município } & \multicolumn{11}{|c|}{ Ponta Rodoviária } & \multicolumn{2}{|c|}{ Rodov. Direto } & \multirow{3}{*}{$\begin{array}{l}\text { Total } \\
\text { (mil t) }\end{array}$} \\
\hline & & & A1 & A2 & A3 & A4 & A5 & \begin{tabular}{|l|} 
A6 \\
\end{tabular} & \begin{tabular}{|l|} 
A7 \\
\end{tabular} & \begin{tabular}{|l|} 
A8 \\
\end{tabular} & A9 & \begin{tabular}{|l|} 
A10 \\
\end{tabular} & A11 & \multirow{2}{*}{ Santos } & \multirow{2}{*}{\begin{tabular}{|c|} 
Parana \\
guá
\end{tabular}} & \\
\hline & & & \begin{tabular}{|l|} 
Araçat \\
uba
\end{tabular} & $\begin{array}{l}\text { Araraq } \\
\text { uara }\end{array}$ & \begin{tabular}{|l|}
$\begin{array}{l}\text { Barrett } \\
\text { os }\end{array}$ \\
\end{tabular} & Bauru & \begin{tabular}{|l|}
$\begin{array}{l}\text { Boitu } \\
\text { va }\end{array}$ \\
\end{tabular} & \begin{tabular}{|l|l|}
$\begin{array}{l}\text { Eernand } \\
\text { oppolis }\end{array}$ \\
\end{tabular} & \begin{tabular}{|l|} 
Palmit \\
al
\end{tabular} & $\begin{array}{l}\text { Pradóp } \\
\text { olis }\end{array}$ & \begin{tabular}{|l}
$\begin{array}{l}\text { Ribeirão } \\
\text { Preto }\end{array}$ \\
\end{tabular} & $\begin{array}{l}\text { Santa } \\
\text { Adélia }\end{array}$ & Tupã & & & \\
\hline U2 & Albertina & Sertãozinho & & & & & & & & & 90 & & & & & 90 \\
\hline U3 & Alcoazul & Araçatuba & 26 & & & & & & & & & & & & & 26 \\
\hline U5 & Alcomira & Mirandópolis & 12 & & & & & & & & & & & & & 12 \\
\hline U6 & Alta Mogiana & São Joaquim da Barra & & & & & & & & & & & & 112 & & 112 \\
\hline U7 & Alto Alegre & Presidente Prudente & & & & & & & & & & & 97 & & & 97 \\
\hline U8 & Andrade & Pitangueiras & & & & & & & & & & & & 5 & & 5 \\
\hline U9 & Aralco & Sto. Antônio do Aracanguá & 57 & & & & & & & & & & & & & 57 \\
\hline U10 & Barra Grande & Lençóis Paulista & & & & 136 & & & & & & & & & & 136 \\
\hline U11 & Bazan & Pontal & & & & & & & & & & & & 7 & & 7 \\
\hline U12 & Bela Vista & Pontal & & & & & & & & & & & & 72 & & 72 \\
\hline U13 & Benálcool & Bento de Abreu & 45 & & & & & & & & & & & & & 45 \\
\hline U15 & Branco Peres & Adamantina & & & & & & & & & & & 20 & & & 20 \\
\hline U16 & Campestre & Penápolis & 34 & & & & & & & & & & & & & 34 \\
\hline U17 & Catanduva & Ariranha & & & & & & & & & & 6 & & & & 6 \\
\hline U18 & CBA (antiga Sanagro & Icém & & & 23 & & & & & & & & & & & 23 \\
\hline U19 & Central Paulista & Jaú & & & & 31 & & & & & & & & 9 & & 40 \\
\hline U20 & Centrálcool & Lucélia & & & & & & & & & & & 41 & & & 41 \\
\hline U21 & Cerradinho & Catanduva & & & & & & & & & & 107 & & & & 107 \\
\hline U22 & Clealco & Clementina & 10 & & & & & & & & & & 61 & & & 71 \\
\hline U23 & Cocal & Paraguaçu Paulista & & & & & & & 127 & & & & & & & 127 \\
\hline U24 & Colombo & Ariranha & & & & & & & & & & 167 & & & & 167 \\
\hline U25 & Colorado & Guaíra & & & 195 & & & & & & & & & 52 & & 247 \\
\hline U26 & Corona & Guariba & & & & & & & & 274 & & & & 6 & & 280 \\
\hline U27 & Costa Pinto & Piracaba & & & & & & & & & & & & 216 & & 216 \\
\hline U28 & Da Barra & Barra Bonita & & & & & & & & & & & & 324 & & 324 \\
\hline U29 & Da Pedra & Serrana & & & & & & & & & & & & 116 & & 116 \\
\hline U30 & Da Serra & Ibaté & & & & & & & & & & & & 120 & & 120 \\
\hline U31 & Dacal & Parapuã & & & & & & & & & & & 12 & & & 12 \\
\hline U33 & $\mathrm{DC}$ & Dois Córregos & & & & & & & & & & & & 96 & & 96 \\
\hline U36 & Destivale & Araçatuba & 15 & & & & & & & & & & & & & 15 \\
\hline U37 & Diamante & Jaú & & & & & & & & & & & & 120 & & 120 \\
\hline U38 & Diana & Avanhadava & & & & & & & & & & & & 22 & & 22 \\
\hline U39 & Equipav & Promissão & 95 & & & & & & & & & & & 11 & & 106 \\
\hline U40 & Ester & Cosmópolis & & & & & & & & & & & & 63 & & 63 \\
\hline U41 & Floralco & Flórida Paulista & & & & & & & & & & & 36 & & & 36 \\
\hline U42 & Furlan & Santa Barbara D'Oeste & & & & & & & & & & & & 4 & & 4 \\
\hline U43 & Galo Bravo & Ribeirão Preto & & & & & & & & & 36 & & & 14 & & 50 \\
\hline U46 & Guaíra & Guaíra & & & 21 & & & & & & & & & 99 & & 120 \\
\hline U47 & Guarani (Cruz Alta) & Olímpia & & & 108 & & & & & & & & & & & 108 \\
\hline U48 & Guarani (Severínia) & Severínia & & & 153 & & & & & & & & & & & 153 \\
\hline U50 & Ibirá & Santa Rosa do Viterbo & & & & & & & & & & & & 53 & & 53 \\
\hline U51 & Ipaussu & Ipauçu & & & & & & & & & & & & & 133 & 133 \\
\hline \begin{tabular}{|l|l} 
U52 \\
\end{tabular} & Ipiranga (Matriz) & Descalvado & & & & & & & & & & & & 36 & & 36 \\
\hline U53 & Iracema & Iracemópolis & & & & & & & & & & & & 98 & & 98 \\
\hline U54 & Jardest & Jardinópolis & & & & & & & & & 38 & & & & & 38 \\
\hline
\end{tabular}

Quadro 1 - Volume de açúcar transportado pelo modal rodoviário, em mil toneladas, cenário 1 


\begin{tabular}{|c|c|c|c|c|c|c|c|c|c|c|c|c|c|c|c|c|}
\hline \multirow{3}{*}{ Ui } & \multirow{3}{*}{ Usina } & \multirow{3}{*}{ Município } & \multicolumn{11}{|c|}{ Ponta Rodoviária } & \multicolumn{2}{|c|}{ Rodov. Direto } & \multirow{3}{*}{$\begin{array}{l}\text { Total } \\
\text { (mil t) }\end{array}$} \\
\hline & & & A1 & A2 & A3 & $\mathrm{A4}$ & A5 & A6 & \begin{tabular}{|l|} 
A7 \\
\end{tabular} & \begin{tabular}{|l|} 
A8 \\
\end{tabular} & \begin{tabular}{|l|} 
A9 \\
\end{tabular} & \begin{tabular}{|l|}
$\mathrm{A10}$ \\
\end{tabular} & A11 & \multirow[b]{2}{*}{ Santos } & \multirow[b]{2}{*}{$\begin{array}{c}\text { Parana } \\
\text { guá }\end{array}$} & \\
\hline & & & \begin{tabular}{|l|}
$\begin{array}{l}\text { Araçat } \\
\text { uba }\end{array}$ \\
\end{tabular} & \begin{tabular}{|l|} 
Araraq \\
uara \\
\end{tabular} & \begin{tabular}{|l|}
$\begin{array}{l}\text { Barret } \\
\text { os }\end{array}$ \\
\end{tabular} & Bauru & \begin{tabular}{|l|} 
Boitu \\
va
\end{tabular} & $\begin{array}{l}\text { Fernand } \\
\text { opplis }\end{array}$ & $\begin{array}{l}\text { Palmit } \\
\text { al }\end{array}$ & \begin{tabular}{|l|}
$\begin{array}{l}\text { Pradóp } \\
\text { olis }\end{array}$ \\
\end{tabular} & \begin{tabular}{|l|}
$\begin{array}{l}\text { Ribeirà } \\
\text { Preto }\end{array}$ \\
\end{tabular} & \begin{tabular}{|l|} 
Santa \\
Adélia \\
\end{tabular} & Tupã & & & \\
\hline U58 & Maracaí & Maracaí & & & & & & & 6 & & & & & & & \\
\hline U59 & Maringá & Araraquara & & 3 & & & & & & & & & & & & \\
\hline $\mathrm{U} 60$ & MB & Morro Agudo & & & & & & & & & & & & 96 & & 96 \\
\hline U62 & Moreno & Monte Aprazivel & & & & & & 6 & & & & & & & 25 & 31 \\
\hline U63 & Moreno & Luís Antônio & & & & & & & & & & & & 116 & & 116 \\
\hline U64 & Nardini & Vista Alegre do Alto & & & & & & & & & & 71 & & & & 71 \\
\hline U65 & Nossa Senhora de Apar & Pontal & & & & & & & & & & & & 129 & & 129 \\
\hline U66 & Nova América & Tarumã & & & & & & & 239 & & & & & & & 239 \\
\hline $\mathrm{U} 68$ & Parálcool & Paraguaçu Paulista & & & & & & & 2 & & & & & & & . \\
\hline $\mathrm{U} 70$ & Petribú Paulista & Sebastianópolis do Sul & & & & & & 42 & & & & & & & & 42 \\
\hline $\mathrm{U} 71$ & Pioneiros & Sud Menucci & 32 & & & & & 2 & & & & & & & & 34 \\
\hline $\mathrm{U} 72$ & Pitangueiras & Pitangueiras & & & & & & & & & & & & 57 & & 57 \\
\hline $\mathrm{U} 74$ & Quatá & Quatá & & & & & & & 26 & & & & 33 & & & 59 \\
\hline U75 & Rafard & Rafard & & & & & & & & & & & & 144 & & 144 \\
\hline U76 & Santa Adélia & Jaboticabal & & 87 & & & & & & & & & & & & 87 \\
\hline U77 & Santa Cândida & Bocaina & & & & 93 & & & & & & & & & & 93 \\
\hline U78 & Santa Cruz & Américo Brasiliense & & 105 & & & & & & & & & & & & 105 \\
\hline U79 & Santa Elisa & Sertãozinho & & & & & & & & & 288 & & & & & 288 \\
\hline $\mathrm{U} 80$ & Santa Fé & Nova Europa & & 65 & & & & & & & & & & & & 65 \\
\hline U81 & Santa Helena & Rio das Pedras & & & & & & & & & & & & 96 & & 96 \\
\hline U83 & Santa Isabel & Novo Horionte & & & & & & & & & & 1 & & & & 1 \\
\hline U84 & Santa Luiza & Motuca & & 60 & & & & & & & & & & & & 60 \\
\hline U85 & Santa Maria & Cerquilho & & & & & & & & & & & & 27 & & 27 \\
\hline U86 & Santa Rita & Santa Rita do Passa Quatro & & & & & & & & & & & & 3 & & 3 \\
\hline U87 & Snta Rosa (Boituva) & Boituva & & & & & & & & & & & & 13 & & 13 \\
\hline U88 & Santo Antônio (USA) & Sertãozinho & & & & & & & & & 3 & & & & & 3 \\
\hline U89 & São Carlos & Jaboticabal & & 78 & & & & & & & & & & & & 78 \\
\hline U90 & São Domingos & Catanduva & & & & & & & & & & 84 & & & & 84 \\
\hline U91 & São Francisco (UFRA) & Sertãozinho & & & & & & & & & 45 & & & & & 45 \\
\hline U92 & São José & Rio das Pedras & & & & & & & & & & & & 45 & & 45 \\
\hline U93 & São José (ZL) & Macatuba & & & & 40 & & & & & & & & & & 40 \\
\hline U94 & São José da Estiva & Novo Horizonte & & & & & & & & & & 64 & & & 42 & 106 \\
\hline U95 & São Manuel & São Manuel & & & & & & & & & & & & 75 & & 75 \\
\hline U96 & São Martinho & Pradópolis & & 20 & & & & & & 226 & & & & & & 246 \\
\hline U98 & Unialco & Guararapes & 87 & & & & & & & & & & & & & 87 \\
\hline U99 & Univalem & Valparaíso & 87 & & & & & & & & & & & & & 87 \\
\hline $\mathrm{U} 100$ & Vale do Rosário & Orlândia & & & & & & & & & & & & 212 & & 212 \\
\hline U101 & Virálcool & Pitagueiras & & & & & & & & & & & & 82 & & 82 \\
\hline U103 & Zanin & Araraquara & & 82 & & & & & & & & & & & & 82 \\
\hline & Total ( & $(\mathrm{mil} \mathrm{t})$ & 500 & 500 & 500 & $300 \mid$ & 0 & 50 & 400 & 500 & 500 & 500 & 300 & 2750 & 200 & 7000 \\
\hline
\end{tabular}

Quadro 1 - Volume de açúcar transportado pelo modal rodoviário, em mil toneladas, cenário 1

Fonte: resultados da pesquisa 
A Figura 34 representa, geograficamente, os resultados do Quadro 1, diferenciando por cores as usinas que fornecem o açúcar que chega em cada armazém por rodovia e segue para os portos via ferrovia e também as usinas que mandam o açúcar diretamente para o porto por caminhão ${ }^{30}$.

Um caso interessante que é observado na Figura 34 é o da Usina Moreno. A minimização dos custos logísticos sugeriu que esta usina, localizada no município de Monte Aprazível, deverá enviar uma pequena parte do seu açúcar produzido para o terminal de Fernandópolis e outra parte maior para Paranaguá.

À primeira vista, a ida para Paranaguá pode parecer um pouco estranha, porém o sistema deve ser visto como um todo. Verifica-se que o tamanho ótimo para o armazém de Fernandópolis foi de 50 mil toneladas e a usina que o abastece com o menor custo é a Petribu Paulista, devido à sua proximidade, a qual fornece 42 mil t. O segundo menor custo seria da Usina Moreno, porém esta só atende ao volume restante, qual seja, 8 mil t. A outra alternativa mais próxima que utilizaria o transporte ferroviário seria a utilização do terminal de Araçatuba, porém, outras usinas mais próximas abastecem este armazém a um custo menor. A terceira alternativa de menor custo é a que considera o transporte rodoviário direto para o Porto de Paranaguá ${ }^{31}$, destino das 25 mil t restantes da Usina Moreno.

\footnotetext{
${ }^{30}$ As cores representam o local para onde as usinas enviaram a maior parte do seu açúcar, pois podem mandar para mais de um armazém / porto.

${ }^{31}$ Santos, apesar de mais próximo, possui um frete rodoviário maior que para Paranaguá e, além disso, Paranaguá possui um custo portuário menor.
} 


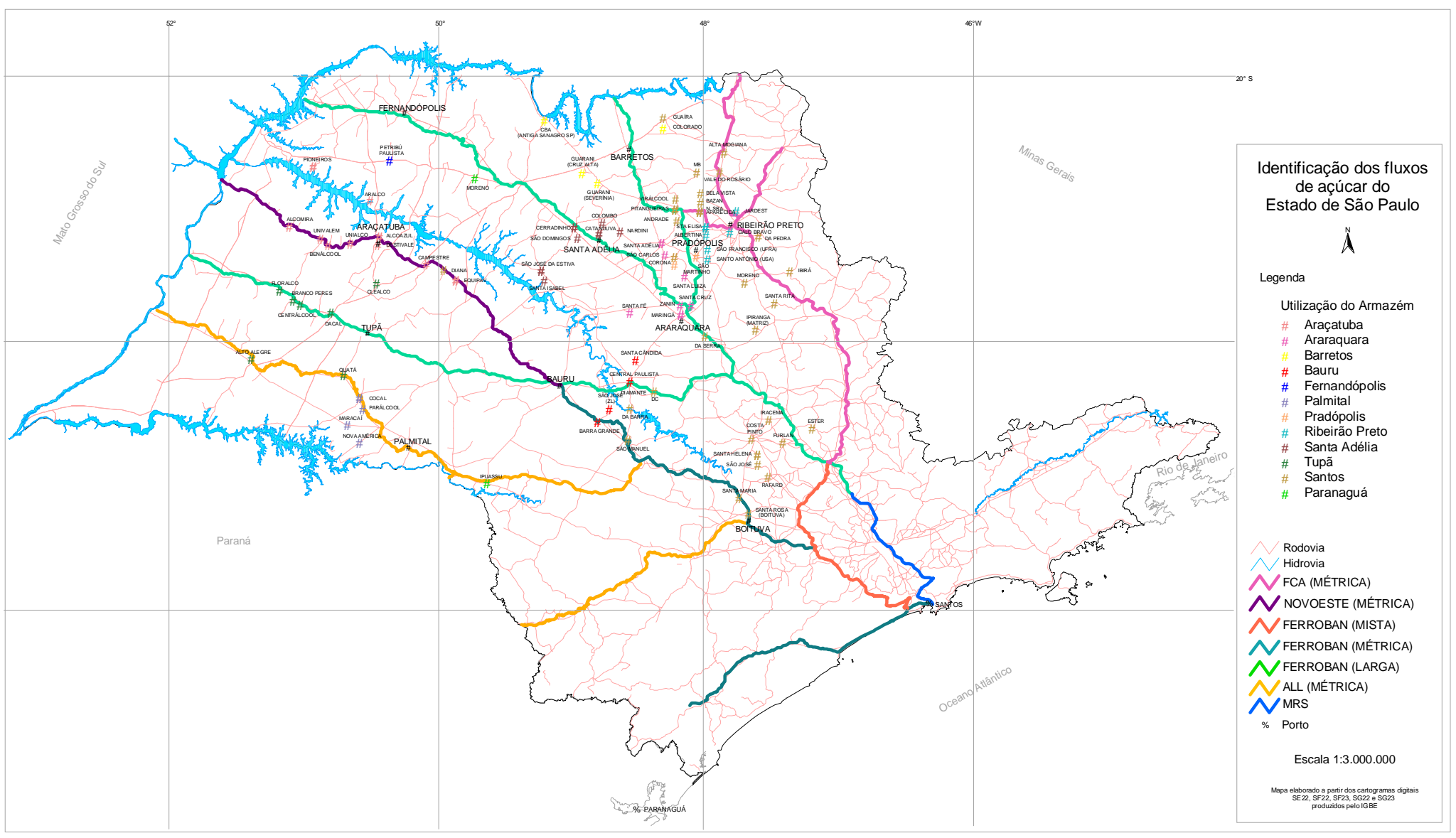

Figura 34 - Configuração dos fluxos ótimos de açúcar - CENÁRIO 1 
As maiores distâncias percorridas pelo açúcar que se destina aos terminais (pontas rodoviárias) giram em torno de 100 quilômetros (Pioneiros - Araçatuba, Alto Alegre - Tupã, por exemplo). Os maiores percursos para alcançar um terminal ocorrem no oeste do estado, o que já era esperado dado que nas áreas mais tradicionais há grande concentração de usinas e, com isso, a capacidade dos terminais é atingida pela produção de unidades próximas ao terminal, além de refletir também o menor custo unitário de transporte ferroviário para longas distâncias, diminuindo assim o custo relativo das rotas com origem no terminal e destino aos portos.

Quanto aos fluxos com destino direto ao Porto de Santos, observa-se que a origem mais distante está a cerca de $500 \mathrm{~km}$ (Usinas Diana e Guaíra). A maioria das usinas que atende a demanda do porto por rodovia, segundo os resultados do modelo, está localizada nas áreas de influência de Ribeirão Preto e de Boituva. Já o Porto de Paranaguá é atendido pela produção total da Usina Ipaussu (Ipauçu) e parte da produção das usinas Moreno (Monte Aprazível) e São José da Estiva (Novo Horizonte). Para estas últimas individualmente, a alternativa de menor custo seria através dos terminais de Fernandópolis e Santa Adélia, respectivamente. Entretanto, a capacidade máxima ótima de movimentação destes terminais foi atingida com a oferta de usinas com custos de ponta rodoviária mais baixos, tornando viável, desta forma, a alternativa de transporte rodoviário direto para Paranaguá.

No que tange ao tamanho das plantas, o modelo determinou que, para atingir o custo mínimo de movimentação do açúcar proveniente das usinas consideradas, deveriam ser instalados armazéns de 500 mil toneladas nos municípios de Araçatuba, Araraquara, Barretos, Pradópolis, Ribeirão Preto e Santa Adélia. Além disso, um terminal capaz de movimentar 400 mil toneladas deveria ser instalado em Palmital, outros dois de 300 mil toneladas deveriam ser instalados em Bauru e Tupã e, finalmente, um de 50 mil toneladas em Fernandópolis (vide Quadro 2). 


\begin{tabular}{|l|l|c|c|c|c|}
\hline \multirow{2}{*}{ Ai } & \multirow{2}{*}{ Município } & T2 & T8 & T9 & T10 \\
\cline { 3 - 6 } & & $50 \mathrm{mil} \mathrm{t}$ & $300 \mathrm{mil} \mathrm{t}$ & $400 \mathrm{mil} \mathrm{t}$ & $500 \mathrm{mil} \mathrm{t}$ \\
\hline A1 & Araçatuba & & & & 1 \\
\hline A2 & Araraquara & & & & 1 \\
\hline A3 & Barretos & & & & 1 \\
\hline A4 & Bauru & & 1 & & \\
\hline A6 & Fernandópolis & 1 & & & \\
\hline A7 & Palmital & & & 1 & \\
\hline A8 & Pradópolis & & & & 1 \\
\hline A9 & Ribeirão Preto & & & & 1 \\
\hline A10 & Santa Adélia & & & & 1 \\
\hline A11 & Tupã & & 1 & & \\
\hline
\end{tabular}

Quadro 2 - Número e tamanho de armazéns instalados, cenário 1

Fonte: resultados da pesquisa

Algumas observações interessantes podem ser feitas a partir da análise do Quadro 2. Os maiores armazéns estão localizados nas regiões nordeste e centro-norte do estado (Ribeirão Preto, Pradópolis, Santa Adélia, Araraquara e Barretos), área mais tradicional e com maior produção de açúcar. Além desses, foi estabelecido um terminal em Araçatuba, dando indicações que esta região de nova fronteira agrícola para cana já comporta um grande terminal. O estabelecimento de um armazém em cada uma das áreas influência de Tupã e Palmital (que possuem uma grande área de sobreposição) mostrou-se mais interessante que o estabelecimento de um armazém grande em apenas um deles.

Outro resultado importante obtido foi a não instalação de terminal em Boituva. Isso sugere que realmente pode haver maior competitividade do transporte rodoviário, frente à alternativa intermodal, a curtas distâncias. Quanto ao terminal de Fernandópolis, o modelo determinou que a unidade armazenadora deste município tivesse capacidade de 50 mil toneladas, o que reflete a baixa produção da área de influência deste município no estado de São Paulo. Entretanto, mesmo assim, o modelo 
indicou que a instalação de armazém neste local é economicamente mais vantajosa do que a ida do açúcar pela rodovia da usina até o Porto.

O Quadro 3 mostra o fluxo ferroviário de açúcar. Todo açúcar que entra no armazém sai via ferrovia (esta é uma premissa do modelo!). Os dados mostram que todo o volume de açúcar que se destinou ao terminal de Palmital vai ser encaminhado para o porto de Paranaguá.

\begin{tabular}{|c|c|c|c|}
\hline \multirow{2}{*}{$\mathbf{A i}$} & \multirow{2}{*}{ Município } & P1 & P2 \\
\hline & & Santos & Paranaguá \\
\hline A1 & Araçatuba & 500 & \\
\hline A2 & Araraquara & 500 & \\
\hline A3 & Barretos & 500 & \\
\hline A4 & Bauru & 300 & \\
\hline A6 & Fernandópolis & 50 & \\
\hline A7 & Palmital & & 400 \\
\hline A8 & Pradópolis & 500 & \\
\hline A9 & Ribeirão Preto & 500 & \\
\hline A10 & Santa Adélia & 500 & \\
\hline A11 & Tupã & 300 & \\
\hline & Total & 3650 & 400 \\
\hline
\end{tabular}

Quadro 3 - Fluxos ferroviários de açúcar no estado de São Paulo Fonte: resultados da pesquisa

Finalmente, os resultados do cenário 1 permitem concluir que os dois portos serão abastecidos tanto por via rodoviária quanto por via ferroviária, sendo que $57 \%$ da demanda de Santos e 67\% da demanda de Paranaguá serão atendidas por ferrovia.

Dado que, em 2004, o estado de São Paulo exportou 10,3 milhões de toneladas de açúcar via Santos e a Brasil Ferrovias entregou pouco mais de 1 milhão de toneladas do produto neste porto, pode-se concluir que o market share atual da ferrovia no Porto de Santos para o açúcar é, atualmente, da ordem de 10\%. 
Portanto, os resultados deste modelo indicam que o transporte ferroviário de açúcar é bastante competitivo e que sua participação nas exportações de açúcar de São Paulo tende a crescer. Entretanto, ressalta-se que há espaço para atuação dos dois tipos de transporte, cada um tirando proveito de suas vantagens comparativas advindas de suas características intrínsecas, já citadas neste trabalho.

\subsection{Cenário 2}

O cenário 2 difere do primeiro cenário ao permitir a instalação de até dois terminais em cada município.

O custo mínimo para o transporte do açúcar de São Paulo para Santos e Paranaguá obtido como resultado deste cenário foi de $\mathrm{R} \$ 515.692 .610,00$, valor $2 \%$ mais baixo que o do cenário anterior. A capacidade de armazenagem total instalada foi de 5,4 milhões de toneladas e foi plenamente utilizada. O Quadro 4 apresenta os fluxos percorridos pela carga e a ocupação dos armazéns. 


\begin{tabular}{|c|c|c|c|c|c|c|c|c|c|c|c|c|c|c|c|c|}
\hline \multirow[b]{2}{*}{ Ui } & \multirow[b]{2}{*}{ Usina } & \multirow[b]{2}{*}{ Município } & \multicolumn{11}{|c|}{ Ponta Rodoviária } & \multicolumn{2}{|c|}{ Rodov. Direto } & \multirow[b]{2}{*}{$\begin{array}{c}\text { Total } \\
\text { (mil t) }\end{array}$} \\
\hline & & & \begin{tabular}{|l|}
$\mathbf{A} 1$ \\
$\begin{array}{l}\text { Aracat } \\
\text { uba }\end{array}$ \\
\end{tabular} & \begin{tabular}{|l|} 
A2 \\
$\begin{array}{l}\text { Araraq } \\
\text { uara }\end{array}$ \\
\end{tabular} & \begin{tabular}{|l|} 
A3 \\
$\begin{array}{l}\text { Barret } \\
\text { os }\end{array}$ \\
\end{tabular} & \begin{tabular}{|c|} 
A4 \\
Bauru \\
\end{tabular} & \begin{tabular}{|l|} 
A5 \\
Boitu \\
va
\end{tabular} & \begin{tabular}{|c|} 
A6 \\
$\begin{array}{l}\text { Fernand } \\
\text { opolis }\end{array}$ \\
\end{tabular} & \begin{tabular}{|l|} 
A7 \\
Palmit \\
al
\end{tabular} & \begin{tabular}{|l|} 
A8 \\
it Pradóp \\
olis
\end{tabular} & \begin{tabular}{|l|} 
A99 \\
$\begin{array}{l}\text { Riberia } \\
\text { Pretto }\end{array}$
\end{tabular} & \begin{tabular}{|l|l|} 
A10 \\
$\begin{array}{l}\text { Santa } \\
\text { Adelia }\end{array}$
\end{tabular} & \begin{tabular}{|l|l|}
$\mathbf{0}$ & 111 \\
ia & Tupã \\
\end{tabular} & Santos & \begin{tabular}{|c|}
$\begin{array}{c}\text { Paranag } \\
\text { uá }\end{array}$ \\
\end{tabular} & \\
\hline $\mathrm{U} 2$ & Albertina & Sertãozinho & & & & & & & & 90 & & & & & & 90 \\
\hline U3 & Alcoazul & Araçatuba & 26 & & & & & & & & & & & & & 26 \\
\hline U5 & Alcomira & Mirandópolis & 4 & & & & & & & & & & & & & 4 \\
\hline $\mathrm{U} 6$ & Alta Mogiana & São Joaquim da Barra & & & & & & & & & 112 & & & & & 112 \\
\hline U7 & Alto Alegre & Presidente Prudente & & & & & & & 17 & & & & 71 & & & 88 \\
\hline U8 & Andrade & Pitangueiras & & & & & & & & 5 & & & & & & 5 \\
\hline U9 & Aralco & Sto. Antônio do Aracanguá & 57 & & & & & & & & & & & & & 57 \\
\hline $\mathrm{U} 10$ & Barra Grande & Lençóis Paulista & & & & 136 & & & & . & & & & & & 136 \\
\hline U11 & Bazan & Pontal & & & & & & & & 7 & & & & & & 7 \\
\hline U12 & Bela Vista & Pontal & & & & & & & & 72 & & & & & & 72 \\
\hline U13 & Benálcool & Bento de Abreu & 45 & & & & & & & & & & & & & 45 \\
\hline U15 & Branco Peres & Adamantina & & & & & & & & & & & 20 & & & 20 \\
\hline U16 & Campestre & Penápolis & 34 & & & & & & & & & & & & & 34 \\
\hline U17 & Catanduva & Ariranha & & & & & & & & & & 6 & 6 & & & 6 \\
\hline U18 & CBA (antiga Sanagro SP) & Icém & & & 12 & & & & & & & & & & & 12 \\
\hline U19 & Central Paulista & Jaú & & & & 40 & & & & & & & & & & 40 \\
\hline $\mathrm{U} 20$ & Centrálcool & Lucélia & & & & & & & & & & & 41 & & & 41 \\
\hline U21 & Cerradinho & Catanduva & & & & & & & & & & 107 & & & & 107 \\
\hline U22 & Clealco & Clementina & 71 & & & & & & & & & & & & & 71 \\
\hline $\mathrm{U} 23$ & Cocal & Paraguaçu Paulista & & & & & & & 127 & & & & & & & 127 \\
\hline $\mathrm{U} 24$ & Colombo & Ariranha & & & & & & & & & & 167 & 67 & & & 167 \\
\hline U25 & Colorado & Guaira & & & 195 & & & & & & & & & & & 195 \\
\hline $\mathrm{U} 26$ & Corona & Guariba & & & & & & & & 280 & & & & & & 280 \\
\hline U27 & Costa Pinto & Piracaba & & & & & & & & & & & & 216 & & 216 \\
\hline U28 & Da Barra & Barra Bonita & & & & 4 & & & & & & & & 320 & & 324 \\
\hline U29 & Da Pedra & Serrana & & & & & & & & & 116 & & & & & 116 \\
\hline U30 & Da Serra & Ibaté & & 120 & & & & & & & & & & & & 120 \\
\hline U31 & Dacal & Parapuã & & & & & & & & & & & 12 & & & 12 \\
\hline U33 & DC & Dois Córregos & & & & & & & & & & & & 96 & & 96 \\
\hline U36 & Destivale & Araçatuba & 15 & & & & & & & & & & & & & 15 \\
\hline U37 & Diamante & Jaú & & 79 & & & & & & & & & & 41 & & 120 \\
\hline $\mathrm{U} 38$ & Diana & Avanhadava & 18 & & & & & & & & & & & 4 & & 22 \\
\hline U39 & Equipav & Promissão & 106 & & & & & & & & & & & & & 106 \\
\hline U40 & Ester & Cosmópolis & & & & & & & & & & & & 63 & & 63 \\
\hline U41 & Floralco & Flórida Paulista & & & & & & & & & & & 36 & & & 36 \\
\hline U42 & Furlan & Santa Barbara D'Oeste & & & & & & & & & & & & 4 & & 4 \\
\hline U43 & Galo Bravo & Ribeirão Preto & & & & & & & & & 50 & & & & & 50 \\
\hline U46 & Guaíra & Guaíra & & & 99 & & & & & & & & & & & 99 \\
\hline U47 & Guarani (Cruz Alta) & Olimpia & & & 108 & & & & & & & & & & & 108 \\
\hline $\mathrm{U} 48$ & Guarani (Severínia) & Severínia & & & 113 & & & & & & & 40 & 40 & & & 153 \\
\hline U50 & Ibirá & Santa Rosa do Viterbo & & & & & & & & & & & & 53 & & 53 \\
\hline U51 & Ipaussu & Ipauçu & & & & & & & & & & & & & 133 & 133 \\
\hline $\mathrm{U} 52$ & Ipiranga (Matriz) & Descalvado & & & & & & & & & & & & 36 & & 36 \\
\hline $\mathrm{U} 53$ & Iracema & Iracemópolis & & & & & & & & & & & & 98 & & 98 \\
\hline U54 & Jardest & Jardinópolis & & & & & & & & & 38 & & & & & 38 \\
\hline
\end{tabular}

Quadro 4 - Volume de açúcar transportado pelo modal rodoviário, em mil toneladas, cenário 2 


\begin{tabular}{|c|c|c|c|c|c|c|c|c|c|c|c|c|c|c|c|c|}
\hline \multirow{3}{*}{$\mathrm{Ui}$} & \multirow{3}{*}{ Usina } & \multirow{3}{*}{ Município } & \multicolumn{11}{|c|}{ Ponta Rodoviária } & \multicolumn{2}{|c|}{ Rodov. Direto } & \multirow{3}{*}{$\begin{array}{l}\text { Total } \\
\text { (mil t) }\end{array}$} \\
\hline & & & A1 & $\mathrm{A} 2$ & $\mathrm{~A} 3$ & $\mathrm{~A} 4$ & $\mathrm{~A} 5$ & \begin{tabular}{|l|} 
A6 \\
\end{tabular} & \begin{tabular}{|l} 
A7 \\
\end{tabular} & \begin{tabular}{|l} 
A8 \\
\end{tabular} & A9 & A10 & A11 & \multirow{2}{*}{ Santos } & \multirow{2}{*}{$\begin{array}{c}\text { Parana } \\
\text { guá }\end{array}$} & \\
\hline & & & \begin{tabular}{|l|} 
Araçat \\
uba
\end{tabular} & \begin{tabular}{|l|} 
Araraa \\
uara
\end{tabular} & \begin{tabular}{|l|}
$\begin{array}{l}\text { Barret } \\
\text { os }\end{array}$ \\
\end{tabular} & Bauru & $\begin{array}{l}\text { Boituv } \\
\text { a }\end{array}$ & \begin{tabular}{|l} 
Fernand \\
oppolis
\end{tabular} & \begin{tabular}{|l|} 
Palmit \\
al \\
\end{tabular} & $\begin{array}{l}\text { Pradópo } \\
\text { lis } \\
\end{array}$ & $\begin{array}{l}\text { Ribeirão } \\
\text { Preto } \\
\end{array}$ & \begin{tabular}{|l|} 
Santa \\
Adélia \\
\end{tabular} & & & & \\
\hline U57 & Mandu & Guaíra & & & 73 & & & & & & & & & & & 73 \\
\hline U58 & Maracaí & Maracaí & & & & & & & 6 & & & & & & & 6 \\
\hline U59 & Maringá & Araraquara & & 3 & & & & & & & & & & & & \\
\hline U60 & $\mathrm{MB}$ & Morro Agudo & & & & & & & & & 96 & & & & & 96 \\
\hline $\mathrm{U} 62$ & Moreno & Monte Aprazível & & & & & & & & & & & & & 17 & 17 \\
\hline $\mathrm{U} 63$ & Moreno & Luís Antônio & & & & & & & & & & & & 116 & & 116 \\
\hline U64 & Nardini & Vista Alegre do Alto & & & & & & & & & & 71 & & & & 71 \\
\hline $\mathrm{U} 65$ & Nossa Senhora de Aparecida (BC & Pontal & & & & & & & & 129 & & & & & & 129 \\
\hline U66 & Nova América & Tarumã & & & & & & & 239 & & & & & & & 239 \\
\hline U68 & Parálcool & Paraguaçu Paulista & & & & & & & 2 & & & & & & & \\
\hline U72 & Pitangueiras & Pitangueiras & & 46 & & & & & & 11 & & & & & & 57 \\
\hline U74 & Quatá & Quatá & & & & & & & 59 & & & & & & & 59 \\
\hline U75 & Rafard & Rafard & & & & & & & & & & & & 144 & & 144 \\
\hline U76 & Santa Adélia & Jaboticabal & & 87 & & & & & & & & & & & & 87 \\
\hline U77 & Santa Cândida & Bocaina & & 93 & & & & & & & & & & & & 93 \\
\hline $\mathrm{U} 78$ & Santa Cruz & Américo Brasiliense & & 105 & & & & & & & & & & & & 105 \\
\hline U79 & Santa Elisa & Sertãozinho & & & & & & & & 60 & 228 & & & & & 288 \\
\hline $\mathrm{U} 80$ & Santa Fé & Nova Europa & & 65 & & & & & & & & & & & & 65 \\
\hline U81 & Santa Helena & Rio das Pedras & & & & & & & & & & & & 96 & & 96 \\
\hline U83 & Santa Isabel & Novo Horionte & & & & & & & & & & 161 & & & & 161 \\
\hline U84 & Santa Luiza & Motuca & & 60 & & & & & & & & & & & & 60 \\
\hline U85 & Santa Maria & Cerquilho & & & & & & & & & & & & 27] & & 27 \\
\hline U86 & Santa Rita & Santa Rita do Passa Quatro & & & & & & & & & & & & 3 & & 3 \\
\hline U87 & Snta Rosa (Boituva) & Boituva & & & & & & & & & & & & 13 & & 13 \\
\hline $\mathrm{U} 88$ & Santo Antônio (USA) & Sertãozinho & & & & & & & & & 3 & & & & & 3 \\
\hline U89 & São Carlos & Jaboticabal & & 78 & & & & & & & & & & & & 78 \\
\hline $\mathrm{U} 90$ & São Domingos & Catanduva & & & & & & & & & & 84 & & & & 84 \\
\hline U91 & São Francisco (UFRA) & Sertãozinho & & & & & & & & & 45 & & & & & 45 \\
\hline U92 & São José & Rio das Pedras & & & & & & & & & & & & 45 & & 45 \\
\hline U93 & São José (ZL) & Macatuba & & & & 40 & & & & & & & & & & 40 \\
\hline U94 & São José da Estiva & Novo Horizonte & & & & & & & & & & 64 & & & & 64 \\
\hline U95 & São Manuel & São Manuel & & & & & & & & & & & & 75 & & 75 \\
\hline $\mathrm{U} 96$ & São Martinho & Pradópolis & & & & & & & & 246 & & & & & & 246 \\
\hline U98 & Unialco & Guararapes & 87 & & & & & & & & & & & & & 87 \\
\hline U99 & Univalem & Valparaíso & 87 & & & & & & & & & & & & & 87 \\
\hline U100 & Vale do Rosário & Orlândia & & & & & & & & & 212 & & & & & 212 \\
\hline U101 & Virálcool & Pitagueiras & & 82 & & & & & & & & & & & & 82 \\
\hline U103 & Zanin & Araraquara & & 82 & & & & & & & & & & & & 82 \\
\hline & & & 550 & \begin{tabular}{|c|}
900 \\
\end{tabular} & \begin{tabular}{|l|l|}
600 \\
\end{tabular} & 220 & 0 & 0 & 450 & 900 & 900 & 700 & $\mid 180$ & 1450 & 150 & 7000 \\
\hline
\end{tabular}

Quadro 4 - Volume de açúcar transportado pelo modal rodoviário, em mil toneladas, cenário 2

Fonte: resultados da pesquisa

Apesar de os fluxos ótimos de açúcar das usinas para os armazéns apresentarem algumas mudanças em relação ao cenário anterior, em geral, o padrão de transporte continua bastante semelhante. Os resultados do Quadro 4 estão representados no mapa da Figura 35. 


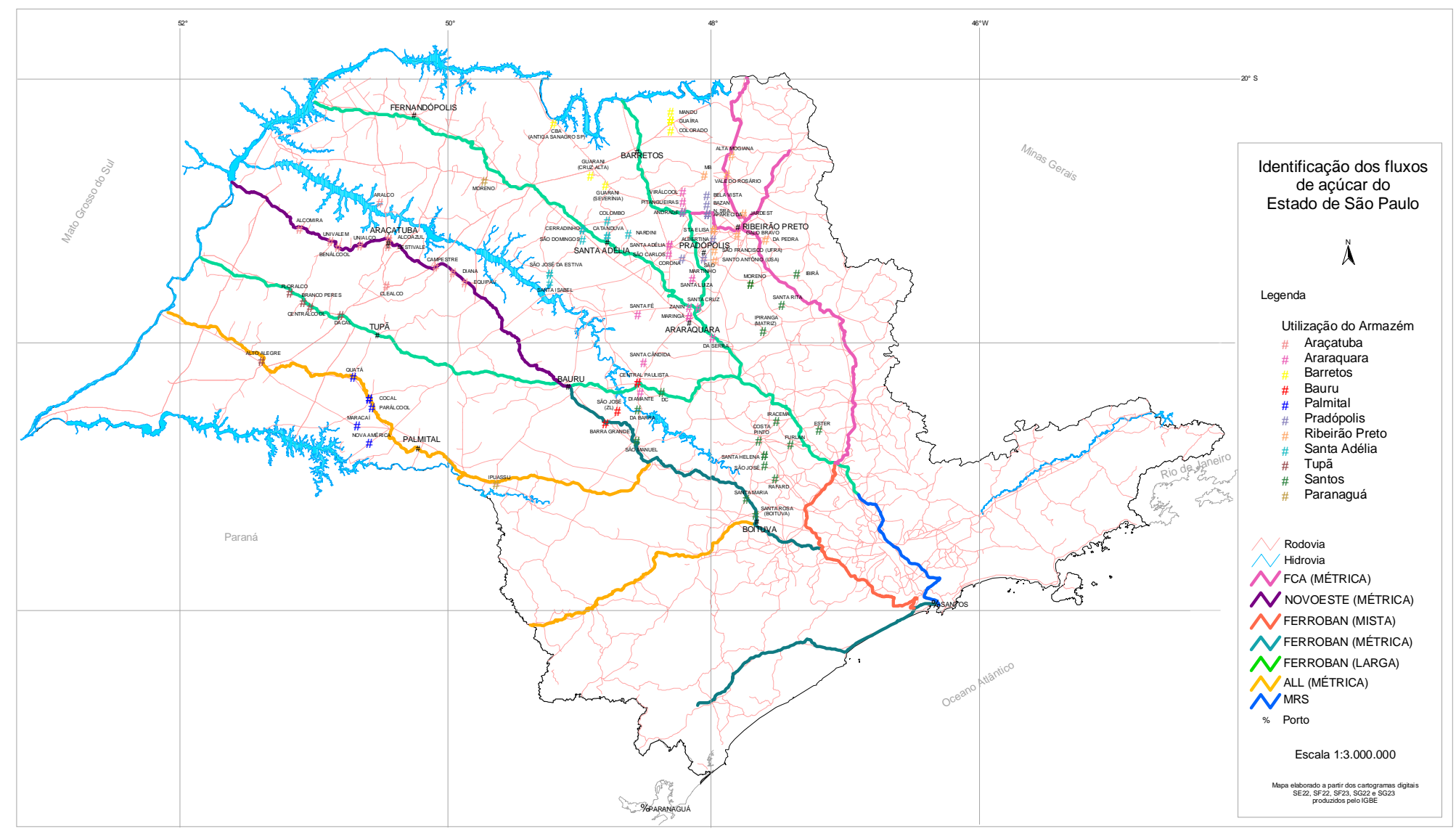

Figura 35 - Configuração dos fluxos ótimos de açúcar - CENÁRIO 2 
A análise mais importante para este cenário refere-se à localidade e tamanhos ótimos dos terminais instalados. O Quadro 5 mostra que o modelo determinou a instalação de 2 terminais em todos os municípios, exceto em Boituva e em Fernandópolis, que não aparecem com alternativas viáveis neste modelo.

No Quadro 5, as células sombreadas mostram que o modelo determinou a instalação de dois grandes terminais em Araraquara, Pradópolis e Ribeirão Preto. Esta pode ser uma indicação do grande potencial para investimento em instalação de armazéns concentradores de carga nesta região. A segunda maior capacidade total foi instalada em Santa Adélia e, em seguida, Araçatuba e Palmital, mostrando que o oeste paulista também é uma região promissora.

\begin{tabular}{|l|l|c|c|c|c|c|c|c|c|}
\hline \multirow{2}{*}{ Ai } & \multirow{2}{*}{ Município } & T1 & T2 & T3 & T4 & T5 & T8 & T9 & T10 \\
\cline { 3 - 9 } & $30 \mathrm{mil} \mathrm{t}$ & $50 \mathrm{mil} \mathrm{t}$ & $70 \mathrm{mil} \mathrm{t}$ & $100 \mathrm{mil} \mathrm{t}$ & $150 \mathrm{mil} \mathrm{t}$ & $300 \mathrm{mil} \mathrm{t}$ & $400 \mathrm{mil} \mathrm{t}$ & $500 \mathrm{mil} \mathrm{t}$ \\
\hline A1 & Araçatuba & & & & & 1 & & 1 & \\
\hline A2 & Araraquara & & & & & & & 1 & 1 \\
\hline A3 & Barretos & & & & 1 & & & & 1 \\
\hline A4 & Bauru & & & 1 & & 1 & & & \\
\hline A7 & Palmital & & 1 & & & & & 1 & \\
\hline A8 & Pradópolis & & & & & & & 1 & 1 \\
\hline A9 & Ribeirão Preto & & & & & & & 1 & 1 \\
\hline A10 & Santa Adélia & & & & & & 1 & 1 & \\
\hline A11 & Tupã & 1 & & & & 1 & & & \\
\hline
\end{tabular}

Quadro 5 - Número e tamanho de armazéns instalados, cenário 2

Fonte: resultados da pesquisa

Comparativamente ao cenário 1 , houve aumento de $36 \%$ no volume de açúcar transportado por ferrovia com destino a Santos e de $12,5 \%$ no volume que segue para Paranaguá (vide Quadro 6). O market share da ferrovia em relação à rodovia nos portos é ainda maior e, no caso de Santos, passa a ser de $77 \%$. 
A distância máxima percorrida por caminhão diretamente para o porto de Santos cai para $335 \mathrm{~km}$ (Usina Ibirá de Santa Rosa do Viterbo), indicando que se houver capacidade adicional de armazenagem, haverá aumento da utilização da alternativa intermodal e queda do custo total logístico.

\begin{tabular}{|l|l|c|c|}
\hline \multirow{2}{*}{ Ai } & \multirow{2}{*}{ Município } & P1 & P2 \\
\cline { 3 - 4 } & & Santos & Paranaguá \\
\hline A1 & Araçatuba & 550 & \\
\hline A2 & Araraquara & 900 & \\
\hline A3 & Barretos & 600 & \\
\hline A4 & Bauru & 220 & \\
\hline A7 & Palmital & & 450 \\
\hline A8 & Pradópolis & 900 & \\
\hline A9 & Ribeirão Preto & 900 & \\
\hline A10 & Santa Adélia & 700 & \\
\hline A11 & Tupã & 180 & \\
\hline \multicolumn{2}{|c|}{ Total } & $\mathbf{4 9 5 0}$ & $\mathbf{4 5 0}$ \\
\hline
\end{tabular}

Quadro 6 - Volume de açúcar transportado pelo modal ferroviário, em mil toneladas, cenário 2

Fonte: resultados da pesquisa

Concluindo, o cenário 2 apresentou o relaxamento da restrição de número de terminais possíveis por município, que permitiu o aumento do número de armazéns e da capacidade instalada e levou à queda do custo total de transporte e armazenagem. Neste cenário, houve aumento da participação da ferrovia no transporte de açúcar para os portos de Santos e Paranaguá. 


\subsection{Cenário 3}

O cenário 3 não considerou custos de armazenagem, ou seja, todos os custos operacionais dos terminais foram zerados e impôs-se o estabelecimento de apenas um terminal por município. Essa suposição faz sentido num contexto de propriedade privada do armazém. Se um trader, por exemplo, constrói um armazém, por mais que contabilmente ele incorra em custos, na prática, a operação do terminal não gerará desembolsos adicionais. Esta é uma suposição forte, mas a não construção de um armazém neste contexto significaria a falta de demanda por armazenagem na região.

O custo logístico total mínimo incorrido neste modelo foi de R\$ 492.755.090,00, menor que os anteriores por não contemplar custos operacionais dos armazéns. Os fluxos e tamanhos ótimos obtidos estão expressos nos Quadros 7 e 8 e os resultados do Quadro 7 foram representados no mapa da Figura 36. A capacidade total instalada foi de 5,15 milhões de toneladas e observou-se uma capacidade ociosa de cerca de 350 mil toneladas. 


\begin{tabular}{|c|c|c|c|c|c|c|c|c|c|c|c|c|c|c|c|c|}
\hline \multirow{3}{*}{ Ui } & \multirow{3}{*}{ Usina } & \multirow{3}{*}{ Município } & \multicolumn{11}{|c|}{ Ponta Rodoviária } & \multicolumn{2}{|c|}{ Rodov. Direto } & \multirow{3}{*}{$\begin{array}{l}\text { Total } \\
\text { (mil t) }\end{array}$} \\
\hline & & & A1 & A2 & A3 & A4 & A5 & A6 & \begin{tabular}{|l|} 
A7 \\
\end{tabular} & A8 & A9 & A10 & A11 & \multirow[b]{2}{*}{ Santos } & \multirow{2}{*}{$\begin{array}{c}\text { Parana } \\
\text { guá }\end{array}$} & \\
\hline & & & $\begin{array}{l}\text { Araçat } \\
\text { uba }\end{array}$ & Arara & $\begin{array}{l}\text { Barret } \\
\text { os }\end{array}$ & Bauru & $\begin{array}{l}\text { Boitu } \\
\text { va }\end{array}$ & $\begin{array}{l}\text { Fernand } \\
\text { oppolis }\end{array}$ & $\begin{array}{l}\text { Palmi } \\
\text { tal }\end{array}$ & $\begin{array}{l}\text { Pradó } \\
\text { polis }\end{array}$ & $\begin{array}{l}\text { Ribeirão } \\
\text { Preto }\end{array}$ & $\begin{array}{l}\text { Santa } \\
\text { Adélia }\end{array}$ & Tupã & & & \\
\hline $\mathrm{U} 2$ & Albertina & Sertãozinho & & 11 & & & & & & & 79 & & & & & 90 \\
\hline U3 & Alcoazul & Araçatuba & 26 & & & & & & & & & & & & & 26 \\
\hline U5 & Alcomira & Mirandópolis & 12 & & & & & & & & & & & & & 12 \\
\hline U6 & Alta Mogiana & São Joaquim da Barra & & & & & & & & & & & & 112 & & 112 \\
\hline U7 & Alto Alegre & Presidente Prudente & & & & & & & & & & & 97 & & & 97 \\
\hline U8 & Andrade & Pitangueiras & & 5 & & & & & & & & & & & & 5 \\
\hline U9 & Aralco & Sto. Antônio do Aracanguá & 57 & & & & & & & & & & & & & 57 \\
\hline U10 & Barra Grande & Lençóis Paulista & & & & 136 & & & & & & & & & & 136 \\
\hline U11 & Bazan & Pontal & & & & & & & & & & & & 7 & & 7 \\
\hline U12 & Bela Vista & Pontal & & & & & & & & & & & & 72 & & 72 \\
\hline U13 & Benálcool & Bento de Abreu & 45 & & & & & & & & & & & & & 45 \\
\hline U15 & Branco Peres & Adamantina & & & & & & & & & & & 20 & & & 20 \\
\hline U16 & Campestre & Penápolis & & & & & & & & & & & 34 & & & 34 \\
\hline $\mathrm{U} 17$ & Catanduva & Ariranha & & & & & & & & & & 6 & & & & 6 \\
\hline U19 & Central Paulista & Jaú & & & & 40 & & & & & & & & & & 40 \\
\hline $\mathrm{U} 20$ & Centrálcool & Lucélia & & & & & & & & & & & 41 & & & 41 \\
\hline $\mathrm{U} 21$ & Cerradinho & Catanduva & & & & & & & & & & 107 & & & & 107 \\
\hline U22 & Clealco & Clementina & & & & & & & & & & & 71 & & & 71 \\
\hline $\mathrm{U} 23$ & Cocal & Paraguaçu Paulista & & & & & & & 127 & & & & & & & 127 \\
\hline U24 & Colombo & Ariranha & & & & & & & & & & 167 & & & & 167 \\
\hline $\mathrm{U} 25$ & Colorado & Guaíra & & & 166 & & & & & & & & & 29 & & 195 \\
\hline $\mathrm{U} 26$ & Corona & Guariba & & & & & & & & 280 & & & & & & 280 \\
\hline U27 & Costa Pinto & Piracaba & & & & & & & & & & & & 216 & & 216 \\
\hline $\mathrm{U} 28$ & Da Barra & Barra Bonita & & & & 126 & 198 & & & & & & & & & 324 \\
\hline U29 & Da Pedra & Serrana & & & & & & & & & & & & 116 & & 116 \\
\hline $\mathrm{U} 30$ & Da Serra & Ibaté & & & & & & & & & & & & 120 & & 120 \\
\hline U31 & Dacal & Parapuã & & & & & & & & & & & 12 & & & 12 \\
\hline U33 & DC & Dois Córregos & & & & & & & & & & & & 96 & & 96 \\
\hline U36 & Destivale & Araçatuba & 15 & & & & & & & & & & & & & 15 \\
\hline $\mathrm{U} 37$ & Diamante & Jaú & & & & & 46 & & & & & & & 74 & & 120 \\
\hline U38 & Diana & Avanhadava & & & & & & & & & & & 22 & & & 22 \\
\hline U39 & Equipav & Promissão & 106 & & & & & & & & & & & & & 106 \\
\hline $\mathrm{U} 40$ & Ester & Cosmópolis & & & & & & & & & & & & 63 & & 63 \\
\hline U41 & Floralco & Flórida Paulista & & & & & & & & & & & 36 & & & 36 \\
\hline $\mathrm{U} 42$ & Furlan & Santa Barbara D'Oeste & & & & & & & & & & & & 4 & & 4 \\
\hline $\mathrm{U} 43$ & Galo Bravo & Ribeirão Preto & & & & & & & & & 50 & & & & & 50 \\
\hline U46 & Guaíra & Guaíra & & & & & & & & & & & & 99 & & 99 \\
\hline U47 & Guarani (Cruz Alta) & Olímpia & & & 108 & & & & & & & & & & & 108 \\
\hline U48 & Guarani (Severínia) & Severínia & & & 153 & & & & & & & & & & & 153 \\
\hline $\mathrm{U} 50$ & Ibirá & Santa Rosa do Viterbo & & & & & & & & & & & & 53 & & 53 \\
\hline U51 & Ipaussu & Ipauçu & & & & & & & & & & & & & 133 & 133 \\
\hline U52 & Ipiranga (Matriz) & Descalvado & & & & & & & & & & & & 36 & & 36 \\
\hline U53 & Iracema & Iracemópolis & & & & & & & & & & & & 98 & & 98 \\
\hline U54 & Jardest & Jardinópolis & & & & & & & & & 38 & & & & & 38 \\
\hline
\end{tabular}

Quadro 7 - Volume de açúcar transportado pelo modal rodoviário, em mil toneladas, cenário 3 


\begin{tabular}{|c|c|c|c|c|c|c|c|c|c|c|c|c|c|c|c|c|}
\hline \multirow{3}{*}{ Ui } & \multirow{3}{*}{ Usina } & \multirow{3}{*}{ Município } & \multicolumn{11}{|c|}{ Ponta Rodoviária } & \multicolumn{2}{|c|}{ Rodov. Direto } & \multirow{3}{*}{$\begin{array}{l}\text { Total } \\
\text { (mil t) }\end{array}$} \\
\hline & & & A1 & A2 & A3 & A4 & A5 & A6 & A7 & A8 & A9 & A10 & A11 & \multirow[b]{2}{*}{ Santos } & \multirow{2}{*}{$\begin{array}{c}\text { Paranag } \\
\text { uá }\end{array}$} & \\
\hline & & & $\begin{array}{l}\text { Araçat } \\
\text { uba }\end{array}$ & $\begin{array}{l}\text { Araraq } \\
\text { uara }\end{array}$ & $\begin{array}{l}\text { Barret } \\
\text { os }\end{array}$ & Bauru & \begin{tabular}{|l|} 
Boituv \\
a
\end{tabular} & $\begin{array}{l}\text { Fernand } \\
\text { ópolis }\end{array}$ & \begin{tabular}{|l|} 
Palmit \\
al
\end{tabular} & $\begin{array}{l}\text { Pradó } \\
\text { polis }\end{array}$ & $\begin{array}{l}\text { Ribeirão } \\
\text { Preto }\end{array}$ & $\begin{array}{l}\text { Santa } \\
\text { Adélia }\end{array}$ & Tupã & & & \\
\hline U57 & Mandu & Guaíra & & & 73 & & & & & & & & & & & 73 \\
\hline U58 & Maracaí & Maracaí & & & & & & & 6 & & & & & & & 6 \\
\hline U59 & Maringá & Araraquara & & 3 & & & & & & & & & & & & 3 \\
\hline U60 & MB & Morro Agudo & & & & & & & & & & & & 96 & & 96 \\
\hline U62 & Moreno & Monte Aprazível & 31 & & & & & & & & & & & & & 31 \\
\hline U63 & Moreno & Luís Antônio & & & & & & & & & & & & 116 & & 116 \\
\hline U64 & Nardini & Vista Alegre do Alto & & & & & & & & & & 71 & & & & 71 \\
\hline U65 & Nossa Senhora de Aparecid & Pontal & & & & & & & & & & & & 129 & & 129 \\
\hline U66 & Nova América & Tarumã & & & & & & & 239 & & & & & & & 239 \\
\hline U68 & Parálcool & Paraguaçu Paulista & & & & & & & 2 & & & & & & & 2 \\
\hline $\mathrm{U} 70$ & Petribú Paulista & Sebastianópolis do Sul & & & & & & 42 & & & & & & & & 42 \\
\hline U71 & Pioneiros & Sud Menucci & 34 & & & & & & & & & & & & & 34 \\
\hline $\mathrm{U} 72$ & Pitangueiras & Pitangueiras & & 40 & & & & & & & & & & 17 & & 57 \\
\hline $\mathrm{U74}$ & Quatá & Quatá & & & & & & & 28 & & & & 31 & & & 59 \\
\hline U75 & Rafard & Rafard & & & & & & & & & & & & 144 & & 144 \\
\hline U76 & Santa Adélia & Jaboticabal & & 87 & & & & & & & & & & & & 87 \\
\hline U77 & Santa Cândida & Bocaina & & & & 93 & & & & & & & & & & 93 \\
\hline U78 & Santa Cruz & Américo Brasiliense & & 105 & & & & & & & & & & & & 105 \\
\hline U79 & Santa Elisa & Sertãozinho & & & & & & & & & 288 & & & & & 288 \\
\hline U80 & Santa Fé & Nova Europa & & & & 65 & & & & & & & & & & 65 \\
\hline U81 & Santa Helena & Rio das Pedras & & & & & 96 & & & & & & & & & 96 \\
\hline U83 & Santa Isabel & Novo Horionte & & & & & & & & & & 65 & & 65 & & 130 \\
\hline U84 & Santa Luiza & Motuca & & 60 & & & & & & & & & & & & 60 \\
\hline U85 & Santa Maria & Cerquilho & & & & & 27 & & & & & & & & & 27 \\
\hline U86 & Santa Rita & Santa Rita do Passa Quatro & & & & & & & & & & & & 3 & & 3 \\
\hline U87 & Snta Rosa (Boituva) & Boituva & & & & & 13 & & & & & & & & & 13 \\
\hline U88 & Santo Antônio (USA) & Sertãozinho & & 3 & & & & & & & & & & & & 3 \\
\hline U89 & São Carlos & Jaboticabal & & 78 & & & & & & & & & & & & 78 \\
\hline U90 & São Domingos & Catanduva & & & & & & & & & & 84 & & & & 84 \\
\hline U91 & São Francisco (UFRA) & Sertãozinho & & & & & & & & & 45 & & & & & 45 \\
\hline U92 & São José & Rio das Pedras & & & & & 45 & & & & & & & & & 45 \\
\hline U93 & São José (ZL) & Macatuba & & & & 40 & & & & & & & & & & 40 \\
\hline U95 & São Manuel & São Manuel & & & & & 75 & & & & & & & & & 75 \\
\hline U96 & São Martinho & Pradópolis & & 26 & & & & & & 220 & & & & & & 246 \\
\hline U98 & Unialco & Guararapes & 87 & & & & & & & & & & & & & 87 \\
\hline U99 & Univalem & Valparaíso & 87 & & & & & & & & & & & & & 87 \\
\hline U100 & Vale do Rosário & Orlândia & & & & & & & & & & & & 212 & & 212 \\
\hline U101 & Virálcool & Pitagueiras & & & & & & & & & & & & 82 & & 82 \\
\hline U103 & Zanin & Araraquara & & 82 & & & & & & & & & & & & 82 \\
\hline \multicolumn{3}{|c|}{ TOTAL } & 500 & 500 & 500 & 500 & 500 & 42 & 402 & 500 & 500 & 500 & 364 & \begin{tabular}{|l|}
2059 \\
\end{tabular} & 133 & 7000 \\
\hline
\end{tabular}

Quadro 7 - Volume de açúcar transportado pelo modal rodoviário, em mil toneladas, cenário 3

Fonte: resultados da pesquisa 


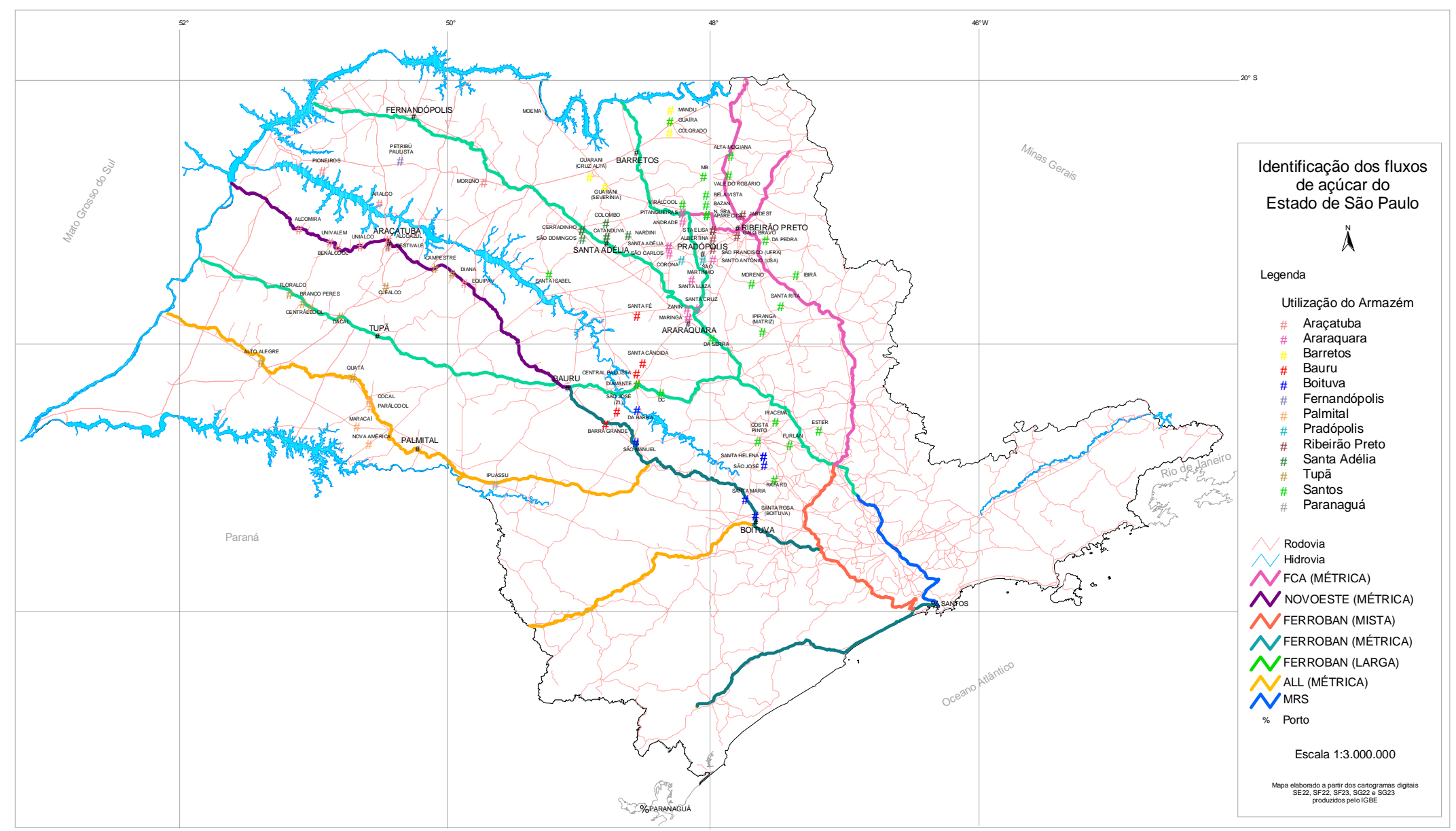

Figura 36 - Configuração dos fluxos ótimos de açúcar - CENÁRIO 3 


\begin{tabular}{|l|l|c|c|}
\hline \multirow{2}{*}{ Ai } & \multirow{2}{*}{ Município } & T5 & T10 \\
\cline { 3 - 4 } & & $150 \mathrm{mil} \mathrm{t}$ & $500 \mathrm{mil} \mathrm{t}$ \\
\hline A1 & Araçatuba & & 1 \\
\hline A2 & Araraquara & & 1 \\
\hline A3 & Barretos & & 1 \\
\hline A4 & Bauru & & 1 \\
\hline A5 & Boituva & & 1 \\
\hline A6 & Fernandópolis & 1 & \\
\hline A7 & Palmital & & 1 \\
\hline A8 & Pradópolis & & 1 \\
\hline A9 & Ribeirão Preto & & 1 \\
\hline A10 & Santa Adélia & & 1 \\
\hline A11 & Tupã & & 1 \\
\hline
\end{tabular}

Quadro 8 - Número e tamanho de armazéns instalados, cenário 3

Fonte: resultados da pesquisa

O resultado do modelo acusou o estabelecimento de terminais em todos os municípios considerados. Apenas o terminal de Fernandópolis não teria capacidade máxima, indicando a escassez de açúcar nesta região. Os terminais de Fernandópolis, Palmital e Tupã operam com ociosidade. Quanto aos dois últimos, além de estarem numa região onde a produção não é muito alta, suas áreas de influência se sobrepõem e a oferta das usinas se dividiu entre os dois terminais.

O Quadro 9 mostra os fluxos ferroviários determinados neste modelo. O volume total que passa pelos terminais, como já era esperado, é maior que no cenário 1, pois a redução de custos permite que a alternativa intermodal seja interessante para um número maior de usinas. O market share da ferrovia em Santos neste cenário alcançou aproximadamente $70 \%$ do volume recebido pelo porto. Entretanto, o aumento do volume por Paranaguá em relação ao primeiro cenário não é significativo, indicando que a redução de custos na armazenagem não afeta tanto a competitividade do transporte rodoviário na região. 


\begin{tabular}{|l|l|c|c|}
\hline \multirow{2}{*}{ Ai } & \multirow{2}{*}{ Município } & P1 & P2 \\
\cline { 3 - 4 } & & Santos & Paranaguá \\
\hline A1 & Araçatuba & 500 & \\
\hline A2 & Araraquara & 500 & \\
\hline A3 & Barretos & 500 & \\
\hline A4 & Bauru & 500 & \\
\hline A5 & Boituva & 500 & \\
\hline A6 & Fernandópolis & 42 & \\
\hline A7 & Palmital & & 402 \\
\hline A8 & Pradópolis & 500 & \\
\hline A9 & Ribeirão Preto & 500 & \\
\hline A10 & Santa Adélia & 500 & \\
\hline A11 & Tupã & 364 & \\
\hline \multicolumn{1}{|c|}{ Total } & & $\mathbf{4 4 0 6}$ & $\mathbf{4 0 2}$ \\
\hline
\end{tabular}

Quadro 9 - Volume de açúcar transportado pelo modal ferroviário, em mil toneladas, cenário 3

Fonte: resultados da pesquisa

Este mesmo modelo foi processado com permissão para instalação de 2 armazéns por município. Obteve-se o menor custo logístico, R\$ 473.421.800,00, e observou-se a instalação de dois grandes terminais (um de 500 e outro de 400 mil toneladas) em Araraquara, Barretos, Bauru, Pradópolis, Ribeirão Preto e Santa Adélia. Dois terminais (um de 500 e outro de 250 mil toneladas) seriam instalados em Araçatuba e Palmital, dois em Boituva (um de 500 e outro de 200 mil toneladas), um de 200 mil toneladas em Tupã e nenhum em Fernandópolis. Ou seja, haveria uma capacidade total de armazenagem de 7,8 milhões de toneladas, das quais 6,65 milhões seriam utilizadas. Observaria-se, portanto, uma capacidade ociosa de mais de 1 milhão de toneladas.

Este cenário permitiria que toda a produção destinada à exportação fosse transportada por ferrovia; porém, apesar disso, 354 mil toneladas seguiram em direção ao porto por rodovia. Para estas usinas, mesmo que não haja custos para armazenagem, ainda assim a alternativa intermodal não é competitiva em relação à alternativa 
rodoviária direta. São elas: Ipaussu (com destino a Paranaguá), Ester, Furlan, Ibirá, Iracema e Santa Rita.

\subsection{Cenário 4}

O cenário 4 respeita as mesmas restrições do primeiro, porém, aumenta em $10 \%$ o custo do transporte ferroviário. O intuito é de tentar observar o impacto do aumento relativo dos custos ferroviários na alocação ótima de terminais no estado de São Paulo.

O custo logístico total mínimo incorrido neste modelo foi de R\$ 538.041.910,00, o maior dos quatro cenários. A capacidade total instalada foi de 3,68 milhões de toneladas, que foram plenamente utilizadas. O Quadro 10 mostra os fluxos rodoviários ótimos de açúcar que implicam o custo logístico mínimo, dadas as restrições do modelo. A Figura 37 mostra, geograficamente, os resultados do Quadro 10. 


\begin{tabular}{|c|c|c|c|c|c|c|c|c|c|c|c|c|c|c|c|c|}
\hline \multirow{3}{*}{ Ui } & \multirow{3}{*}{ Usina } & \multirow{3}{*}{ Município } & \multicolumn{11}{|c|}{ Ponta Rodoviária } & \multicolumn{2}{|c|}{$\begin{array}{l}\text { Rodov. Direto } \\
\end{array}$} & \multirow{3}{*}{$\begin{array}{c}\text { Total } \\
\text { (mil t) }\end{array}$} \\
\hline & & & A1 & A2 & A3 & A4 & A5 & \begin{tabular}{|l|} 
A6 \\
\end{tabular} & \begin{tabular}{|l|} 
A7 \\
\end{tabular} & A8 & A9 & A10 & A11 & \multirow[b]{2}{*}{ Santos } & \multirow[b]{2}{*}{$\begin{array}{c}\text { Parana } \\
\text { guá }\end{array}$} & \\
\hline & & & \begin{tabular}{|l|} 
Araça \\
tuba
\end{tabular} & $\begin{array}{l}\text { Arara } \\
\text { quara }\end{array}$ & \begin{tabular}{|l} 
Barret \\
os
\end{tabular} & Bauru & \begin{tabular}{|l} 
Boitu \\
va
\end{tabular} & \begin{tabular}{|l|} 
Fernand \\
ópolis
\end{tabular} & $\begin{array}{l}\text { Palmi } \\
\text { tal }\end{array}$ & $\begin{array}{l}\begin{array}{l}\text { Pradó } \\
\text { polis }\end{array} \\
\end{array}$ & $\begin{array}{l}\text { Ribeirão } \\
\text { Preto }\end{array}$ & $\begin{array}{l}\text { Santa } \\
\text { Adélia }\end{array}$ & Tupã & & & \\
\hline $\mathrm{U} 2$ & Albertina & Sertãozinho & & & & & & & & & 90 & & & & & 90 \\
\hline U3 & Alcoazul & Araçatuba & 26 & & & & & & & & & & & & & 26 \\
\hline U5 & Alcomira & Mirandópolis & 12 & & & & & & & & & & & & & 12 \\
\hline $\mathrm{U} 6$ & Alta Mogiana & São Joaquim da Barra & & & & & & & & & & & & 112 & & 112 \\
\hline U7 & Alto Alegre & Presidente Prudente & & & & & & & & & & & 97 & & & 97 \\
\hline U8 & Andrade & Pitangueiras & & & & & & & & & & & & 5 & & 5 \\
\hline U9 & Aralco & Sto. Antônio do Aracanguá & 57 & & & & & & & & & & & & & 57 \\
\hline U10 & Barra Grande & Lençóis Paulista & & & & & & & & & & & & 136 & & 136 \\
\hline U11 & Bazan & Pontal & & & & & & & & & & & & 7 & & 7 \\
\hline U12 & Bela Vista & Pontal & & & & & & & & & & & & 72 & & 72 \\
\hline U13 & Benálcool & Bento de Abreu & 45 & & & & & & & & & & & & & 45 \\
\hline U15 & Branco Peres & Adamantina & & & & & & & & & & & 20 & & & 20 \\
\hline U16 & Campestre & Penápolis & 34 & & & & & & & & & & & & & 34 \\
\hline U17 & Catanduva & Ariranha & & & & & & & & & & 6 & & & & 6 \\
\hline $\mathrm{U} 18$ & CBA (antiga Sanagro $\mathrm{S}$ & Icém & & & 23 & & & & & & & & & & & 23 \\
\hline U19 & Central Paulista & Jaú & & & & & & & & & & & & 40 & & 40 \\
\hline $\mathrm{U} 20$ & Centrálcool & Lucélia & & & & & & & & & & & 41 & & & 41 \\
\hline $\mathrm{U} 21$ & Cerradinho & Catanduva & & & & & & & & & & 107 & & & & 107 \\
\hline $\mathrm{U} 22$ & Clealco & Clementina & 60 & & & & & & & & & & 11 & & & 71 \\
\hline $\mathrm{U} 23$ & Cocal & Paraguaçu Paulista & & & & & & & 127 & & & & & & & 127 \\
\hline U24 & Colombo & Ariranha & & & & & & & & & & 167 & & & & 167 \\
\hline $\mathrm{U} 25$ & Colorado & Guaíra & & & 117 & & & & & & & & & 78 & & 195 \\
\hline $\mathrm{U} 26$ & Corona & Guariba & & & & & & & & 254 & & & & 26 & & 280 \\
\hline U27 & Costa Pinto & Piracaba & & & & & & & & & & & & 216 & & 216 \\
\hline $\mathrm{U} 28$ & Da Barra & Barra Bonita & & & & & & & & & & & & 324 & & 324 \\
\hline U29 & Da Pedra & Serrana & & & & & & & & & & & & 116 & & 116 \\
\hline U30 & Da Serra & Ibaté & & & & & & & & & & & & 120 & & 120 \\
\hline U31 & Dacal & Parapuã & & & & & & & & & & & 12 & & & 12 \\
\hline U33 & DC & Dois Córregos & & & & & & & & & & & & 96 & & 96 \\
\hline U36 & Destivale & Araçatuba & 15 & & & & & & & & & & & & & 15 \\
\hline U37 & Diamante & Jaú & & & & & & & & & & & & 120 & & 120 \\
\hline U38 & Diana & Avanhadava & & & & & & & & & & & & 22 & & 22 \\
\hline U39 & Equipav & Promissão & 1 & & & & & & & & & & & 105 & & 106 \\
\hline $\mathrm{U} 40$ & Ester & Cosmópolis & & & & & & & & & & & & 63 & & 63 \\
\hline $\mathrm{U} 41$ & Floralco & Flórida Paulista & & & & & & & & & & & 36 & & & 36 \\
\hline $\mathrm{U} 42$ & Furlan & Santa Barbara D'Oeste & & & & & & & & & & & & 4 & & 4 \\
\hline $\mathrm{U} 43$ & Galo Bravo & Ribeirão Preto & & & & & & & & & 36 & & & 14 & & 50 \\
\hline $\mathrm{U} 46$ & Guaíra & Guaíra & & & 99 & & & & & & & & & & & 99 \\
\hline $\mathrm{U} 47$ & Guarani (Cruz Alta) & Olímpia & & & 108 & & & & & & & & & & & 108 \\
\hline $\mathrm{U} 48$ & Guarani (Severínia) & Severínia & & & 153 & & & & & & & & & & & 153 \\
\hline U50 & Ibirá & Santa Rosa do Viterbo & & & & & & & & & & & & 53 & & 53 \\
\hline U51 & Ipaussu & Ipauçu & & & & & & & & & & & & & 133 & 133 \\
\hline U52 & Ipiranga (Matriz) & Descalvado & & & & & & & & & & & & 36 & & \\
\hline U53 & Iracema & Iracemópolis & & & & & & & & & & & & 98 & & 98 \\
\hline U54 & Jardest & Jardinópolis & & & & & & & & & 38 & & & & & 38 \\
\hline
\end{tabular}

Quadro 10 - Volume de açúcar transportado pelo modal rodoviário, em mil toneladas, cenário 4 


\begin{tabular}{|c|c|c|c|c|c|c|c|c|c|c|c|c|c|c|c|c|}
\hline \multirow{3}{*}{ Ui } & \multirow{3}{*}{ Usina } & \multirow{3}{*}{ Município } & \multicolumn{11}{|c|}{ Ponta Rodoviária } & \multicolumn{2}{|c|}{ Rodov. Direto } & \multirow{3}{*}{$\begin{array}{l}\text { Total } \\
\text { (mil t) }\end{array}$} \\
\hline & & & A1 & A2 & A3 & A4 & A5 & A6 & A7 & A8 & A9 & A10 & A11 & \multirow[b]{2}{*}{ Santos } & \multirow{2}{*}{$\begin{array}{c}\text { Paranag } \\
\text { uá }\end{array}$} & \\
\hline & & & \begin{tabular}{|l|} 
Araçatu \\
ba
\end{tabular} & $\begin{array}{l}\text { Araraqu } \\
\text { ara }\end{array}$ & \begin{tabular}{|l} 
Barreto \\
s
\end{tabular} & Bauru & Boituva & \begin{tabular}{|l|} 
Fernand \\
ópolis \\
\end{tabular} & \begin{tabular}{|l|} 
Palmit \\
al
\end{tabular} & \begin{tabular}{|l|} 
Pradóp \\
olis
\end{tabular} & \begin{tabular}{|l} 
Ribeirão \\
Preto
\end{tabular} & \begin{tabular}{|l|} 
Santa \\
Adélia \\
\end{tabular} & Tupã & & & \\
\hline U57 & Mandu & Guaíra & & & & & & & & & & & & 73 & & 73 \\
\hline U58 & Maracaí & Maracaí & & & & & & & 6 & & & & & & & 6 \\
\hline U59 & Maringá & Araraquara & & 3 & & & & & & & & & & & & 3 \\
\hline U60 & MB & Morro Agudo & & & & & & & & & & & & 96 & & 96 \\
\hline U62 & Moreno & Monte Aprazível & & & & & & & & & & & & & 31 & 31 \\
\hline U63 & Moreno & Luís Antônio & & & & & & & & & & & & 116 & & 116 \\
\hline U64 & Nardini & Vista Alegre do Alto & & & & & & & & & & 71 & & & & 71 \\
\hline U65 & Nossa Senhora de Aparecida & Pontal & & & & & & & & & & & & 129 & & 129 \\
\hline U66 & Nova América & Tarumã & & & & & & & 239 & & & & & & & 239 \\
\hline U68 & Parálcool & Paraguaçu Paulista & & & & & & & 2 & & & & & & & 2 \\
\hline $\mathrm{U} 70$ & Petribú Paulista & Sebastianópolis do Sul & 42 & & & & & & & & & & & & & 42 \\
\hline U71 & Pioneiros & Sud Menucci & 34 & & & & & & & & & & & & & 34 \\
\hline U72 & Pitangueiras & Pitangueiras & & & & & & & & & & & & 57 & & 57 \\
\hline $\mathrm{U} 74$ & Quatá & Quatá & & & & & & & 26 & & & & 33 & & & 59 \\
\hline U75 & Rafard & Rafard & & & & & & & & & & & & 144 & & 144 \\
\hline $\mathrm{U} 76$ & Santa Adélia & Jaboticabal & & 87 & & & & & & & & & & & & 87 \\
\hline $\mathrm{U} 77$ & Santa Cândida & Bocaina & & 20 & & & & & & & & & & 73 & & 93 \\
\hline U78 & Santa Cruz & Américo Brasiliense & & 105 & & & & & & & & & & & & 105 \\
\hline U79 & Santa Elisa & Sertãozinho & & & & & & & & & 288 & & & & & 288 \\
\hline U80 & Santa Fé & Nova Europa & & 65 & & & & & & & & & & & & 65 \\
\hline U81 & Santa Helena & Rio das Pedras & & & & & & & & & & & & 96 & & 96 \\
\hline U83 & Santa Isabel & Novo Horionte & & & & & & & & & & 7 & & & 36 & 43 \\
\hline U84 & Santa Luiza & Motuca & & 60 & & & & & & & & & & & & 60 \\
\hline U85 & Santa Maria & Cerquilho & & & & & & & & & & & & 27 & & 27 \\
\hline U86 & Santa Rita & Santa Rita do Passa Quatro & & & & & & & & & & & & 3 & & 3 \\
\hline U87 & Snta Rosa (Boituva) & Boituva & & & & & & & & & & & & 13 & & 13 \\
\hline U88 & Santo Antônio (USA) & Sertãozinho & & & & & & & & & 3 & & & & & $\overline{3}$ \\
\hline U89 & São Carlos & Jaboticabal & & 78 & & & & & & & & & & & & 78 \\
\hline U90 & São Domingos & Catanduva & & & & & & & & & & 84 & & & & 84 \\
\hline U91 & São Francisco (UFRA) & Sertãozinho & & & & & & & & & 45 & & & & & 45 \\
\hline U92 & São José & Rio das Pedras & & & & & & & & & & & & 45 & & 45 \\
\hline U93 & São José (ZL) & Macatuba & & & & 30 & & & & & & & & 10 & & 40 \\
\hline U94 & São José da Estiva & Novo Horizonte & & & & & & & & & & 58 & & 6 & & 64 \\
\hline U95 & São Manuel & São Manuel & & & & & & & & & & & & 75 & & 75 \\
\hline U96 & São Martinho & Pradópolis & & & & & & & & 246 & & & & & & 246 \\
\hline U98 & Unialco & Guararapes & 87 & & & & & & & & & & & & & 87 \\
\hline U99 & Univalem & Valparaíso & 87 & & & & & & & & & & & & & 87 \\
\hline U100 & Vale do Rosário & Orlândia & & & & & & & & & & & & 212 & & 212 \\
\hline U101 & Virálcool & Pitagueiras & & & & & & & & & & & & 82 & & 82 \\
\hline U103 & Zanin & Araraquara & & 82 & & & & & & & & & & & & 82 \\
\hline & Total & & 500 & 500 & 500 & 30 & 0 & 0 & 400 & 500 & 500 & 500 & 250 & 3120 & 200 & 7000 \\
\hline
\end{tabular}

Quadro 10 - Volume de açúcar transportado pelo modal rodoviário, em mil toneladas, cenário 4

Fonte: resultados da pesquisa 


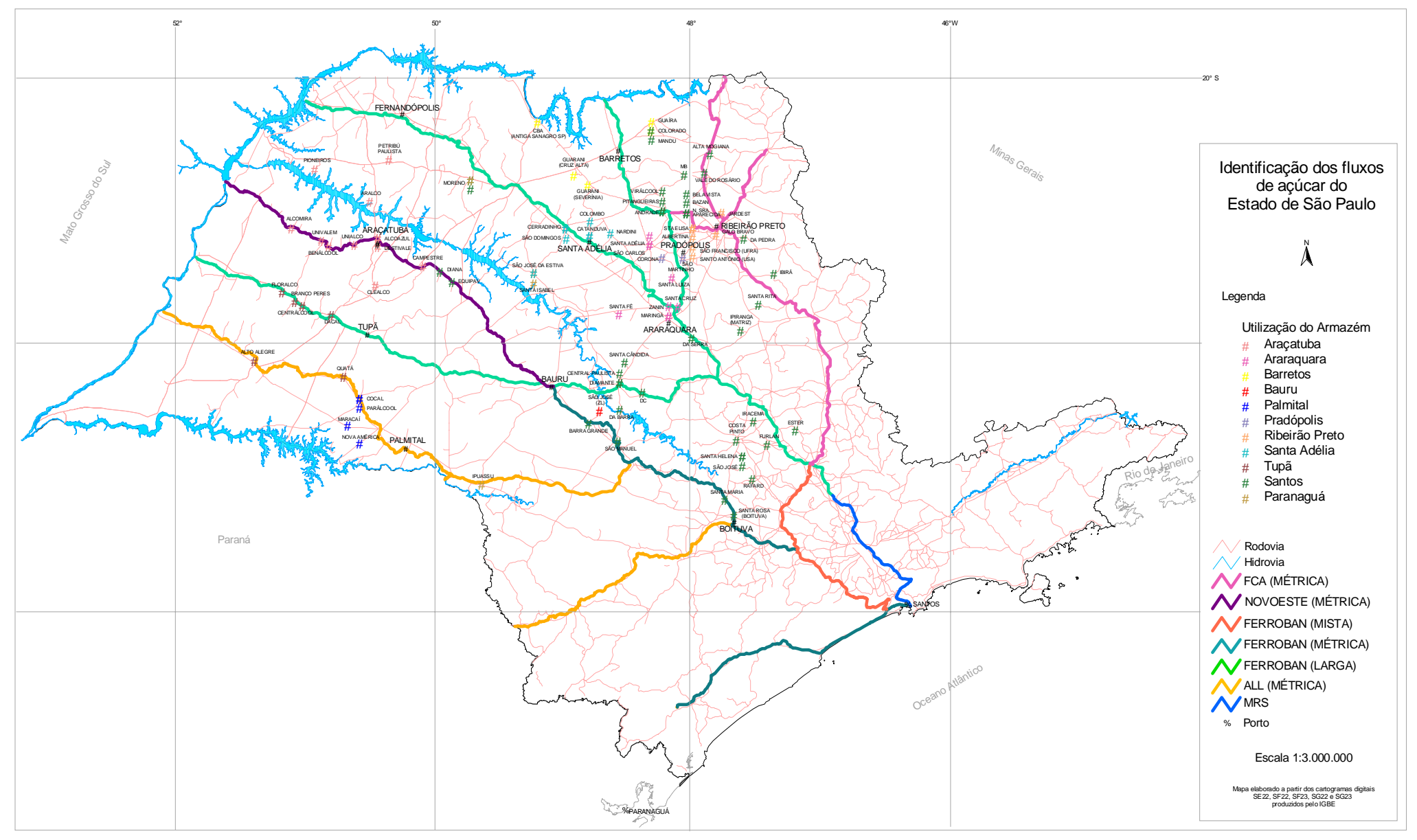

Figura 37 - Configuração dos fluxos ótimos de açúcar - CENÁRIO 4 
O resultado das capacidades e alocações ótimas de terminais no cenário 4, representados no Quadro 11, permite uma comparação interessante com o Quadro 2. Pode-se concluir que o aumento de $10 \%$ no frete ferroviário não afeta o tamanho ótimo dos terminais de Araçatuba, Araraquara, Barretos, Pradópolis, Ribeirão Preto (estes continuam com 500 mil toneladas) e o de Palmital (que permanece com 400 mil toneladas de capacidade). Estas regiões de alta produção realmente parecem demandar armazéns de grandes capacidades, pois se mostraram totalmente viáveis mesmo com um aumento do frete ferroviário em relação ao rodoviário.

O tamanho ótimo do terminal de Tupã passou a ser um pouco menor do que no cenário 1. Já os terminais de Bauru e Fernandópolis mostraram-se bastante sensíveis à variação no frete ferroviário. Para o agente investidor, seja ele privado ou público, isso pode caracterizar um risco adicional.

\begin{tabular}{|l|l|c|c|c|c|}
\hline \multirow{2}{*}{ Ai } & \multirow{2}{*}{ Município } & T1 & T7 & T9 & T10 \\
\cline { 3 - 6 } & & $30 \mathrm{mil} \mathrm{t}$ & $250 \mathrm{mil} \mathrm{t}$ & $400 \mathrm{mil} \mathrm{t}$ & $500 \mathrm{mil} \mathrm{t}$ \\
\hline A1 & Araçatuba & & & & 1 \\
\hline A2 & Araraquara & & & & 1 \\
\hline A3 & Barretos & & & & 1 \\
\hline A4 & Bauru & 1 & & & \\
\hline A7 & Palmital & & & 1 & \\
\hline A8 & Pradópolis & & & & 1 \\
\hline A9 & Ribeirão Preto & & & & 1 \\
\hline A10 & Santa Adélia & & & & 1 \\
\hline A11 & Tupã & & 1 & & \\
\hline
\end{tabular}

Quadro 11 - Número e tamanho de armazéns instalados, cenário 4 Fonte: resultados da pesquisa

O volume de açúcar transportado pelo modal ferroviário no cenário 4 pode ser visto no Quadro 12. Comparando-o com o cenário 1, a quantidade de açúcar recebido pelo Porto de Santos pela ferrovia é um pouco menor e igual para o caso do Porto de 
Paranaguá, ou seja, o aumento de frete ferroviário não afeta o volume que segue por ferrovia para Paranaguá o qual, aliás, manteve-se bastante estável em todos os cenários.

\begin{tabular}{|c|c|c|c|}
\hline \multirow{2}{*}{$\mathbf{A i}$} & \multirow{2}{*}{ Município } & P1 & $\mathbf{P 2}$ \\
\hline & & Santos & Paranaguá \\
\hline $\mathbf{A 1}$ & Araçatuba & 500 & \\
\hline A2 & Araraquara & 500 & \\
\hline A3 & Barretos & 500 & \\
\hline A4 & Bauru & 30 & \\
\hline$\overline{A 7}$ & Palmital & & 400 \\
\hline A8 & Pradópolis & 500 & \\
\hline A9 & Ribeirão Preto & 500 & \\
\hline $\mathbf{A 1 0}$ & Santa Adélia & 500 & \\
\hline A11 & Tupã & 250 & \\
\hline & Total & 3280 & 400 \\
\hline
\end{tabular}

Quadro 12 - Volume de açúcar transportado pelo modal ferroviário, em mil toneladas, cenário 4

Fonte: resultados da pesquisa

Uma última observação relevante é a explicação de usinas localizadas no mesmo município enviarem seus produtos para lugares distintos num contexto de minimização de custos logísticos. Este é o caso das usinas localizadas no município de Guaíra (Mandu, Colorado e Guaíra) para os cenários 1,3 e 4.

No cenário 1, os fluxos ótimos não utilizaram o açúcar que provém da Usina Mandu. Provavelmente, o escoamento do produto desta usina é um dos que tem maior impacto relativo no custo logístico final, dentro das condições do cenário 1 . Na situação de custo mínimo, a Usina Guaíra deve escoar a maior parte da sua produção por rodovia, diretamente para o Porto de Santos. Já a Usina Colorado, deve exportar seu açúcar utilizando o transporte intermodal que passa pelo armazém de Barretos. 
A produção total de Guaíra não é escoada pelo terminal de Barretos porque a capacidade ótima deste é preenchida com a produção das usinas Guarani (de Olímpia e Severínia), CBA e Colorado.

Apesar de a Usina CBA estar mais longe do terminal de Barretos do que a Usina Guaíra, o fluxo ótimo inclui CBA como fornecedora de Barretos e não inclui Guaíra. Estima-se que a ponta rodoviária entre Icem e Barretos custa, em média, R \$9,95 / t e entre Guaíra e Barretos, R\$ 5,24 / t. Estas variáveis, vistas individualmente, dariam indicações de que, para atingir um custo mínimo, a Usina Colorado utilizaria o terminal de Barretos ao invés da CBA. Contudo, deve-se considerar o sistema como um todo e a sua simultaneidade, para analisar as combinações de menor custo. O frete rodoviário considerado de Icem diretamente para Santos é R \$ 60,72 e o de Guaíra a Santos, R\$ 53,48. Portanto, o ganho obtido com o envio direto do açúcar de Guaíra diretamente para Santos ao invés do açúcar de Icem, mais que compensa a perda por não enviar o açúcar de Guaíra por Barretos e enviar o de Icem. Este mesmo tipo de raciocínio pode ser utilizado para os outros cenários. 


\section{CONCLUSÕES}

O Brasil é o maior produtor e exportador de açúcar do mundo, participando com cerca de $30 \%$ do mercado livre mundial. Durante 60 anos, o setor sucroalcooleiro brasileiro viveu sob a égide do Estado. Nos anos 90, entretanto, passou pelo processo de desregulamentação que trouxe novos e grandes desafios às empresas para se adequarem ao ambiente de livre mercado. Novas estratégias tiveram que ser desenvolvidas para manter a competitividade do produto no mercado internacional. Não houve consenso entre os agentes do mercado sobre as estratégias que deveriam ser adotadas para enfrentar os problemas advindos da desregulamentação e observou-se a montagem de campos organizacionais distintos. Neste contexto, a otimização da logística e o melhor planejamento da comercialização do açúcar tornaram-se elementos importantes para o setor.

Num país historicamente "rodoviarista", a privatização das ferrovias proporcionou um aumento significativo do volume transportado por esta modalidade e da confiança no setor, que havia sido perdida com os inúmeros problemas enfrentados nos últimos anos. Observou-se o aumento da participação do modal ferroviário no transporte de produtos de baixo valor agregado, como é o caso do açúcar. A logística intermodal surge então como uma alternativa ao transporte rodoviário, com significativas vantagens de custo e escala. Uma prova disso são os recentes altos investimentos, inclusive do setor sucroalcooleiro, na viabilização de alternativas multimodais visando à redução de custos e melhoria da qualidade de atendimento aos clientes. 
Para viabilização do transporte ferroviário de carga, é necessária a agregação da carga em um local, dado que o volume de carga transportado por um comboio é alto e o carregamento eficiente de vagões deve ocorrer em um único local. Visto isso, a avaliação da localização de armazéns intermodais concentradores de carga torna-se interessante.

Este trabalho teve o objetivo de analisar a distribuição espacial ótima de armazéns para movimentação de açúcar no estado de São Paulo utilizando o transporte ferroviário. $\mathrm{O}$ instrumento utilizado para esta avaliação foi um modelo matemático de programação mista que teve como objetivo a minimização de custos de transporte e armazenagem. Os resultados deste modelo indicam algumas tendências para localização e capacidade destes armazéns. Cabe destacar as limitações deste modelo, principalmente no que se refere a ofertas e demandas fixas, não consideração de economias de escala no transporte e no armazenamento e a não contemplação da variável tempo e dos custos de construção e implantação dos terminais.

O estudo desenvolvido avaliou quatro cenários. Os resultados da otimização nestes cenários estão resumidos no Quadro 13 e permitem a inferência de algumas conclusões. 


\begin{tabular}{|c|c|c|c|c|c|c|}
\hline Cenário & Custo mínimo & $\begin{array}{c}\text { Capacidade de } \\
\text { armazenagem } \\
\text { (milhões t) }\end{array}$ & $\begin{array}{c}\text { Ociosidade } \\
\text { (mil t) }\end{array}$ & $\begin{array}{c}\text { Market Share } \\
\text { Ferrovia em } \\
\text { Santos }\end{array}$ & $\begin{array}{l}\text { Quantidade de } \\
\text { armazéns }\end{array}$ & Localização dos armazéns \\
\hline 1 & $\mathrm{R} \$ 524.931 .810,00$ & 4,05 & - & $57 \%$ & 10 & $\begin{array}{l}\text { * } 500 \text { mil t: Araçatuba, Araraquara, } \\
\text { Barretos, Pradópolis, Ribeirão Preto e } \\
\text { Santa Adélia } \\
\text { * } 400 \text { mil t: Palmital } \\
\text { * } 300 \text { mil t: Bauru e Tupã } \\
\text { * } 50 \text { mil t: Fernandópolis }\end{array}$ \\
\hline 2 & $\mathrm{R} \$ 515.692 .610,00$ & 5,40 & - & $77 \%$ & 18 & $\begin{array}{l}\text { * } 500 \text { mil t: Araraquara, Barretos, } \\
\text { Pradópolis, Ribeirão Preto } \\
\text { * } 400 \text { mil t: Araçatuba, Araraquara, } \\
\text { Palmital, Pradópolis, Ribeirão Preto, Santa } \\
\text { Adélia } \\
\text { * } 300 \text { mil t: Santa Adélia } \\
\text { * } 150 \text { mil t: Araçatuba, Bauru e Tupã } \\
\text { * } 100 \text { mil t: Barretos } \\
\text { * } 70 \text { mil t: Bauru } \\
\text { * } 50 \text { mil t: Palmital } \\
\text { * } 30 \text { mil t: Tupã }\end{array}$ \\
\hline 3 & $\mathrm{R} \$ 492.755 .090,00$ & 5,15 & 315 & $69 \%$ & 11 & $\begin{array}{l}\text { * } 500 \text { mil t: Araçatuba, Araraquara, } \\
\text { Barretos, Bauru, Boituva, Palmital, } \\
\text { Pradópolis, Ribeirão Preto, Santa Adélia e } \\
\text { Tupã } \\
\text { * } 150 \text { mil t:Fernandópolis }\end{array}$ \\
\hline $3^{\prime}$ & $\mathrm{R} \$ 473.421 .800,00$ & 7,80 & 1150 & N/D & 17 & $\begin{array}{l}\text { * } 500 \text { mil t: Araçatuba, Araraquara, } \\
\text { Barretos, Bauru, Palmital, Pradópolis, } \\
\text { Ribeirão Preto e Santa Adélia } \\
\text { * } 400 \text { mil t: Araraquara, Barretos, Bauru, } \\
\text { Pradópolis, Ribeirão Preto e Santa Adélia } \\
\text { * } 250 \text { mil t: Araçatuba e Palmital } \\
\text { * } 200 \text { mil t: Tupã } \\
\end{array}$ \\
\hline 4 & $\mathrm{R} \$ 538.041 .910,00$ & 3,68 & - & $51 \%$ & 9 & $\begin{array}{l}\text { * } 500 \text { mil t: Araçatuba, Araraquara, } \\
\text { Barretos, Pradópolis, Ribeirão Preto e } \\
\text { Santa Adélia } \\
\text { * } 400 \text { mil t: Palmital } \\
\text { * } 250 \text { mil t: Tupã } \\
\text { * } 30 \text { mil t: Bauru }\end{array}$ \\
\hline
\end{tabular}

Quadro 13 - Resumo dos resultados do modelo matemático de otimização

Fonte: resultados da pesquisa

Primeiramente, pode-se destacar que a alternativa intermodal mostrou-se bastante competitiva. Em todos os casos, os resultados sugeriram a construção de terminais intermodais, variando o tamanho e a localização, dependendo dos parâmetros utilizados.

Conclui-se que há bastante espaço para aumento da participação da entrega de açúcar no Porto de Santos através da modalidade ferroviária. Atualmente, o market 
share da ferrovia neste porto é de cerca de $10 \%$, ou seja, $90 \%$ do açúcar ainda chega ao Porto de Santos por caminhão. Os resultados indicaram variações de market share entre $50 \%$ e $80 \%$. Mesmo que este patamar seja considerado alto, dá indicações de espaço para aumento da participação do transporte ferroviário no transporte de açúcar para exportação. Ressalta-se que para viabilização deste aumento é necessária a adequação do porto de tal forma que o aumento da movimentação de vagões na área portuária e nos terminais se tornem possíveis.

Além disso, o aumento da movimentação do açúcar por ferrovia também está sujeito à capacidade de atendimento da demanda por parte das empresas ferroviárias. A tentativa de sanar o problema da escassez de ativos está ocorrendo através de parcerias com clientes, mas as condições da via ainda parecem caracterizar uma questão mais grave.

É importante salientar as condições internacionais favoráveis do mercado sucroalcooleiro e a competitividade do país na produção de açúcar. Eventualmente, alterações neste mercado podem alterar a dinâmica do setor e, por conseguinte, a alocação ótima obtida neste modelo. Por exemplo, uma pressão exógena para diminuição das exportações poderia afetar os parâmetros deste modelo e, conseqüentemente, seus resultados. Entretanto, como já mencionado, os fatores locacionais são dinâmicos e podem mudar ao longo do tempo e eventuais alterações não invalidam a importância deste trabalho.

Os resultados de todos os quatro cenários indicaram o estabelecimento de grandes armazéns (com capacidades dinâmicas entre 400 e 500 toneladas) em Araraquara, Barretos, Ribeirão Preto, Pradópolis, Santa Adélia e Araçatuba. Estes municípios, com exceção de Araçatuba, estão localizados na região de maior produção e maior concentração de usinas do país. Araçatuba está localizada na área de maior expansão da cana no estado de São Paulo.

Alguns destes locais já possuem estruturas dedicadas à operação ferroviária de açúcar. São os casos de Pradópolis, sede da Usina São Martinho, de Santa Adélia, 
local escolhido pela EDF\&Man para concentrar a carga captada pela trading na região e Araçatuba, onde Sucden do Brasil, Aralco e Unialco investiram na construção de um armazém intermodal especializado em açúcar. Em Araraquara e Ribeirão Preto existem unidades do Ceagesp.

Também foi indicada, em todos os cenários, a instalação de terminais em Tupã, Bauru e Palmital, apesar de que em alguns cenários eles não aparecem como armazéns grandes, o que parece ter relação com a produção relativamente baixa dessas regiões. A alternativa logística que envolve o terminal de Palmital e o Porto de Paranaguá foi utilizada em todos os cenários, mostrando que esta pode ser uma alternativa viável. A indicação de Fernandópolis não ocorreu em alguns cenários, pois sua área de influência considerada representa uma região de baixa produção o que impediu sua viabilização.

Além disso, somente os resultados do cenário 3, que desconsidera os custos operacionais de armazenagem, indicaram a instalação de terminal em Boituva, município que está próximo ao Porto de Santos, onde a competitividade do modal rodoviário é alta. Este resultado vai de encontro à premissa de que o transporte ferroviário não é competitivo a curtas distâncias.

Concluindo, a viabilidade de instalação de armazéns parece estar bastante dependente da concentração de usinas ao redor do município considerado e suas distâncias em relação ao porto. Para regiões com alta concentração de usinas e relativamente distante dos portos (distâncias superiores a 300 quilômetros), os resultados do modelo indicam a viabilidade da construção de terminais intermodais concentradores de carga.

A minimização dos custos logísticos implica a interdependência das decisões das usinas para formulação de uma estratégia conjunta, porém, historicamente, o setor sucroalcooleiro não tem tendência de cooperação. A ferramenta aqui utilizada pode ser aplicada, por exemplo, para grupos de comercialização que objetivem a otimização do seu sistema logístico. Inclusive, poderia ser aproveitada também para balizar decisões de 
usinas desejem buscar parceiros para formação de grupos de comercialização. Além disso, a ferramenta pode ser um apoio à decisão de órgãos públicos para avaliação de viabilidade de construção de armazéns interiores.

A coordenação entre agentes do setor para instalação de armazéns no interior do país mostrou-se uma oportunidade de reduzir custos de exportação de açúcar e pode ser uma boa alternativa para evitar gargalos no porto, atualmente bastante saturados.

Ficam como sugestões para trabalhos futuros, pesquisas sobre o dimensionamento da capacidade instalada já existente em cada uma destas regiões, a possibilidade dos agentes agregarem carga em um determinado local e a comparação com os resultados deste modelo, além da consideração de uma maior área, como a região Centro-Sul, por exemplo, ao invés da limitação ao estado de São Paulo. 
ANEXOS 
ANEXO A - Principais pontos de embarque da Brasil Ferrovias 
ANEXO B - Planilhas de distância e custo de transporte

\begin{tabular}{|c|c|c|c|c|c|c|c|c|c|c|c|c|c|c|}
\hline Usina & Município & $\begin{array}{c}\text { Araçatu } \\
\text { ba }\end{array}$ & $\begin{array}{c}\text { Araraq } \\
\text { uara }\end{array}$ & $\begin{array}{c}\text { Barreto } \\
\mathrm{s}\end{array}$ & Bauru & $\begin{array}{c}\text { Boitu } \\
\text { va }\end{array}$ & $\begin{array}{l}\text { Fernand } \\
\text { ópolis }\end{array}$ & Palmital & $\begin{array}{l}\text { Pradópo } \\
\text { lis }\end{array}$ & $\begin{array}{l}\text { Ribeirão } \\
\text { Preto }\end{array}$ & $\begin{array}{l}\text { Santa } \\
\text { Adélia }\end{array}$ & $\begin{array}{c}\text { Tupã } \\
\text { (Ceages } \\
\text { p) }\end{array}$ & $\begin{array}{l}\text { Paranag } \\
\text { uá }\end{array}$ & Santos \\
\hline Agua Bonita & Tarumã & 207 & - & - & - & - & - & 50 & - & - & - & 106 & 577 & 521 \\
\hline Albertina & Sertãozinho & - & 95 & - & - & - & - & - & 38 & 24 & - & - & 738 & 390 \\
\hline Alcoazul & Araçatuba & 20 & - & - & - & - & 140 & 282 & - & - & - & 108 & 763 & 550 \\
\hline Alcoeste & Fernandópolis & 140 & - & - & - & - & 10 & - & - & - & - & 247 & 892 & 638 \\
\hline Alcomira & Mirandópolis & 90 & - & - & - & - & 211 & - & - & - & - & 157 & 836 & 610 \\
\hline Alta Mogiana & São Joaquim da Barra & - & 156 & - & - & - & - & - & 116 & 80 & - & - & 791 & 443 \\
\hline Alto Alegre & Presidente Prudente & 169 & - & - & - & - & - & 154 & - & - & - & 103 & 642 & 625 \\
\hline Andrade & Pitangueiras & - & 94 & - & - & - & - & - & 57 & 57 & 80 & - & 771 & 423 \\
\hline Aralco & Sto. Antônio do Aracanguá & 45 & - & - & - & - & 112 & - & - & - & - & 145 & 801 & 590 \\
\hline Barra Grande & Lençóis Paulista & - & 137 & - & 47 & 173 & - & - & - & - & - & - & 597 & 350 \\
\hline Bazan & Pontal & - & 114 & - & - & - & - & - & 55 & 43 & - & - & 757 & 409 \\
\hline Bela Vista & Pontal & - & 114 & - & - & - & - & - & 55 & 43 & - & - & 757 & 409 \\
\hline Benálcool & Bento de Abreu & 50 & - & - & - & - & 181 & 325 & - & - & - & 148 & 806 & 600 \\
\hline Bertolo & Pirangi & - & - & - & - & - & - & - & 80 & 115 & 22 & - & 808 & 460 \\
\hline Branco Peres & Adamantina & 120 & - & - & - & - & 246 & 193 & - & - & - & 67 & 718 & 650 \\
\hline Campestre & Penápolis & 70 & - & - & - & - & 173 & 240 & - & - & - & 84 & 721 & 515 \\
\hline Catanduva & Ariranha & - & - & - & - & - & - & - & 92 & 127 & 15 & - & 806 & 458 \\
\hline CBA (antiga Sanagro & Icém & - & - & 91 & - & - & - & - & 180 & 189 & - & - & 918 & 570 \\
\hline Central Paulista & Jaú & - & 77 & - & 59 & 201 & - & - & - & - & - & - & 625 & 346 \\
\hline Centrálcool & Lucélia & 110 & - & - & - & - & 251 & 188 & - & - & - & 62 & 715 & 600 \\
\hline Cerradinho & Catanduva & - & - & - & - & - & $\cdot$ & - & 123 & 159 & 22 & - & 810 & 462 \\
\hline Clealco & Clementina & 45 & - & - & - & - & 187 & 190 & -1 & - & - & 64 & 760 & 555 \\
\hline Cocal & Paraguaçu Paulista & 176 & - & - & - & - & - & 64 & - & - & - & 72 & 591 & 535 \\
\hline Colombo & Ariranha & - & - & - & - & - & - & - & 92 & 127 & 15 & - & 806 & 458 \\
\hline Colorado & Guaíra & - & - & 39 & - & - & - & - & 154 & 139 & - & - & 850 & 502 \\
\hline Corona & Guariba & - & - & - & - & - & - & - & 18 & 64 & 85 & - & 760 & 412 \\
\hline Costa Pinto & Piracaba & - & - & - & - & 65 & - & - & - & - & - & - & 571 & 223 \\
\hline Da Barra & Barra Bonita & - & 102 & - & 84 & 180 & - & - & - & - & - & - & 604 & 357 \\
\hline Da Pedra & Serrana & - & 106 & - & - & - & - & - & 76 & 35 & - & - & 726 & 378 \\
\hline Da Serra & Ibaté & - & 29 & - & - & - & - & - & 91 & 104 & - & - & 675 & 327 \\
\hline Dacal & Parapuã & 80 & - & - & - & - & 236 & 163 & - & - & - & 37 & 690 & 580 \\
\hline Dalsa & Monte Aprazível & 130 & - & - & - & - & 103 & - & - & - & - & 192 & 802 & 558 \\
\hline $\mathrm{DC}$ & Dois Córregos & - & 88 & - & 86 & 200 & - & - & - & - & - & - & 624 & 325 \\
\hline Della Coletta & Bariri & - & 91 & - & - & 242 & - & - & - & - & - & - & 666 & 397 \\
\hline Destil & Itajobi & - & - & - & - & - & - & - & 129 & 165 & 37 & - & 816 & 468 \\
\hline Destivale & Araçatuba & 20 & - & - & - & - & 140 & 282 & $-\quad$ & - & - & 108 & 763 & 550 \\
\hline Diamante & Jaú & - & 77 & - & - & 201 & - & - & - & - & - & - & 625 & 346 \\
\hline Diana & Avanhadava & 85 & - & - & - & - & 187 & 227 & - & - & - & 98 & 708 & 501 \\
\hline Equipav & Promissão & 82 & - & - & - & - & 205 & 214 & - & - & - & 114 & 695 & 516 \\
\hline Ester & Cosmópolis & - & - & - & - & 126 & - & - & - & - & - & - & 546 & 198 \\
\hline Floralco & Flórida Paulista & 130 & - & - & - & - & 247 & 207 & - & - & - & 81 & 734 & 630 \\
\hline Furlan & Santa Barbara D'Oeste & - & - & - & - & 77 & - & - & - & - & - & - & 551 & 203 \\
\hline Galo Bravo & Ribeirão Preto & - & 79 & - & - & - & - & - & 49 & 10 & - & - & 716 & 368 \\
\hline Gasa & Andradina & 130 & - & - & - & - & 179 & - & - & - & - & 198 & 877 & 650 \\
\hline Grizzo & Jaú & - & 77 & - & 59 & 201 & - & - & - & - & - & - & 625 & 346 \\
\hline Guaíra & Guaíra & - & - & 39 & - & - & - & - & 154 & 139 & - & - & 850 & 502 \\
\hline Guarani (Cruz Alta) & Olímpia & - & - & 50 & - & - & - & - & 131 & 140 & 76 & - & 866 & 518 \\
\hline Guarani (Severínia) & Severínia & - & - & 52 & - & - & - & - & 117 & 126 & 62 & - & 858 & 510 \\
\hline Guaricanga & Presidente Alves & - & 185 & - & - & 270 & - & - & - & - & - & - & 673 & 447 \\
\hline Ibirá & Santa Rosa do Viterbo & - & 114 & - & - & - & - & - & 92 & 66 & - & - & 683 & 335 \\
\hline Ipaussu & Ipauçu & - & - & - & - & 251 & - & - & - & - & - & - & 537 & 428 \\
\hline Ipiranga (Matriz) & Descalvado & - & 81 & - & - & - & - & - & 115 & 96 & - & - & 646 & 298 \\
\hline Iracema & Iracemópolis & - & - & - & - & 92 & - & - & - & - & - & - & 581 & 233 \\
\hline Jardest & Jardinópolis & - & 103 & - & - & - & - & - & 63 & 27 & - & - & 738 & 390 \\
\hline Londra & Itaí & - & 225 & - & 163 & 188 & - & - & $-\quad$ & - & - & - & 483 & 365 \\
\hline Malosso & Itápolis & - & 76 & - & 115 & 275 & - & - & 97 & 133 & 60 & - & 772 & 424 \\
\hline
\end{tabular}

Quadro 14 - Distâncias entre origens e destinos de rotas consideradas 


\begin{tabular}{|c|c|c|c|c|c|c|c|c|c|c|c|c|c|c|}
\hline Usina & Município & $\begin{array}{c}\text { Araçatu } \\
\text { ba }\end{array}$ & $\begin{array}{l}\text { Araraq } \\
\text { uara }\end{array}$ & $\begin{array}{c}\text { Barreto } \\
\text { s }\end{array}$ & Bauru & $\begin{array}{c}\text { Boitu } \\
\text { va }\end{array}$ & $\begin{array}{c}\text { Fernand } \\
\text { ópolis }\end{array}$ & Palmital & $\begin{array}{l}\text { Pradópo } \\
\text { lis }\end{array}$ & $\begin{array}{l}\text { Ribeirão } \\
\text { Preto }\end{array}$ & $\begin{array}{l}\text { Santa } \\
\text { Adélia }\end{array}$ & Tupã & $\begin{array}{l}\text { Paranag } \\
\text { uá }\end{array}$ & Santos \\
\hline Mandu & Guaíra & - & - & 39 & - & - & - & - & 154 & 139 & - & - & 850 & 502 \\
\hline Maracaí & Maracaí & 194 & - & - & - & - & - & 58 & - & - & - & 93 & 585 & 529 \\
\hline Maringá & Araraquara & - & 10 & - & - & - & - & - & 66 & 79 & - & - & 696 & 348 \\
\hline MB & Morro Agudo & - & 140 & - & - & - & - & - & 111 & 75 & - & - & 786 & 438 \\
\hline Moema & Orindiúva & - & - & 122 & - & - & - & - & 211 & 220 & - & - & 946 & 598 \\
\hline Moreno & Monte Aprazível & 130 & - & - & - & - & 103 & - & - & - & - & 192 & 802 & 558 \\
\hline Moreno & Luís Antônio & - & 76 & - & - & - & - & - & 54 & 49 & - & - & 681 & 333 \\
\hline Nardini & Vista Alegre do Alto & - & - & - & - & - & - & - & 72 & 107 & 29 & - & 799 & 451 \\
\hline Nossa Senhora de Ap & Pontal & - & 114 & - & - & - & - & - & 55 & 43 & - & - & 757 & 409 \\
\hline Nova América & Tarumã & 207 & - & - & - & - & - & 50 & - & - & - & 106 & 577 & 521 \\
\hline Paraíso Bioenergia & Brotas & - & 103 & - & 118 & 131 & - & - & - & - & - & - & 671 & 323 \\
\hline Parálcool & Paraguaçu Paulista & 176 & - & - & - & - & - & 64 & - & - & - & 72 & 591 & 535 \\
\hline Pederneiras & Tietê & - & - & - & - & 19 & - & - & - & - & - & - & 451 & 204 \\
\hline Petribú Paulista & Sebastianópolis do Sul & 106 & - & - & - & - & 69 & - & - & - & - & 212 & 833 & 586 \\
\hline Pioneiros & Sud Menucci & 100 & - & - & - & - & 124 & - & - & - & - & 239 & 895 & 620 \\
\hline Pitangueiras & Pitangueiras & - & 94 & - & - & - & - & - & 57 & 57 & 80 & - & 771 & 423 \\
\hline Pyles & Platina & 285 & - & - & - & - & - & 19 & - & - & - & 119 & 546 & 490 \\
\hline Quatá & Quatá & 146 & - & - & - & - & - & 88 & - & - & - & 42 & 615 & 559 \\
\hline Rafard & Rafard & - & - & - & - & 43 & - & - & - & - & - & - & 457 & 211 \\
\hline Santa Adélia & Jaboticabal & - & 66 & - & - & - & - & - & 29 & 64 & 68 & - & 762 & 414 \\
\hline Santa Cândida & Bocaina & - & 66 & - & 82 & 224 & - & - & 143 & 145 & - & - & 648 & 375 \\
\hline Santa Cruz & Américo Brasiliense & - & 11 & - & - & - & - & - & 58 & 71 & - & - & 707 & 359 \\
\hline Santa Elisa & Sertãozinho & - & 95 & - & - & - & - & - & 38 & 24 & - & - & 738 & 390 \\
\hline Santa Fé & Nova Europa & - & 47 & - & 118 & 246 & - & - & 99 & 126 & 90 & - & 743 & 395 \\
\hline Santa Helena & Rio das Pedras & - & 149 & - & 196 & 64 & - & - & - & - & - & - & 490 & 238 \\
\hline Santa Inês & Sertãozinho & - & 95 & - & - & - & - & - & 38 & 24 & - & - & 738 & 390 \\
\hline Santa Isabel & Novo Horizonte & - & - & - & - & - & - & - & 143 & 179 & 72 & - & 748 & 482 \\
\hline Santa Luiza & Motuca & - & 60 & - & - & - & - & - & 49 & 88 & - & - & 756 & 408 \\
\hline Santa Maria & Cerquilho & - & - & - & - & 9 & - & - & - & - & - & - & 441 & 194 \\
\hline Santa Rita & Santa Rita do Passa Quatro & - & 117 & - & - & - & - & - & 92 & 73 & - & - & 658 & 310 \\
\hline Santa Rosa (Boituva) & Boituva & - & - & - & - & 10 & - & - & - & - & - & - & 432 & 185 \\
\hline Santo Antônio (USA) & Sertãozinho & - & 95 & - & - & - & - & - & 38 & 24 & - & - & 738 & 390 \\
\hline São Carlos & Jaboticabal & - & 66 & - & - & - & - & - & 29 & 64 & 68 & - & 762 & 414 \\
\hline São Domingos & Catanduva & - & - & - & - & - & - & - & 123 & 159 & 22 & - & 810 & 462 \\
\hline São Francisco (UFRA & Sertãozinho & - & 95 & - & - & - & - & - & 38 & 24 & - & - & 738 & 390 \\
\hline São José & Rio das Pedras & - & - & - & - & 64 & - & - & - & - & - & - & 490 & 238 \\
\hline São José (ZL) & Macatuba & - & 122 & - & 54 & 184 & - & - & - & - & - & - & 608 & 361 \\
\hline São José da Estiva & Novo Horizonte & - & - & - & - & - & - & - & 143 & 179 & 72 & - & 748 & 482 \\
\hline São Manuel & São Manuel & - & 133 & - & 78 & 148 & - & - & - & - & - & - & 572 & 325 \\
\hline São Martinho & Pradópolis & - & 66 & - & - & - & - & - & 10 & 49 & - & - & 735 & 387 \\
\hline Sobar & Espírito Santo do Turvo & - & 194 & - & 59 & 207 & - & - & - & - & - & - & 574 & 384 \\
\hline Unialco & Guararapes & 70 & - & - & - & - & 162 & 306 & - & - & - & 129 & 787 & 585 \\
\hline Univalem & Valparaíso & 80 & - & - & - & - & 181 & 325 & - & - & - & 127 & 806 & 590 \\
\hline Vale do Rosário & Orlândia & - & 136 & - & - & - & - & - & 96 & 60 & - & - & 771 & 423 \\
\hline Virálcool & Pitagueiras & - & 94 & - & - & - & - & - & 57 & 57 & 80 & - & 771 & 423 \\
\hline Vista Alegre & Itapetininga & - & - & - & - & 62 & - & - & - & - & - & - & 431 & 239 \\
\hline Zanin & Araraquara & - & 10 & - & - & - & - & - & 66 & 79 & - & - & 696 & 348 \\
\hline
\end{tabular}

Quadro 14 - Distâncias entre origens e destinos de rotas consideradas

Fonte: Guia quatro rodas rodoviário (2004) 
Tabela 12. Momentos de transporte utilizados para obtenção do frete

\begin{tabular}{|c|c|c|c|c|c|}
\hline \multirow{2}{*}{$\begin{array}{l}\text { Faixa de } \\
\text { Distância } \\
(\mathrm{km})\end{array}$} & \multicolumn{3}{|c|}{ Frete Unitário (R\$/t.km) } & \multirow[b]{2}{*}{ Ferroviário } & \multirow[b]{2}{*}{ Observações } \\
\hline & $\begin{array}{c}\text { Ponta } \\
\text { Rodoviária }\end{array}$ & $\begin{array}{l}\text { Santos } \\
\text { Médio }\end{array}$ & $\begin{array}{c}\text { Paranaguá } \\
\text { Médio }\end{array}$ & & \\
\hline $0-25$ & 0,182 & & & & \multirow{8}{*}{$\begin{array}{l}\text { Utilizado para cálculo dos fretes das pontas } \\
\text { rodoviárias (Usina - Terminal). O frete unitário } \\
\text { da faixa } 126 \text { - } 150 \mathrm{~km} \text { foi repetido para as faixas } \\
151-200 \mathrm{~km} \text { e } 201 \text { - } 250 \text { por falta de dados. }\end{array}$} \\
\hline $26-50$ & 0,134 & & & & \\
\hline $51-75$ & 0,112 & & & & \\
\hline $76-100$ & 0,109 & & & & \\
\hline $101-125$ & 0,104 & & & & \\
\hline $126-150$ & 0,100 & & & & \\
\hline $151-200$ & 0,100 & & & & \\
\hline $201-250$ & 0,100 & & & & \\
\hline $101-200$ & & 0,157 & & & \multirow{9}{*}{$\begin{array}{c}\text { Utilizado para cáculo dos fretes de exportação } \\
\text { (Usina - Porto). O frete unitário para Paranaguá } \\
\text { da faixa } 801-900 \mathrm{~km} \text { foi repetido para a faixa } \\
901-1000 \mathrm{~km} \text { por falta de dados. }\end{array}$} \\
\hline $201-300$ & & 0,147 & & 0,0992 & \\
\hline $301-400$ & & 0,136 & & n.d. & \\
\hline $401-500$ & & 0,124 & 0,094 & 0,0596 & \\
\hline $501-600$ & & 0,107 & 0,095 & 0,0605 & \\
\hline $601-700$ & & 0,101 & 0,100 & 0,0540 & \\
\hline $701-800$ & & 0,098 & 0,083 & 0,0503 & \\
\hline $801-900$ & & & 0,073 & & \\
\hline $901-1000$ & & & 0,073 & & \\
\hline
\end{tabular}

Fonte: elaborado a partir do SIFRECA e de agentes do mercado 


\begin{tabular}{|c|c|c|c|c|c|c|c|c|c|c|c|c|c|c|}
\hline Usina & Município & Araçatuba & $\begin{array}{c}\text { Araraquar } \\
\mathrm{a}\end{array}$ & Barretos & Bauru & Boituva & $\begin{array}{c}\text { Fernandó } \\
\text { polis }\end{array}$ & Palmital & $\begin{array}{c}\text { Pradópoli } \\
\mathrm{s}\end{array}$ & $\begin{array}{c}\text { Ribeirão } \\
\text { Preto }\end{array}$ & $\begin{array}{l}\text { Santa } \\
\text { Adélia }\end{array}$ & Tupã & Santos & \begin{tabular}{|l} 
Paranag \\
uá
\end{tabular} \\
\hline Água Bonita & Tarumã & 20,70 & & & - & - & & 6,71 & . & & - & 11,04 & 55,50 & 54,82 \\
\hline Albertina & Sertãozinho & - & 10,38 & - & - & - & - & - & 5,10 & 4,37 & - & - & 53,04 & 61,21 \\
\hline Alcoazul & Araçatuba & 3,65 & - & - & - & - & 14,00 & 28,20 & $\cdot$ & - & - & 11,25 & 58,59 & 63,28 \\
\hline Alcoeste & Fernandópolis & 14,00 & - & - & - & - & 1,82 & - & - & - & - & 24,70 & 64,55 & 65,12 \\
\hline Alcomira & Mirandópolis & 9,84 & - & - & - & - & 21,10 & - & - & - & - & 15,70 & 61,72 & 61,03 \\
\hline Alta Mogiana & São Joaquim da Barra & - & 15,60 & - & - & - & - & - & 12,08 & 8,75 & - & - & 54,93 & 65,60 \\
\hline Alto Alegre & Presidente Prudente & 16,90 & - & - & - & - & - & 15,40 & - & - & - & 10,73 & 63,24 & 64,10 \\
\hline Andrade & Pitangueiras & - & 10,28 & - & - & - & - & - & 6,36 & 6,36 & 8,75 & - & 52,45 & 63,94 \\
\hline Aralco & Sto. Antônio do Aracanguá & 6,04 & - & - & - & - & 11,66 & - & - & - & - & 14,50 & 62,85 & 58,47 \\
\hline Barra Grande & Lençóis Paulista & - & 13,70 & - & 6,31 & 17,30 & - & - & - & - & - & - & 47,60 & 56,72 \\
\hline Bazan & Pontal & - & 11,87 & - & - & - & - & - & 6,14 & 5,77 & - & - & 50,72 & 62,78 \\
\hline Bela Vista & Pontal & - & 11,87 & - & - & - & - & - & 6,14 & 5,77 & - & - & 50,72 & 62,78 \\
\hline Benálcool & Bento de Abreu & 6,71 & - & - & - & - & 18,10 & 32,50 & - & - & - & 14,80 & 63,92 & 58,84 \\
\hline Bertolo & Pirangi & - & - & - & - & - & - & - & 8,75 & 11,97 & 4,01 & - & 57,04 & 58,98 \\
\hline Branco Peres & Adamantina & 12,50 & - & - & - & - & 24,60 & 19,30 & - & - & - & 7,48 & 65,77 & 59,55 \\
\hline Campestre & Penápolis & 7,81 & - & - & - & - & 17,30 & 24,00 & - & - & - & 9,18 & 54,86 & 59,80 \\
\hline Catanduva & Ariranha & - & - & - & - & - & - & - & 10,06 & 12,70 & 2,73 & - & 56,79 & 58,84 \\
\hline CBA (antiga Sanagro & Icém & - & - & 9,95 & - & - & - & - & 18,00 & 18,90 & - & - & 60,72 & 67,01 \\
\hline Central Paulista & Jaú & & 8,42 & - & 6,58 & 20,10 & - & - & - & - & - & - & 47,06 & 62,41 \\
\hline Centrálcool & Lucélia & 11,45 & - & - & $\cdot$ & - & 25,10 & 18,80 & - & - & - & 6,92 & 63,92 & 59,30 \\
\hline Cerradinho & Catanduva & - & - & - & - & - & - & - & 12,81 & 15,90 & 4,01 & - & 57,29 & 59,13 \\
\hline Clealco & Clementina & 6,04 & - & - & - & - & 18,70 & 19,00 & - & - & - & 7,14 & 59,12 & 63,03 \\
\hline Cocal & Paraguaçu Paulista & 17,60 & - & - & - & - & - & 7,14 & - & - & - & 8,03 & 56,99 & 56,15 \\
\hline Colombo & Ariranha & - & - & - & - & - & - & - & 10,06 & 12,70 & 2,73 & - & 56,79 & 58,84 \\
\hline Colorado & Guaíra & - & - & 5,24 & - & - & - & - & 15,40 & 13,90 & - & - & 53,48 & 62,05 \\
\hline Corona & Guariba & - & - & - & - & - & - & - & 3,28 & 7,14 & 9,29 & - & 51,09 & 63,03 \\
\hline Costa Pinto & Piracaba & - & - & - & - & 7,25 & - & - & - & - & - & - & 32,78 & 54,25 \\
\hline Da Barra & Barra Bonita & - & 10,62 & - & 9,18 & 18,00 & - & - & - & - & - & - & 48,55 & 60,31 \\
\hline Da Pedra & Serrana & - & 11,04 & - & - & - & - & - & 8,31 & 4,70 & - & - & 51,41 & 60,21 \\
\hline Da Serra & Ibaté & - & 3,89 & - & - & - & - & - & 9,95 & 10,83 & - & - & 44,47 & 67,40 \\
\hline Dacal & Parapuã & 8,75 & - & - & - & - & 23,60 & 16,30 & - & - & - & 4,97 & 61,79 & 68,90 \\
\hline Dalsa & Monte Aprazivel & 13,00 & - & - & - & - & 10,73 & - & - & - & - & 19,20 & 59,44 & 58,55 \\
\hline DC & Dois Córregos & - & 9,62 & - & 9,40 & 20,00 & - & - & - & - & - & - & 44,20 & 62,31 \\
\hline Della Coletta & Bariri & - & 9,95 & - & - & 24,20 & - & - & - & - & - & - & 53,99 & 66,50 \\
\hline Destil & Itajobi & - & - & - & - & - & - & - & 12,90 & 16,50 & 4,97 & - & 58,03 & 59,57 \\
\hline Destivale & Araçatuba & 3,65 & - & - & - & - & 14,00 & 28,20 & - & - & - & 11,25 & 58,59 & 63,28 \\
\hline Diamante & Jaú & - & 8,42 & - & - & 20,10 & - & - & - & - & - & - & 47,06 & 62,41 \\
\hline Diana & Avanhadava & 9,29 & - & - & - & - & 18,70 & 22,70 & - & - & - & 10,71 & 53,37 & 58,72 \\
\hline Equipav & Promissão & 8,96 & - & - & - & - & 20,50 & 21,40 & - & - & - & 11,87 & 54,97 & 69,40 \\
\hline Ester & Cosmópolis & - & - & - & - & 12,60 & - & - & - & - & - & - & 31,09 & 51,87 \\
\hline Floralco & Flórida Paulista & 13,00 & - & - & - & - & 24,70 & 20,70 & - & - & - & 8,85 & 63,75 & 60,87 \\
\hline Furlan & Santa Barbara D'Oeste & 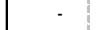 & - & - & - & 8,42 & - & - & - & - & - & - & 29,84 & 52,35 \\
\hline Galo Bravo & Ribeirão Preto & & 8,64 & - & - & - & - & - & 6,58 & 1,82 & - & - & 50,05 & 59,38 \\
\hline Gasa & Andradina & 13,00 & - & - & - & - & 17,90 & - & - & - & - & 19,80 & 65,77 & 64,02 \\
\hline Grizzo & Jaú & - & 8,42 & - & 6,58 & 20,10 & - & - & - & - & - & - & 47,06 & 62,41 \\
\hline Guaíra & Guaíra & - & - & 5,24 & - & - & - & - & 15,40 & 13,90 & - & - & 53,48 & 62,05 \\
\hline Guarani (Cruz Alta) & Olímpia & - & - & 6,71 & - & - & - & - & 13,10 & 14,00 & 8,31 & - & 55,18 & 63,22 \\
\hline Guarani (Severínia) & Severínia & - & - & 5,80 & - & - & - & - & 12,18 & 12,60 & 6,92 & - & 54,33 & 62,63 \\
\hline Guaricanga & Presidente Alves & - & 18,50 & - & - & 27,00 & - & - & - & - & - & - & 55,43 & 67,20 \\
\hline Ibirá & Santa Rosa do Viterbo & - & 11,87 & - & - & & - & - & 10,06 & 7,36 & - & - & 45,56 & 68,20 \\
\hline Ipaussu & Ipauçu & - & - & - & - & 25,10 & - & - & - & - & - & - & 53,07 & 51,02 \\
\hline Ipiranga (Matriz) & Descalvado & - & 8,85 & - & - & - & - & - & 11,97 & 10,49 & - & - & 43,81 & 64,50 \\
\hline Iracema & Iracemópolis & - & - & - & - & 10,06 & - & - & - & - & - & - & 34,25 & 55,20 \\
\hline Jardest & Jardinópolis & - & 10,73 & - & - & - & - & - & 7,03 & 3,63 & - & - & 53,04 & 61,21 \\
\hline Londra & Itaí & - & 22,50 & - & 16,30 & 18,80 & - & - & - & - & - & - & 49,64 & 45,40 \\
\hline Malosso & Itápolis & - & 8,31 & - & 11,97 & 27,50 & - & - & 10,60 & 13,30 & 6,69 & - & 52,58 & 64,03 \\
\hline
\end{tabular}

Quadro 15 - Custos de transporte entre origens e destinos 


\begin{tabular}{|c|c|c|c|c|c|c|c|c|c|c|c|c|c|c|}
\hline Usina & Município & Araçatuba & $\begin{array}{c}\text { Araraquar } \\
\mathrm{a}\end{array}$ & Barretos & Bauru & Boituva & $\begin{array}{c}\text { Fernandó } \\
\text { polis }\end{array}$ & Palmital & $\begin{array}{c}\text { Pradópoli } \\
\text { S }\end{array}$ & $\begin{array}{l}\text { Ribeirão } \\
\text { Preto }\end{array}$ & $\begin{array}{l}\text { Santa } \\
\text { Adélia }\end{array}$ & Tupã & Santos & $\begin{array}{l}\text { Paranag } \\
\text { uá }\end{array}$ \\
\hline Mandu & Guaíra & & - & 5,24 & - & $\overline{-}$ & - & - & 15,40 & 13,90 & - & $\overline{-}$ & 53,48 & 62,05 \\
\hline Maracaí & Maracaí & 19,40 & - & - & - & - & - & 6,47 & - & - & - & 10,17 & 56,35 & 55,58 \\
\hline Maringá & Araraquara & - & 1,82 & - & . & - & . & - & 7,36 & 8,64 & - & - & 47,33 & 69,50 \\
\hline MB & Morro Agudo & - & 14,00 & . & . & . & - & - & 11,56 & 8,37 & - & . & 54,31 & 65,19 \\
\hline Moema & Orindiúva & . & - & 12,70 & . & . & - & - & 21,10 & 22,00 & . & . & 63,71 & 69,06 \\
\hline Moreno & Monte Aprazível & 13,00 & . & - & . & . & 10,73 & - & - & - & . & 19,20 & 59,44 & 58,55 \\
\hline Moreno & Luís Antônio & - & 8,31 & . & . & . & . & - & 6,02 & 6,58 & . & - & 45,29 & 68,00 \\
\hline Nardini & Vista Alegre do Alto & . & . & . & . & . & . & . & 8,03 & 11,14 & 3,89 & . & 55,92 & 66,26 \\
\hline Nossa Senhora de Ap & Pontal & - & 11,87 & - & - & - & - & - & 6,14 & 5,77 & - & - & 50,72 & 62,78 \\
\hline Nova América & Tarumã & 20,70 & - & - & - & - & - & 6,71 & 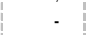 & - & - & 11,04 & 55,50 & 54,82 \\
\hline Paraíso Bioenergia & Brotas & - & 10,73 & - & 12,29 & 13,10 & - & 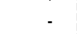 & . & . & . & - & 43,93 & 67,00 \\
\hline Parálcool & Paraguaçu Paulista & 17,60 & $\cdot$ & - & $\cdot$ & $\cdot$ & - & 7,14 & - & - & - & 8,03 & 56,99 & 56,15 \\
\hline Pederneiras & Tietê & $\cdot$ & - & - & - & 3,46 & - & - & - & - & - & $\cdot$ & 29,99 & 42,39 \\
\hline Petribú Paulista & Sebastianópolis do Sul & 11,04 & - & - & - & - & 7,70 & - & - & - & - & 21,20 & 62,43 & 60,81 \\
\hline Pioneiros & Sud Menucci & 10,93 & - & - & - & - & 12,91 & - & - & - & - & 23,90 & 62,73 & 65,34 \\
\hline Pitangueiras & Pitangueiras & - & 10,28 & . & . & . & - & . & 6,36 & 6,36 & 8,75 & - & 52,45 & 63,94 \\
\hline Pyles & Platina & 28,50 & - & - & - & - & - & 3,46 & . & - & - & 12,39 & 60,76 & 51,87 \\
\hline Quatá & Quatá & 14,60 & - & - & - & - & - & 9,62 & - & - & - & 5,64 & 59,55 & 61,41 \\
\hline Rafard & Rafard & - & - & - & - & 5,77 & - & - & - & - & - & - & 31,02 & 42,96 \\
\hline Santa Adélia & Jaboticabal & . & 7,36 & - & - & - & . & - & 3,89 & 7,14 & 7,59 & - & 51,34 & 63,20 \\
\hline Santa Cândida & Bocaina & - & 7,36 & - & 8,96 & 22,40 & - & - & 14,30 & 14,50 & - & - & 51,00 & 64,70 \\
\hline Santa Cruz & Américo Brasiliense & - & 2,00 & - & - & $\cdot$ & - & - & 6,47 & 7,92 & - & . & 48,82 & 58,63 \\
\hline Santa Elisa & Sertãozinho & - & 10,38 & - & - & - & - & - & 5,10 & 4,37 & - & - & 53,04 & 61,21 \\
\hline Santa Fé & Nova Europa & - & 6,31 & - & 12,29 & 24,60 & - & - & 10,82 & 12,60 & 9,84 & . & 53,72 & 61,62 \\
\hline Santa Helena & Rio das Pedras & . & 14,90 & . & 19,60 & 7,14 & . & . & . & - & . & . & 34,99 & 46,06 \\
\hline Santa Inês & Sertãozinho & . & 10,38 & . & - & - & . & . & 5,10 & 4,37 & . & . & 53,04 & 61,21 \\
\hline Santa Isabel & Novo Horizonte & - & - & - & - & - & - & - & 14,30 & 17,90 & 8,03 & . & 59,77 & 62,04 \\
\hline Santa Luiza & Motuca & - & 6,69 & - & - & - & - & - & 6,58 & 9,62 & . & . & 50,59 & 62,70 \\
\hline Santa Maria & Cerquilho & - & - & - & - & 1,64 & - & - & 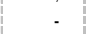 & 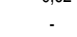 & . & . & 30,46 & 41,45 \\
\hline Santa Rita & Santa Rita do Passa Quatro & - & 12,18 & - & - & - & - & - & 10,06 & 8,14 & - & - & 42,16 & 65,70 \\
\hline Santa Rosa (Boituva) & Boituva & - & - & - & - & 1,82 & - & - & - & - & - & - & 29,05 & 40,61 \\
\hline Santo Antônio (USA) & Sertãozinho & - & 10,38 & - & - & - & - & - & 5,10 & 4,37 & - & - & 53,04 & 61,21 \\
\hline São Carlos & Jaboticabal & . & 7,36 & . & . & . & . & . & 3,89 & 7,14 & 7,59 & . & 51,34 & 63,20 \\
\hline São Domingos & Catanduva & - & - & - & - & - & - & - & 12,81 & 15,90 & 4,01 & - & 57,29 & 59,13 \\
\hline São Francisco (UFRA & Sertãozinho & - & 10,38 & - & - & . & - & - & 5,10 & 4,37 & - & - & 53,04 & 61,21 \\
\hline São José & Rio das Pedras & . & - & - & - & 7,14 & - & - & - & - & - & - & 34,99 & 46,06 \\
\hline São José (ZL) & Macatuba & - & 12,70 & - & 6,02 & 18,40 & - & - & - & - & - & - & 49,10 & 60,71 \\
\hline São José da Estiva & Novo Horizonte & - & - & - & - & $\cdot$ & - & - & 14,30 & 17,90 & 8,03 & - & 59,77 & 62,04 \\
\hline São Manuel & São Manuel & - & 13,30 & - & 8,53 & 14,80 & - & - & $\cdot$ & - & - & . & 44,20 & 54,34 \\
\hline São Martinho & Pradópolis & - & 7,36 & - & - & - & - & - & 1,82 & 6,58 & - & - & 52,63 & 60,96 \\
\hline Sobar & Espírito Santo do Turvo & - & 19,40 & . & 6,58 & 20,70 & - & - & 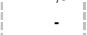 & - & - & - & 52,22 & 54,53 \\
\hline Unialco & Guararapes & 7,81 & - & . & . & - & 16,20 & 30,60 & . & . & . & 12,90 & 62,32 & 65,27 \\
\hline Univalem & Valparaíso & 8,75 & - & - & - & - & 18,10 & 32,50 & - & - & - & 12,70 & 62,85 & 58,84 \\
\hline Vale do Rosário & Orlândia & - & 13,60 & - & - & - & - & - & 10,49 & 6,69 & . & - & 52,45 & 63,94 \\
\hline Virálcool & Pitagueiras & - & 10,28 & - & - & - & - & - & 6,36 & 6,36 & 8,75 & - & 52,45 & 63,94 \\
\hline Vista Alegre & Itapetininga & - & - & - & - & 6,92 & - & - & $\cdot$ & - & - & - & 35,13 & 40,51 \\
\hline Zanin & Araraquara & . & 1,82 & . & . & - & . & . & 7,36 & 8,64 & . & . & 47,33 & 69,50 \\
\hline
\end{tabular}

Quadro 15 - Custos de transporte entre origens e destinos

Fonte: elaborado a partir do SIFRECA e agentes do mercado 


\section{REFERÊNCIAS BIBLIOGRÁFICAS}

ALVES, L.R.A. Transmissão de preços entre produtos do setor sucroalcooleiro do estado de São Paulo. Piracicaba, 2002. 107p. Dissertação (M.S.) - Escola Superior de Agricultura "Luiz de Queiroz", Universidade de São Paulo.

AMARO, A.A.; SILVA J. F. G. Desenvolvimento da citricultura e localização de novas indústrias para o processamento no estado de São Paulo. Piracicaba: ESALQ, Depto. Economia, Administração e Sociologia, 1973. 78p. (Série Pesquisa, 22)

ARALCO S.A. Terminal rodoferroviário. http://www.aralco.com.br/ (15 jan. 2005)

ASSOCIAÇÃO BRASILEIRA DA INDÚSTRIA FERROVIÁRIA (ABIFER).

Indústria. http://www.abifer.org.br (10 fev. 2005)

ASSOCIAÇÃO NACIONAL DOS TRANSPORTADORES FERROVIÁRIOS (ANTF).

Contribuições e desafios do setor ferroviário. /Apresentado ao Seminário Brasil nos Trilhos, Brasília, 2004/ http://www.antf.org.br/150anos.htm\#pag03 (17 jan. 2005)

ASSOCIAÇÃO NACIONAL DOS TRANSPORTADORES TERRESTRES (ANTT).

Transporte de cargas. http://www.antt.gov.br (02 set. 2004)

AZZONI, C.R. Teoria da localização: análise crítica a partir de evidências empíricas no estado de São Paulo. São Paulo, 1982. 141p. Tese (Doutorado) - Faculdade de Economia e Administração, Universidade de São Paulo. 
BANCO NO NORDESTE DO BRASIL. Manual de localização industrial: tentativa de adequação da teoria à realidade. Rio de Janeiro: APEC, 1968. 223p.

BARROS, G.S.A. de C. Economia da comercialização agrícola. Piracicaba: FEALQ, 2004. $227 p$.

BELIK, W.; RAMOS, P.; VIAN, C.E.F. Mudanças institucionais e seus impactos nas estratégias dos capitais do complexo agroindustrial canavieiro no Centro-Sul do Brasil (compact disc). In: CONGRESSO BRASILEIRO DE ECONOMIA E SOCIOLOGIA RURAL, 36., Poços de Caldas, 1998. Anais. Brasília: SOBER, 1998.

BESKOW, P.; DECKERS, D. Capacidade brasileira de armazenagem. In: LORINI, I.; MIIKE, L.H.; SCUSSEL, V.M. Armazenagem de grãos. Campinas: IBG, 2002. cap.3.1, p.99-115: Capacidade brasileira de armazenagem.

BRASIL. Governo Federal. Guia brasileiro de investimento. http://www.brasil.gov.br/investment/port_tot.pdf (25 set. 2004a)

BRASIL. Ministério dos Transportes. Mapas e informações. http://www.transportes.gov.br/. (20 ago. 2004b)

BRASIL. Secretaria de Comércio Exterior (SECEX). Sistema de análise das informações de comércio exterior ALICE-Web. http://aliceweb.desenvolvimento.gov.br/ (10 fev. 2005)

BRASIL FERROVIAS. A Brasil Ferrovias. http://www.brasilferrovias.com.br (28 fev. 2005)

BRITO, A. Brasil Ferrovias fecha contrato de 10 anos com a Bunge Alimentos. O Estado de São Paulo, São Paulo, 15 fev. 2005. p.B6.

BRITO, A. Trading investe para movimentar açúcar. Gazeta Mercantil, São Paulo, 05 mar. 2004. p.A14. 
CAIXETA-FILHO, J.V. Pesquisa operacional: técnicas de otimização aplicadas a sistemas agroindustriais. São Paulo: Atlas, 2001. 171p.

CAIXETA-FILHO, J.V.; MARTINS, R.S.; OLIVEIRA, J.C.V. et al. Particularidades das modalidades de transporte. In: CAIXETA-FILHO, J.V.; GAMEIRO, A.H. (Org.). Transporte e logística em sistemas agroindustriais. São Paulo: Atlas, 2001. p.62-135.

CAMARGO, A.A.S. de. As PPPs são viáveis ou apenas conjecturas? Valor Econômico, 25 ago. 2004. p.E2.

CASTRO, N. Estrutura, desempenho e perspectivas do transporte ferroviário de carga, 2001. http://www.nemesis.org.br (20 jan. 2005)

CENTRO DE ESTUDOS EM LOGÍSTICA (CEL/COPPEAD). Transporte de carga no Brasil: ameaças e oportunidades para o desenvolvimento do país. Rio de Janeiro, 2002. 200p.

CENTRO DE ESTUDOS AVANÇADOS EM ECONOMIA APLICADA (CEPEA). PIB do agronegócio cna/cepea-usp: janeiro a dezembro de 2003. http://www.cepea.esalq.usp.br/pib/2003/jan_dez.pdf (26 maio 2004)

COSAN. Grupo Cosan. http://www.cosan.com.br (22 ago. 2004)

COMPANHIA NACIONAL DE ABASTECIMENTO (CONAB). Armazenagem. http://www.conab.gov.br/ (06 set. 2004)

COPERSUCAR. Produtos. http://www.copersucar.com.br/\# (22 ago. 2004)

GASQUES, J.G.; BASTOS, E. Crescimento da agricultura. Boletim de Conjuntura Ipea, n.60, p.85-93, mar. 2003.

GAZETA MERCANTIL. Análise setorial: o futuro do transporte rodoviário de cargas. São Paulo, dez. 2000. 2v. (Panorama setorial) 
GAZETA MERCANTIL. Análise setorial: transporte ferroviário de cargas. São Paulo, out. 2001. 2v. (Panorama setorial)

GUIA QUATRO RODAS RODOVIÁRIO (compact disc). São Paulo: Abril, 2004.

INSTITUTO BRASILEIRO DE GEOGRAFIA E ESTATÍSTICA (IBGE). Sistema de recuperação automática: SIDRA. http://www.sidra.ibge.gov.br/bda/ (15 ago. 2004)

JANK, M.S. Em defesa das commodities. O Estado de São Paulo, São Paulo, 06 jul. 2004. p.A2.

LESSA, C. Quinze anos de política econômica. São Paulo: Brasiliense, 1983. 220p.

LOPES, R.L. Suinocultura no estado de Goiás: aplicação de um modelo de localização. Piracicaba, 1997. 95p. Dissertação (M.S.) - Escola Superior de Agricultura "Luiz de Queiroz”, Universidade de São Paulo.

MAgAlhães, M. Compra da Destivale pelo grupo FBA é consolidada. http://www.jornalcana.com.br (23 jan. 2005)

MELO, F.H.; FONSECA, E.G. Proálcool, energia e transportes. São Paulo: Editora Pioneira/FIPE, 1981. 217p.

MORAES, M.A.F.D. de. A desregulamentação do setor sucroalcooleiro do Brasil. Americana: Caminho Editorial, 2000. 238p.

MORAES, M.A.F.D. de. A cadeia produtiva da cana, em mercado desregulamentado. Visão Agrícola, v.1, p.94-99, jan./jul. 2004.

NAZÁRIO, P.; WANKE, P.; FLEURY, P.F. O papel do transporte na estratégia logística. http://www.coppead.ufrj.br/pesquisa/cel/new/fs-busca.htm?fr-gest-trans _rj.htm (23 ago. 2004)

NECESSIDADE se transformou em bom negócio. O Estado de São Paulo, São Paulo, 10 jan. 2005. p.B4. 
PEREIRA, R. Empresas criam logística própria. O Estado de São Paulo, São Paulo, 10 jan. 2005. p.B3.

PINAZZA, L.A.; ALIMANDRO, R. Cana-de-açúcar: alimento bom e doce. http://www.unica.com.br/pages/publicacoes_6.asp (15 abr. 2005)

PORTOS de SP, RJ e MA serão os primeiros alvos das parcerias. Folha de São Paulo. São Paulo, 05 set. 2004. p.B3.

PROCANA. Seção técnica. http://www.canaweb.com.br/ (15 ago. 2004)

RAMOS, S.Y. Avaliação da localização de packing-houses no estado de São Paulo: o caso da laranja de mesa. Piracicaba, 2001. 132p. Dissertação (M.S.) - Escola Superior de Agricultura “Luiz de Queiroz”, Universidade de São Paulo.

RAMOS, P.; BELIK, W. Intervenção estatal e a agroindústria canavieira no Brasil. Revista de Economia e Sociologia Rural, v.27, n.2, p.197-214, abr./jun. 1989.

RUSSEL, S.H. Growing world of logistics. Air Force Journal of Logistics, v.24, n.3, p.12-14, Dec. 2000.

SASSERON, J.L. Armazenamento de grãos. In: GOMES, R.A.R.; CASTRO, M.F.P.M.; VALENTINI, S.R.T.; BOLONHEZI, S. (Coord.). Atualização em tecnologia de pós-colheita de grãos. Campinas: Instituto de Tecnologia de Alimentos (ITAL), 1995. p.50-87.

UNIÃO DA AGROINDÚSTRIA CANAVIEIRA DE SÃO PAULO (UNICA). Referência. http://www.portalunica.com.br/ (10 jun. 2004)

UNIÃO DA AGROINDÚSTRIA CANAVIEIRA DE SÃO PAULO (UNICA). Referência. http://www.portalunica.com.br/ (20 fev. 2005) 
UNITED STATES DEPARTMENT OF AGRICULTURE (USDA). World centrifugal sugar production, supply and distribution. http://www.fas.usda.gov/psd/complete_tables/HTP-table10-91.htm (15 May 2004)

VIAN, C.E.F. Agroindústria canavieira: estratégias competitivas e modernização. Campinas: Editora Átomo, 2003. 216p.

WILLIAMS, H.P. Model building in mathematical programming. Chichester: John Wiley \& Sons, 1993. 355p. 
APÊNDICES 
APÊNDICE 1 - Comandos utilizados no software GAMS para a formulação do cenário 1

SETS

I usinas /U1, U2 , U3 , U4, U5 , U6 , U7, U8, U9, U10, U11, U12, U13, U14, U15, U16, U17, U18, U19, U20, U21, U22, U23, U24, U25, U26, U27, U28, U29, U30, U31, U32, U33, U34, U35, U36, U37, U38, U39, U40, U41, U42, U43, U44, U45, U46, U47, U48, U49, U50, U51, U52, U53, U54, U55, U56, U57, U58, U59, U60, U61, U62, U63, U64, U65, U66, U67, U68, U69, U70, U71, U72, U73, U74, U75, U76, U77, U78, U79, U80, U81, U82, U83, U84, U85, U86, U87, U88, U89, U90, U91, U92, U93, U94, U95, U96, U97, U98, U99, U100, U101, U102, U103/

$\mathrm{J}$ armazens /A1, A2, A3, A4, A5, A6, A7, A8, A9, A10, A11/

$\mathrm{K}$ porto /P1, P2/

T tamanho do armazem /T1, T2, T3, T4, T5, T6, T7, T8, T9, T10/;

\section{PARAMETERS}

$\mathrm{S}(\mathrm{I})$ capacidade de producao das usinas

$\begin{array}{cl}\text { / U1 } & 0 \\ \text { U2 } & 90 \\ \text { U3 } & 26 \\ \text { U4 } & 0 \\ \text { U5 } & 12 \\ & \cdot \\ \cdot & \\ \text { U103 } & \\ & 82 /\end{array}$

CAP(T) capacidade dos armazens de tamanho $t$ localizados em $\mathrm{j}$

/T1 30

$\mathrm{T} 2 \quad 50$

T3 70

T4 100

T5 150

T6 200

T7 250 
T8 300

T9 400

$\mathrm{T} 10500 /$

EXPORT(K) demanda dos portos

/P1 6400

P2 600/

$\mathrm{CO}(\mathrm{T})$ custo operacional do armazem de tamanho $t$ localizados em $\mathrm{j}$ em reais

/T1 210

T2 350

T3 490

T4 700

T5 1050

T6 1400

T7 1750

T8 2100

T9 2800

$\mathrm{T} 103500 /$

$\mathrm{CP}(\mathrm{K})$ custo operacional do porto $\mathrm{k}$

/P1 29.15

P2 25.18/;

TABLE C(I,J) custo unitario de transporte da usina $\mathrm{i}$ ate $\mathrm{o}$ armazem $\mathrm{j}$

$\begin{array}{lllll}\text { A1 } & \text { A2 } & \text { A3 } & \text { A4 } & \text { A5 }\end{array}$

\begin{tabular}{|c|c|c|c|c|c|}
\hline U1 & 20.70 & 1000.00 & 1000.00 & 1000.00 & 1000.00 \\
\hline U2 & 1000.00 & 10.38 & 1000.00 & 1000.00 & 1000.00 \\
\hline U3 & 3.65 & 1000.00 & 1000.00 & 1000.00 & 1000.00 \\
\hline U4 & 14.00 & 1000.00 & 1000.00 & 1000.00 & 1000.00 \\
\hline U5 & 9.84 & 1000.00 & 1000.00 & 1000.00 & 1000.00 \\
\hline & & & & & \\
\hline & 1000.00 & 1.82 & 1000.00 & 1000.00 & 1000.00 \\
\hline
\end{tabular}

$+$ 


$\begin{array}{cccrc} & \text { A6 } & \text { A7 } & \text { A8 } & \text { A9 } \\ \text { U1 } & 1000.00 & 6.71 & 1000.00 & 1000.00 \\ \text { U2 } & 1000.00 & 1000.00 & 5.10 & 4.37 \\ \text { U3 } & 14.00 & 28.20 & 1000.00 & 1000.00 \\ \text { U4 } & 1.82 & 1000.00 & 1000.00 & 1000.00 \\ \text { U5 } & 21.10 & 1000.00 & 1000.00 & 1000.00 \\ & & & & \\ & \cdot & & & \\ \text { U103 } & 1000.00 & 1000.00 & 7.36 & 8.64\end{array}$

$\begin{array}{lcl} & \text { A10 } & \text { A11 } \\ \mathrm{U} 1 & 1000.00 & 11.04 \\ \mathrm{U} 2 & 1000.00 & 1000.00 \\ \mathrm{U} 3 & 1000.00 & 11.25 \\ \mathrm{U} 4 & 1000.00 & 24.70 \\ \mathrm{U} 5 & 1000.00 & 15.70 \\ & & \\ & \cdot & \\ \mathrm{U} 103 & & \\ & & \\ & & \\ & & \end{array}$

TABLE E(I,K) custo unitario rodov direto da usina $\mathrm{i}$ ate o porto $\mathrm{k}$

P1 P2

U1 $\quad 55.50 \quad 54.82$

U2 $53.04 \quad 61.21$

U3 $\quad 58.59 \quad 63.28$

U4 $64.55 \quad 65.12$

U5 $61.72 \quad 61.03$

$103 \quad 47.33 \quad 69.50 ;$

TABLE D $(\mathrm{J}, \mathrm{K})$ custo unitario de transporte o armazem $\mathrm{j}$ ate o porto $\mathrm{k}$ 


$\begin{array}{lcl} & \text { P1 } & \text { P2 } \\ \text { A1 } & 35.94 & 1000.00 \\ \text { A2 } & 28.01 & 1000.00 \\ \text { A3 } & 36.15 & 1000.00 \\ \text { A4 } & 32.61 & 1000.00 \\ \text { A5 } & 24.51 & 1000.00 \\ \text { A6 } & 39.87 & 1000.00 \\ \text { A7 } & 36.05 & 36.37 \\ \text { A8 } & 31.27 & 1000.00 \\ \text { A9 } & 32.73 & 1000.00 \\ \text { A10 } & 35.39 & 1000.00 \\ \text { A11 } & 35.84 & 1000.00\end{array}$

\section{VARIABLES}

$X(I, J)$ quantidade movimentada via rodovia entre a usina $\mathrm{i}$ e o armazem $\mathrm{j}$

$\mathrm{Y}(\mathrm{J}, \mathrm{K})$ quantidade movimentada via ferrovia entre a armazem $\mathrm{j}$ e o porto $\mathrm{k}$

$\mathrm{Z}(\mathrm{I}, \mathrm{K})$ quantidade movimentada via rodovia direto entre o usina i e o porto $\mathrm{k}$

$\mathrm{W}(\mathrm{K})$ quantidade que chega no porto $\mathrm{k}$

$\mathrm{H}(\mathrm{J})$ custo de operacao do armazem na regiao $\mathrm{j}$

kont1 capacidade total de armazenagem

kont2 total de demanda atendida

kont3 total de acucar armazenado

kont4 total de acucar que e escoado via rodoviario direto

A custo total de movimentacao;

POSITIVE VARIABLES X, Y, Z, W;

BINARY VARIABLE B;

\section{EQUATIONS}

CUSTO funcao objetivo

OFERTA(I) quantidade ofertada pela usina $\mathrm{i}$

CAPARM(J) demanda do armazem $\mathrm{j}$

ENTSAI $(J)$ entrada e saida do armazem

$\operatorname{DEFW}(\mathrm{K}) \quad$ definicao de $\mathrm{w}$ 
DEMPORTO(K) demanda do porto

CUSTOPER(J)

SOUMT(J)

EQKONT1

EQKONT2

EQKONT3

EQKONT4;

CUSTO .. $\mathrm{A}=\mathrm{E}=$

$\mathrm{SUM}((\mathrm{I}, \mathrm{J}), \mathrm{C}(\mathrm{I}, \mathrm{J}) * \mathrm{X}(\mathrm{I}, \mathrm{J}))+\mathrm{SUM}\left((\mathrm{J}, \mathrm{K}), \mathrm{D}(\mathrm{J}, \mathrm{K})^{*} \mathrm{Y}(\mathrm{J}, \mathrm{K})\right)+\mathrm{SUM}((\mathrm{I}, \mathrm{K}), \mathrm{E}(\mathrm{I}, \mathrm{K}) * \mathrm{Z}(\mathrm{I}, \mathrm{K}))+\mathrm{SUM}((\mathrm{K}), \mathrm{W}(\mathrm{K}) * \mathrm{CP}(\mathrm{K}$ )$)+\operatorname{SUM}((\mathrm{J}), \mathrm{H}(\mathrm{J}))$;

OFERTA(I) .. SUM((J),X(I,J)) + SUM((K),Z(I,K)) =L= S(I);

CAPARM(J) .. SUM((I),X(I,J)) $=\mathrm{L}=\mathrm{SUM}((\mathrm{T}), \mathrm{CAP}(\mathrm{T}) * \mathrm{~B}(\mathrm{~J}, \mathrm{~T}))$;

$\operatorname{ENTSAI}(J)$.. SUM((I),X(I,J)) =E= SUM((K),Y(J,K));

$\operatorname{DEFW}(\mathrm{K}) . . \mathrm{SUM}((\mathrm{J}), \mathrm{Y}(\mathrm{J}, \mathrm{K}))+\mathrm{SUM}((\mathrm{I}), \mathrm{Z}(\mathrm{I}, \mathrm{K}))=\mathrm{E}=\mathrm{W}(\mathrm{K})$;

DEMPORTO(K) .. SUM((J),Y(J,K)) + SUM((I),Z(I,K)) =E= EXPORT(K);

$\operatorname{SOUMT}(\mathrm{J})$.. $\mathrm{SUM}(\mathrm{T}, \mathrm{B}(\mathrm{J}, \mathrm{T}))=\mathrm{L}=1$;

CUSTOPER(J) .. H(J)=E= SUM(T, CO(T)*B(J,T));

EQKONT1 .. KONT1 =E= SUM((J,T),CAP(T)*B(J,T));

EQKONT2 .. KONT2 =E= SUM((J,K),Y(J,K));

EQKONT3 .. KONT3 =E= SUM((I,J),X(I,J));

EQKONT4 .. KONT4 =E= SUM((I,K),Z(I,K));

OPTION ITERLIM $=100000000$;

OPTION RESLIM = 100000000;

OPTION OPTCR $=0$;

MODEL TRANSPORTE /ALL/;

SOLVE TRANSPORTE USING MIP MINIMIZING A;

DISPLAY X.L, Y.L, Z.L, B.L, W.L, KONT1.L, KONT2.L, KONT3.L, X.M, B.M, Y.M; 
APÊNDICE 2 - Informações originais de fretes

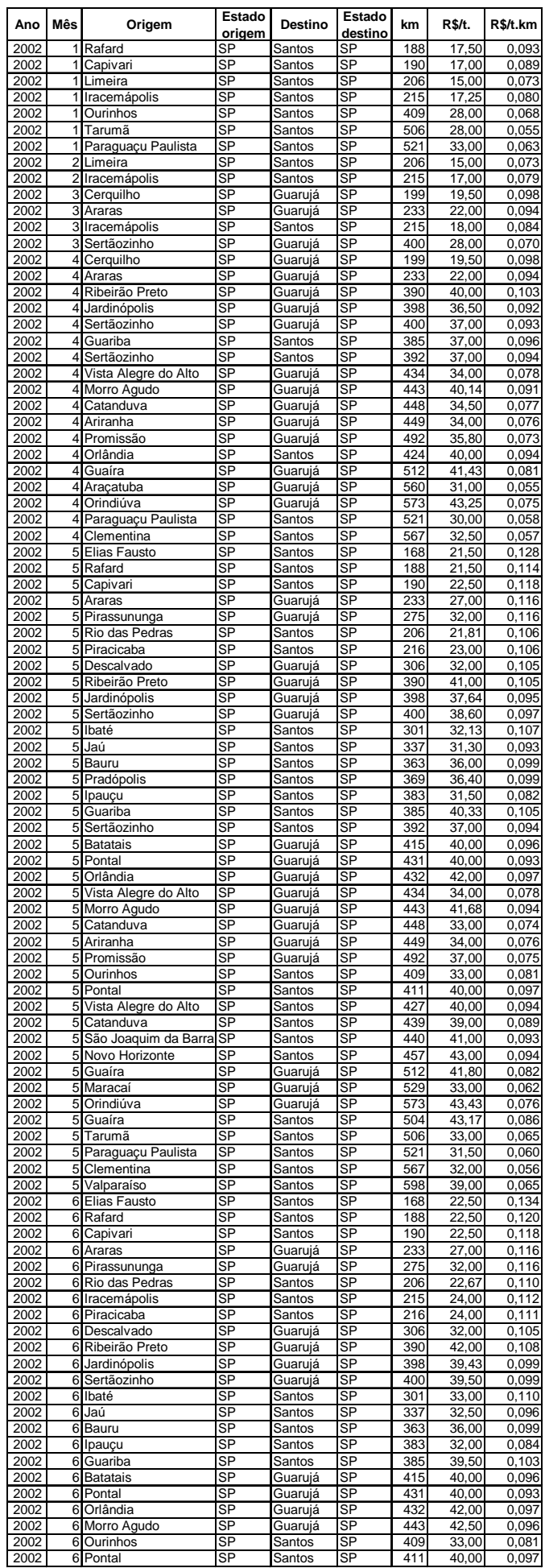

Quadro 16 - Fretes rodoviários para açúcar a granel 


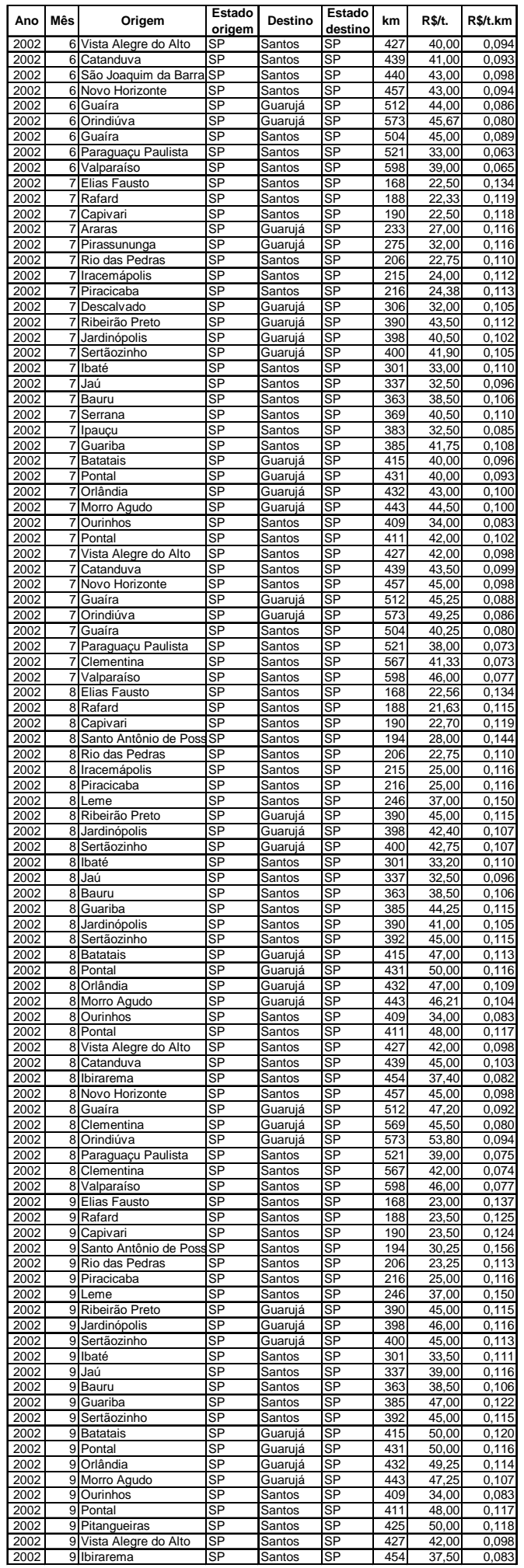

Quadro 16 - Fretes rodoviários para açúcar a granel 


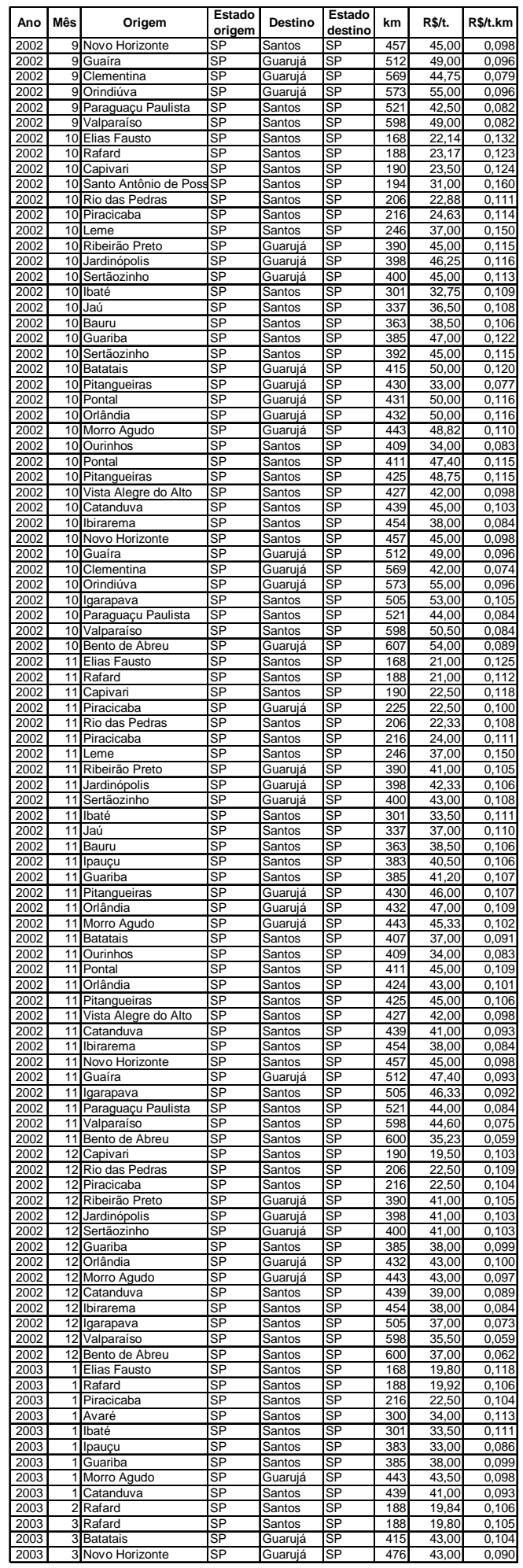

Quadro 16 - Fretes rodoviários para açúcar a granel 


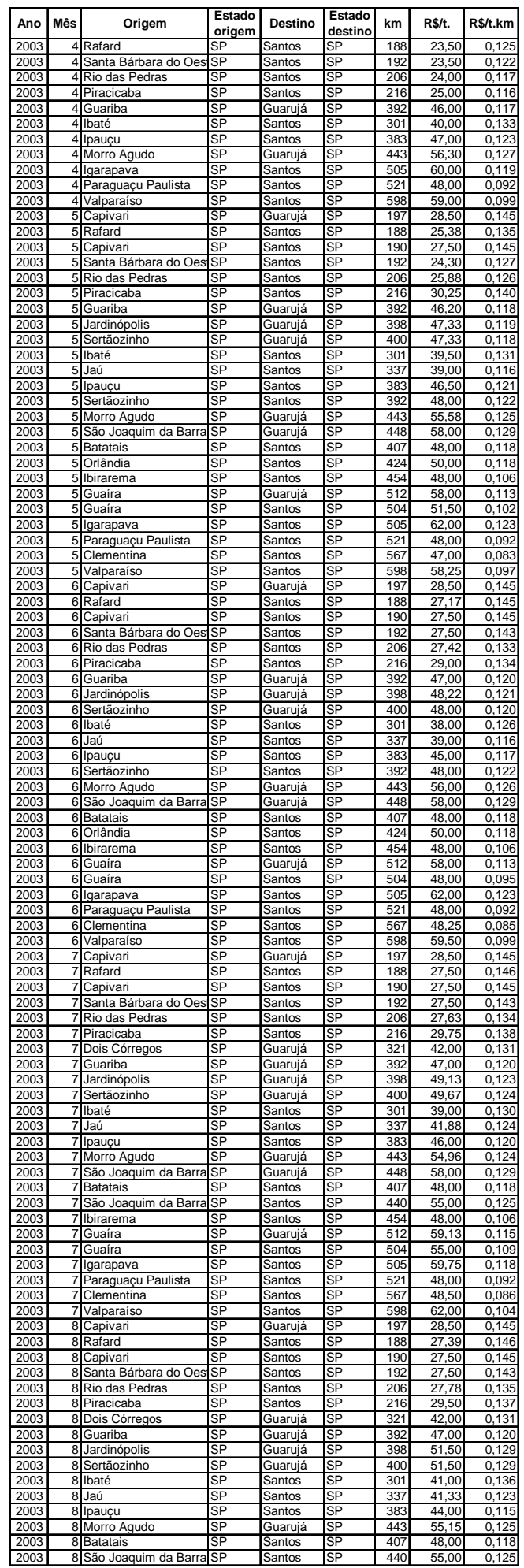

Quadro 16 - Fretes rodoviários para açúcar a granel 


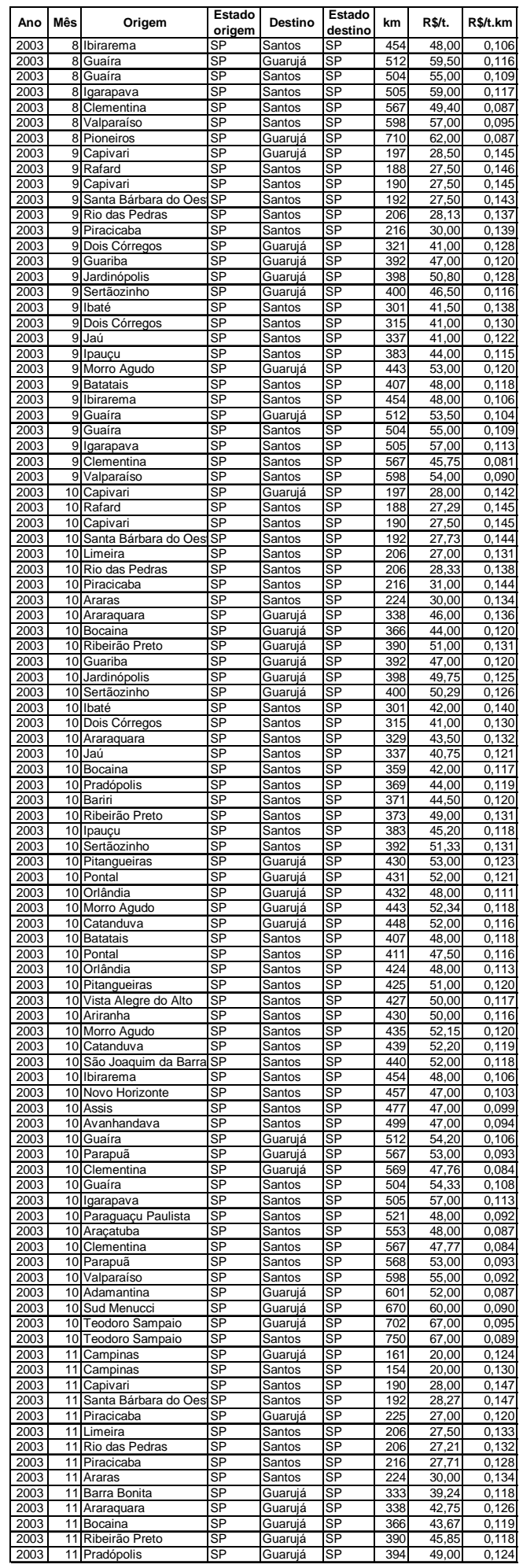

Quadro 16 - Fretes rodoviários para açúcar a granel 


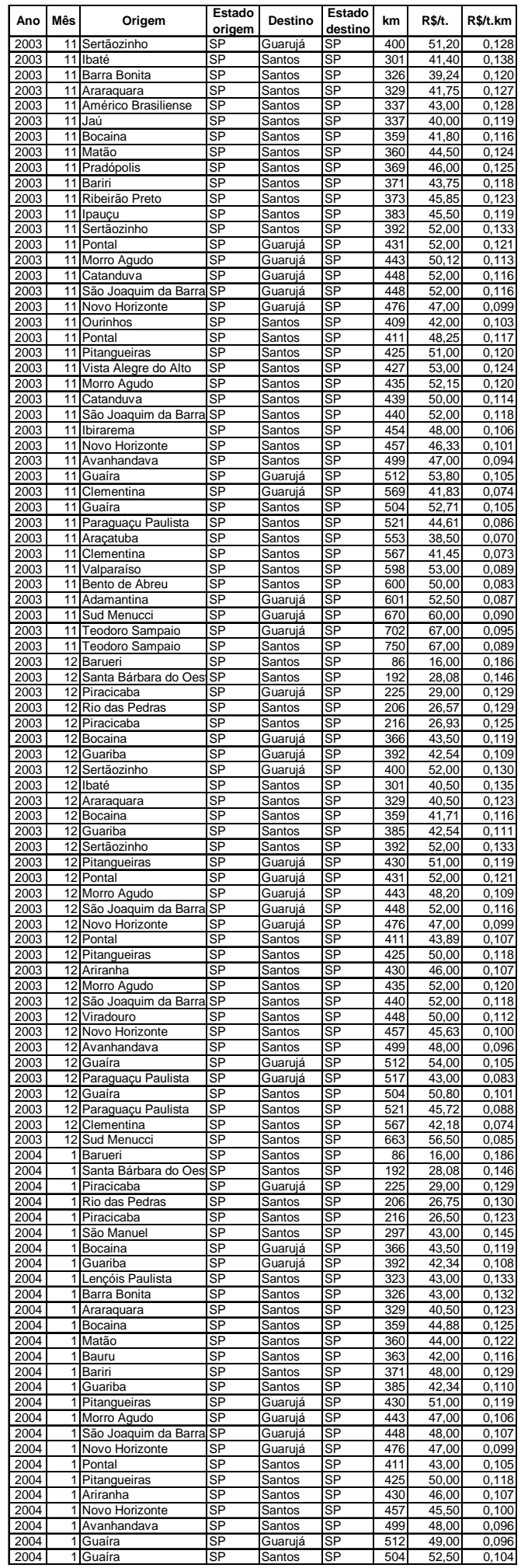

Quadro 16 - Fretes rodoviários para açúcar a granel 


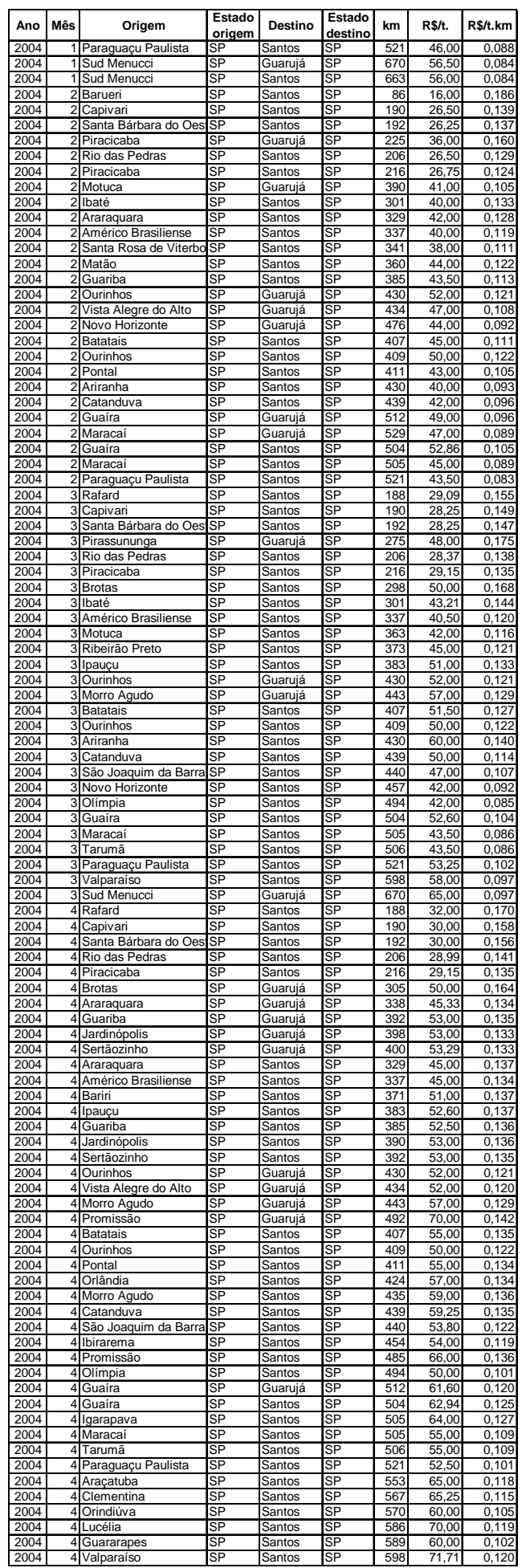

Quadro 16 - Fretes rodoviários para açúcar a granel 


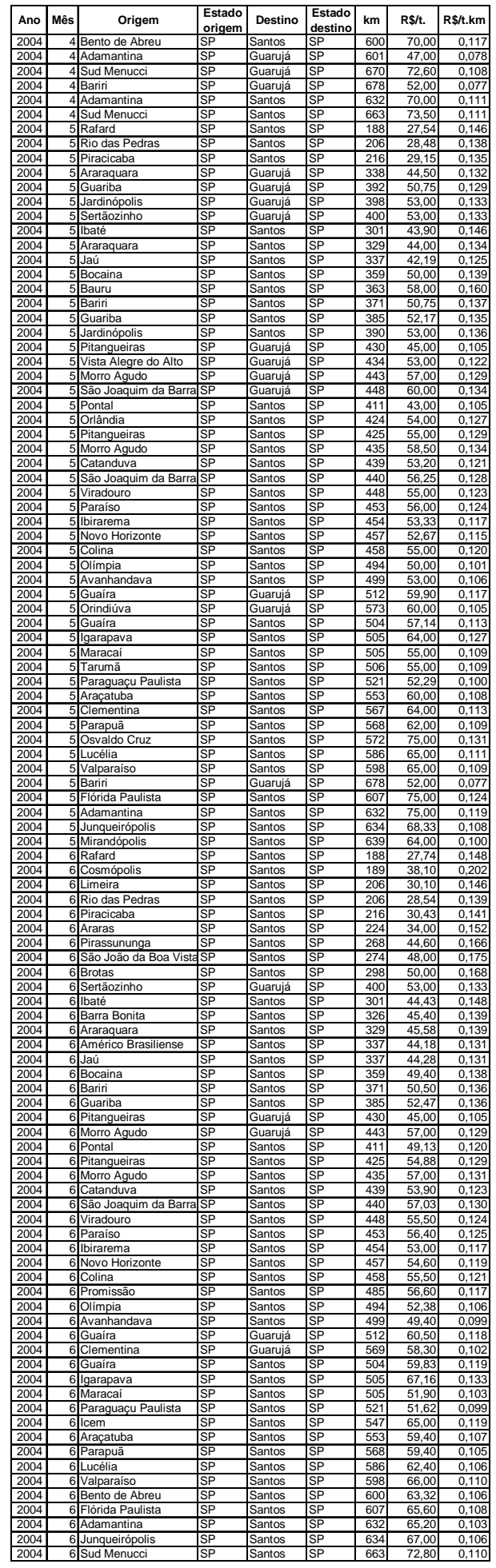

Quadro 16 - Fretes rodoviários para açúcar a granel

Fonte: dados obtidos através do SIFRECA 


\begin{tabular}{|c|c|c|c|c|c|c|c|c|c|}
\hline Ano & Mês & Produto & Origem & & Destino & & km & $\mathrm{R} \$ / \mathrm{t}$. & $\mathrm{R} \$ / \mathrm{t} . \mathrm{km}$ \\
\hline 2002 & 1 & açúcar (granel) & Est. SP & $\mathrm{SP}$ & Est. SP & $\mathrm{SP}$ & 422 & 17,88 & 0,0424 \\
\hline 2002 & 1 & açúcar (granel) & Orlândia & $\mathrm{SP}$ & Guarujá & $\mathrm{SP}$ & 431 & 20,81 & 0,0483 \\
\hline 2002 & 1 & açúcar (granel) & Pitangueiras & $\mathrm{SP}$ & Guarujá & $\mathrm{SP}$ & 557 & 22,00 & 0,0395 \\
\hline 2002 & 2 & çúcar (granel) & Orlândia & $\mathrm{SP}$ & Guarujá & $\mathrm{SP}$ & 431 & 20,81 & 0,0483 \\
\hline 2002 & 2 & cúcar (granel) & Pitangueiras & $\mathrm{SP}$ & Guarujá & SP & 557 & 22,00 & 0,0395 \\
\hline 2002 & 4 & açúcar (granel) & Maringá & $\mathrm{PR}$ & Paranaguá & PR & 497 & 26,00 & 0,0523 \\
\hline 2002 & 5 & açúcar (granel) & Maringá & PR & Paranaguá & PR & 497 & 26,00 & 0,0523 \\
\hline 2002 & 6 & açúcar (granel) & Maringá & PR & Paranaguá & PR & 497 & 25,94 & 0,0522 \\
\hline 2002 & 7 & açúcar (granel) & Maringá & PR & Paranaguá & PR & 497 & 26,78 & 0,0539 \\
\hline 2002 & 8 & açúcar (granel) & Est. SP & $\mathrm{SP}$ & Est. SP & SP & 789 & 30,18 & 0,0383 \\
\hline 2002 & 8 & & & PR & Paranaguá & PR & 497 & 26,78 & \\
\hline 2002 & 9 & çúcar (granel) & SP & SP & \begin{tabular}{|l|} 
Est. SP \\
\end{tabular} & SP & 771 & 29,29 & 0,0380 \\
\hline 2002 & 9 & açúcar (granel) & Maringá & PR & Paranaguá & PR & 497 & 26,78 & 0,0539 \\
\hline 2002 & 10 & açúcar (granel) & Araraquara & $\mathrm{SP}$ & \begin{tabular}{|l|} 
Santos \\
\end{tabular} & $\mathrm{SP}$ & 474 & 18,00 & 0,0380 \\
\hline 2002 & 10 & açúcar (granel) & Est. SP & $\mathrm{SP}$ & Est. SP & $\mathrm{SP}$ & 726 & 29,21 & 0,0402 \\
\hline 2002 & 10 & açúcar (granel) & ingá & PR & Paranaguá & PR & 497 & 26,77 & 0,0539 \\
\hline 2002 & 10 & çúcar (granel) & yueiras & $\mathrm{SP}$ & & SP & 557 & 26,00 & \\
\hline 2002 & 11 & ranel) & Ara & $\mathrm{SP}$ & & $\mathrm{SP}$ & 474 & 18,00 & \\
\hline 2002 & 11 & nel) & & $\mathrm{SP}$ & & $\mathrm{SP}$ & 300 & 25,00 & 333 \\
\hline 2002 & 11 & nel) & & $\mathrm{SP}$ & $\mathrm{SP}$ & $\mathrm{SP}$ & 550 & 26,48 & 0481 \\
\hline 2002 & 11 & açúcar (granel) & ngá & PR & Paranaguá & PR & 497 & 26,77 & 0,0539 \\
\hline 2002 & 12 & açúcar (granel) & quara & $\mathrm{SP}$ & \begin{tabular}{|l|} 
Santos \\
\end{tabular} & $\mathrm{SP}$ & 474 & 20,15 & 0,0425 \\
\hline 2002 & 12 & açúcar (granel) & $\mathrm{SP}$ & SP & Est. SP & $\mathrm{SP}$ & 496 & 26,39 & 0,0532 \\
\hline 2002 & 12 & açúc & & $\mathrm{PR}$ & Paranaguá & PR & 497 & 28,46 & \\
\hline 2002 & 12 & anel) & eiras & SP & rrujá & $\mathrm{SP}$ & 557 & 29,77 & \\
\hline 2003 & 1 & nel) & uara & SP & & $\mathrm{SP}$ & 474 & 20,15 & 425 \\
\hline 2003 & 1 & & & $\mathrm{SP}$ & $\mathrm{SP}$ & SP & 517 & 27,42 & 530 \\
\hline 2003 & 1 & inel) & & PR & רaguá & PR & 497 & 29,39 & 591 \\
\hline 2003 & 1 & $\operatorname{ar}$ (granel) & yueiras & SP & arujá & $\mathrm{SP}$ & 557 & 29,77 & 0,0534 \\
\hline 2003 & 2 & açúcar (gra & & SP & Est. SP & $\mathrm{SP}$ & 517 & 29,64 & 0,0573 \\
\hline 2003 & 2 & nel) & & $\mathrm{PR}$ & naguá & PR & 497 & 29,57 & 595 \\
\hline 2003 & 3 & & & $\mathrm{SP}$ & & SP & 456 & 28,48 & \\
\hline 2003 & 4 & & & PR & aguá & PR & 497 & 36,79 & 740 \\
\hline 2003 & 5 & & & $\mathrm{SP}$ & \begin{tabular}{l|l}
$\mathrm{SP}$ \\
\end{tabular} & $\mathrm{SP}$ & 517 & 29,64 & 5573 \\
\hline 2003 & 5 & nel) & & PR & רaguá & PR & 497 & 36,79 & 0,0740 \\
\hline 2003 & 6 & açúcar (gra & & SP & \begin{tabular}{|l|} 
Est. SP \\
\end{tabular} & $\mathrm{SP}$ & 762 & 33,69 & 0,0442 \\
\hline 2003 & 6 & açúcar (gra & & PR & Paranaguá & PR & 497 & 34,71 & 0,0698 \\
\hline 2003 & 7 & ranel) & & $\mathrm{SP}$ & $\mathrm{SP}$ & $\mathrm{SP}$ & 743 & 33,18 & 0,0447 \\
\hline 2003 & 7 & & & $\overrightarrow{\mathrm{PR}}$ & naguá & PR & 497 & 34,71 & \\
\hline 2003 & 8 & & & $\mathrm{SP}$ & & SP & 744 & 34,53 & \\
\hline 2003 & 8 & & & $\mathrm{PR}$ & laguá & PR & 497 & 34,71 & 0,0698 \\
\hline 2003 & 9 & açúcar (granel) & & SP & \begin{tabular}{l|l}
$\mathrm{SP}$ \\
\end{tabular} & $\mathrm{SP}$ & 688 & 33,94 & 0,0493 \\
\hline 2003 & 9 & açúca & & PR & Paranaguá & PR & 497 & 34,71 & 0,0698 \\
\hline 2003 & 10 & açúcar (granel) & SP & $\mathrm{SP}$ & ESt. SP & SP & 661 & 34,11 & 0,0516 \\
\hline 2003 & 10 & açúcar (g & & PR & Paranaguá & PR & 497 & 34,71 & 0,0698 \\
\hline 2003 & 11 & & & $\mathrm{SP}$ & SP & $\mathrm{SP}$ & 565 & 31,66 & 560 \\
\hline 2003 & 11 & & & PR & Para & PR & 497 & 34,71 & \\
\hline 2003 & 12 & & & $\mathrm{SP}$ & & SP & 545 & 30,97 & 568 \\
\hline 2003 & 12 & nel) & & PR & Paranaguá & PR & 497 & 34,71 & 0,0698 \\
\hline 2004 & 1 & açúcar (g & $\mathrm{SP}$ & SP & \begin{tabular}{|l|} 
Est. SP \\
\end{tabular} & $\mathrm{SP}$ & 478 & 30,16 & 0,0631 \\
\hline 2004 & 1 & açúcar (granel) & ingá & PR & Paranaguá & PR & 497 & 34,71 & 0,0698 \\
\hline 2004 & 2 & açúcar (granel) & SP & SP & \begin{tabular}{|l|} 
Est. SP \\
\end{tabular} & $\mathrm{SP}$ & 499 & 29,03 & 0,0582 \\
\hline 2004 & 2 & & & $\mathrm{PR}$ & naguá & PR & 497 & 34,71 & 0,0698 \\
\hline 2004 & 3 & açúcar (granel) & & $\mathrm{SP}$ & \begin{tabular}{|l|} 
Est. SP \\
\end{tabular} & $\mathrm{SP}$ & 513 & 29,16 & 568 \\
\hline 2004 & 3 & açúcar (granel) & & PR & Paranaguá & PR & 497 & 34,71 & 0,0698 \\
\hline 2004 & 4 & açúcar (granel) & SP & SP & \begin{tabular}{|l|} 
Est. SP \\
\end{tabular} & SP & 506 & 33,89 & 0,0670 \\
\hline 2004 & 4 & açúcar (granel) & Maringá & PR & Paranaguá & PR & 497 & 34,71 & 0,0698 \\
\hline 2004 & 5 & açúcar (granel) & Est. SP & SP & Est. SP & SP & 587 & 35,18 & 0,0599 \\
\hline 2004 & 5 & açúcar (granel) & & $\mathrm{PR}$ & Paranaguá & PR & 497 & 34,71 & 0,0698 \\
\hline 2004 & 6 & açúcar (granel) & & $\mathrm{SP}$ & Est. SP & $\mathrm{SP}$ & 600 & 36,76 & 0,0613 \\
\hline 2004 & 6 & açúcar (granel) & Maringá & $\mathrm{PR}$ & Paranaguá & $\mathrm{PR}$ & 497 & 34,71 & 0,0698 \\
\hline
\end{tabular}

Quadro 17 - Fretes ferroviários para açúcar a granel

Fonte: dados obtidos através do SIFRECA 


\begin{tabular}{|c|c|}
\hline $\begin{array}{c}\text { Distância } \\
(\mathbf{k m})\end{array}$ & Frete (R\$/t) \\
\hline 20 & $\mathrm{R} \$ 3,12$ \\
\hline 20 & $\mathrm{R} \$ 4,17$ \\
\hline 45 & $\mathrm{R} \$ 6,25$ \\
\hline 45 & $\mathrm{R} \$ 6,25$ \\
\hline 50 & $\mathrm{R} \$ 6,25$ \\
\hline 70 & $\mathrm{R} \$ 8,33$ \\
\hline 70 & $\mathrm{R} \$ 7,29$ \\
\hline 80 & $\mathrm{R} \$ 8,33$ \\
\hline 80 & $\mathrm{R} \$ 10,41$ \\
\hline 85 & $\mathrm{R} \$ 8,85$ \\
\hline 90 & $\mathrm{R} \$ 9,37$ \\
\hline 100 & $\mathrm{R} \$ 10,41$ \\
\hline 110 & $\mathrm{R} \$ 11,45$ \\
\hline 120 & $\mathrm{R} \$ 12,50$ \\
\hline 130 & $\mathrm{R} \$ 12,50$ \\
\hline 130 & $\mathrm{R} \$ 13,54$ \\
\hline & \\
\hline
\end{tabular}

Quadro 18 - Fretes de ponta rodoviária cotados e/ou praticados, julho 2004 Fonte: Agentes do mercado 


\section{APÊNDICE 3 - Índices de preço}

Tabela 13. Índices de preço utilizado para levar valores médios de frete para base junho/2004

\begin{tabular}{|c|c|c|c|c|}
\hline Mês & $\begin{array}{l}\text { Preço do Diesel } \\
\text { s/ ICMS }\end{array}$ & $\begin{array}{l}\text { Índice Diesel } \\
\text { (calculado) }\end{array}$ & $\begin{array}{l}\text { Índice IGP- } \\
\text { M }\end{array}$ & $\begin{array}{l}\text { Índice Composto Calculado (70\%IGP- } \\
\text { M, 30\% Diesel) }\end{array}$ \\
\hline $\mathrm{jan} / 02$ & 0,55 & 54,50 & 69,00 & 64,65 \\
\hline $\mathrm{fev} / 02$ & 0,56 & 55,50 & 69,04 & 64,98 \\
\hline $\mathrm{mar} / 02$ & 0,58 & 57,91 & 69,10 & 65,74 \\
\hline $\mathrm{abr} / 02$ & 0,62 & 61,96 & 69,49 & 67,23 \\
\hline mai/02 & 0,64 & 63,56 & 70,06 & 68,11 \\
\hline jun/02 & 0,66 & 65,13 & 71,14 & 69,34 \\
\hline $\mathrm{jul} / 02$ & 0,72 & 71,05 & 72,53 & 72,09 \\
\hline ago/02 & 0,72 & 71,21 & 74,22 & 73,32 \\
\hline set/02 & 0,72 & 71,43 & 76,00 & 74,63 \\
\hline out $/ 02$ & 0,73 & 72,07 & 78,94 & 76,88 \\
\hline nov/02 & 0,87 & 86,22 & 83,04 & 83,99 \\
\hline $\operatorname{dez} / 02$ & 0,96 & 94,82 & 86,15 & 88,75 \\
\hline $\mathrm{jan} / 03$ & 1,05 & 104,23 & 88,15 & 92,98 \\
\hline $\mathrm{fev} / 03$ & 1,06 & 104,75 & 90,17 & 94,54 \\
\hline $\mathrm{mar} / 03$ & 1,06 & 105,10 & 91,55 & 95,61 \\
\hline $\mathrm{abr} / 03$ & 1,04 & 103,67 & 92,40 & 95,78 \\
\hline mai/03 & 0,97 & 96,60 & 92,15 & 93,49 \\
\hline jun/03 & 0,97 & 96,01 & 91,23 & 92,67 \\
\hline jul/03 & 0,97 & 95,93 & 90,85 & 92,37 \\
\hline ago/03 & 0,96 & 95,59 & 91,20 & 92,52 \\
\hline set/03 & 0,96 & 95,62 & 92,27 & 93,28 \\
\hline out $/ 03$ & 0,96 & 95,56 & 92,62 & 93,50 \\
\hline nov/03 & 0,96 & 95,59 & 93,08 & 93,83 \\
\hline $\mathrm{dez} / 03$ & 0,96 & 95,55 & 93,65 & 94,22 \\
\hline $\mathrm{jan} / 04$ & 0,96 & 95,60 & 94,47 & 94,81 \\
\hline $\mathrm{fev} / 04$ & 0,97 & 95,87 & 95,13 & 95,35 \\
\hline $\mathrm{mar} / 04$ & 0,97 & 95,99 & 96,20 & 96,14 \\
\hline $\mathrm{abr} / 04$ & 0,97 & 96,01 & 97,37 & 96,96 \\
\hline mai/04 & 0,97 & 95,99 & 98,64 & 97,85 \\
\hline jun/04 & 1,01 & 100,00 & 100,00 & 100,00 \\
\hline
\end{tabular}

Fonte: elaborado a partir de dados da ANP e do IPEA 